\title{
HABITAÇÃO VERTICAL PRIVADA E 0 MERCADO IMOBILIÁRIO EM SÃO PAULO: Dois Períodos, Dois Casos Dissidentes I Formaespaço e Idea!Zarvos
}

\author{
Priscylla Nose de Lima
}

Dissertação de mestrado apresentada à Faculdade de Arquitetura e Urbanismo da Universidade de São Paulo para obtenção do título de Mestre

Área de Concentração: Projeto de Arquitetura

Orientador: Prof. Dr. Francisco Spadoni 
AUTORIZO A REPRODUÇÃO E DIVULGAÇÃO TOTAL OU PARCIAL DESTE TRABALHO, POR QUALQUER MEIO CONVENCIONAL OU ELETRÔNICO, PARA FINS DE ESTUDO E PESQUISA, DESDE QUE CITADA A FONTE.

E-MAIL: limapri@uol.com.br

Lima, Priscylla Nose de

L732h Habitação vertical privada e o mercado imobiliário em

São Paulo: dois períodos, dois casos dissidentes Formaespaço e Idea!Zarvos / Priscylla Nose de Lima. - - São Paulo,

2013.

240 p.: il.

Dissertação (Mestrado - Área de Concentração: Projeto de Arquitetura) - FAUUSP.

Orientador: Francisco Spadoni

1.Edifícios residenciais - São Paulo (SP) 2.Mercado

imobiliário - São Paulo (SP) 3.Formaespaço 4.Idea!Zarvos

I.Título

CDU 728(816.11) 


\section{AGRADECIMENTOS}

Ao Francisco Spadoni, meu orientador, pelo constante apoio e incentivo.

Aos professores Helena A. Ayoub Silva e Luís Antonio Jorge pelos comentários durante o exame de qualificação.

Aos arquitetos João Sodré e Guillaume Sibaud, pelas entrevistas, esclarecimentos e informações.

Ao Fabrício Augusto Gomes Pereira e seus colegas do Secovi pela atenção e prontidão.

Ao arquiteto Fernando Serapião por sua atenção, sugestões e esclarecedores dados.

Aos bibliotecários pelo cuidado em auxiliar nas incessantes buscas.

À secretaria da pós-graduação da FAU USP.

Aos queridos amigos e familiares pelo apoio incondicional e paciência durante o longo período de elaboração deste trabalho, além da compreensão de minha ausência. 

da história; entre as décadas de 60 e 70 do século 20 e a primeira década do século 21 . Dois períodos que apresentaram propostas de destaque dentro do mercado imobiliário mostrando um novo olhar frente à produção da arquitetura. Examinar além dos aspectos conceituais que os definiram como obras singulares no conjunto da produção imobiliária privada, quais seriam os aspectos estruturais que estariam por trás desta iniciativa: quem são seus agentes, quais as motivações financeiras e eventuais aspectos culturais que definiriam uma nova perspectiva sobre a produção desta arquitetura.

Os aspectos a serem considerados para a análise e avaliação dos resultados, referem-se não só a estrutura de linguagem renovadora, mas também sobre outras eventuais conquistas relativas à reconfiguração da espacialidade, flexibilidade de plantas, pesquisas tecnológicas e aspectos sociofinanceiros da operação: publico consumidor, interesse mercadológico, incorporador, etc.

Palavras - chave: São Paulo, Habitação Privada, Mercado Imobiliário, Formaespaço, Idea!Zarvos 


\section{ABSTRACT}

To study the production of private residential buildings in the city of São Paulo in two different time periods, first between the 60's and 70's of the 20th century; and the first decade of the 21st century. Two distinct periods with above average proposals within the real estate market reflecting the contemporary architectonic production. To exam not the only conceptual aspects that have defined them as unique in the whole of the privately built real estate; but also the structural aspects that might be behind this initiative: who are their agents, what financial motivations they had, and the eventual cultural aspects that have defined a new perspective on the production of this architecture.

The aspects to be considered in this analysis and evaluation of results refer both to the innovative structural language, and to the eventual advancements related to spatial reconfiguration, flexibility of blue prints - layout flexibility, technological research as well as social and economic aspects of the project: end consumers, market interest, development, etc.

Keywords: Sao Paulo, Private Housing, Real Estate Market, Formaespaço, Idea!Zarvos. 
SUMÁRIO

08

1. Introdução

11

12

16

20

22

30

60

78

\section{Primeiro Período I 1963 - 1973}

2.1. A produção de apartamentos em São Paulo nos Anos 60 e 70 sob a influência da Escola Paulista de Arquitetura

2.2. Os edifícios de habitação nos Anos 60

2.3. São Paulo e o PDDI - Plano Diretor de Desenvolvimento Integrado

2.4. A Construtora Formaespaço

2.5. Formaespaço e o arquiteto Abrahão Sanovicz

2.6. Formaespaço e o arquiteto Eduardo de Almeida

2.7. Formaespaço e o arquiteto Paulo Mendes da Rocha 


\section{Segundo Período I 2000 - 2010}

3.1. A produção de apartamentos em São Paulo na primeira década do século 21

3.2. São Paulo e o PDE - Plano Diretor Estratégico

3.3. O Caso Zarvos

3.4. Idea!Zarvos e o escritório Andrade Morettin

3.5. Idea!Zarvos e o escritório Triptyque

3.6. Idea!Zarvos e o escritório Grupo SP

\section{Considerações Finais}

Bibliografia 


\section{INTRODUÇÃO}

Este trabalho se propõe a estudar a produção de edifícios residenciais verticais privados na cidade de São Paulo em dois momentos da história - entre as décadas de 60 e 70 do século 20 e a primeira década do século 21. Dois períodos que apresentaram propostas de destaque dentro do mercado imobiliário mostrando em comum, um novo olhar frente à produção da arquitetura.

Inicialmente, foram selecionados como objeto de pesquisa, os edifícios produzidos pela incorporadora Idea!Zarvos entre os anos de 2000 e 2010. Porém, ao investigar os antecedentes deste mercado, notouse que a construtora Formaespaço, em um momento anterior, também elegeu a arquitetura de repertório como estratégia de venda.

Sendo assim, o estudo caminhou para uma análise paralela destas duas iniciativas tendo como objetivos pretendidos, explorar os aspectos conceituais que os definiram como obras singulares no conjunto da produção imobiliária privada, além de analisar os aspectos estruturais que estariam por trás desta iniciativa: seus agentes, quais as motivações financeiras e eventuais aspectos culturais que definiriam uma nova perspectiva sobre a produção desta arquitetura nos dois recortes de tempo selecionados.

A construtora Formaespaço, respondendo à situação socioeconômica estabelecida na época, idealiza projetos de edifício de habitação privados com a possibilidade de serem produzidos em série e implantados em lotes disponíveis, principalmente na cidade de São Paulo. As obras da construtora refletem, por um lado, a postura dos profissionais envolvidos e, por outro lado, o período favorável à produção da moradia que se configurou a partir da criação do BNH - Banco Nacional da Habitação. 
Dentro dessas premissas, ganharam destaque os projetos dos edifícios Modulares, do arquiteto Abrahão Sanovicz, edifícios Gemini, Lark e Coronet, do arquiteto Eduardo de Almeida e edifícios Protótipo [não executado] e Clermont, do arquiteto Paulo Mendes da Rocha.

A incorporadora Idea!Zarvos, também respondendo à situação socioeconômica e de legislação atual, idealiza projetos de habitação privada, porém em contrapartida ao principal argumento da Formaespaço que produziu edifícios em série, realiza hoje, edifícios exclusivos. O critério para a seleção das obras foi verificar primeiramente, dentro do período em questão, quais obras já haviam sido realizadas ou então, que estivessem com a construção em andamento. A partir daí, escolheu-se três escritórios de arquitetura para análise - Andrade Morettin com os edifícios Aimberê 1749 e Fidalga 772, Triptyque com o edifício Fidalga 727 e Grupo SP com os edifícios Simpatia 236 e Itacolomi 445.

Não é objetivo deste trabalho percorrer a história da arquitetura paulista e nem abordar toda a obra dos arquitetos selecionados. O estudo se restringe na análise de obras específicas e limita-se a apontar similaridades e divergências nas produções de cada período sobre um problema comum que é a utilização de uma arquitetura de repertório como estratégia de venda.

Sua estrutura foi dividida em duas partes, correspondentes aos dois períodos de tempo em análise.

No primeiro recorte, temos como mote o trabalho desenvolvido pela construtora Formaespaço e no segundo, o trabalho desenvolvido pela incorporadora Idea!Zarvos. 
Um panorama da produção habitacional vertical privada vigente em cada época, assim como a legislação corrente são expostos como apoio à compreensão dos períodos. Por fim, uma breve apresentação dos arquitetos e a análise das obras.

Para esta composição, foram realizadas pesquisas bibliográficas, entrevistas e redesenho das obras selecionadas. Estas informações comparecem em grande parte, contidas no texto e nas ilustrações, conformando o trabalho em si. 
2. PRIMEIRO PERÍODO I 1963 - 1973 


\subsection{A PRODUÇÃO DE}

APARTAMENTOS EM SÃO

PAULO NOS ANOS 60 E 70

SOB A INFLUÊNCIA DA ESCOLA

PAULISTA DE ARQUITETURA
A arquitetura em São Paulo nas décadas de 1960 e 1970 foi marcada principalmente pela racionalização construtiva, tendo a estrutura como protagonista da forma.

Os edifícios deste período, analisados neste trabalho, contemplam duas das principais linhas de pesquisa desenvolvidas pelos arquitetos paulistas nos anos 60 e 70. A primeira refere-se à pesquisa estética realizada em meados dos anos 50 , caracterizada pelo uso intenso do concreto aparente, cujo conjunto construído posteriormente foi definido como pertencente à Escola Paulista de Arquitetura. A segunda linha trata da tentativa de conciliação dos sistemas tradicionais de construção com as possibilidades industriais do mercado, ou seja, entender o processo de construção como montagem, agregando novos materiais industriais com o objetivo de redução do tempo de obra. Esta pesquisa foi intensificada após a criação do BNH - Banco Nacional da Habitação, que vinculará a redução de prazos das obras aos prazos do financiamento.

Historicamente o início da Escola Paulista está ligado a uma revisão formal realizada por Vilanova Artigas que tem como marco a residência Olga Baeta [Figura 1], primeira obra a concretizar os conceitos éticos e estéticos da nova arquitetura.

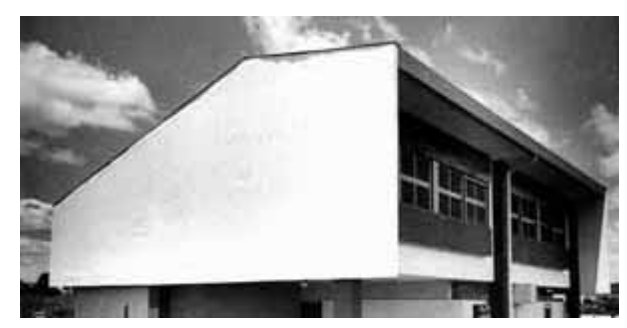

Figura 1 - Residência Olga Baeta, São Paulo - 1956 
Deve-se ter em conta também, o momento político e econômico presente em meados dos anos 50 e 60 . A política econômica desenvolvida no período de Juscelino Kubistchek [1956 - 1961] estimulou a vinda de inúmeras empresas multinacionais e a criação de um complexo de indústrias de base que forneceria os bens de produção necessários à futura expansão industrial. Esta grande onda de desenvolvimento fez a maioria acreditar que os problemas da sociedade brasileira seriam passageiros. Entretanto, Kubistchek deixa de herança uma grave crise econômica ao seu sucessor Jânio Quadros, que sem estrutura, renuncia ao cargo em favor do vice-presidente João Goulart, figura reconhecidamente de esquerda. O apoio governamental às constantes greves por aumentos salariais e a tentativa de implantar reformas sociais de base, aliado à crise econômica, criou o cenário político propício ao golpe militar, efetivamente realizado em março de 1964.

Neste ambiente, deu-se início a revisão formal da arquitetura em São Paulo, estimulada pelo grande desenvolvimento econômico e pelo forte ideal nacionalista gerado nos governos de Kubistchek e Goulart. Esta revisão partiu de um questionamento do modelo gerador da Escola Carioca frente às reais condições da sociedade brasileira. Indagava-se a suposta validade do modelo de Arquitetura Internacional para qualquer contexto, revisando os preceitos da Escola Carioca que ao chegar a São Paulo, derivam para questões éticas e estéticas.

Ao questionar o verdadeiro significado de uma arquitetura social, conclui-se que esta não era uma arquitetura de luxo, de acabamentos refinados e derivada do padrão de vida burguês. 
Diante da realidade da mão-de-obra disponível e da real e imediata viabilidade da industrialização do setor civil, constata-se que a tecnologia do concreto armado era a mais desenvolvida e assimilada entre as técnicas tradicionais, além de ser um material de baixo custo. Assim, os arquitetos desenvolvem um raciocínio estrutural procurando explorar o desenvolvimento desta tecnologia em seu limite.

A linguagem desenvolvida pelo grupo ligado a Artigas está coligada a um conjunto de estratégias compositivas eleitas em primeira mão e derivadas do repertório moderno. São dois os principais conceitos geradores de forma exterior do edifício: o prisma elevado sobre pilotis e o grande abrigo, ou seja, uma grande cobertura que pode alcançar ou não os limites laterais do lote urbano. Optar por uma solução formal inicial, da qual as demais etapas de projeto se tornam subordinadas, resolvendo problemas compositivos e detalhes desta opção feita no primeiro momento do projeto, caracteriza boa parte das obras filiadas à Escola Paulista.

A corrente brutalista, outra denominação dada à Escola Paulista, influenciou inúmeras obras paulistanas, como também obras em outras capitais do país, sendo empregada em diversos edifícios públicos como fóruns, escolas, postos de saúde, bancos, etc.; porém, seu emprego em prédios habitacionais coletivos foi restrito por não se enquadrar no gosto médio do público, acostumado ao acabamento tradicional nas residências. 
O fato foi observado no Edifício Guaimbê [Figura 2], projetado pelo arquiteto Paulo Mendes da Rocha e Eduardo de Gennaro, inteiramente em concreto aparente. LEMOS afirma:

Vários proprietários de unidades autônomas transformaram radicalmente o aspecto interno das mesmas. A dificuldade em aceitar que apartamentos de excelente padrão apresentem aspecto "inacabado", levou mesmo alguns a considerar a possibilidade de transformação das áreas de uso comum, através de seu total revestimento ${ }^{1}$.

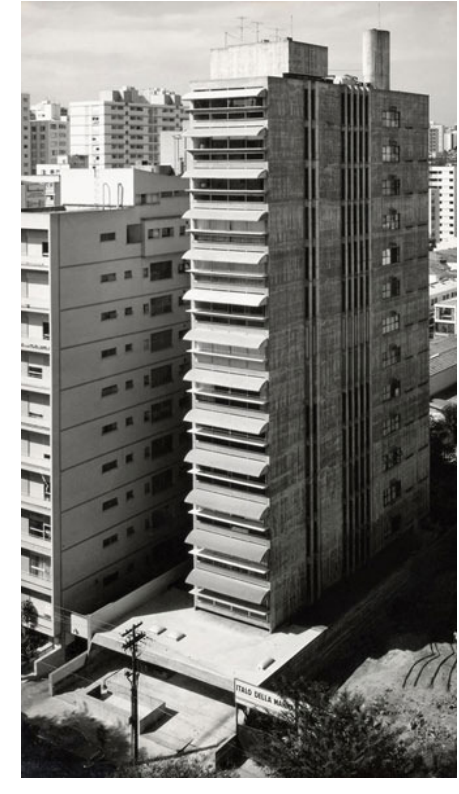

Figura 2 - Edifício Guaimbê, São Paulo - 1962

Fonte: Revista Acrópole - Setembro 1967

${ }^{1}$ LEMOS, Carlos - "As raízes são culturais" in O Dirigente Construtor. P 48. São Paulo, 1965. 


\subsection{OS EDIFÍCIOS DE HABITAÇÃO} NOS ANOS 60
Nos anos 60, confirma-se a tendência à monofuncionalidade dos edifícios residenciais, praticamente desaparecendo a ocupação do nível térreo com atividades comerciais. A legislação municipal determina recuos maiores e o mercado imobiliário favorável à tipologia da torre isolada, reforçaram este tipo de modelo.

Na pretensão de uma maior monumentalidade, os edifícios eram implantados com grandes afastamentos frontais, apesar dos recuos laterais não serem tão generosos. Como consequência, as grandes áreas livres voltadas ao acesso principal, eram tratadas com um exuberante paisagismo de caráter decorativo, apresentando eventualmente play-ground, disposto na lateral ou fundo do lote. Difundiu-se a solução de garagens em subsolo, prevendo-se ao menos uma vaga para cada unidade, liberando o térreo desta função. O térreo abrigava o apartamento do zelador e portaria, hall social e salão de festas; os acessos eram muito bem definidos.

Apesar do hall social ser separado fisicamente do hall de serviços, procurou-se interligá-los por questões de segurança. Devido ao pequeno número de unidades habitacionais presentes mesmo nas torres mais altas, os edifícios dispunham apenas de dois elevadores e não raro o hall social era decorado com um painel / mural realizado por artista plástico.

A grande metragem dos apartamentos então praticados pelo mercado imobiliário e "exigidos" pelas normas legais limitou a variação tipológica de unidades, com no máximo duas unidades diferenciadas. 
O programa interno não apresentou mudanças significativas às praticadas nos anos 50, somente alguma sofisticação do programa induzido em parte pelas enormes áreas atingidas nos apartamentos: lavabo social e suíte tornaram-se itens indispensáveis. Acentua-se a separação física entre cozinha e copa, as áreas de serviço passam a abrigar além do tanque, espaço para a máquina de lavar roupa. Muitas unidades já vinham equipadas com armários embutidos; materiais nobres como mármore e madeira de lei decoravam as áreas sociais e circulações comuns; diferenciais que reforçavam o "status" de forma a atrair a classe média para o empreendimento.

As fachadas se modernizaram. Os edifícios passam a ter, em sua maioria, a estrutura modelada e ordenada, sendo este o maior elemento plástico da composição. A expressão plástica pela estrutura foi sendo mais utilizada conforme se divulgava a ideologia da Escola Paulista entre os arquitetos. A estrutura então se torna mais arrojada e em certos casos, os pilotis são substituídos pelos grandes vãos livres obtidos com as novas tecnologias. As esquadrias, padronizadas, tenderam à homogeneização, fixadas entre os vãos da estrutura. Prioriza-se também a concentração das prumadas hidráulicas sempre que possível, resultando em soluções de plantas extremamente organizadas do ponto de vista construtivo.

A grave crise econômica que assolou o país entre 1962 e 1967 não afetou o mercado imobiliário que só cresceu durante toda a década. O crescimento vertical, praticamente saturado na área central, atingiu 
nesta época 29 bairros $^{2}$, decorrente da limitação do aproveitamento dos terrenos urbanos impostos pela Lei $5.261 / 57$ e do crescente uso do automóvel. Esta lei, que condicionava à construção de apartamentos com grande metragem aliada a retração da demanda das classes de menor renda provocada pela recessão econômica do período determinou que o processo de incorporação pelo preço de custo se direcionasse as classes média e média - alta. Conforme aponta VILARIÑO, houve um crescimento da área vertical aprovada, apesar do número de edificações se manter estável, ou seja, no período construíram-se apartamentos de maior metragem.

Os incorporadores burlavam a lei, aprovando os apartamentos como consultórios para utilizar o coeficiente de aproveitamento igual a seis, índice 50\% maior que o permitido para edifícios residenciais. Com a criação do BNH em 1964, este artifício deixa de ser utilizado, pois o banco só financiava edifícios habitacionais. Diante da grande pressão imposta pelo mercado imobiliário, o então prefeito Faria Lima, aprova a Lei 6.877 em 1966 que equaliza os coeficientes de aproveitamento em seis tanto para os edifícios comerciais como residenciais. Também se revogou a norma que definia o pé-direito mínimo de 2,70 metros para dormitórios, e o mercado imobiliário passou a adotar 2,50 metros para obter um número maior de andares frente aos gabaritos exigidos por lei.

${ }^{2}$ Bela Vista e Cerqueira Cesar são os que mais verticalizam. Santa Cecilia, Bom Retiro, Higienópolis, Campos Elíseos, Pinheiros, Vila Buarque, Vila Mariana, Paraíso, Aclimação, Consolação, Liberdade, Jardim Paulista, Mooca, Perdizes, Brooklin, Cambuci, Santa Ifigênia e Santana. No Brás, Ipiranga, Jardim Europa, Jabaquara, Lapa, Saúde, Vila Nova Conceição e Itaim a verticalização ainda era incipiente. A maioria desses bairros localizava-se na zona sudoeste da cidade, tradicionalmente conhecida pelo setor ocupado pelas classes mais altas da cidade. Dados extraídos da dissertação de mestrado VILARIÑO, Maria do Carmo - "Habitação Verticalizada na Cidade de São Paulo dos anos 30 aos anos 80. Investigação acerca da contribuição dos arquitetos modernos ao tema. Estudos de Caso". FAU-USP. São Paulo, 2000. 
Apesar da legislação municipal não induzir mais a construção de grandes apartamentos, o mercado imobiliário continuou a atender os setores de alta renda, pois com a criação do BNH, o empresariado vislumbrou a possibilidade de conseguir empréstimos para construir sem ter que colocar seus recursos próprios, e depois, repassar a dívida aos compradores. Com facilidade para conseguir financiamentos com prestações mais econômicas que as do aluguel, a classe média buscou imóveis mais luxuosos, abandonando o processo de adquirir a moradia com recursos próprios, típico da década anterior.

Neste período surge também a propaganda imobiliária, novidade que rapidamente se popularizou na cidade. Os stands, antes mais parecidos com barracões de obra, passam a ser decorados por arquitetos, apresentando plantas, maquetes e impressos bem elaborados e coloridos, divulgando o empreendimento. Segundo VILARIÑO, o início pioneiro desse tipo de propaganda pode ser atribuído à VEPLAN - Indústria Imobiliária de São Paulo Ltda., que iniciou suas promoções imobiliárias na cidade em 1963. 


\subsection{SÃO PAULO E O PDDI \\ PLANO DIRETOR DE \\ DESENVOLVIMENTO \\ INTEGRADO}

A cidade de São Paulo sempre foi apresentada ao país como um exemplo de grandeza, tendo seu desenvolvimento e crescimento desordenado e caótico entendido como fruto passageiro de seu processo de modernização. Porém, no início dos anos 70, quando se percebeu o aumento dos problemas sociais e que não era possível oferecer os serviços urbanos na velocidade requerida, o discurso mudou. O urbano passa a ser um problema.

A capital paulista nunca teve um plano diretor que regulasse seu desenvolvimento. Todas as tentativas feitas, mesmo o plano de Avenidas de Prestes Maia, vieram sempre com atraso, remediando uma situação há muito superada no momento de sua realização.

A mudança nas condições políticas após o golpe de 1964 favoreceu a intensificação da atividade do planejamento urbano e da proposição de novas legislações urbanísticas, à medida que interrompeu os canais de reivindicação popular, possibilitando que as propostas técnicas se realizassem sem o comprometimento político de atender as demandas sociais.

A idéia de limitar o crescimento da cidade ganha força e em 1971, na gestão do prefeito Figueiredo Ferraz, foi aprovado o PDDI - Plano Diretor de Desenvolvimento Integrado, que instituiu diretrizes de desenvolvimento urbano, definiu oito zonas de uso com diferentes características nos índices e taxas construtivas permitidas e reduziu o coeficiente de aproveitamento máximo do lote de seis para quatro, índice atingido em poucas zona somente, com restrições ainda maiores para o resto da cidade. 
A iminência da aprovação da Lei de Zoneamento, que confirmou as proposições presentes no PDDI, provocou uma aprovação antecipada de inúmeros empreendimentos habitacionais para garantir os maiores índices de aproveitamento presentes na lei anterior. Esses edifícios, construídos e comercializados até aproximadamente 1975, fizeram com que a produção do período apresentasse as mesmas características das edificações dos anos 60. 


\subsection{A CONSTRUTORA}

FORMAESPAÇO
Inserido neste contexto, surge em 1963 com uma produção de pouca expressão, a construtora Formaespaço. No ano de 1968, respondendo à situação socioeconômica estabelecida, a Formaespaço passa a idealizar projetos de edifício de habitação privados com a possibilidade de serem produzidos em série e implantados em lotes disponíveis, principalmente na cidade de São Paulo.

As obras da construtora passam a refletir, por um lado, a postura dos profissionais envolvidos e, por outro lado, o período favorável à produção da moradia que se configurou a partir da criação do BNH.

Assim, dentro do programa da construtora, ganharam destaque obras de arquitetos como Abrahão Sanovicz com o projeto dos Edifícios Modulares, Eduardo de Almeida com o projeto do Edifício Gemini e Paulo Mendes da Rocha que projetou o Protótipo, que não chegou a ser executado. Os arquitetos Fábio Penteado, Fleury de Oliveira e Ennes Silveira Mello também chegaram a participar dos projetos da construtora, mas num período menos favorável e já de comprometimento financeiro da mesma. Segundo a análise de IMBRONITO, esta característica peculiar da construtora em reproduzir seus edifícios, nos faz considerar o grau de reflexão contido nos projetos, abrindo duas vertentes de valor:

A primeira aponta em o que há de comum entre os edifícios, referindo-se não apenas a programas práticos aos quais os projetos buscaram responder, mas também à semelhança de pensamentos sintonizados com o ambiente arquitetônico e cultural no qual estão inseridos.

A segunda diz respeito às soluções individuais assumidas por cada arquiteto em seu projeto, aproximando as metodologias e identificando aspectos que possam contribuir para configurar uma 
variável do pensamento de cada um deles sobre o tema da habitação e, de modo mais amplo, sua arquitetura ${ }^{3}$.

Como já citado, com a criação do BNH em agosto de 1964, rapidamente, organizou-se uma estrutura nacional de captação e agenciamento de recursos para financiamento de habitação. Inicialmente o Banco dedicou-se à habitação social e dispôs de poucos recursos, captados principalmente a partir de uma dedução da folha de pagamento. A partir de 1967, com a criação do FGTS [Fundo de Garantia do Tempo de Serviço] e o incentivo dado às cadernetas de poupança, definiu-se o quadro propício à produção de edifícios habitacionais para a classe média. Com o FGTS, a arrecadação do Banco aumentou cerca de nove vezes. Por outro lado, houve um redirecionamento na aplicação destes recursos, que foram priorizados para a classe média, em detrimento da habitação de interesse social Alia-se a este fato o incremento do poder de compra da classe média nos anos 70, devido ao milagre econômico brasileiro. Estes fatores levaram a uma disseminação do número de empreendimentos, fase que durou até meados de 1974, momento em que novos rumos foram tomados pelo BNH, cujos recursos foram redirecionados à habitação social ou destinados a projetos de infraestrutura ${ }^{4}$.

Houve então repentinamente, no final dos anos 60, um grande volume de dinheiro disponibilizado para os investidores e construtores do setor privado. Este período coincide, em São Paulo, a um momento

\footnotetext{
${ }^{3}$ Dados extraídos da dissertação de mestrado IMBRONITO, Maria Isabel - "Três Edifícios de Habitação para a Formaespaço: Modulares, Gemini e Protótipo". FAU-USP. São Paulo, 2003.

${ }^{4}$ Dados extraídos da dissertação de mestrado VILARIÑO, Maria do Carmo - "Habitação Verticalizada na Cidade de São Paulo dos anos 30 aos anos 80. Investigação acerca da contribuição dos arquitetos modernos ao tema. Estudos de Caso”. FAU-USP. São Paulo, 2000
} 
também favorável da legislação. Foi em 1966 que o prefeito Faria Lima com a Lei 6.877 aumentou o coeficiente de aproveitamento em habitação para seis na cidade. Mas foi a eminente aprovação da Lei de Zoneamento de 1972, que reduziu drasticamente o coeficiente de aproveitamento na cidade, e gerou uma corrida para a aprovação de projetos com base na lei anterior, para que pudessem ainda valer os benefícios desta lei. A Lei de Zoneamento [Lei 7.085] de 1972 estabeleceu zonas diferentes para a cidade e, de modo geral, restringiu os coeficientes de aproveitamento. Isto gerou uma demanda por terras urbanas e a verticalização em áreas periféricas, em terrenos afastados e vazios.

Agentes, incorporadores e construtores tiveram que se adaptar rapidamente a esta situação, inaugurando novas maneiras de produzir habitação. O alto custo financeiro do capital tornou necessário acelerar o processo de projeto e obra, pois somente o rápido retorno do empreendimento traria a vantagem financeira da operação. Para viabilizar este processo e agilizar a produção, alguns construtores utilizaram projetos-padrão.

Algumas construtoras elaboraram ou contrataram projetos de edifícios para serem executados repetidamente, em diversos terrenos disponíveis na cidade, em bairros localizados nas zonas de crescimento da classe média. Por terem que se adaptar aos índices urbanísticos e ao terreno, estes edifícios apresentaram variação em sua implantação, térreo, garagem e número de pavimentos. Quando implantados em terrenos maiores são dispostos agrupados, formando conjuntos. Porém a estrutura, planta do andar tipo, materiais e detalhamentos variam pouco de um edifício para outro. Segundo depoimentos extraídos no trabalho de IMBRONITO, a primeira construtora a se organizar para a produção em série, com a velocidade e agilidade necessárias para corresponder às exigências do BNH e atender à demanda de mercado foi a Hindi. O objetivo era que estivesse pronto em 210 dias. 
O projeto-padrão permite economia de tempo tanto na fase de projeto quanto na fase de construção. Torna possível um maior planejamento da obra, controles mais eficazes de custos, armazenamento de materiais e até mesmo a produção própria de determinados componentes da construção. Entretanto, poucos foram os resultados para inovar a produção no sentido da industrialização. O sistema construtivo utilizado para a racionalização da construção foi chamado tradicional evoluído ${ }^{5}$, a com a introdução de alguns processos mecanizados ao sistema tradicional.

\section{ESTRATÉGIA DE ATUAÇÃO}

A Formaespaço se aproveitou desta situação gerada a partir do BNH. Entretanto, diferentemente de outras construtoras, utilizou características da arquitetura para organizar sua produção. A arquitetura comparece com clareza em seus aspectos construtivos, com volumetrias simplificadas, modulação estrutural, materiais aparentes e componentes padronizados. Trata-se de uma linguagem cujo desenho nasce comprometido com a maneira pela qual se executa.

Ao mesmo tempo em que esta arquitetura não correspondia a certos preceitos estabelecidos pelo mercado imobiliário, foi utilizada como estratégia de venda. A Formaespaço assumiu a imagem de inovação e modernidade. As inovações não se restringiram aos edifícios e à forma de produção.

${ }^{5}$ Dados extraídos da entrevista com o arquiteto João Honório de Mello Filho, para a dissertação de mestrado IMBRONITO, Maria Isabel - “Três Edifícios de Habitação para a Formaespaço: Modulares, Gemini e Protótipo". FAU-USP. São Paulo, 2003. 
Como dito, estavam também presentes na divulgação, nos stands, reportagens e folhetos publicitários, e na exposição do apartamento mobiliado [Figuras 3 e 4]

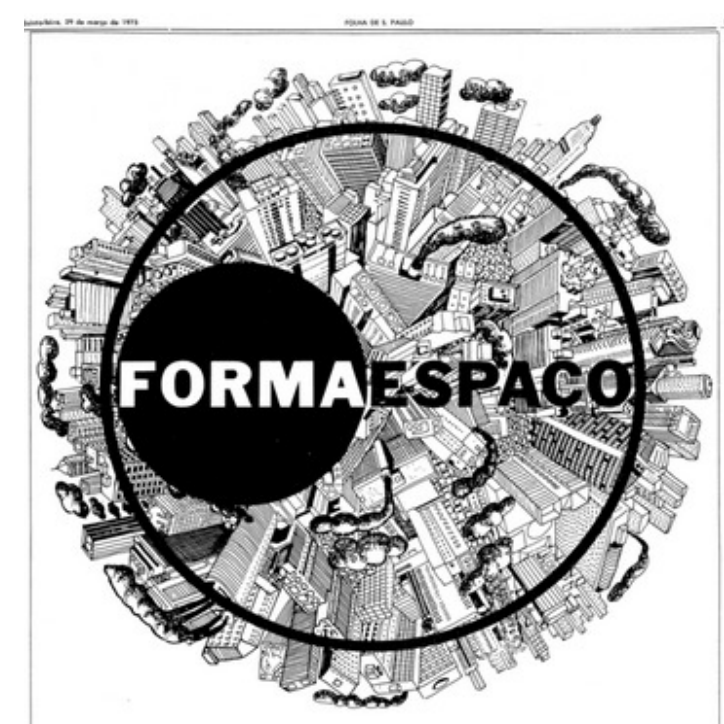

Vamos mudar a imagem negativa da nossa cidade.

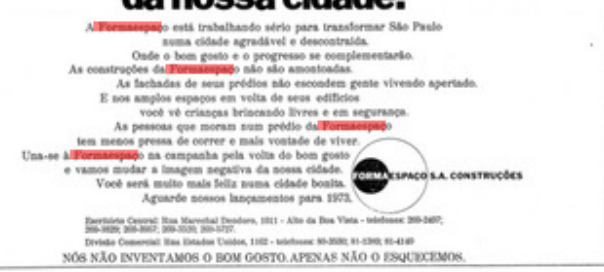

Figura 3: Anúncio publicitário da construtora Formaespaço Fonte: Jornal Folha de São Paulo - Janeiro 1973

\section{Nós náo inventamos \\ obomgosto. \\ Apenas não o esquecemos}

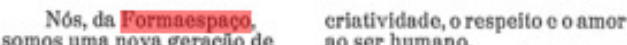

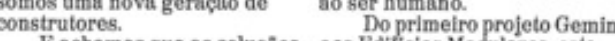
de moradia que o progresso acelerado está Impondo a nossa constante. cidade, estato sacrificando
totalmente obom gosto. Que na nossa opiniấ, indispensável a vidáa quan

o ar que respiramos.
Nos acreditamos que as pessons apoiariam alguém que do multo que esse progress

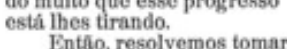
essa iniciativa. A nosso modoc construindo. para consumo, preferimos de viver.
Para isso, eonhecemos
primeiro o que se fazia de mai
attualizado, no exterior. Ao conhecimento tóenic
adquirido, juntamos entín a Mas a nossa maior satisfaçâo, como construtores, encontraram a liberdade e projetos. Por isso, nós estamos muito
otimistas em relaçéo ao futuro descobrindo que eom bom gosto essa imagem negativa Este anćncio é um promessa de que a Formaespaç

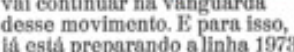
Aguarde.

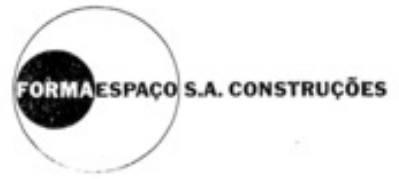

A1.Jauaperi, 176-SP-TeL-71-2196 - 70-5949 - 701-0107 (direto)

Figura 4: Anúncio publicitário da construtora Formaespaço Fonte: Jornal Folha de São Paulo - Março 1973 
Muito do comprometimento com a qualidade da arquitetura impressa nos edifícios da Formaespaço foi determinado por um de seus fundadores, o americano Eugene Gordon. Gordon associou-se a um jovem engenheiro da Escola Politécnica, João da Rocha Lima, que se empenhou no crescimento da empresa. Ao final do período favorável à construção da habitação - segunda metade da década de 70 - com o aumento do custo dos terrenos em função da lei de zoneamento e mudança no quadro para obter financiamentos, a empresa entrou em colapso financeiro.

A qualidade dos projetos desenvolvidos manteve-se alinhada enquanto estes foram desenvolvidos nos escritórios dos arquitetos autores dos projetos. Para agilizar ainda mais a etapa de projeto, foi criada a Merisa, empresa ligada à Formaespaço, que passou a desenvolver os projetos e conduzir especificações a partir de anteprojetos contratados. Esta foi uma experiência avaliada negativamente pelos arquitetos, inclusive dentro da própria Merisa, pois a divergência de interesses resultou em descaracterização e consequente perda da essência das propostas originais ${ }^{6}$.

A simultaneidade da produção da Formaespaço com o período descrito foi confirmada com as seguintes obras: Conjunto de casas do Jardim Prudência, primeiro projeto do arquiteto Abrahão Sanovicz para a construtora de 1968 [Figura 5]. Os edifícios Gemini [Figura 6], do arquiteto Eduardo de Almeida, são de 1969, mesmo ano do Conjunto Residencial Nova Cidade [Figura 7], outro projeto de Sanovicz. Em 1970, construiu o Modular Alfa [Figura 8], o primeiro de uma série de edifícios repetidos.

${ }^{6}$ Dados extraídos das entrevistas com o arquiteto João Honório de Mello Filho e Eugene Gordon, fundador da Formaespaço para a dissertação de mestrado IMBRONITO, Maria Isabel - "Três Edifícios de Habitação para a Formaespaço: Modulares, Gemini e Protótipo". FAU-USP. São Paulo, 2003. 
De 1970 a 1973, a Formaespaço construiu sobre o conceito de edifícios em série. O edifício Protótipo, do arquiteto Paulo Mendes da Rocha, desenvolvido até a fase de projeto executivo, data de 1972 . No ano seguinte foi construído o prédio da Rua Jauaperi - Edifício Clermont [Figura 9], do mesmo arquiteto. As adaptações do Gemini para produção em série resultaram nos edifícios Lark e Coronet [Figura 10], executados em 1973. O edifício Modular, a partir de 1973, foi também adaptado para uma segunda fase, e sofreu profundas alterações no sistema construtivo, numa decisão que partiu provavelmente da construtora.

A experiência da Formaespaço transformou-se em um conjunto de edifícios de conformação variada e programas diferentes, mas de construção semelhante. Ao comparar os projetos, conclui-se que apresentam o mesmo princípio construtivo, utilizam os mesmos materiais e resultam na mesma expressão.
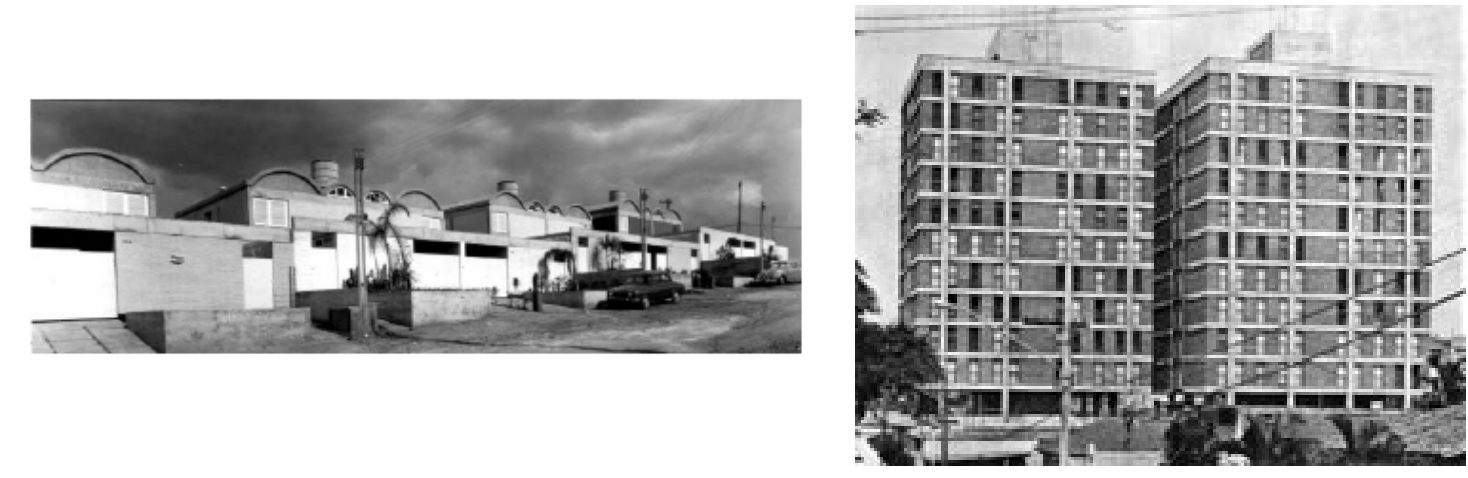

Figura 5 - Conjunto de Casas Jardim Prudência, São Paulo - 1968. Abrahão Sanovicz.

Figura 6 - Edifícios Gemini I e II - Eduardo de Almeida Fonte: Acervo escritório Elito Arquitetos apresentada em Silva, H.A.A. Abrahão Sanovicz: O Projeto como Pesquisa - Tese de doutorado. FAU USP - São Paulo, 2004

coordenação Profạ Drạ Ruth Verde Zein FAUMackenzie 


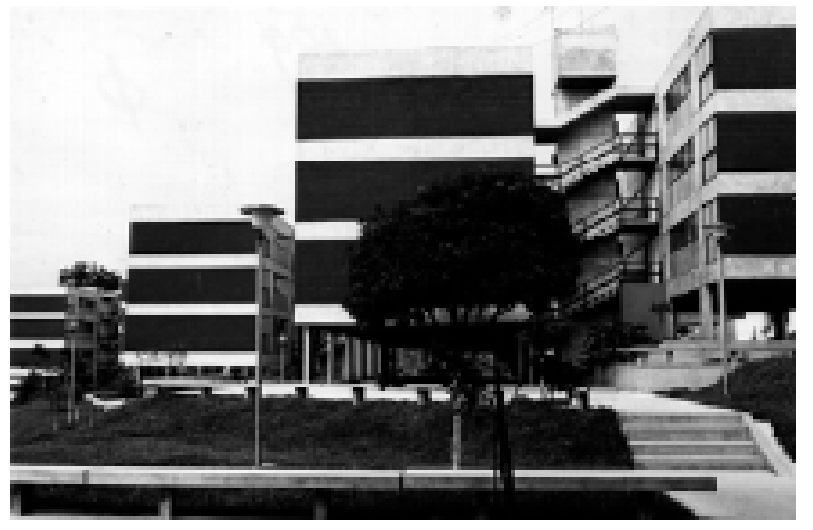

Figura 7 - Cj. Residencial Nova Cidade, Jundiaí - 1969. Abrahão Sanovicz

Fonte: Acervo escritório Elito Arquitetos apresentada em Silva, H.A.A. Abrahão Sanovicz: O Projeto como Pesquisa - Tese de doutorado. FAU USP - São Paulo, 2004

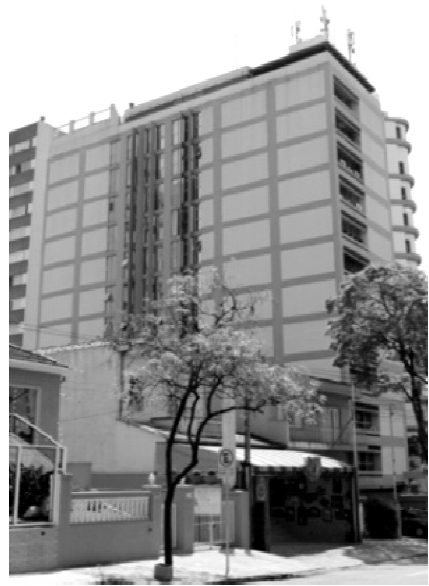

Figura 9 - Edifício Clermont - Paulo Mendes da Rocha Foto - Priscylla Lima

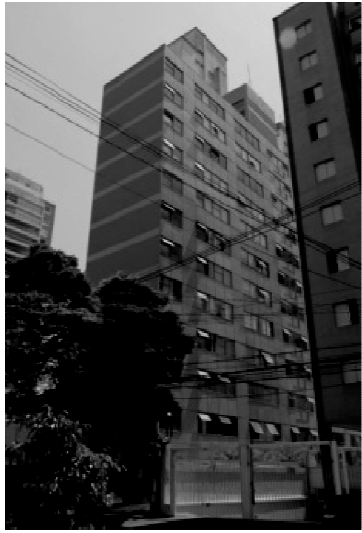

Figura 8 - Modular Alfa - Abrahão Sanovicz Foto: Priscylla Lima

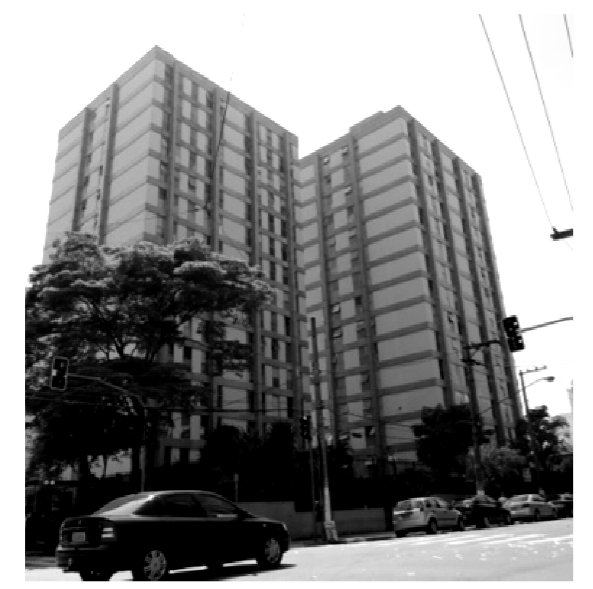

Figura 10 - Edifícios Coronet I e II - Eduardo de Almeida Foto - Priscylla Lima 


\subsection{FORMAESPAÇO}

E 0 ARQUITETO

ABRAHÃO SANOVICZ
A produção de habitação de Abrahão Sanovicz está diretamente ligada aos edifícios da Formaespaço. Foi ele o arquiteto que mais projetou para a construtora, enquanto a reprodução do Modular fez do edifício, um destaque no conjunto de sua obra.

A solicitação de projetar edifícios em série partiu da construtora. A proposta inicial contemplava prédios baixos com apartamentos de baixo custo localizados na periferia e edifícios de maior gabarito com apartamentos de três quartos para a classe média em bairros em expansão imobiliária na cidade.

A encomenda representou, para o arquiteto, a oportunidade de aplicar princípios do desenho industrial em projeto de edifícios.

O interesse pelo desenho industrial surgiu ainda como estudante na FAU-USP, onde se formou em 1958. Após trabalhar com design em Milão na Itália, no Studio de Marcello Nizzoli, retornou ao Brasil no início dos anos 60 e tornou-se professor de desenho industrial na própria FAU, no momento de discussão da formação do arquiteto decorrida da reforma do ensino de 1962, conduzida por Vilanova Artigas.

Sanovicz acreditava que o design, no Brasil, deveria ser levado ao edifício, levando em conta a questão habitacional que considera, além de vantagens da produção em grande escala, uma maneira de levar qualidade de desenho a um número maior de pessoas. Sobre o Modular, declarou: 
Com esse projeto, eu tinha um protótipo, e estava finalmente conseguindo mostrar que era possível levar todo aquele conhecimento da arquitetura [que, até então eram aplicados em projetos diferenciados que, no caso, eram clientes do nosso âmbito de amizades] expandindo essa nova linguagem para pessoas desconhecidas - porque nós não sabíamos quem era o cliente ${ }^{7}$.

A transposição do desenho industrial enquanto método de projeto ao edifício se consistiu na aplicação de elementos padronizados sobre estruturas moldadas in loco e racionalizadas em sua execução. Segundo IMBRONITO, componentes e estrutura eram compatibilizados em suas medidas utilizando princípios da coordenação modular. Na concepção do projeto, estavam contidos os procedimentos de obra e as etapas de construção.

Abrahão Sanovicz estabeleceu para a Formaespaço algumas premissas à produção dos edifícios:

- Planta livre de pilares internos, possibilitando diferentes arranjos;

- Estrutura na periferia do edifício, com vãos que não solicitassem recursos sofisticados como a laje nervurada ou o caixão perdido;

- Circulação vertical no meio do edifício, criando assim, duas habitações por andar, simétricas;

7 Sanovicz faz uma leitura da emancipação através do desenho para Artigas, segundo o qual o desenho só adquire este papel quando vinculado ao conhecimento do "saber fazer", e aplicado de maneira ampla, através da participação do arquiteto nas diversas escalas. Ver Catherine Gati em PMSP, CCSP, op. cit., entrevista em 28/10/1987, p1. 
- Eliminação de corredores internos, resultando em um desenho que, a partir do eixo longitudinal do apartamento, distribui-se alinhados de um lado os quartos e serviço e do outro, a sala livre mais os banheiros, implantados praticamente como um volume independente;

- Os pilares, vigas e lajes deveriam ser concretados de uma única vez formando a estrutura fundamental do prédio;

- Vãos deixados entre as vigas-peitoril permitiriam a chegada dos caixilhos à obra praticamente prontos;

- As divisórias internas seriam executadas com painéis de gesso pré-moldados, com sete $\mathrm{cm}$ de espessura, $50 \mathrm{~cm}$ de largura e o comprimento igual ao pé direito;

- As instalações hidráulicas seriam reduzidas a poucas prumadas;

- Modulação estrutural, permitindo o reaproveitamento das formas e padronização das dimensões das diversas partes da estrutura, de maneira a possibilitar que toda a

- Ferragem, racionalizada, fosse produzida fora do canteiro.

$\mathrm{O}$ arquiteto afirma:

A construção começa então a se tornar montagem de suas partes, num compromisso entre o sistema tradicional construtivo e as possibilidades industriais do mercado. Os elementos de "acabamento" da obra são os normais do mercado. Os elementos essenciais do projeto, racionalizados, possibilitam aos setores de planejamento de 
obra determinarem com precisão maior, os custos e os tempos de execução da mesma ${ }^{8}$.

A preocupação de Sanovicz em conciliar o desenho industrial ao projeto de arquitetura é anterior à experiência da Formaespaço. Surgiu em 1963, no edifício da Rua Pará, no bairro paulistano de Higienópolis. Esta relação entre edifícios ocorre na idealização do projeto e na proposta construtiva. $O$ edifício da Rua Pará [Figuras 11 a 14] possui planta retangular com estrutura regularizada em concreto aparente e concentra um núcleo de instalações - banhos, circulações verticais e estrutura central. A face sul contempla os serviços, enquanto quartos e salas se voltam para o norte, sendo que as salas ocupam também as extremidades do edifício. Estas fachadas, tirando os serviços, recebem externamente um brise produzido industrialmente. Outro edifício, contemporâneo aos Modulares, mas feito fora da Formaespaço, é o edifício da Rua Fiandeiras, de 1972 [Figuras 15 e 16]. Este último adota, para solucionar as aberturas, um elemento pré-moldado de concreto na fachada, que recebe caixilhos e blocos vazados de concreto.

${ }^{8}$ Declaração de Abrahão Sanovicz extraída do volume "Sistematização Crítica da Obra de Arquitetura" para Obtenção do Título de Livre Docente. SANOVICZ, Abrahão. FAU-USP. São Paulo, 1997. P.51. 


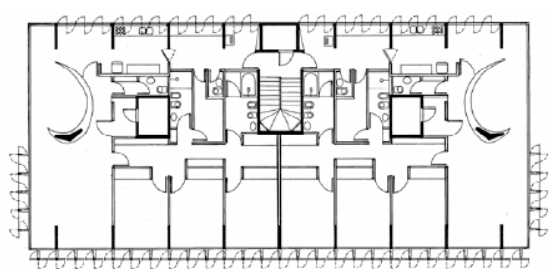

Figura 11- Ed. Rua Pará - Planta Pavimento Tipo Fonte: Silva, H.A.A. Abrahão Sanovicz: O Projeto como Pesquisa Tese de doutorado. FAU USP - São Paulo, 2004

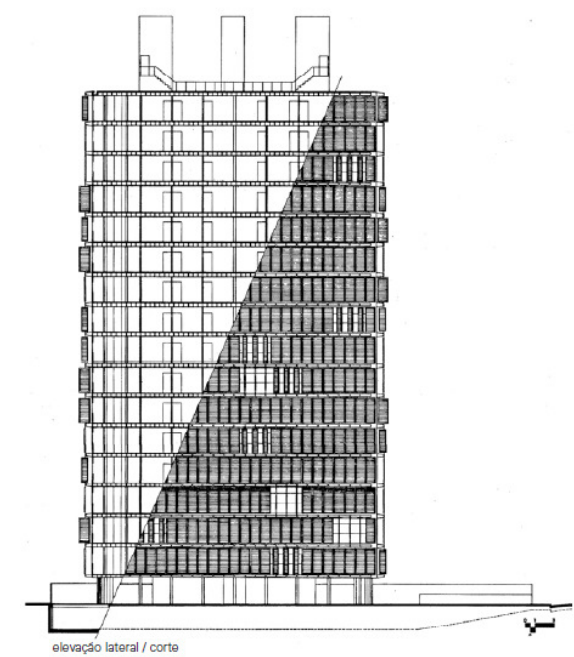

Figura 13 - Ed. Rua Pará - Elevação Lateral / Corte Fonte: Silva, H.A.A. Abrahão Sanovicz: O Projeto como Pesquisa - Tese de doutorado. FAU USP - São Paulo, 2004

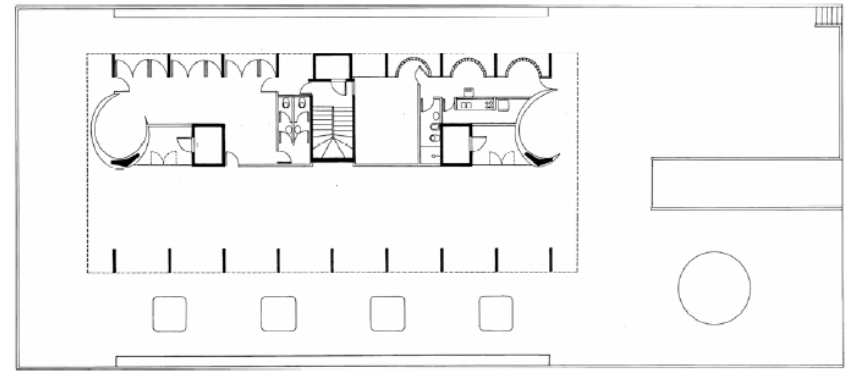

Figura 12 - Ed. Rua Pará - Implantação

Fonte: Silva, H.A.A. Abrahão Sanovicz: O Projeto como Pesquisa - Tese de doutorado. FAU USP - São Paulo, 2004

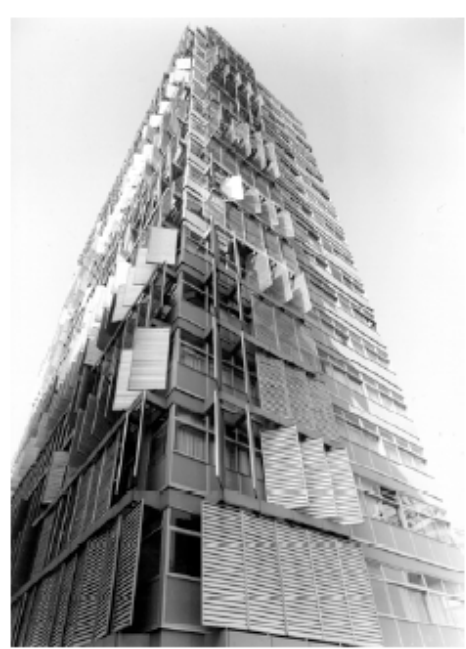

Figura 14 - Ed. Rua Pará, São Paulo - 1963.

Fonte: Silva, H.A.A. Abrahão Sanovicz: O Projeto como Pesquisa - Tese de doutorado. FAU USP - São Paulo, 2004 


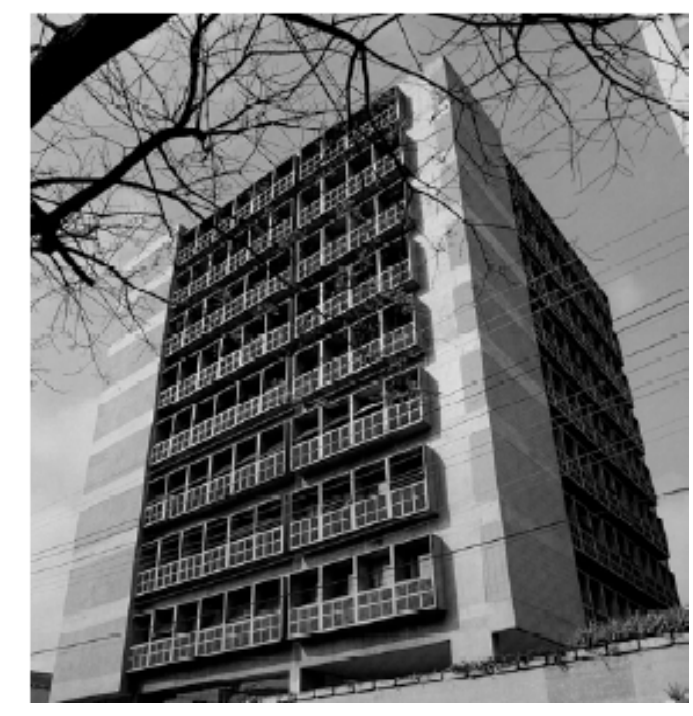

Figura 15 - Edifício Fiandeiras, São Paulo - 1972.

Fonte: Acervo escritório Elito Arquitetos apresentada em Silva, H.A.A. Abrahão Sanovicz: O Projeto como Pesquisa Tese de doutorado. FAU USP - São Paulo, 2004

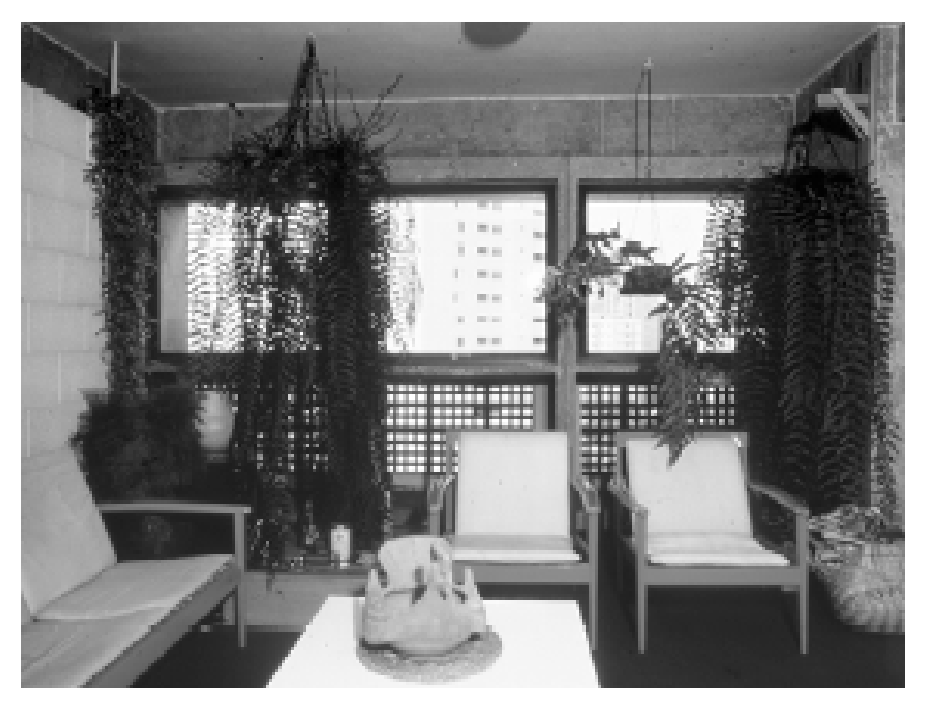

Figura 16 - Edifício Fiandeiras, São Paulo - 1972.

Fonte: Acervo escritório Elito Arquitetos apresentada em Silva, H.A.A. Abrahão Sanovicz: O Projeto como Pesquisa - Tese de doutorado. FAU USP - São Paulo, 2004 
Os edifícios projetados pelo arquiteto para a Formaespaço são de três tipos, nomeados por Sanovicz de Edifícios Modulares:

\section{EDIFÍCIOS MODULARES DE TRÊS PAVIMENTOS}

\section{CONJUNTO NOVA CIDADE E QUATRO MARIAS}

São conjuntos econômicos implantados em grandes lotes afastados da capital paulista, sendo o primeiro em Jundiaí e o segundo em São Bernardo do Campo. De modo geral, são compostos por edifícios de três pavimentos, mais térreo livre. Os edifícios são formados por blocos retangulares contendo dois apartamentos por andar. Dois blocos dispostos paralelamente são unidos pela circulação vertical. Este mesmo arranjo é utilizado na composição de conjuntos maiores. $\mathrm{O}$ apartamento com área útil de $74 \mathrm{~m}^{2}$ contém três quartos, sala, um banheiro, cozinha e área de serviço.

\section{EDIFÍCIO MODULARES DE DOIS QUARTOS}

\section{GRANJA JULIETA E OLYMPIA}

São dois edifícios, um de 16 e outro de 10 pavimentos, também compostos por dois blocos unidos pela circulação vertical. Em cada um dos blocos, são dispostos dois apartamentos de $82 \mathrm{~m}^{2}$, com dois quartos, sala, cozinha, banheiro, área de serviço, quarto e banheiro de empregada. 


\section{EDIFÍCIOS MODULARES DE TRÊS QUARTOS}

MODULAR ALFA, BETA, GAMA, DELTA I E II, EPSILON E DZETA

Os Edifícios Modulares de 11 pavimentos são dimensionados para se adaptar em lotes urbanos de 20x50m. Os edifícios em lâmina contêm dois apartamentos por andar de $125 \mathrm{~m}^{2}$, divididos em três quartos, tendo um deles banheiro privativo, mais um banheiro que serve os outros dois quartos, cozinha, lavanderia, quarto e banheiro de empregada. Circulação vertical contida no centro do edifício. Todos esses prédios foram implantados próximos uns aos outros, na região do bairro de Moema. Posteriormente, o projeto-padrão foi modificado e implantado em outros bairros.

O primeiro projeto de Abrahão Sanovicz para a Formaespaço foi um conjunto de 22 casas com cobertura em abóbodas no Jardim Prudência, em 1968. Este pequeno conjunto já considerou questões de um projeto em série, porém tratando-se de um programa de residência unifamiliar, não será estudado neste trabalho assim como o primeiro subgrupo dos Edifícios Modulares de Três Pavimentos composto pelo Conjunto Nova Cidade [Jundiaí, 1969] e Quatro Marias [São Bernardo do Campo, 1972] que apresentam como principais premissas a construção de menor valor econômico, baixo gabarito e no caso do Conjunto Nova Cidade um programa misto, distanciando-se do foco principal deste estudo.

Do grupo de Edifícios Modulares, foram selecionados para análise um exemplar dos Edifícios Modulares de Dois Quartos - Edifício Granja Julieta e dois exemplares dos Edifícios Modulares de Três Quartos Modular Alfa e Modular Delta I e II. 
O edifício Modular Alfa de 1970, localiza-se na Rua Graúna, 271, Moema. Foi o pioneiro de uma seqüência de edifícios de onze pavimentos realizado pela Formaespaço [Figuras 17 e 18].

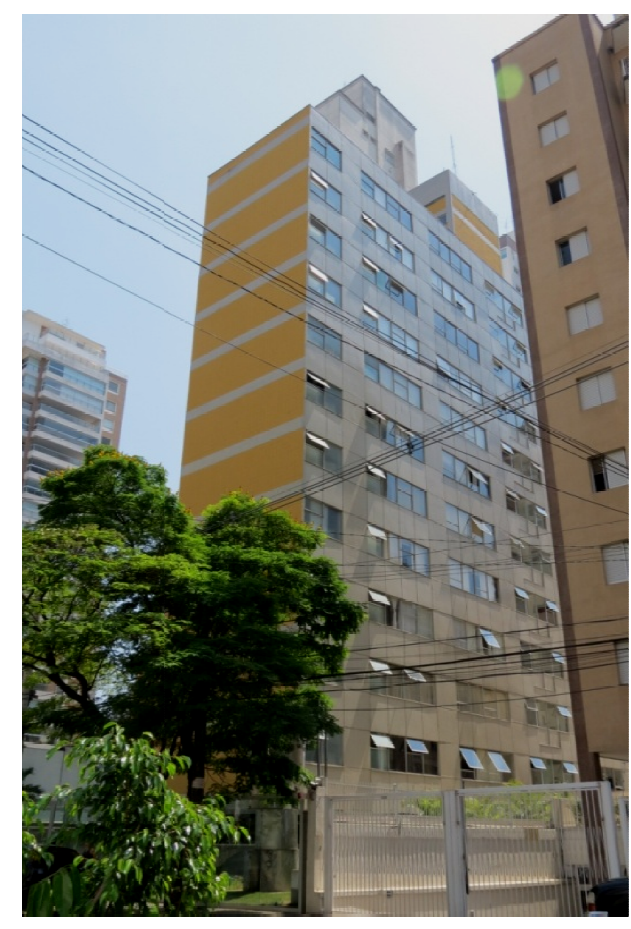

Figura 17 - Edifício Modular Alfa, São Paulo - 1970. Foto - Priscylla Lima

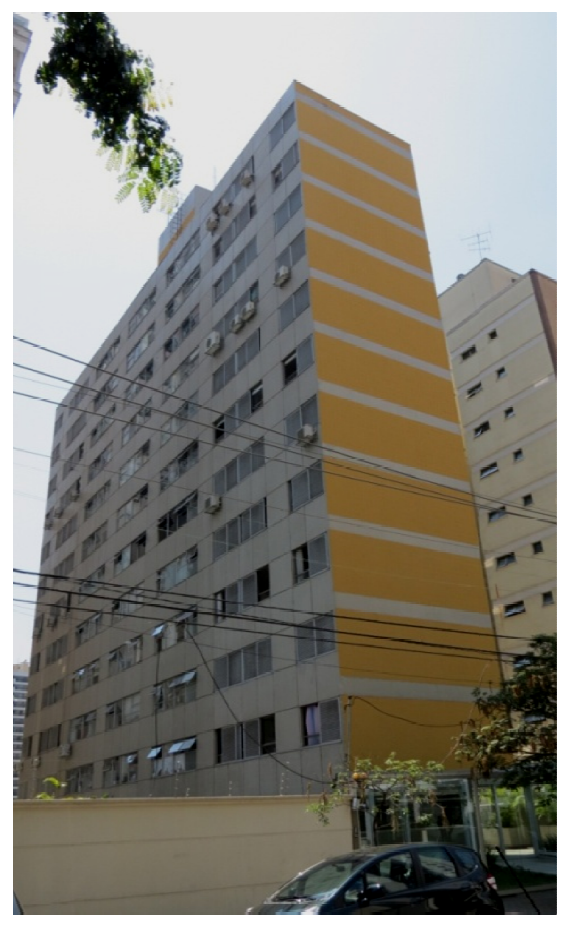

Figura 18 - Edifício Modular Alfa, São Paulo - 1970. Foto - Priscylla Lima 
Edifício em lâmina sobre pilotis, os Modulares possuem uma volumetria que decorre da ocupação do lote de $20 \times 50 \mathrm{~m}$. Os prédios foram construídos com menor gabarito e ocupação do terreno, tornando possível adotar índices urbanísticos menores que os permitidos por lei ${ }^{9}$. Por opção da construtora, os lotes foram comprados em regiões, na época, mais afastadas do centro da cidade. Sendo assim, conseguiram reverter em benefícios para o prédio o custo menor do terreno.

O térreo configura uma praça que faz o acesso e comporta equipamentos para as crianças, esculturas e jardins. ${ }^{10} \mathrm{O}$ mesmo, não permanece livre. O piloti ocupado abriga funções comuns e o acesso à circulação vertical. Esta ocupação é recuada apenas o suficiente para garantir a identificação do espaço do piloti e também para desenhar uma circulação externa coberta, que conduz aos elevadores [Figuras 19 e 20].

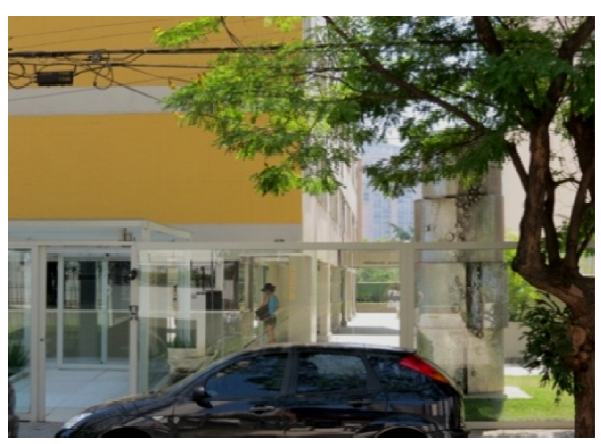

Figura 19 - Edifício Modular Alfa, São Paulo - 1970. Foto - Priscylla Lima

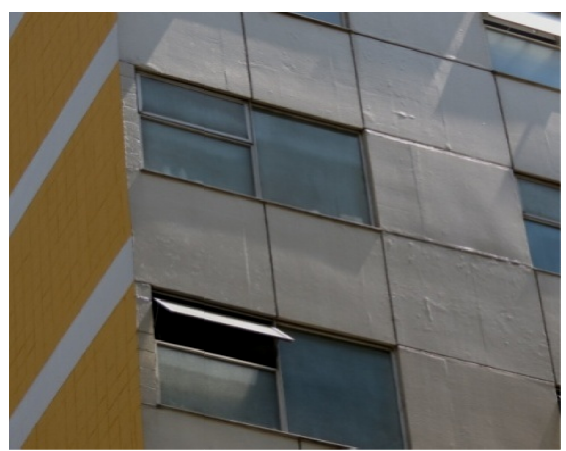

Figura 20 - Edifício Modular Alfa, São Paulo - 1970 Foto - Priscylla Lima

${ }^{9} \mathrm{O}$ coeficiente de aproveitamento em vigor era seis. A área construída corresponde a pouco mais da metade do permitido segundo cálculo equivalente para Modular Beta. Dados extraídos da dissertação de mestrado VILARIÑO, Maria do Carmo - "Habitação Verticalizada na Cidade de São Paulo dos anos 30 aos anos 80. Investigação acerca da contribuição dos arquitetos modernos ao tema. Estudos de Caso". FAU-USP. São Paulo, 2000. P.260.

${ }^{10}$ Alguns edifícios exibem junto à rua, escultura de Caciporé Torres. 


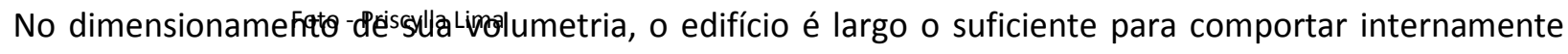
dois ambientes, e estreito o suficiente para resolver o vão transversal de 7,50m em dois apoios, evitando o pilar central e deixando livre a planta do andar. ${ }^{11}$ Esta planta livre, confere ao apartamento uma excelente flexibilidade, exceto pelas instalações, uma vez que as divisórias entre os ambientes são leves e os caixilhos homogêneos.

A circulação vertical central permite acesso a dois apartamentos, com entradas separadas para a sala e a cozinha. O apartamento cumpre o programa estabelecido pela Formaespaço setorizado longitudinalmente: de um lado agrupam-se os serviços, cozinha e quartos que são articulados pela sala. Nenhum ambiente transpõe o edifício no sentido transversal: quartos cozinha e serviço abrem-se para uma fachada enquanto sala e banheiros abrem-se para a outra. Para garantir boa orientação solar dos quartos, o edifício poderia ser implantado rebatido. A disposição da planta permite ainda iluminar o hall de acesso aos apartamentos.

Característica do Modulares, as empenas estruturais longitudinais são uma trama de pilares e vigaspeitoris e contêm todas as aberturas do edifício sendo, portanto, repletas de vãos. Desta forma, a elevação longitudinal é definida pela própria estrutura.

\footnotetext{
${ }^{11}$ Abrahão Sanovicz, em depoimento para a pesquisadora Catherine Gati, fala sobre a importância de compreender os postulados da arquitetura moderna, e não apenas adotá los como dogma Lembra com propriedade de Lúcio Costa, no projeto do Ministério Educacão no Rio de Janeiro, utiliza o piloti e a planta livre No primiro caso, o edifício Ver entrevista à pesquisadora Catherine Gati, PMSP, CCSP, idem, entrevista em 12/03/1988, PP. 2-5.
} 
Os balanços que avançam nas extremidades sustentam as paredes cegas de bloco de concreto que definem o edifício em sua menor dimensão.

Na compreensão do processo de projeto dos Edifícios Modulares, nota-se novamente construção e arquitetura numa relação indissociável, com redução dos elementos e procedimentos construtivos ao essencial. Construtivamente, os edifícios foram pensados em termos de estrutura, leves vedações internas e vãos preenchidos com caixilhos.

O objetivo da construtora era produzir um Modular em 280 dias. A estrutura de concreto moldada in loco e deixada aparente adotava fôrmas reutilizáveis para fazer as empenas ${ }^{12}$, as vigas transversais vencendo $7,50 \mathrm{~m}$ e as lajes vencendo $3,00 \mathrm{~m}$. A exceção era o núcleo central e escada ${ }^{13}$. As únicas vedações, de frente e fundo do edifício, eram executadas por dentro e permaneceriam aparentes externamente. Após esta etapa, os componentes eram acrescentados. Os caixilhos modulados de alumínio eram fixados por dentro e suprimiam acabamentos. Para evitar desperdício na obra e diminuir o trânsito de argamassa e bloco de vedação, optou-se por paredes internas em painéis de gesso de sete $\mathrm{cm}$ de espessura. Os painéis leves permitiram economia no dimensionamento da estrutura e fundações, além de apresentar maior rendimento na colocação e acabamento pronto para receber pintura. Armários modulados faziam a divisão entre os quartos.

\footnotetext{
${ }^{12}$ Dados extraídos das entrevistas com o engenheiro Sergio Facchini para a dissertação de mestrado IMBRONITO, Maria Isabel - "Três Edifícios de Habitação para a Formaespaço: Modulares, Gemini e Protótipo". FAU-USP. São Paulo, 2003.

${ }^{13}$ Dados extraídos da dissertação de mestrado IMBRONITO, Maria Isabel - "Três Edifícios de Habitação para a Formaespaço: Modulares, Gemini e Protótipo". FAU-USP. São Paulo, 2003.
} 
A instalação hidráulica dos banheiros foi resolvida com a adoção de um rebaixo localizado junto aos aparelhos, a gaveta hidráulica. Conforme as palavras do próprio Abrahão Sanovicz:

\section{A construção começa a se tornar uma montagem de suas partes, num compromisso} entre o sistema tradicional construtivo e as possibilidades industriais do mercado ${ }^{14}$.

O edifício Modular Alfa, por ser o primeiro dos Modulares de 11 pavimentos, tornou-se um modelo em escala real do edifício produzido em série ${ }^{15}$. O fato de serem edifícios repetidos permitiu que fossem feitos ajustes de modo a corrigir problemas e propor alterações construtivas. Assim, o sistema resolvido e bem configurado de prédios abriga um processo de evolução do projeto. Com um olhar mais atento, IMBRONITO aponta diferenças que demonstram um caminho de decisões técnicas e financeiras. A viga peitoril em concreto, por exemplo, aparece apenas nos Modulares Alfa, Beta e Gama. Foi substituída nos Modulares Delta, Epsilon e Dzeta por uma viga de menor altura e painéis de concreto completando o vão até o caixilho, provavelmente para reduzir custos. Existe variação também no desenho dos caixilhos e em certos detalhes construtivos, como a adoção de pingadeiras para evitar percolação de água nos balanços das fachadas transversais.

\footnotetext{
${ }^{14}$ Sanovicz, ibidem, p.51.

${ }^{15}$ Depoimento de Sanovicz para Marcos Cartum, PMSP, CCSP, op. cit., entrevista em 11/10/1984, p.6.
} 
PROJETO EDIIFÍCIO

MODULAR ALFA

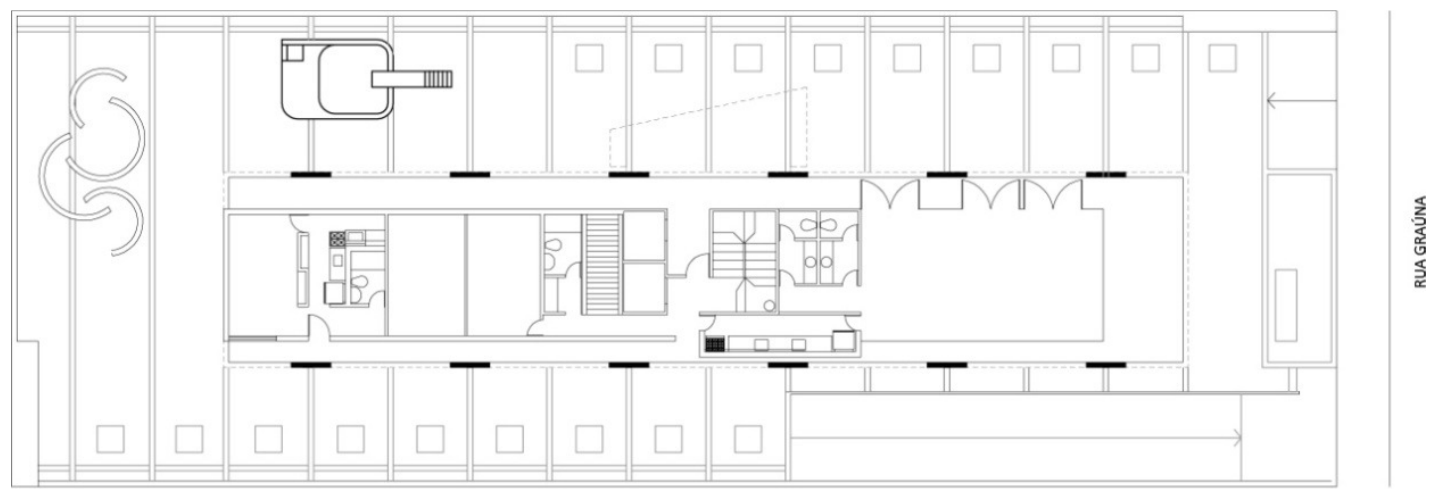

(2) $0^{12}$

Planta Pavimento Terreo

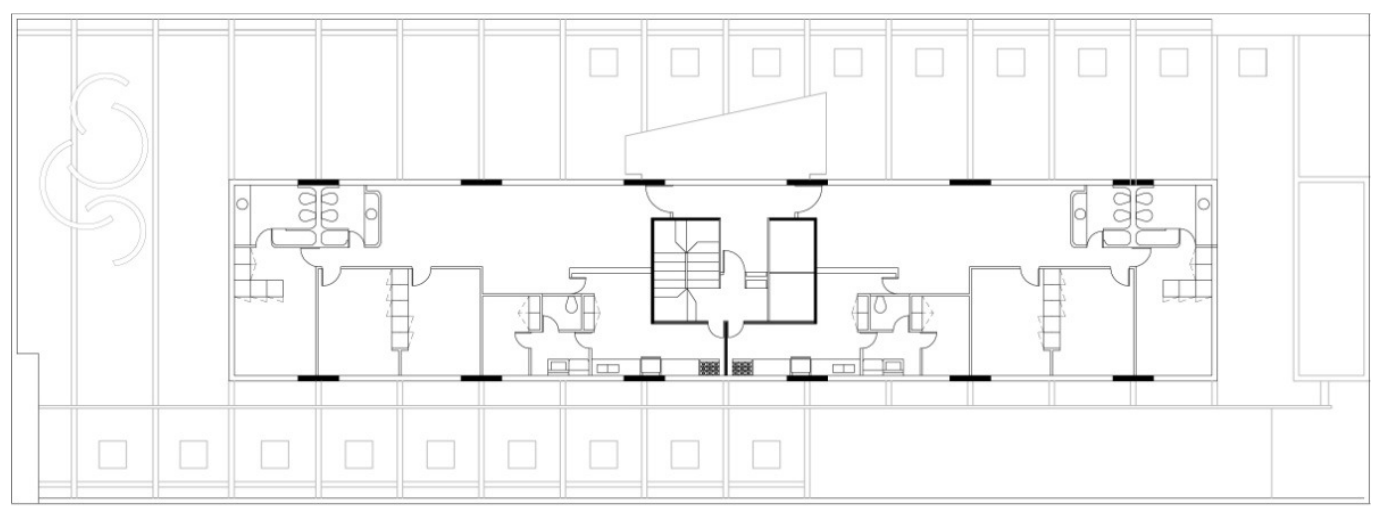

(1) $0^{12}$

Planta Pavimento Tipo 


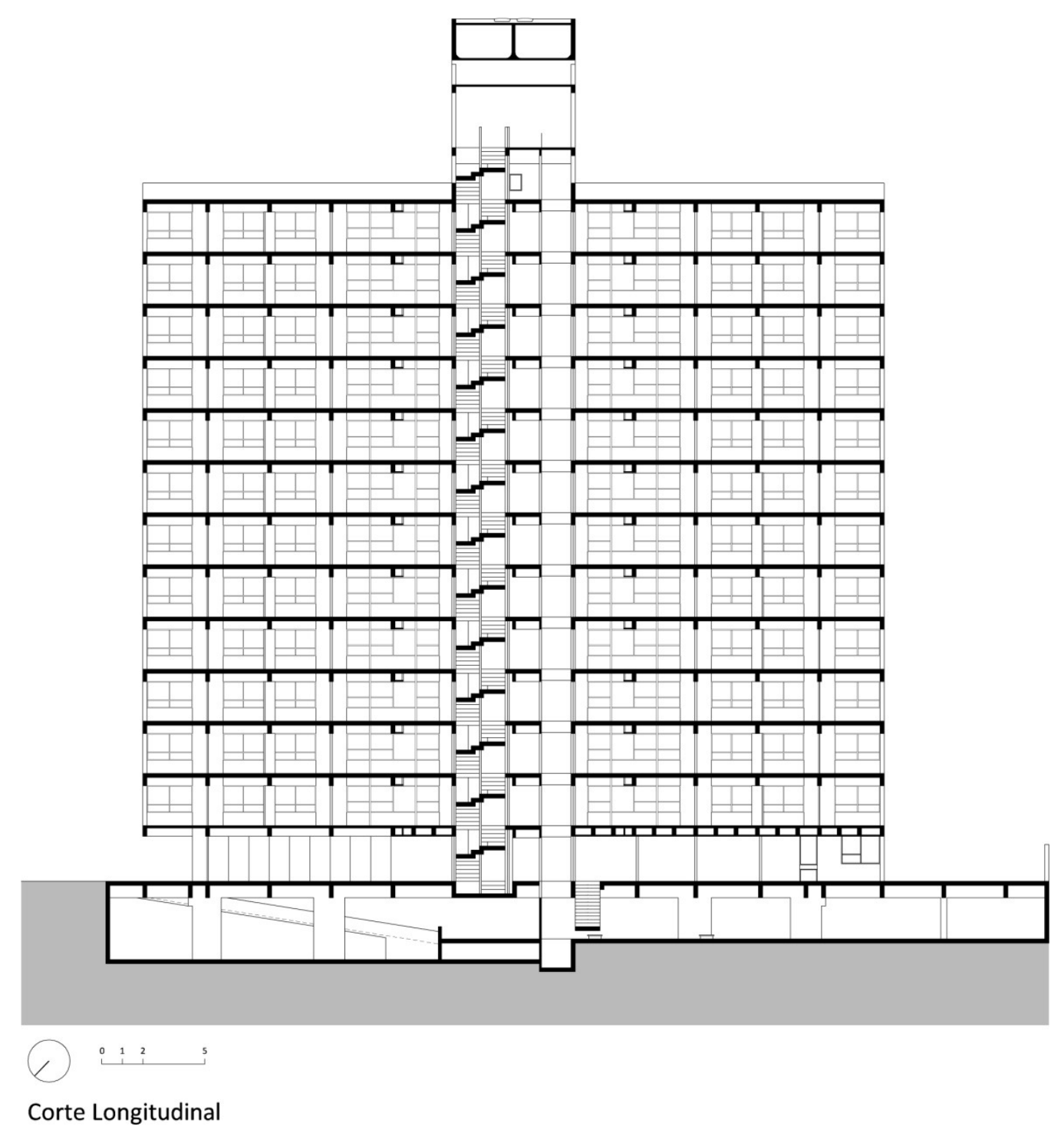



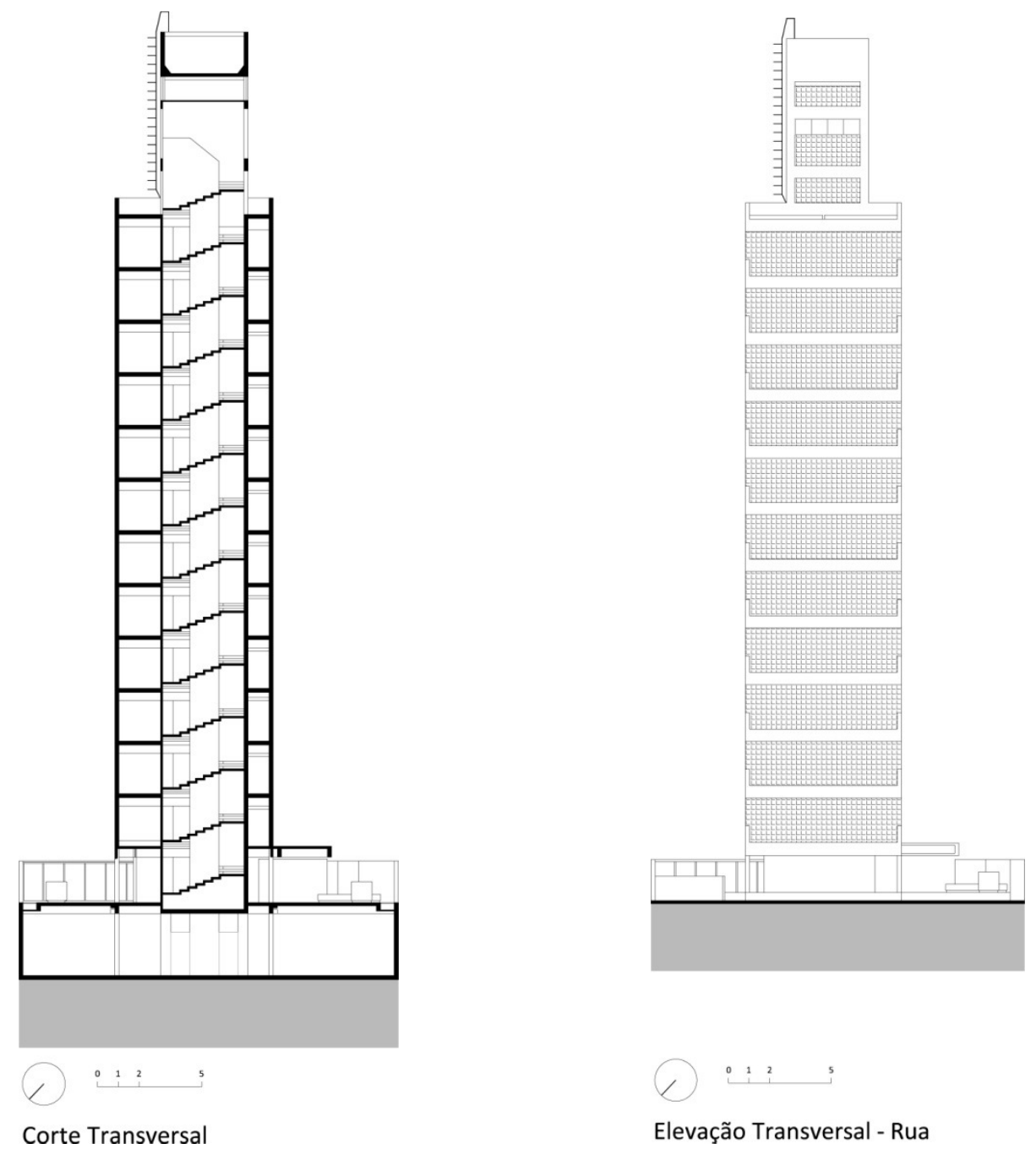


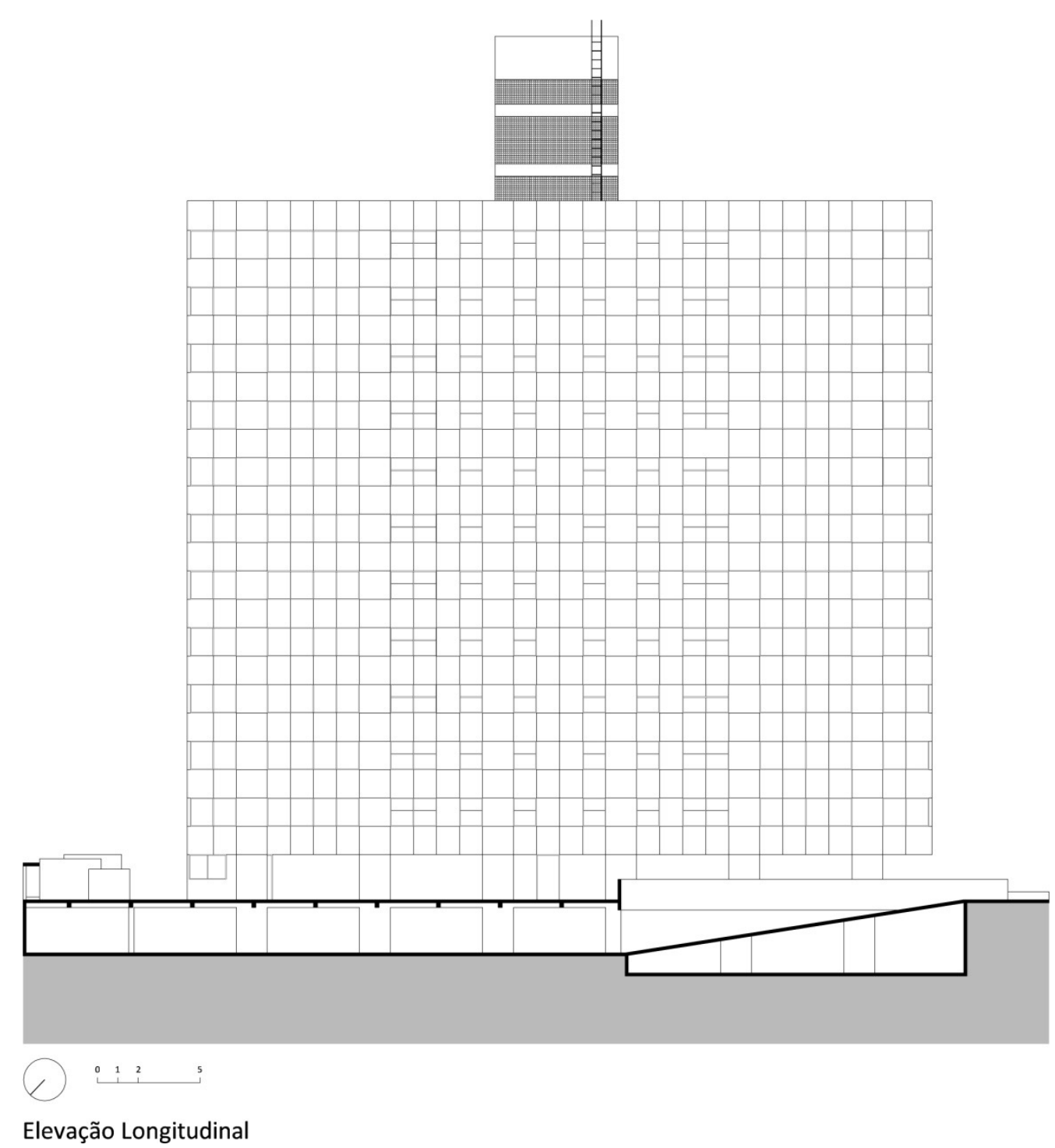


Os seis Modulares construídos em seqüência localizam-se todos nas imediações do primeiro. Destes, destacam-se os edifícios Delta I e II por sua implantação [Figuras 21, 22, 23 e 24]. Por se tratar de um terreno maior, as duas lâminas implantadas paralelas foram unidas por uma marquise no térreo. Localizados à Av. Lavandisca, 52, Moema

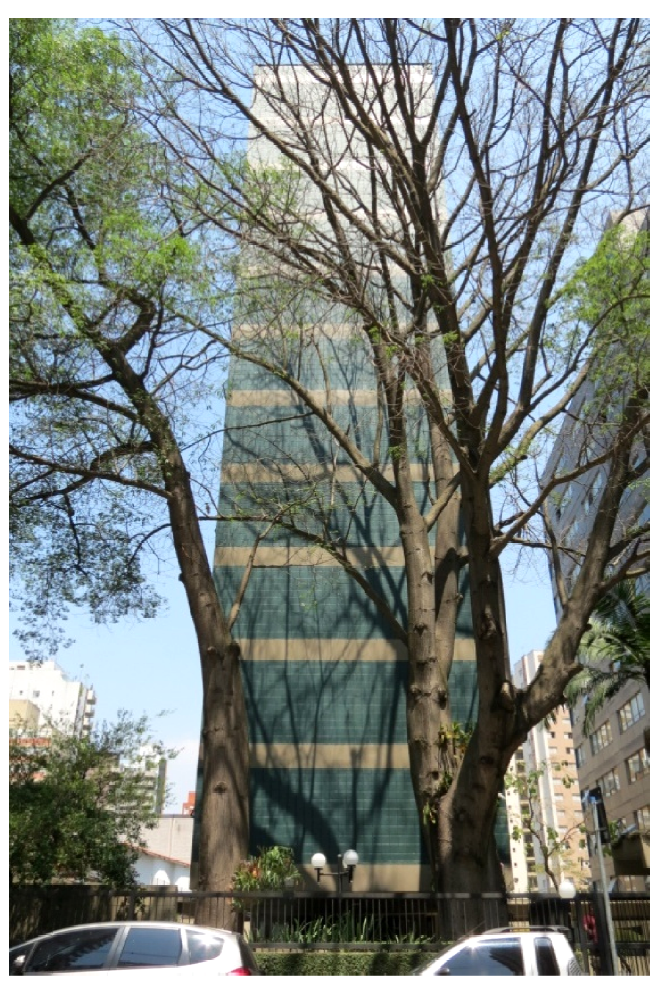

Figura 21 - Modular Delta I e II, São Paulo - 1971. Foto - Priscylla Lima

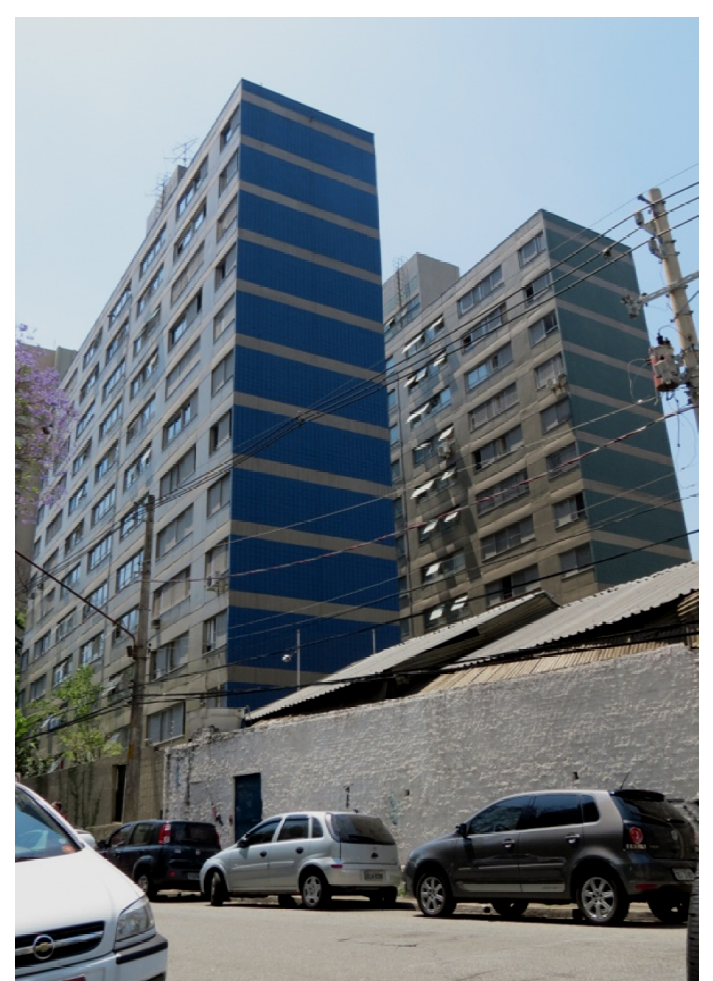

Figura 22 - Modular Delta I e II, São Paulo - 1971 Foto - Juliano Barros 


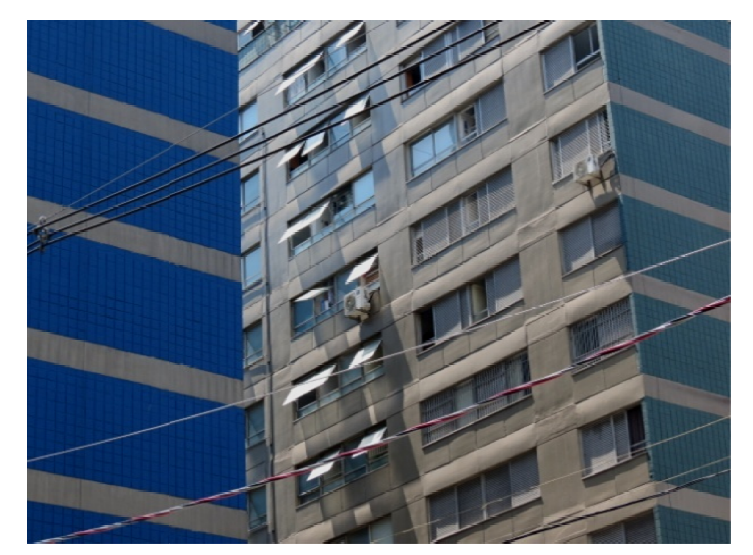

Figura 23 - Modular Delta I e II, São Paulo - 1971. Foto - Priscylla Lima

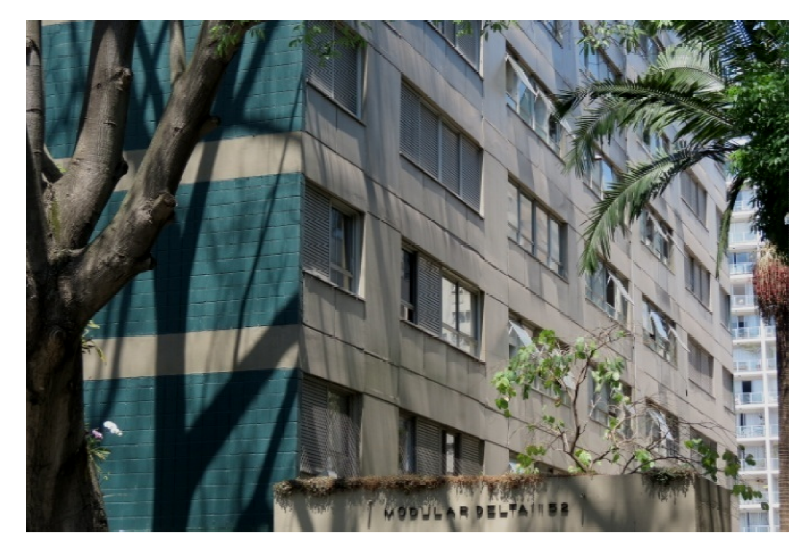

Figura 24 - Modular Delta I e II, São Paulo - 1971. Foto - Juliano Barros 
PROJETO EDIFÍCIO

MODULAR DELTA I E II

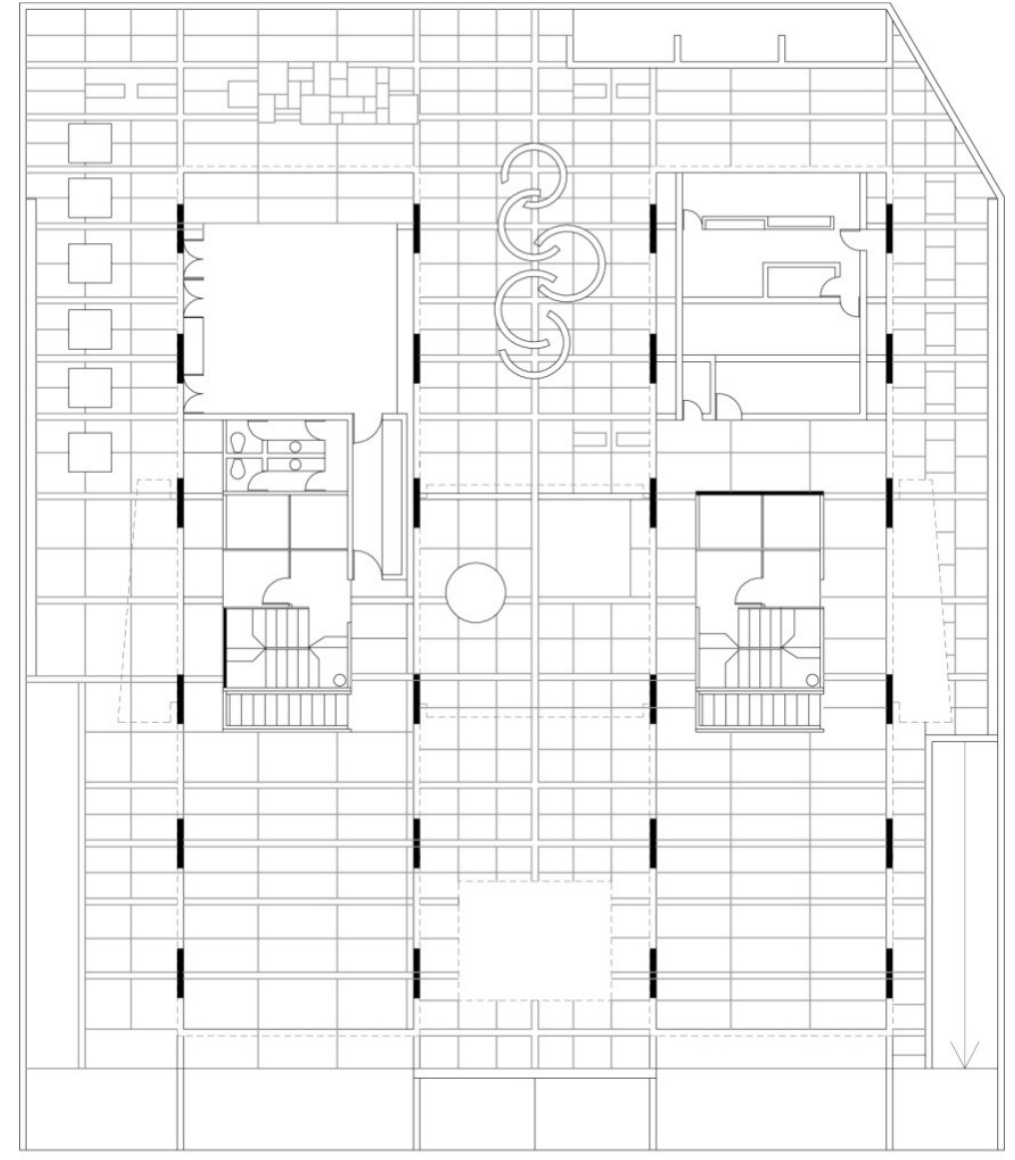

RUA LAVANDISCA

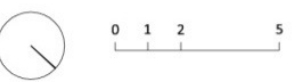

Planta Pavimento Terreo 


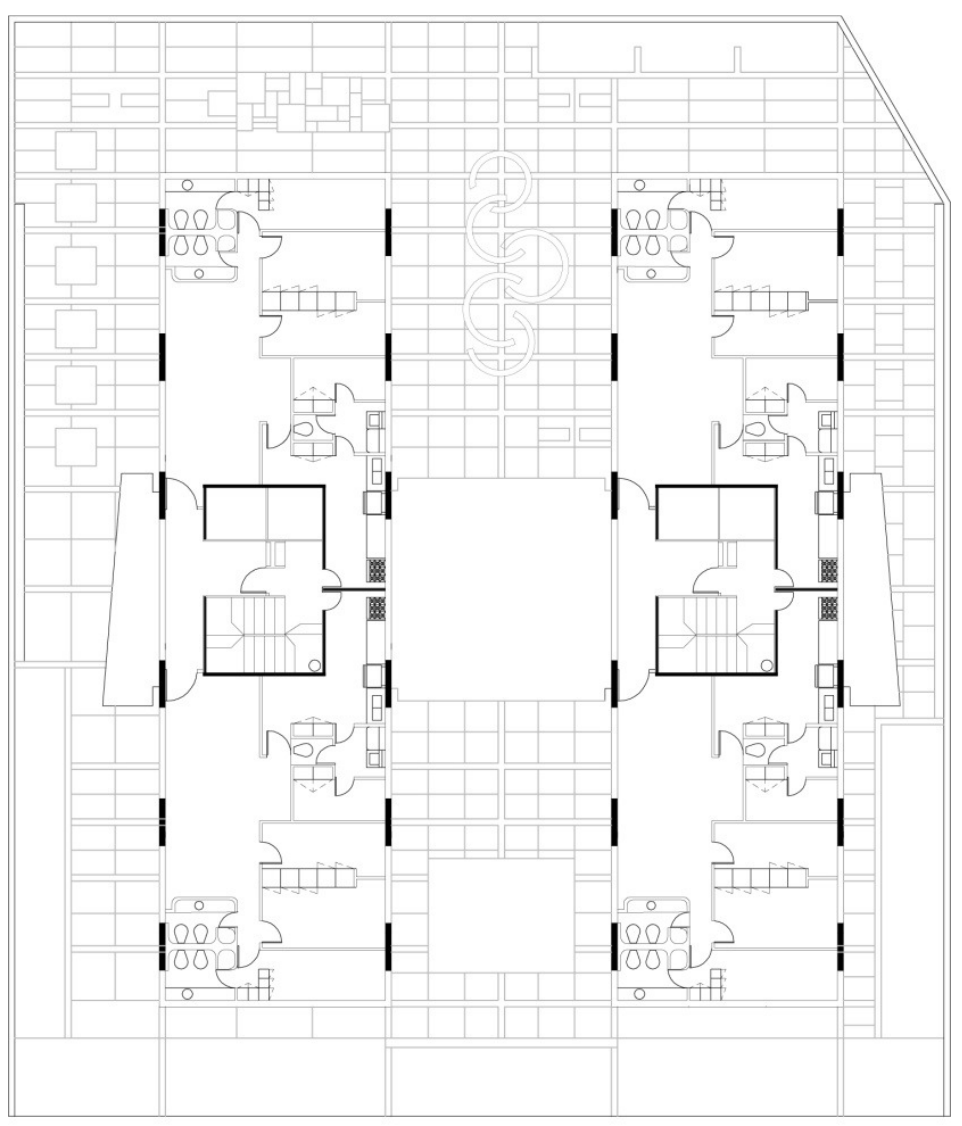

Planta Pavimento Tipo 


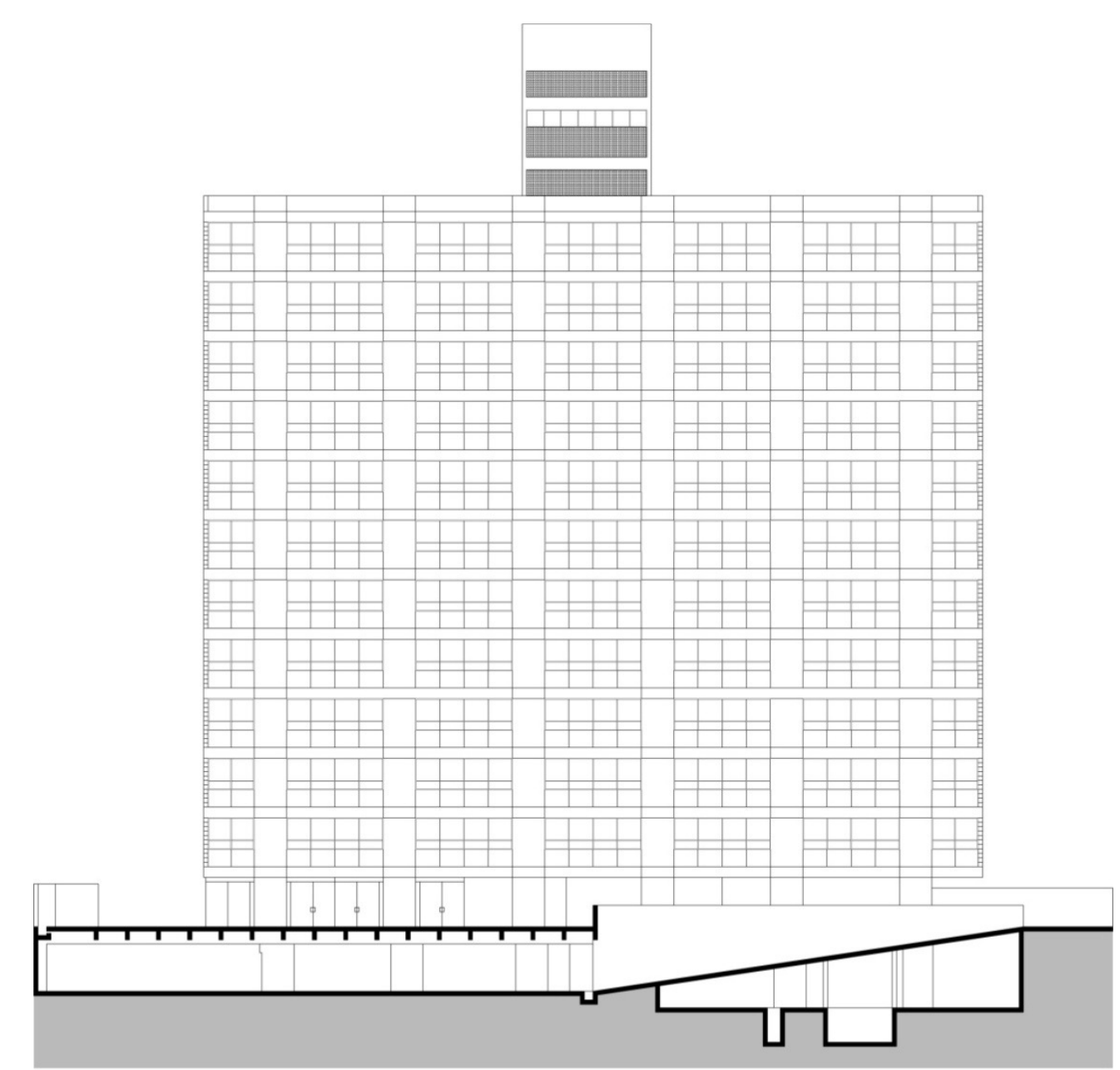

Q

Elevação Longitudinal 


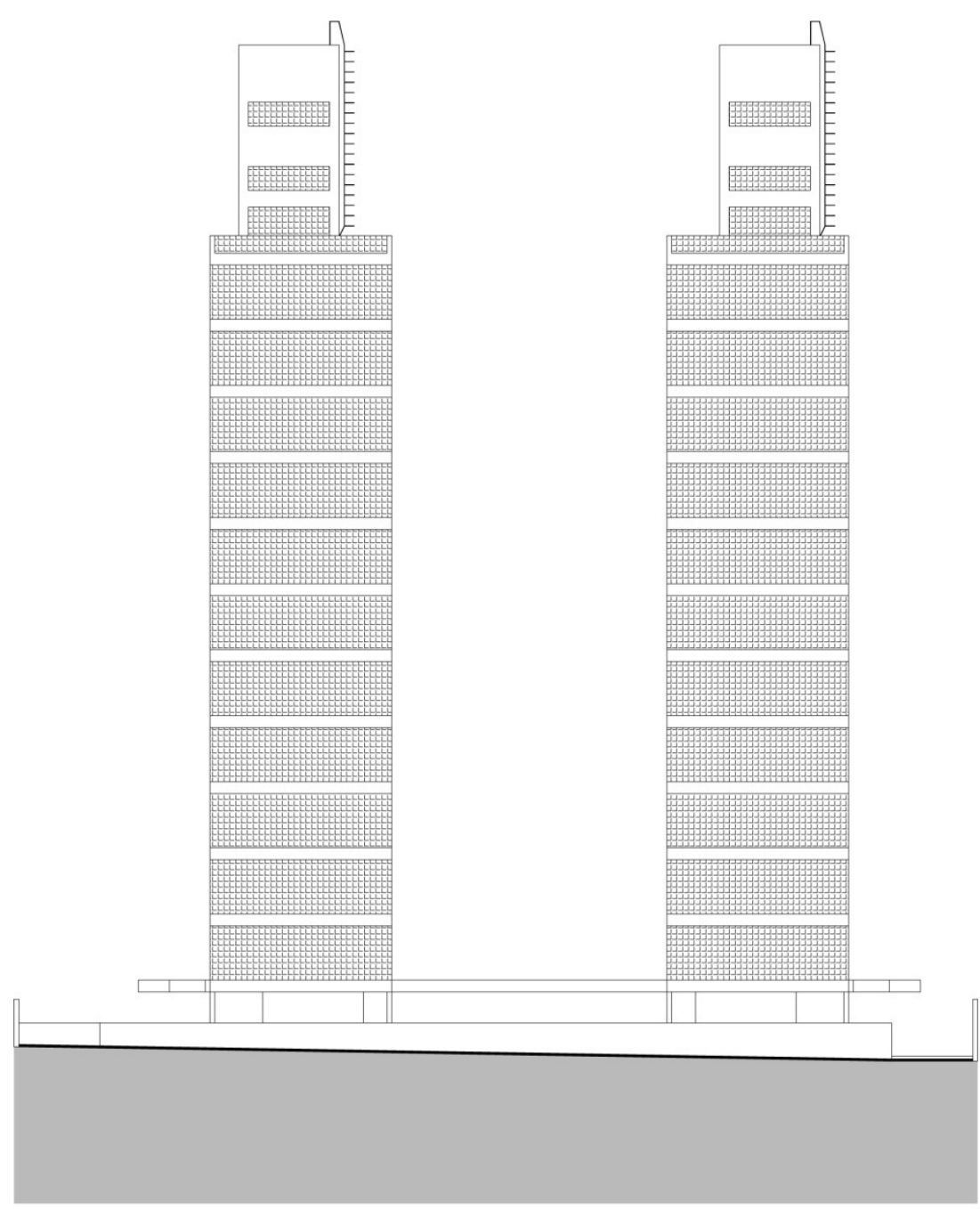

Elevação Transversal - Rua 
Ainda em 1970, Sanovicz projetou outro edifício com sistema construtivo semelhante. Desta vez tratouse de edifícios com apartamentos de dois quartos. O edifício é uma composição de dois blocos paralelos, com circulação vertical independente que serve a ambos. Cada bloco possui dois apartamentos. Executado duas vezes, uma no centro de São Bernardo do Campo - Edifício Olympia com 10 pavimentos e embasamento comercial e outra em São Paulo, na Granja Julieta, mais precisamente na Rua Me. Rita Amada de Jesus, 79 - Edifício Granja Julieta [Figuras 25, 26, 27 e 28].

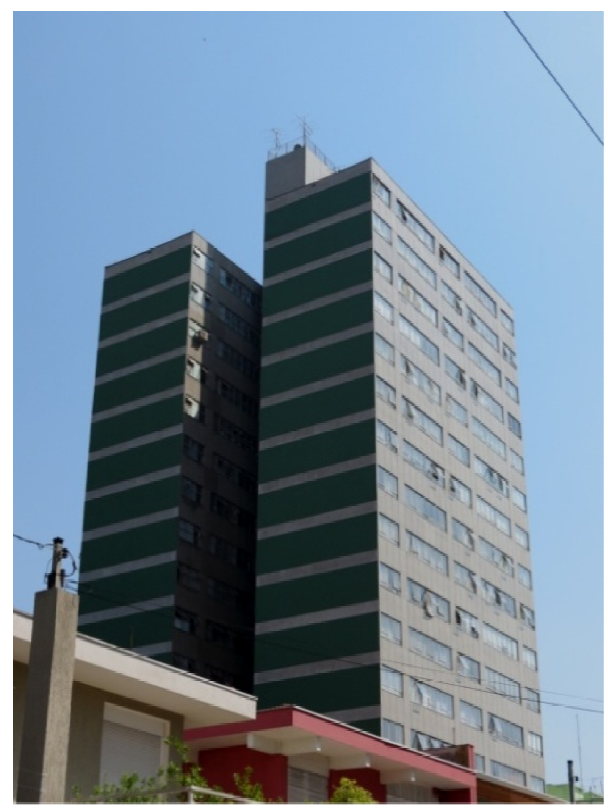

Figura 25 - Edifício Granja Julieta - 1971 Foto - Priscylla Lima

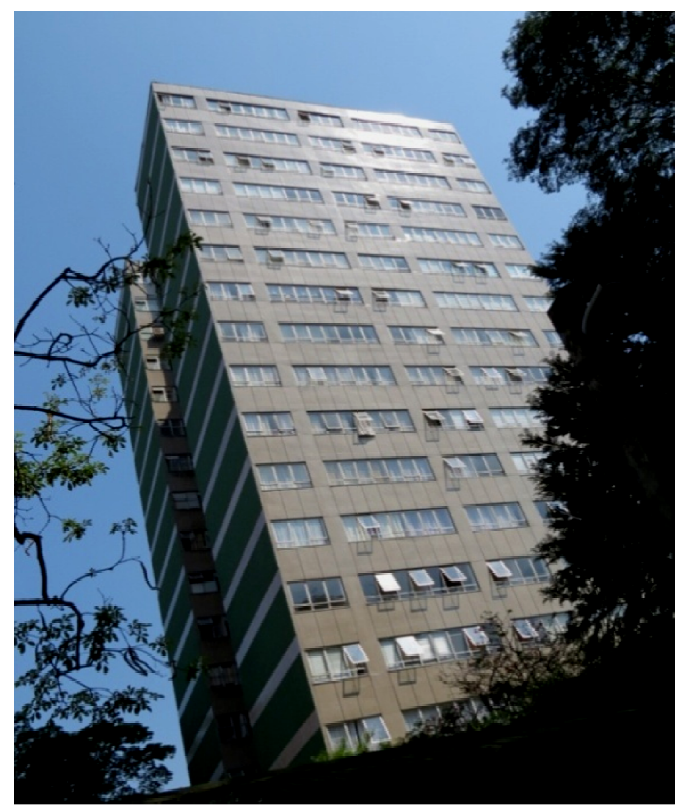

Figura 26 - Edifício Granja Julieta - 1971. Foto - Juliano Barros 


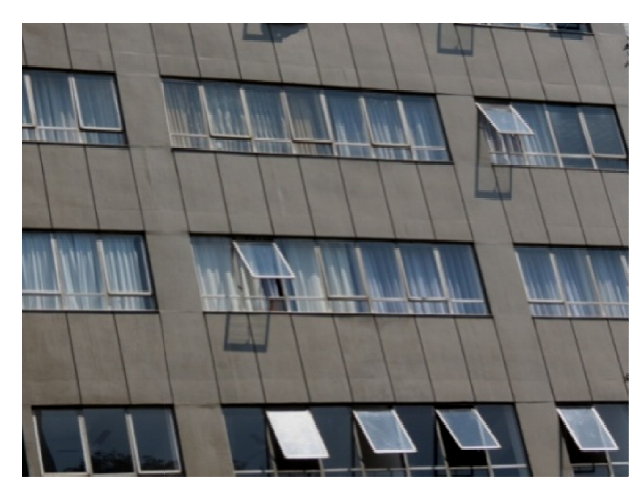

Figura 27 - Edifício Granja Julieta - 1971 Foto - Priscylla Lima

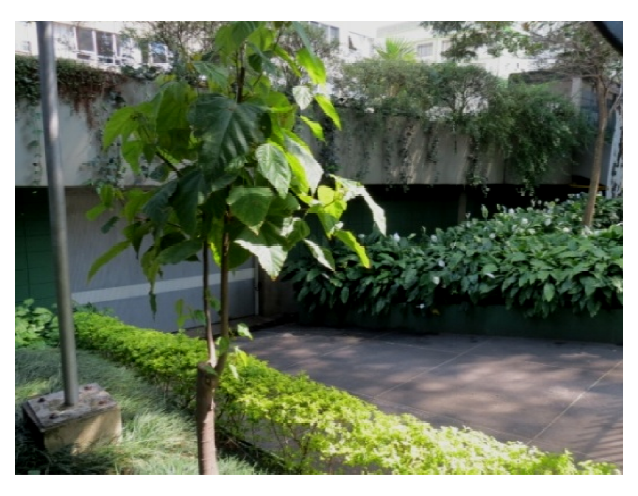

Figura 28 - Edifício Granja Julieta - 1971. Foto - Priscylla Lima

As lâminas estão implantadas de modo que sala e quartos se abrem para a vista e os serviços se voltam para dentro. A circulação vertical central configura um volume quase anexo, com um corredor que acessa os apartamentos.

O princípio construtivo é o mesmo do Modular: fachadas longitudinais definidas por pilares e vigaspeitoril em concreto, vãos preenchidos com caixilhos e empenas laterais sem aberturas, com vigas em balanço em concreto aparente e vedação em blocos de concreto. Seu desenho, entretanto, contém diferenças em relação ao Modular. 0 vão no sentido transversal é de 8,00m Os pilares não seguem uma modulação tão regular e são também menos alongados e engrossados para dentro do apartamento.

Na elevação longitudinal, a marcação da estrutura e a modulação dos caixilhos são menores, e o edifício é mais estreito, o que lhe confere um caráter mais vertical. 
PROJETO EDIFÍCIO

GRANJA JULIETA

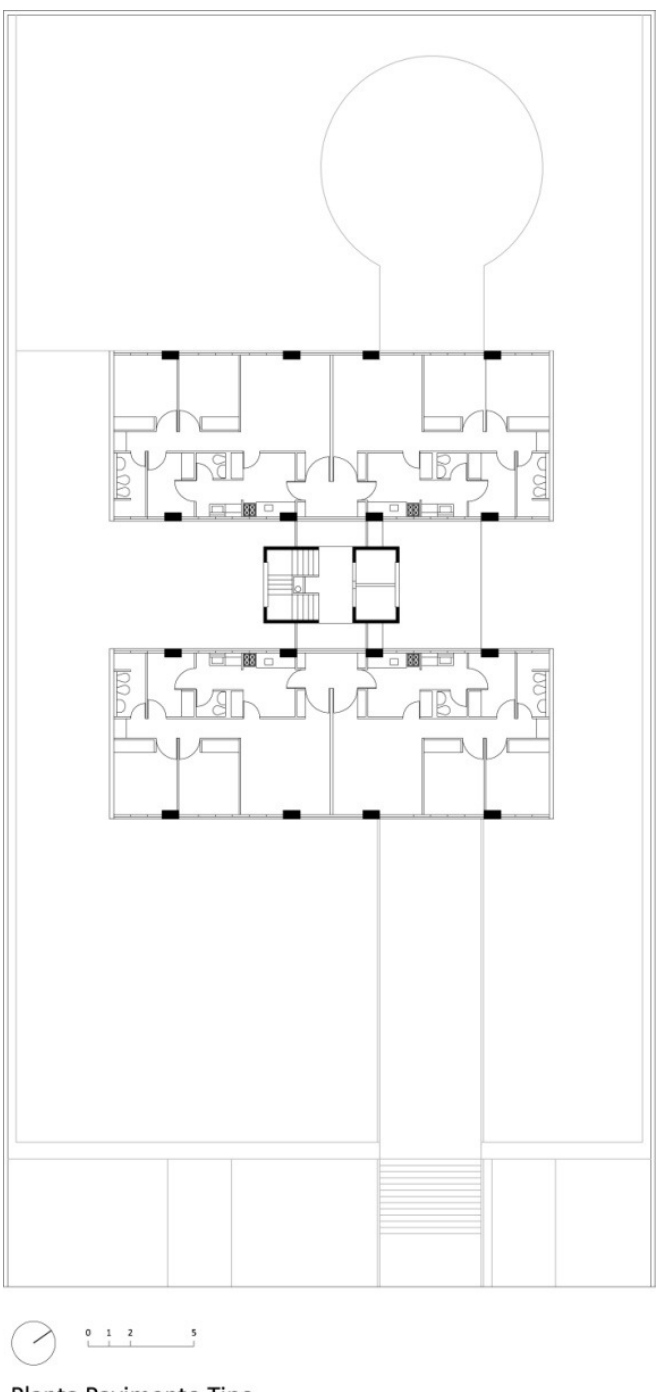

Planta Pavimento Tipo

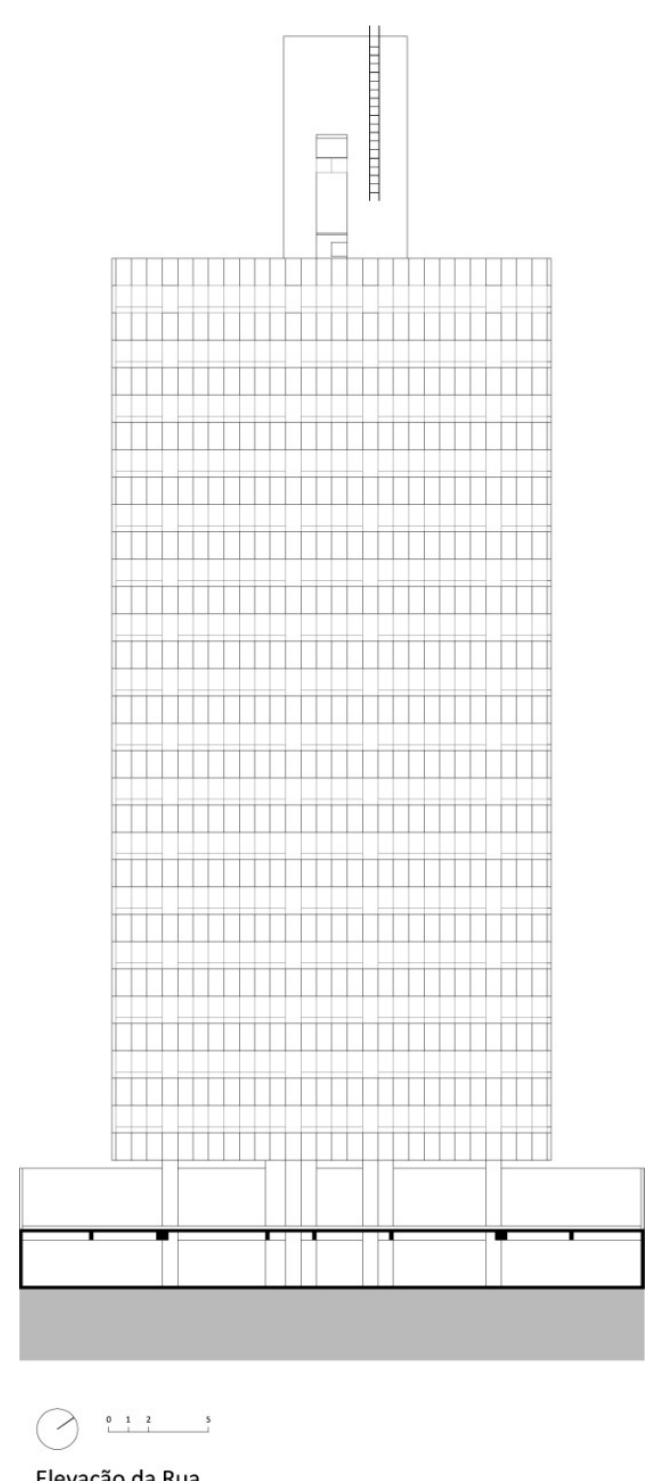

Elevação da Rua 


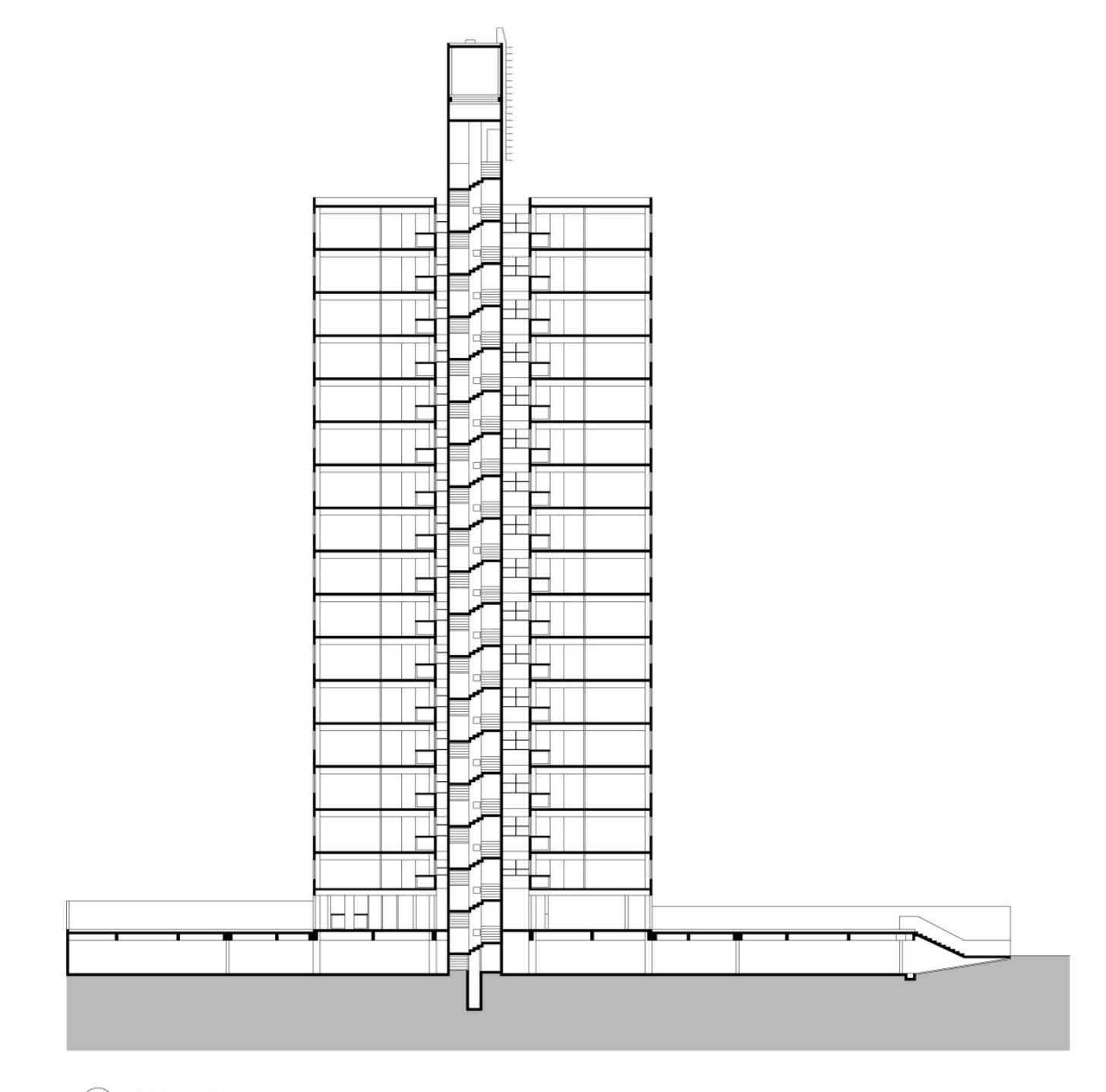


Os edifícios Modulares de onze pavimentos foram posteriormente adaptados para uma segunda etapa de produção. São eles: Modular Lambada I e II no bairro do Paraíso, São Paulo, Modular Omicron no bairro do Itaim Bibi, São Paulo; Modular Eta, no bairro de Vila Mariana, São Paulo; Modular Ômega I, II, III e IV no bairro de Campo Belo, São Paulo; Modular Sigma I e II e Modular Vega, ambos no bairro de Perdizes, São Paulo. Apesar de manter a planta quase idêntica, o sistema construtivo distanciou-se muito da proposta original. Diferem dos edifícios anteriores por apresentar pilares de concreto aparente dispostos perpendicularmente ao sentido da fachada, com vigas de menor altura, não sendo mais o fechamento longitudinal do edifício definido pela própria estrutura, mas por alvenaria de bloco de concreto aparente, com a diminuição dos vãos completados por caixilhos de alumínio.

Uma razão técnica utilizada para justificar esta alteração relaciona-se principalmente à questão da infiltração da água que ocorreu nas juntas da estrutura com a vedação em blocos de concreto. A alteração estrutural do projeto eliminou este balanço. Entretanto, mais que o motivo técnico, a substituição das empenas de concreto por alvenarias de bloco para economizar no custo parece uma justificativa mais razoável. Esta decisão partiu provavelmente da construtora, levando-se em conta que a nova estrutura adotada no edifício de Sanovicz foi utilizada em outros prédios da Formaespaço ${ }^{16}$.

O último edifício seguindo o sistema estrutural dos Modulares é o edifício Modulinho. Este prédio também foi construído com a estrutura modificada e pilares perpendiculares à fachada. Em planta

\footnotetext{
${ }^{16}$ Dados extraídos das entrevistas com o arquiteto João Honório de Mello Filho para a dissertação de mestrado IMBRONITO, Maria Isabel "Três Edifícios de Habitação para a Formaespaço: Modulares, Gemini e Protótipo". FAU-USP. São Paulo, 2003.
} 
corresponde aos dois Modulares de dois quartos que ajudam a compor o conjunto construído na Rua Vieira de Moraes, no Campo Belo, junto a dois Modulares de três quartos dispostos em linha [Figura 29].

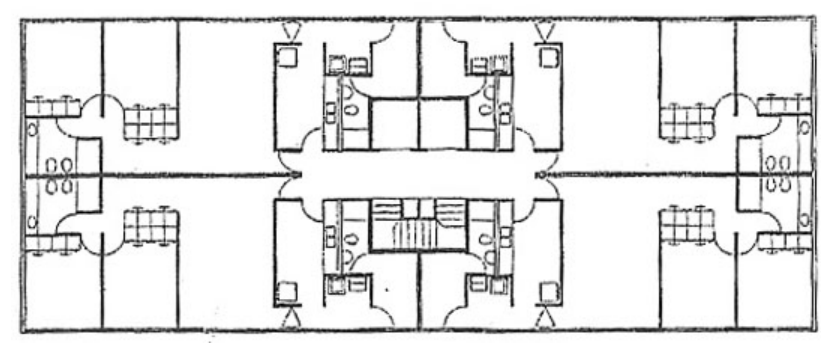

Figura 29 - Planta Edifício Modulinho

Fonte - Acervo Abrahão Sanovicz - Biblioteca FAU USP.

Em depoimento, o arquiteto diz que teria avançado sua pesquisa no sentido de incorporar componentes aos edifícios $^{17}$. Seu objetivo era oferecer um edifício com maior ou menor número de equipamentos, que compara a um automóvel, ao qual se acoplam acessórios. Estes estudos foram interrompidos por conta do fim da Formaespaço.

A apreciação dos edifícios Modulares e a descrição de sua construção evidenciaram a sobreposição do desenho industrial e arquitetura no trabalho de Abrahão Sanovicz. Revelam ainda que o desenvolvimento do sistema construtivo não se resolve enquanto condição desvinculada da arquitetura. Conforme disse o arquiteto:

${ }^{17}$ Entrevista de Abrahão Sanovicz à pesquisadora Catherine Gati. CCSP, ibidem, entrevista em 19/08/1987, pp. 23-25. 
As técnicas e a tecnologia são os meios e não os fins em arquitetura. Tanto as técnicas quanto os materiais construtivos são meios e estão embutidos no projeto, fazendo parte da concepção inicial, do ato de projetar e não surgindo a posteriori. A solução ao problema apresentado, o projeto, tem que ser por inteiro, de uma só vez ${ }^{18}$.

${ }^{18}$ Entrevista Abrahão Velvu Sanovicz, resenha Lucinda Ferreira Prestes. Cadernos de Arquitetura FAU-USP, v.1, São Paulo, 2001, p.81. 


\subsection{FORMAESPAÇO}

E 0 ARQUITETO

EDUARDO DE ALMEIDA
Ao conhecer a obra do arquiteto Eduardo de Almeida, nota-se o método utilizado pelo arquiteto para projetar. O predomínio do particular sobre o geral, fato que se acentua na medida em que projeta a partir do programa, do cliente, das especificidades, dos materiais, do lugar. Ainda assim, o princípio organizativo com que formula as questões espaciais, programáticas e construtivas fez do Edifício Gemini, que foi idealizado como projeto único, um edifício possível de ser reproduzido.

Ao projetar, faz parte do processo de criação do arquiteto, um sistema de medidas destinado a resolver construção e programa. Para a modulação estrutural adequada, aplica-se o princípio da divisão ou composição do módulo para dimensionamento dos espaços. Para a ordenação do sistema estrutural insere-se o programa, ao mesmo tempo em que este define dimensão, arranjo e número de módulos. Medidas mínimas podem ser adotadas para circulação e serviços, e dimensões mais generosas para o espaço servido, seguindo uma lógica que permite uma maior complexidade na articulação dos programas.

Este rigor possibilita grande liberdade compositiva, proporcionada pela clareza ao lidar com as regras do ato de projetar. A disposição da estrutura, a definição dos espaços e a composição de planos e aberturas revelam a permanente busca pela evidência do desempenho de cada uma das partes da construção. O projeto resulta numa unidade proporcionada pela estrutura, que se estende ao detalhamento e à escolha dos materiais. A independência dos elementos construtivos permite o aprofundamento do desenho de cada uma das partes, que se remetem ao todo através da articulação 
dos componentes e da definição de alinhamento e proporções. O detalhamento, segundo o arquiteto, é consequência do desenvolvimento do projeto e a ele se incorpora ${ }^{19}$.

O primeiro projeto que Eduardo de Almeida fez para a Formaespaço foram os Edifícios Gemini I e II, em 1969. O Gemini foi inicialmente concebido para uma situação específica, e só depois adaptado para a produção em série ${ }^{20}$. Implantados sempre aos pares, foram repetidos mais duas vezes: edifícios Coronet I e II e Lark I e II.

Sem a preocupação explícita em propor o edifício como um sistema de montagem, pode-se dizer que o arquiteto assume uma abordagem semelhante à de Abrahão Sanovicz nos edifícios Modulares. Almeida compartilha com Sanovicz uma aproximação com o desenho industrial ${ }^{21}$. A arquitetura do Gemini, em sua concepção inicial, comportou princípios organizativos que, posteriormente, permitiram a sua repetição. A racionalização do projeto não inclui apenas a redução de elementos e etapas construtivas. O projeto é definidor dos espaços e, ao mesmo tempo, organiza o ato de construir. Identificam-se os elementos construtivos, compondo-se para se tornarem a expressão da arquitetura. A estrutura, os fechamentos sem revestimentos e as aberturas definem por si só, composição, cor, textura, ritmo e

\footnotetext{
${ }^{19}$ Colocações a partir de conversas com o arquiteto, ao procurar descrever seu método de projeto. A frase de Almeida, "o melhor detalhe é aquele que não se vê", ilustra como o detalhe deve se incorporar ao projeto. Dados extraídos da dissertação de mestrado IMBRONITO, Maria Isabel - "Três Edifícios de Habitação para a Formaespaço: Modulares, Gemini e Protótipo". FAU-USP. São Paulo, 2003.

${ }^{20} \mathrm{~A}$ comparação entre os edifícios Gemini e os edifícios Lark e Coronet são abordados por Eduardo de Almeida em sua tese de doutorado. Ver ALMEIDA, Eduardo. “Habitação: consumo, produto, projeto” Tese de doutorado. FAU-USP. São Paulo, 1972.

${ }^{21}$ Eduardo de Almeida formou-se pela FAU-USP em 1960, estudou desenho industrial na Itália em 1962 e lecionou desenho industrial na FAU USP, antes de se tornar professor de projeto de edificações.
} 
ordenação das fachadas. Novamente, os procedimentos da obra estão previstos no desenho, pois se trata de uma arquitetura que considera o ato de fazer.

\section{EDIFÍCIO GEMINI I e II}

No Gemini [Figura 30], o terreno de esquina apresenta leve inclinação, com a Rua Graúna em nível e a Rua Tuim em declive, o que sugeriu a implantação da garagem em dois níveis, com acessos diretamente pela Rua Tuim. A laje que cobre a garagem desenha o espaço livre do térreo, aberto e um pouco elevado para a Rua Graúna. O desnível do subsolo comparece novamente no chão da praça do térreo, com uma parte mais preservada ao fundo, ligeiramente rebaixada que abriga o playground [Figura 31].

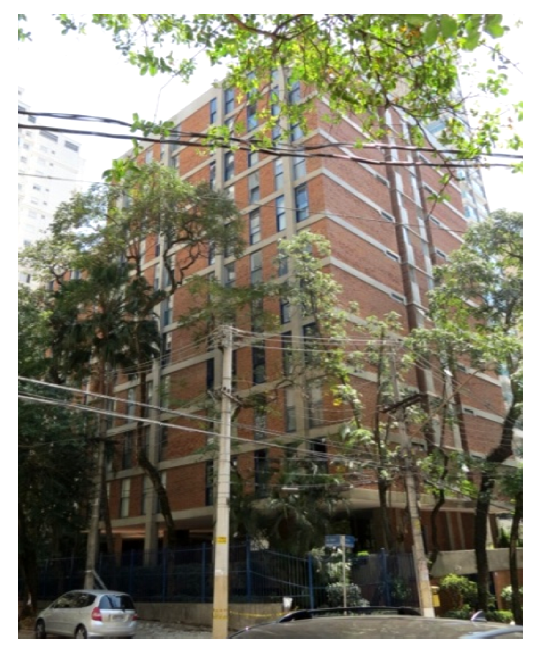

Figura 30 - Edifício Gemini, São Paulo - 1969 Foto - Priscylla Lima

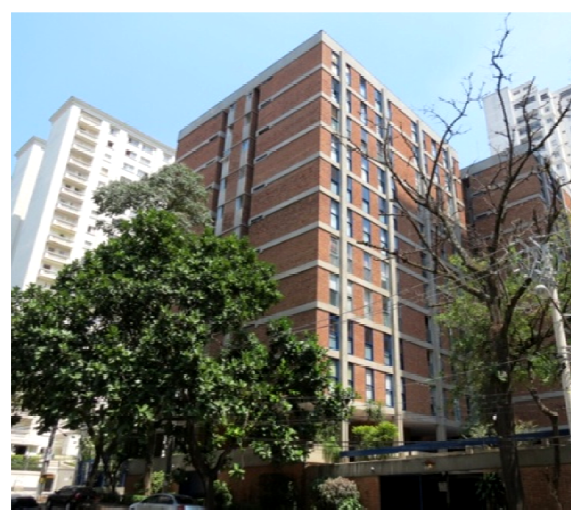

Figura 31 - Edifício Gemini, São Paulo - 1969. Foto - Priscylla Lima 
Esta laje faz o embasamento de onde emergem as duas torres. Muito próximas e levemente deslocadas, a mais saliente demarca a esquina. A outra surge depois, recuada, como uma surpresa no percurso confirmando a primeira. Os edifícios com dez pavimentos e quatro apartamentos por andar, assim como os Modulares de Sanovicz, apresentam coeficiente de aproveitamento menor que o previsto por lei, mas de acordo com a opção da construtora por lotes mais baratos e afastados.

Os edifícios possuem estrutura regular composta por quatro linhas de pilares de concreto, aparentes nas elevações que contêm quarto e sala espaçados a cada 5,50m, com balanço nas quinas. Os pilares mantém a secção constante, ocorrendo variação apenas na ferragem, para permitir o reaproveitamento das formas. No outro sentido do edifício, o vão é variável e os pilares são recuados da fachada.

Na disposição do programa da unidade configuram-se o estar, os quartos e os serviços, sendo o acesso feito através de um vestíbulo que conecta os três setores. Além da independência de circulação, a planta concentra áreas molhadas e apresenta flexibilidade quanto às divisões de quartos e sala. Estes se abrem para frente e fundo do terreno, onde o espaço livre é desenhado pelas praças. Os serviços posicionam-se na lateral das torres, em que o recuo é menor. A disposição das aberturas de quarto e sala, e a implantação deslocada das torres em relação aos serviços, garantem a privacidade dos apartamentos. 
No Gemini, a construção visava apenas a organização do sistema tradicional. Assim, foram utilizadas técnicas mais artesanais, como o tijolo de barro como material de vedação [Figuras 32 e 33]. O tijolo de barro aparente, irregular na forma, cor, textura e pobre na qualidade de fabricação, além de instável no comportamento físico, forma o contraste com a volumetria pura das torres. Por não apresentar medidas padronizadas, é seu assentamento absolutamente artesanal que permite a adaptação aos vãos da estrutura. $\mathrm{O}$ arquiteto pôde assumir então, uma modulação rigorosa [Figura 34]. 0 edifício nasce a partir de uma retícula de $50 \times 50 \mathrm{~cm}$.

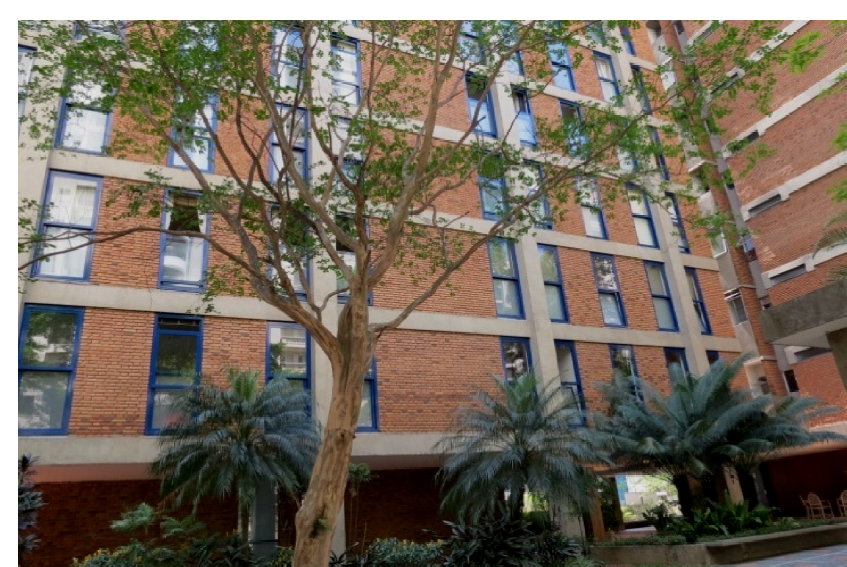

Figura 32 - Edifício Gemini, São Paulo - 1969. Foto - Priscylla Lima

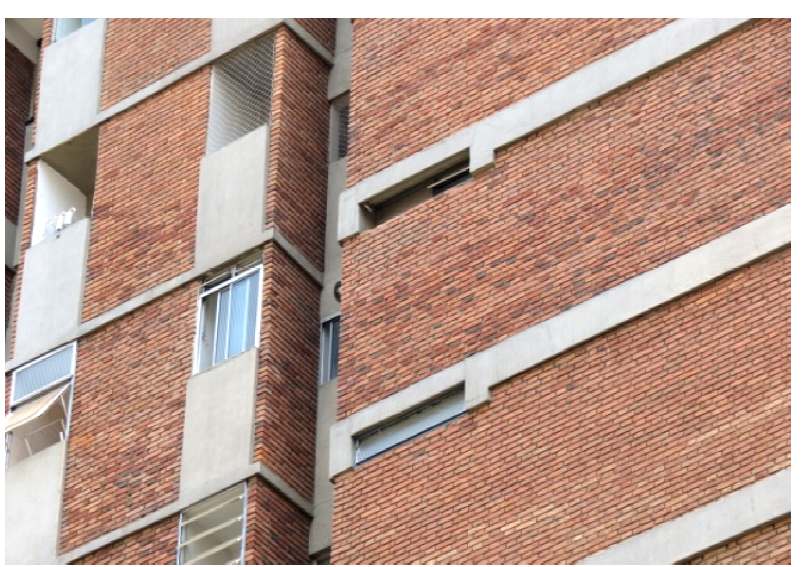

Figura 33 - Edifício Gemini, São Paulo - 1969. Foto - Priscylla Lima 


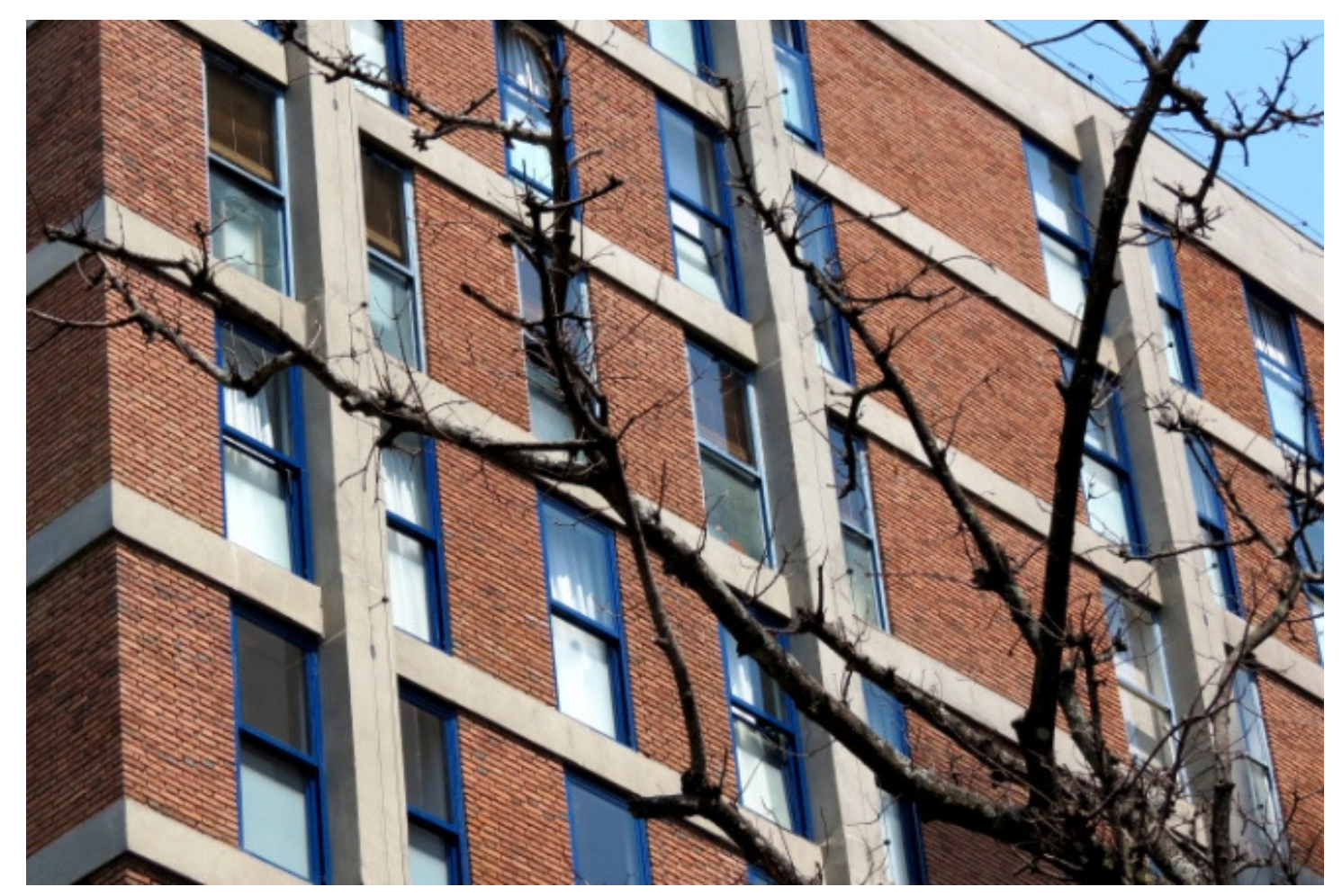

Figura 34 - Edifício Gemini, São Paulo - 1969. Foto - Priscylla Lima 
PROJETO

GEMINI I E II

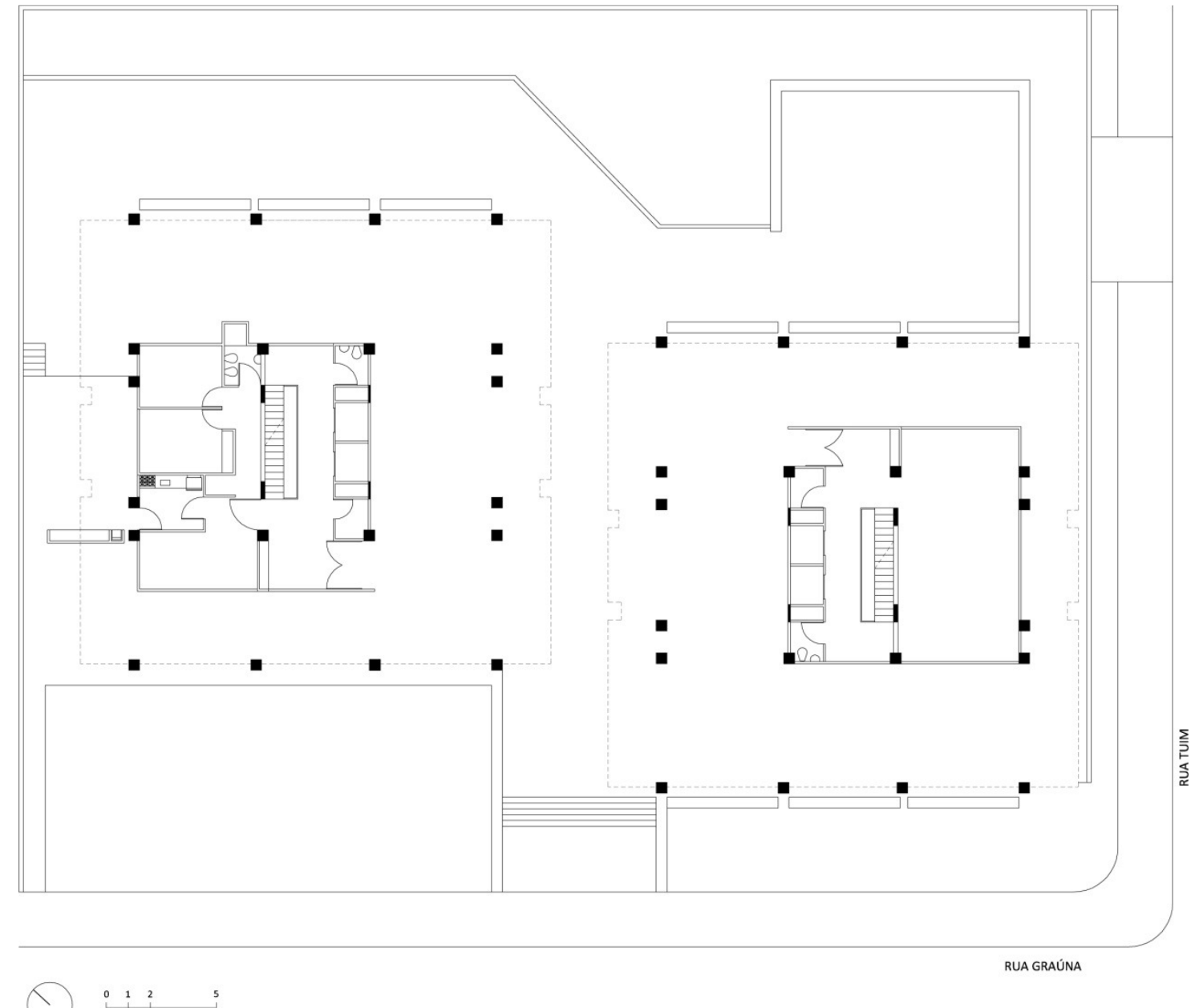

Planta Pavimento Terreo 


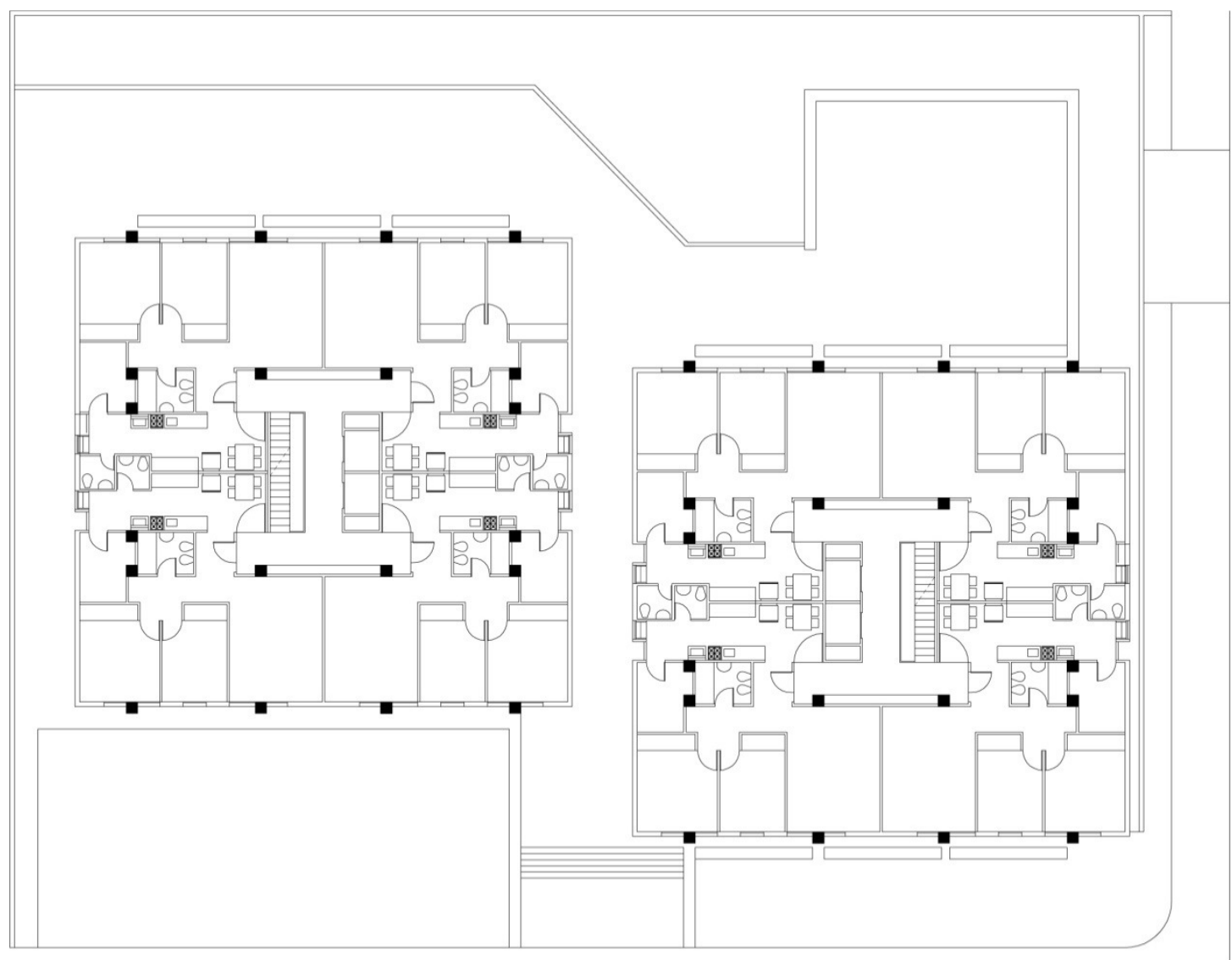

( 012

Planta Pavimento Tipo 


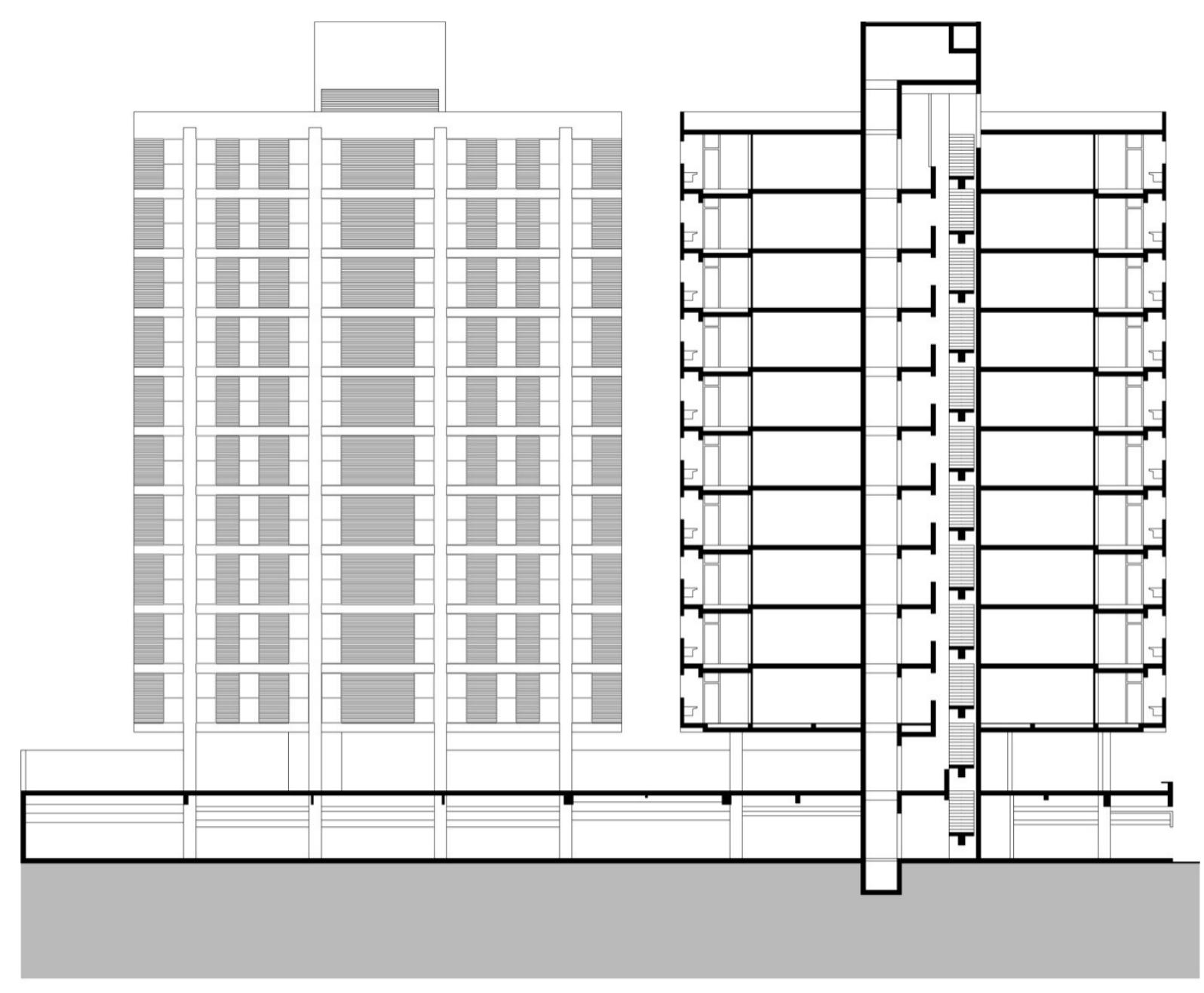

$\bigodot_{\text {Corte Longitudinal }}$ 


\section{EDIFÍCIOS CORONET E LARK}

A partir do grande sucesso de vendas, o Edifício Gemini foi modificado por solicitação da construtora para ser produzido em série. Segundo o arquiteto em termos de metodologia, foi de valia a experiência dos Modulares, do arquiteto Abrahão Sanovicz, e também o fato do Gemini servir como modelo construído para os novos edifícios ${ }^{22}$. Nos edifícios Coronet e Lark [Figuras 35 e 36], objetivo era racionalizar ainda mais a construção. Foram então revistos planta, estrutura e materiais.

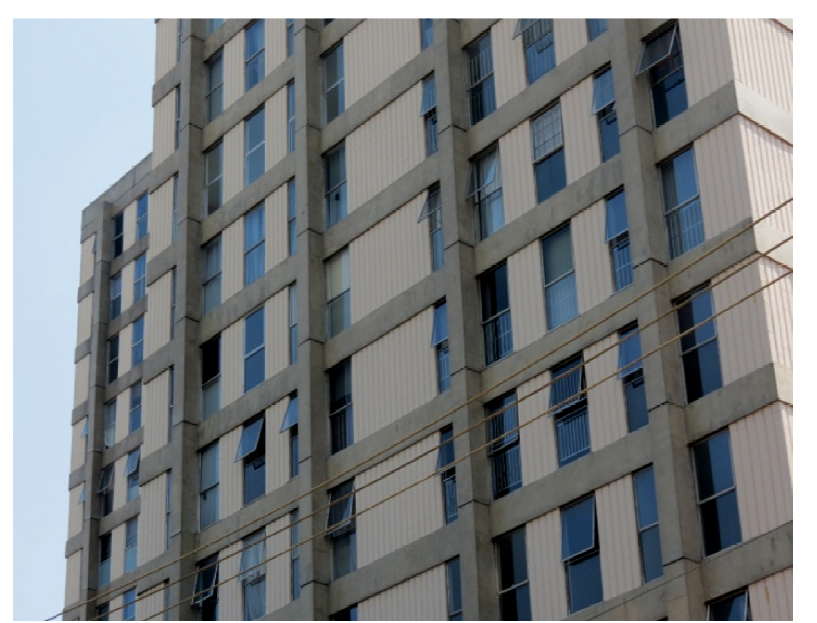

Figura 35 - Edifício Coronet, São Paulo - 1973

Foto - Priscylla Lima

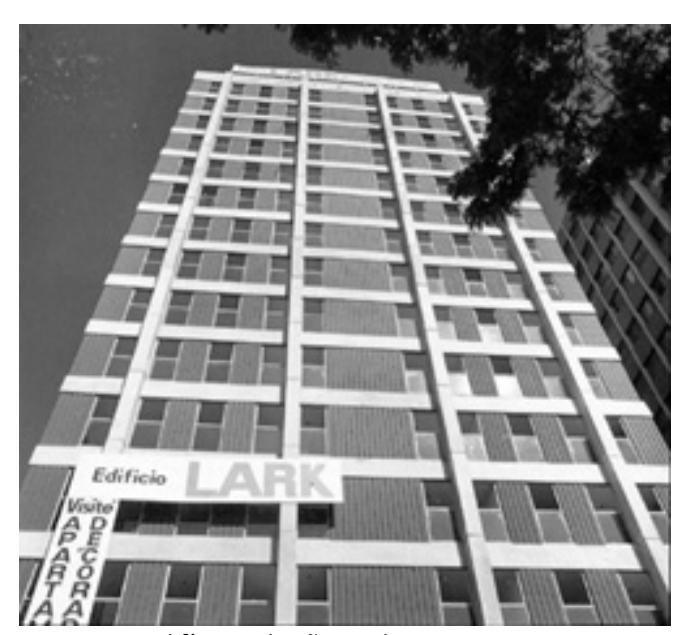

Figura 36 - Edifício Lark, São Paulo - 1973

${ }^{22}$ Almeida, op. cit., p.25 
A planta básica foi mantida. Apenas as áreas molhadas foram redesenhadas para concentrar prumadas: as instalações da cozinha, área de serviço e banheiro posicionam-se a uma única parede hidráulica, e o mesmo acontece com os banheiros de serviço de dois apartamentos justapostos.

A estrutura modificou-se e se tornou mais periférica, ficando aparente nas quatro elevações, com o núcleo de circulação vertical funcionando como enrijecimento do sistema. O número de apoios final foi reduzido e as fôrmas racionalizadas. Manteve-se o balanço estrutural, resultando nos quatro cantos sem apoios.

Como alternativa ao tijolo de barro, foi inicialmente estudado um fechamento externo do edifício com painéis pré-fabricados de concreto com agregado leve e gesso na face interna. Este detalhe foi desenvolvido pelo arquiteto João Honório de Mello Filho e não se viabilizou. Segundo o arquiteto, estrutura de concreto moldada in loco não comporta o rigor necessário para a adoção de elementos pré-fabricados. Além disso, a instabilidade da economia brasileira desestimulou o investimento na préfabricação que exige uma continuidade do processo de produção uma vez que os custos iniciais são bem elevados ${ }^{23}$.

A vedação de tijolo foi então substituída pelo bloco de concreto, que apresenta maior rendimento na colocação. Os blocos foram especialmente produzidos para a Formaespaço, apresentando frisos

${ }^{23}$ Dados extraídos da entrevista com o arquiteto João Honório de Mello Filho, para a dissertação de mestrado IMBRONITO, Maria Isabel - "Três Edifícios de Habitação para a Formaespaço: Modulares, Gemini e Protótipo". FAU-USP. São Paulo, 2003. 
verticais marcados que definem a textura das paredes de vedação ${ }^{24}$. As alvenarias internas foram substituídas por painéis de gesso, mais leves, facilitando a execução da obra e aliviando estruturas e fundações. Foram adotados caixilhos de alumínio modulados, dispensando acabamento.

O edifício Coronet [Figuras 37 e 38] localizado no bairro de Santo Amaro, na esquina das Ruas Cancioneiro Popular e Bela Vista, possui implantação similar ao Gemini, mas com a disposição das torres invertidas. A laje de cobertura da garagem eleva a praça do térreo em relação ao nível da rua, e o desenho original não previu outro controle de acesso senão o desnível ajustado com taludes.

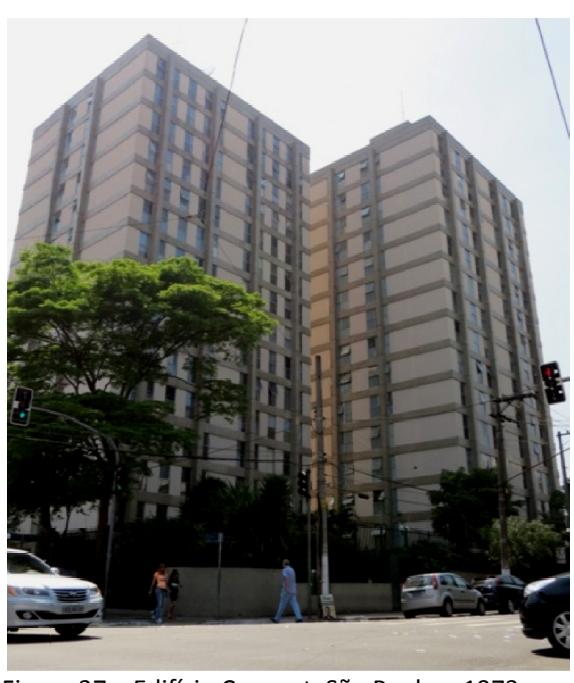

Figura 37 - Edifício Coronet, São Paulo - 1973 Foto - Priscylla Lima

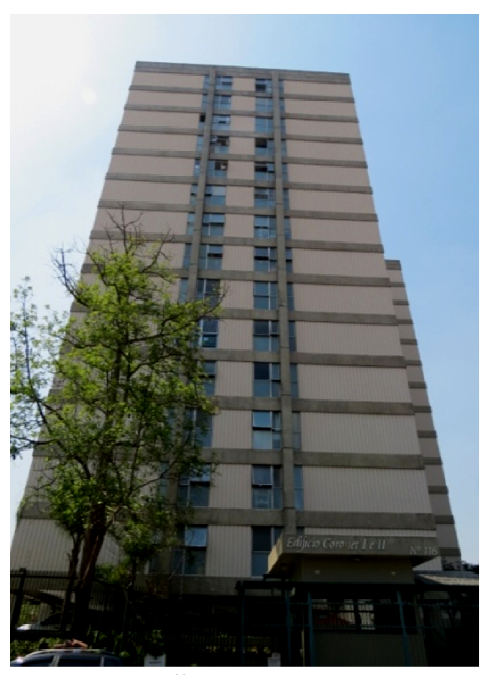

Figura 38 - Edifício Coronet, São Paulo - 1973. Foto - Priscylla Lima

${ }^{24}$ Dados extraídos da entrevista com o arquiteto Eduardo de Almeida, para a dissertação de mestrado IMBRONITO, Maria Isabel - "Três Edifícios de Habitação para a Formaespaço: Modulares, Gemini e Protótipo". FAU-USP. São Paulo, 2003. 
O edifício Lark [Figura 39], situado à Rua Monte Alegre, Perdizes, por sua vez, tem suas torres implantadas em terreno estreito e comprido de 30×100m, em aclive, com as torres dispostas uma atrás da outra. A laje que cobre a garagem e faz o desenho do térreo acompanha o desnível do terreno, subindo um patamar correspondente à altura da viga a cada 7,20m, medida do vão da estrutura.

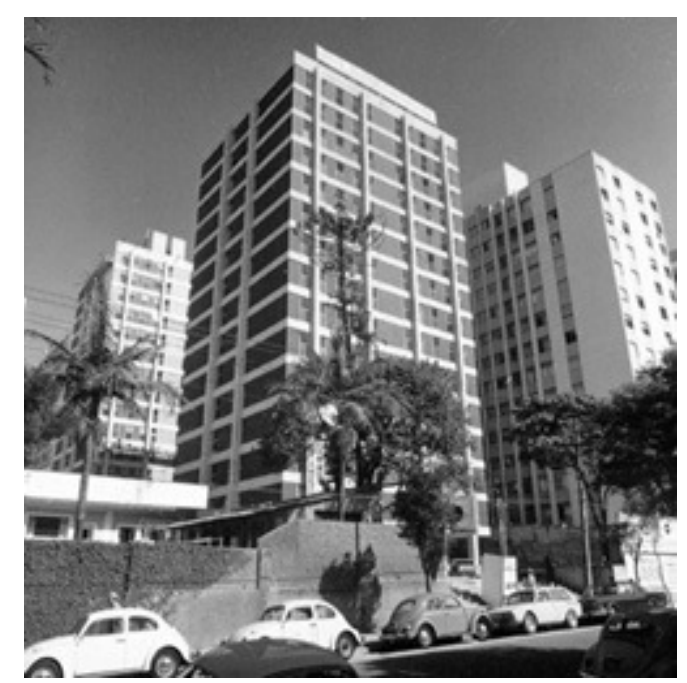

Figura 39 - Edifício Lark, São Paulo - 1973. 
PROJETO EDIFÍCIO

\section{CORONET I E II}

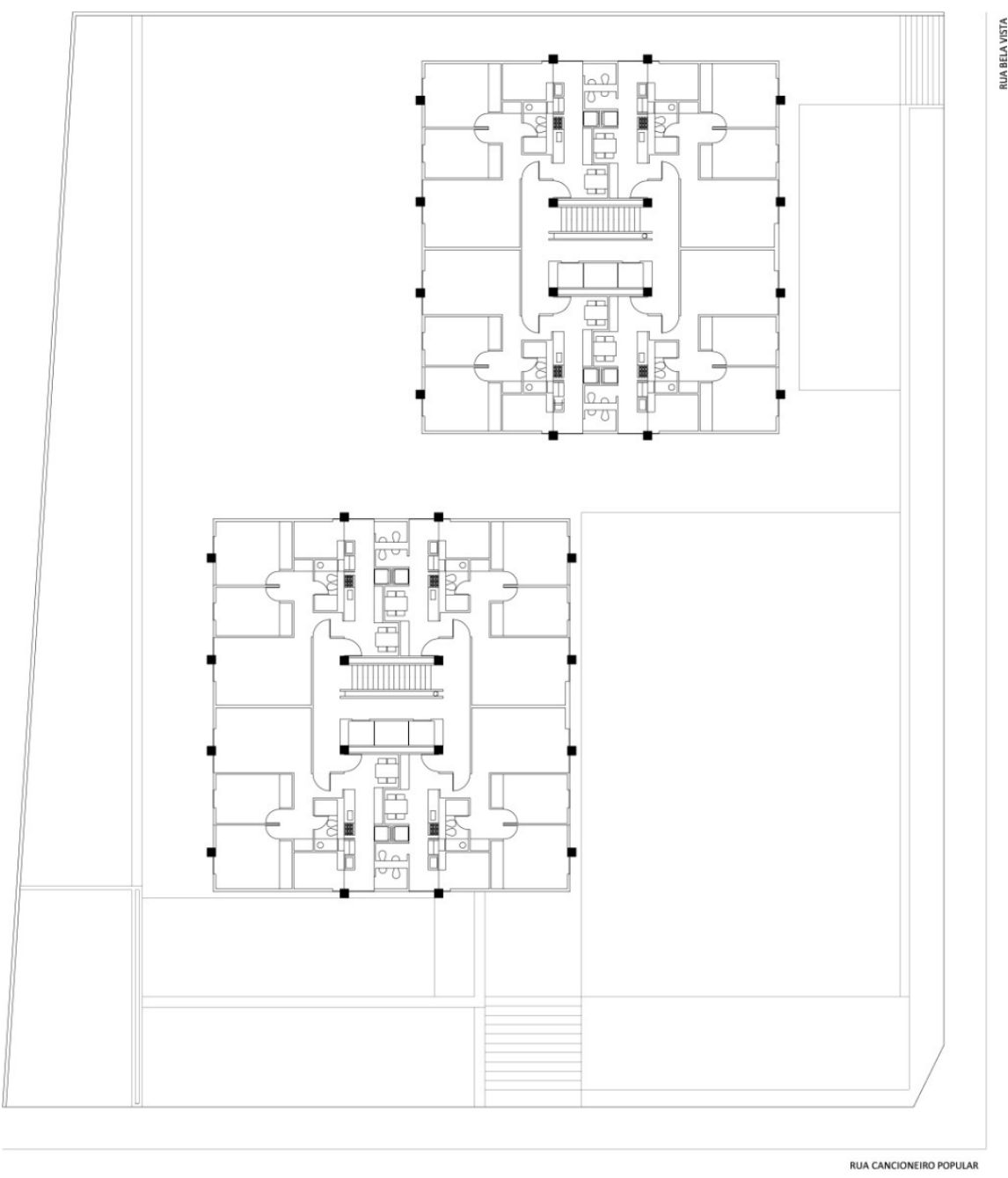

C rition 


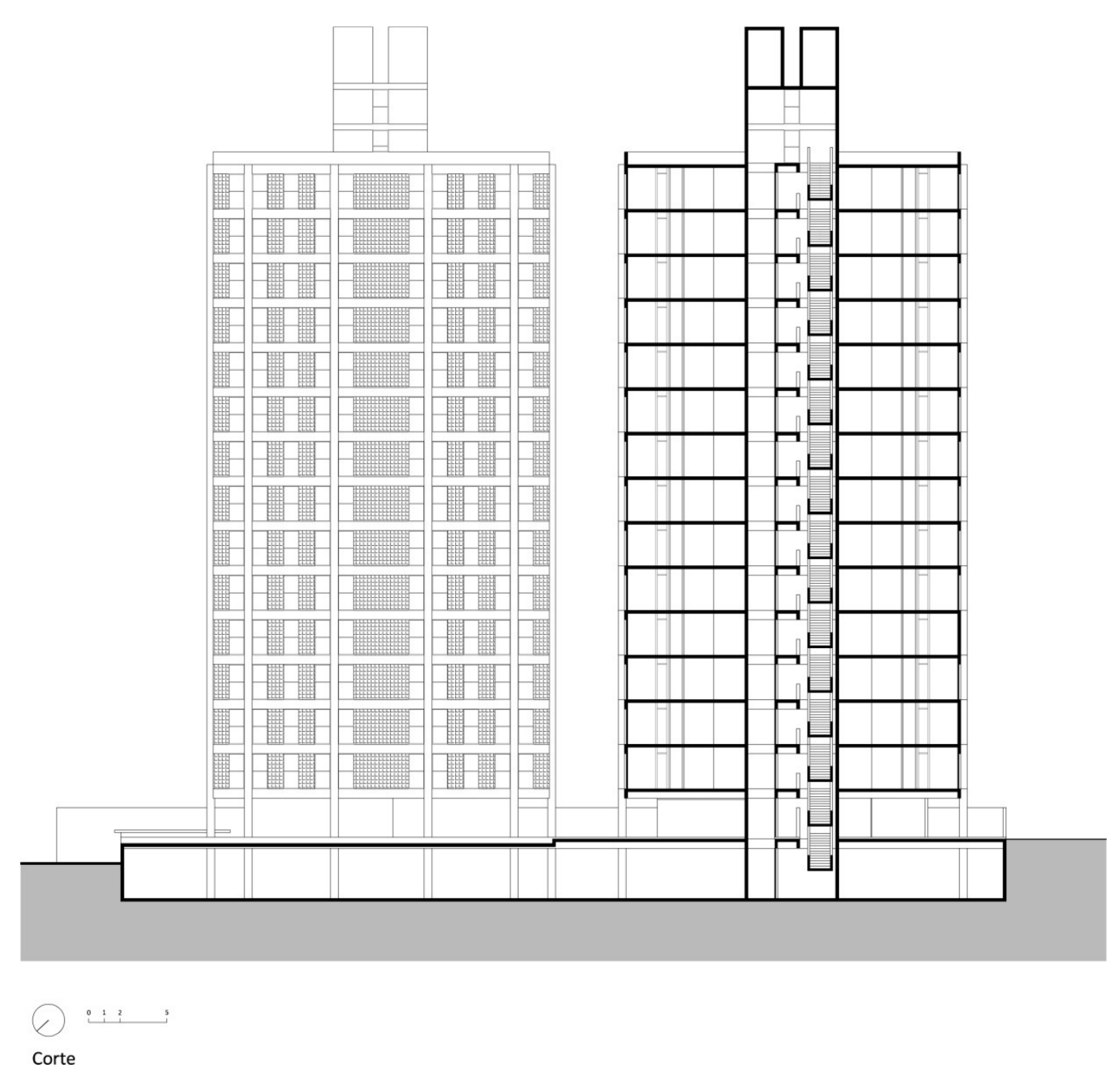


PROJETO EDIFÍCIO

LARK I E II

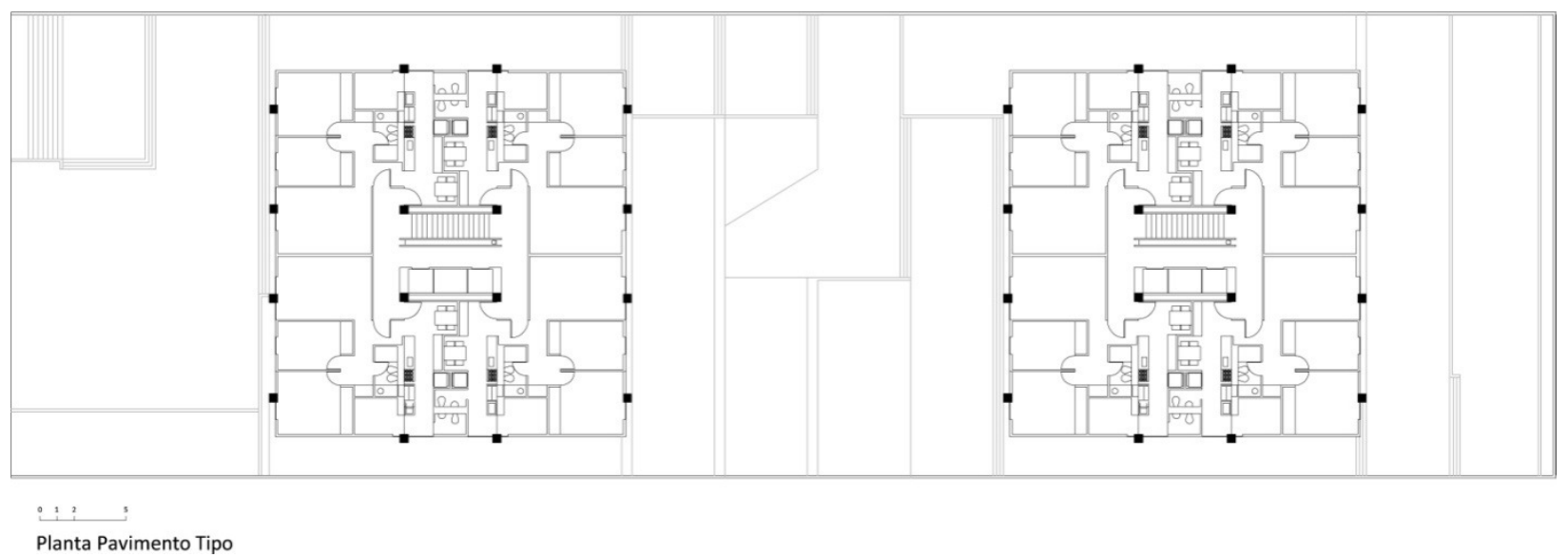




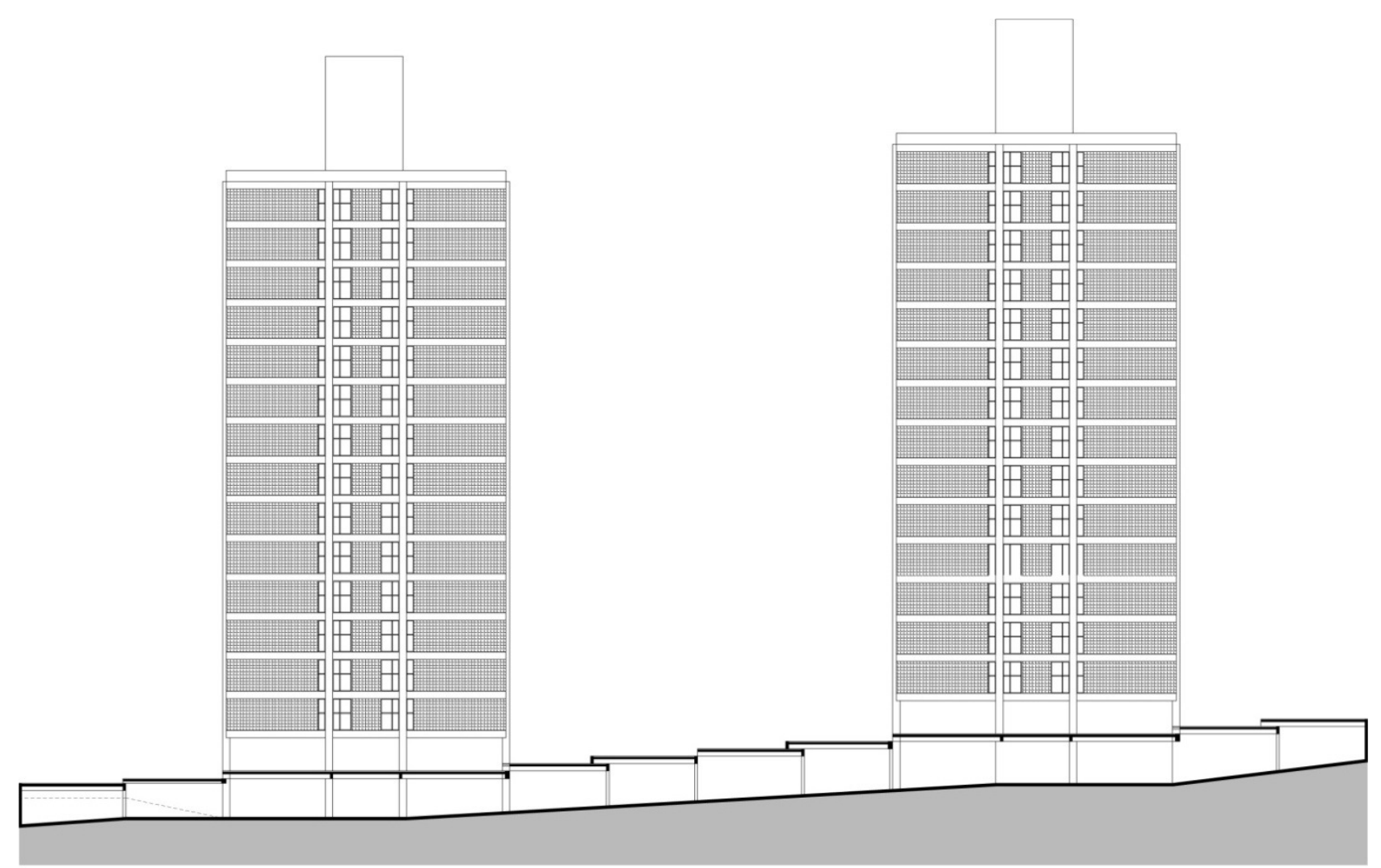

Corte Longitudinal 


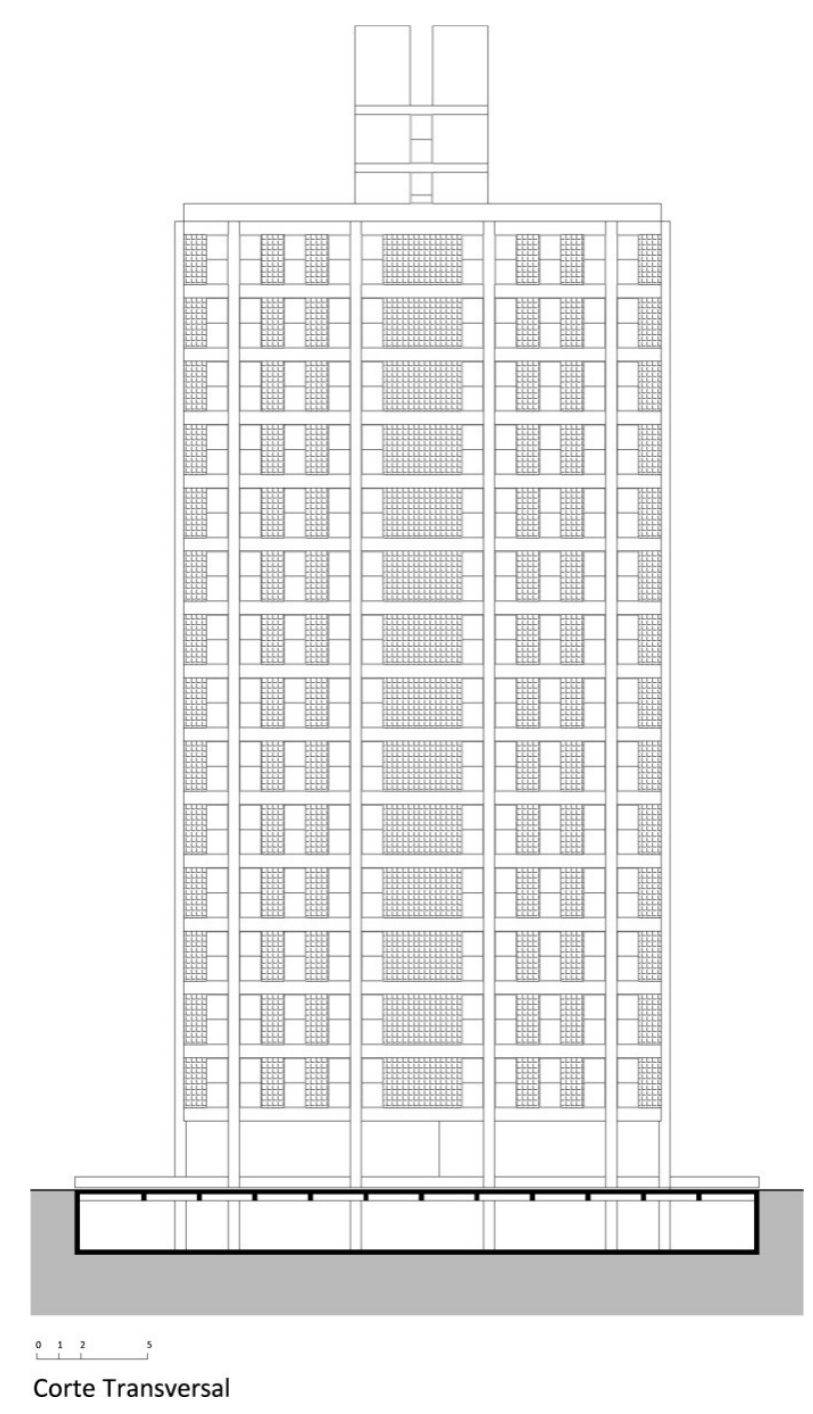




\subsection{FORMAESPAÇO}

E 0 ARQUITETO

PAULO MENDES DA ROCHA

Para Paulo Mendes da Rocha, a proposta da Formaespaço de fazer edifícios em série representou, principalmente, uma oportunidade de ensaiar a tipologia de habitação. Constata-se a partir de outros projetos que, para o arquiteto, o ensaio da tipologia supera o fato de projetar um edifício em série.

Reforçando os preceitos de Vilanova Artigas, Mendes da Rocha afirma que a habitação, em grande parte, é unidade básica de composição do tecido urbano, em que o extraordinário pode resultar seu conjunto. A casa isolada enquanto objeto extraordinário na cidade, não é desejada ${ }^{25}$. Para o arquiteto, o programa da habitação ampara-se na cidade. Consideram-se distâncias, fluxos, transportes, a escola, o trabalho, o clube, o mercado ${ }^{26}$.

Internamente, o programa da habitação atende às funções da vida moderna sendo, suporte para os modernos equipamentos. No mais, corresponde ao próprio espaço da habitação ${ }^{27}$. Este espaço configura a disposição espacial de um programa formulado coletivamente em São Paulo a partir dos anos 60 .

\footnotetext{
${ }^{25}$ Dados extraídos da entrevista com o arquiteto João Honório de Mello Filho, para a dissertação de mestrado IMBRONITO, Maria Isabel - "Três Edifícios de Habitação para a Formaespaço: Modulares, Gemini e Protótipo". FAU-USP. São Paulo, 2003.

${ }^{26}$ Ver depoimento gravado em vídeo. ROCHA, Paulo Mendes da. 16/10/97. São Paulo: Pini Vídeo, Museu da Casa Brasileira. Fita VHS [75min]

${ }^{27}$ Ver depoimento gravado em vídeo. ROCHA, Paulo Mendes da. 16/10/97. São Paulo: Pini Vídeo, Museu da Casa Brasileira. Fita VHS [75min]
} 
Paulo Mendes da Rocha projetou para a Formaespaço os edifícios Clermont, na Rua Jauaperi de 1973 [Figura 40] e o Protótipo de 1972, sendo o primeiro executado e o segundo não.

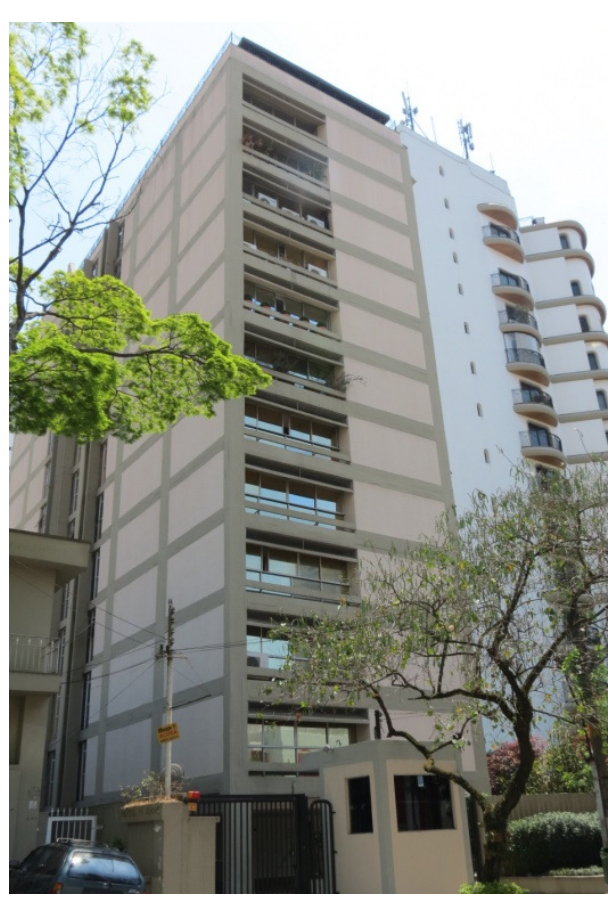

Figura 40 - Edifício Clermont, São Paulo - 1973 Foto - Priscylla Lima 
Para uma maior abordagem da tipologia Mendes da Rocha afirma que vale considerar, não só planta e corte como também o desenho da estrutura e a implantação do edifício. Além da função primária, as estruturas desenham, sobretudo, os espaços. As implantações, por sua vez, trabalham a relação do volume construído e o desenho do chão, redefinindo o lugar, as topografias e a relação com a cidade [Figura 41].

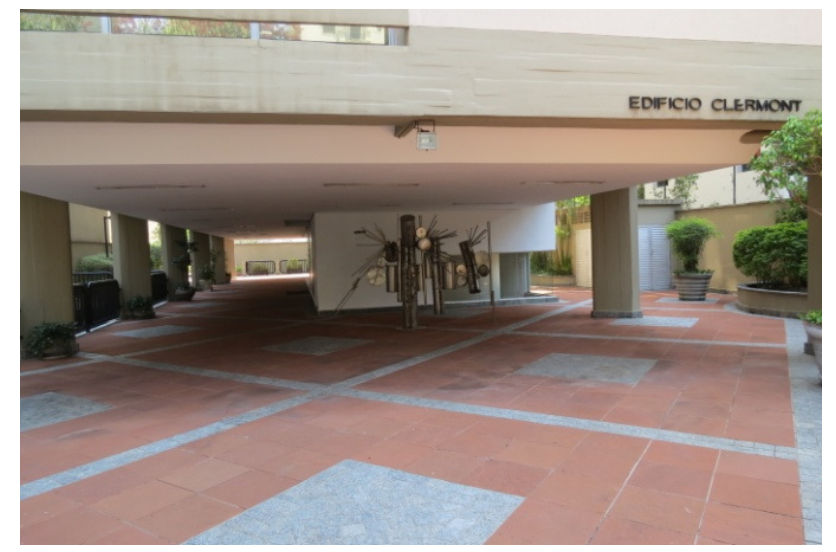

Figura 41 - Edifício Clermont, São Paulo - 1973 Foto - Priscylla Lima

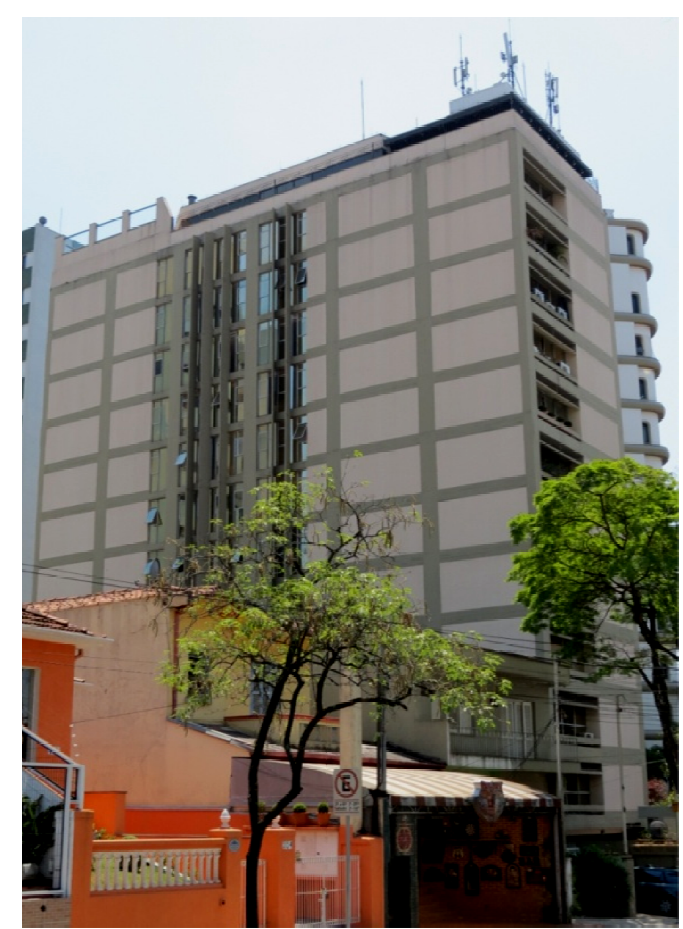

Figura 42 - Edifício Clermont, São Paulo - 1973 Foto - Priscylla Lima 
Iniciando pelas plantas e cortes, nota-se que a pesquisa tipológica do arquiteto caminha numa mesma direção. Tanto nos edifícios de um apartamento por andar de planta regular, como agrupando quatro apartamentos por andar, as plantas organizam-se em setores. Um setor corresponde ao amplo espaço articulador de convívio, que abrange toda uma dimensão do edifício, para o qual se abrem os espaços do segundo setor. Este outro, todo compartimentado, abriga serviços e quartos. O contraponto funcional e formal entre os setores é feito de forma em que um interfira no outro: o espaço de convivência relaciona-se com o espaço íntimo e de serviço; assim garante-se o diálogo entre os desenhos de um e de outro. A localização de acessos e aberturas acabam por configurar funções neste espaço total, sem perda da flexibilidade da planta, da fluidez do espaço e da sobreposição de funções.

A planta do edifício Clermont na Rua Jauaperi, Moema, apresenta rigorosa divisão longitudinal do programa. O arquiteto concentrou em uma das metades do andar toda a função do ambiente que representasse uma obstrução do espaço. A outra metade permanece livre. O grande salão, espaço total que se abre para três faces, é cuidadosamente desenhado de forma que, sem fragmentar, insinue as funções: receber, entrar, estar, comer. Isto ocorre a partir da introdução de uma única parede curva em determinada posição que desenha e organiza tudo. Este espaço estabelece relações para o interior, com os demais usos do apartamento, sendo ele próprio a circulação, e para o exterior, através de suas aberturas. Os elementos de abertura são muito presentes e definidores dos espaços totais, bem como a estrutura do edifício, que inevitavelmente comparece em sua totalidade, uma vez que o ambiente único atravessa o prédio. As vigas em sua conformação estrutural reduzem o pé direito pontualmente a $2,15 \mathrm{~m}$ e não pretendem ser neutras, fazem o desenho do teto. 
O outro setor do edifício Clermont contempla dormitórios com banhos, cozinha, serviços e circulação vertical e sua compartimentação ocorre de maneira independente da modulação da estrutura. Sobre a clareza da disposição do programa, sobrepõe-se uma complexidade de conformações para cada recinto, num contraponto lúdico entre o ato inicial de projeto e as possibilidades de variação de desenho que dele decorrem. Não há dois quartos iguais no apartamento.

Este projeto, como outros edifícios residenciais, apresenta indícios de trabalhar o corte. O quarto de empregada foi disposto a meio nível do restante do apartamento, com acesso externo independente pelo patamar da escada. Nas fachadas, elementos de concreto formam brises, abas, por vezes com função de bancadas, armários e dutos de ventilação, relevos que funcionam juntamente com vidros temperados sem caixilhos. 
PROJETO EDIFÍCIO

CLERMONT

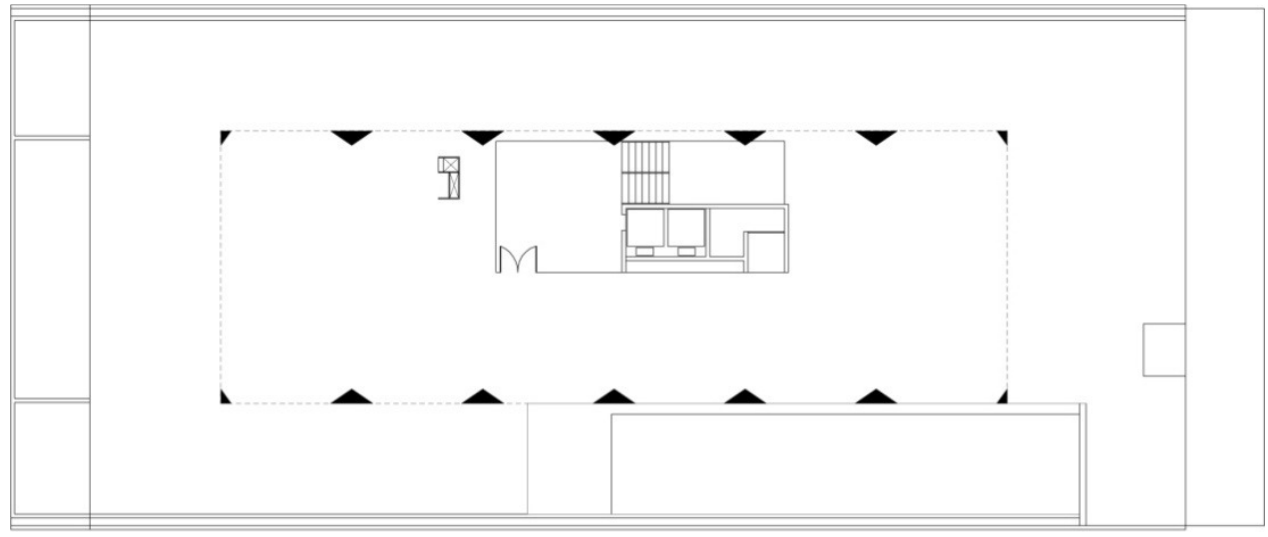

C 12

Planta Pavimento Terreo

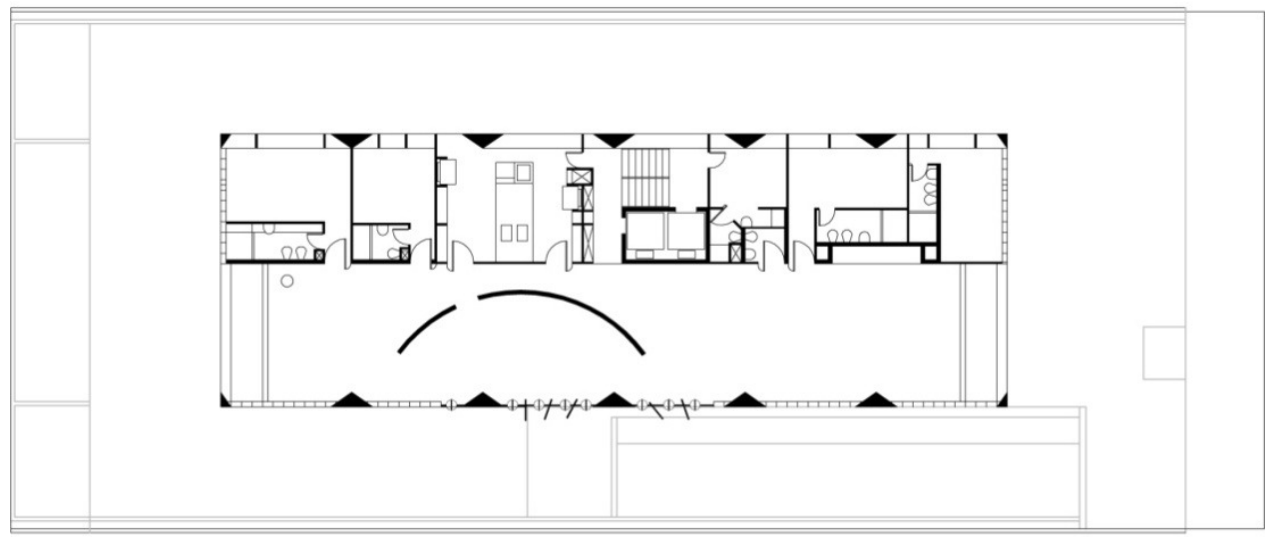

C $0.1^{2}$

Planta Pavimento Tipo 


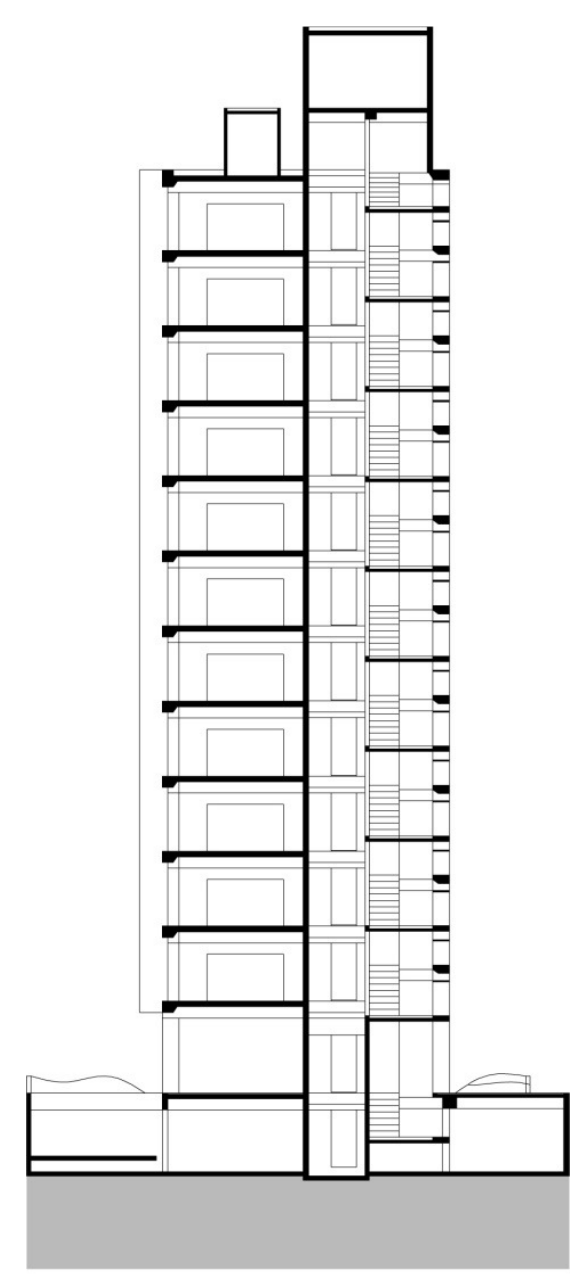

Corte Transversal 


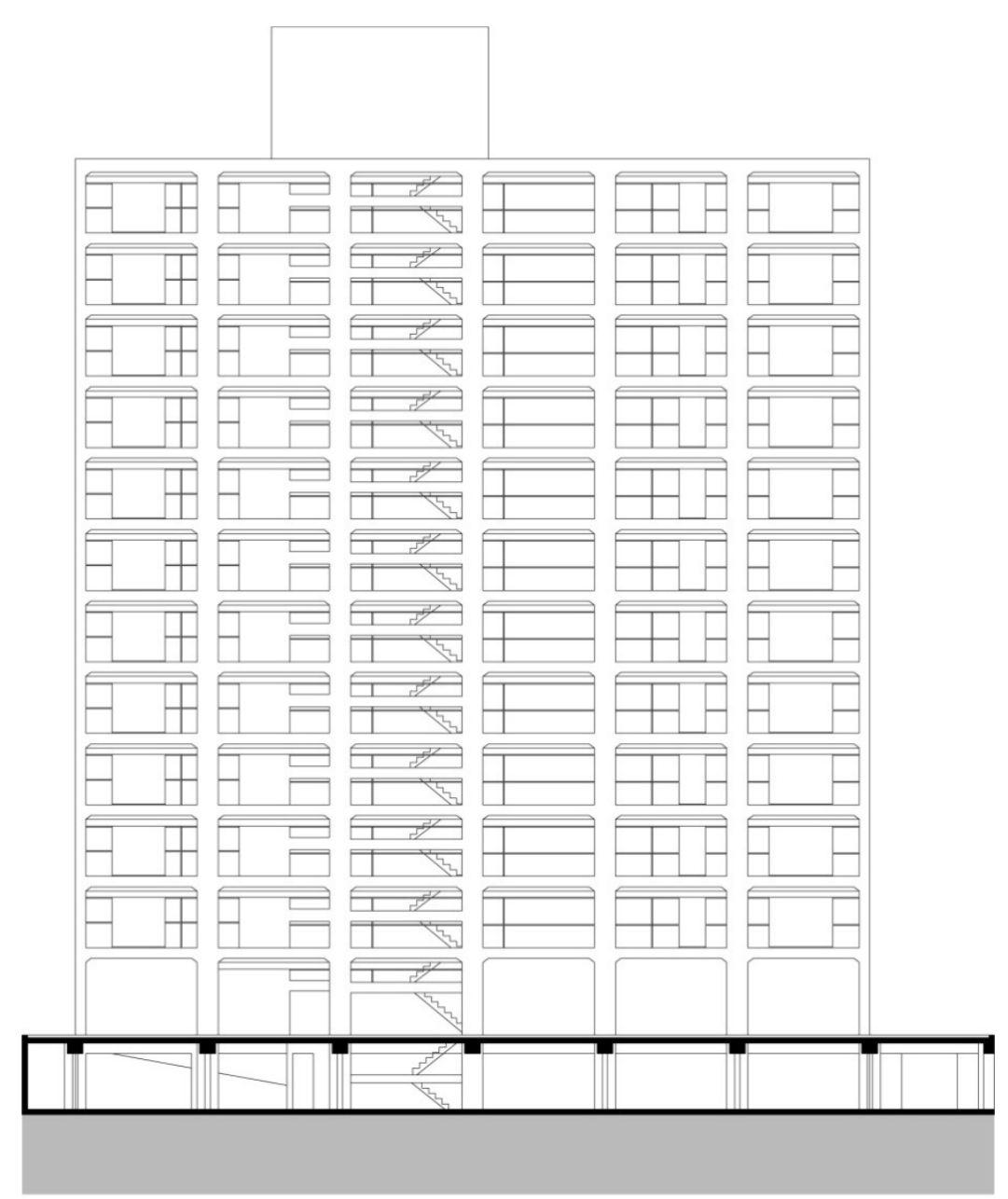

(

Elevação Longitudinal 
Em uma mesma pesquisa tipológica de planta, elaboração do corte, implantação do elemento edificado e sua relação com o chão construído, situa-se também o Protótipo. O edifício em série de quatro apartamentos por andar é uma composição de duas prumadas, com a circulação vertical unindo os blocos. Cada unidade é tratada com totalidade e surge como uma variação daquela mesma planta que torna a aparecer. O grande salão que ocupa toda a extensão do módulo é conformado por duas empenas de concreto estruturais e um pilar central. O espaço de convívio incorpora os quartos, mas de maneira flexível de acordo com o caráter do espaço total: os quartos são definidos por armários móveis, fixados embaixo e em cima e por portas pivotantes piso-teto. Com o recurso do elemento móvel, diferentes arranjos se tornam possíveis. Para todo este espaço é adotado na fachada um elemento único - o caixilho, brise, armário. No outro setor longitudinal do apartamento, que complementa o primeiro e com ele se relaciona, concentram-se as prumadas hidráulicas: banhos, cozinha, lavanderia e o quarto de empregada.

Para viabilizar este setor, o edifício é novamente trabalhado em corte. A ventilação da cozinha e banhos é resultado dos dutos horizontais compostos pelas próprias nervuras das lajes. As duas únicas vigas longitudinais são desenhadas abaixo das vigas transversais, permitindo que os dutos-nervura atravessem toda a espessura do edifício que, permeável, respira. Reforça-se aí, o caráter do engenho da construção.

Junto ao chão, o térreo é desdobrado em dois níveis. A partir do afastamento da laje superior em relação à rua, determinando um vazio, as cotas dos dois térreos mantém relação agradável com o 
passeio e a garagem aberta, não configurando um subsolo. Esta é apenas parcialmente coberta pelo térreo superior, salão de encontros aberto do edifício, que corresponde à laje recuada da rua e solta do fundo do lote, a ocupar uma parte transversal do terreno de divisa a divisa. A laje está para quem chega como um patamar isolado, suspenso. O acesso é feito pelo nível inferior, por elevador e escada, controlado por simples artifício de desenho.

A relação do volume construído com o desenho do chão é questão que o arquiteto formaliza com poética ao contrapor ao terreno desenhado a suspensão de um volume para "delimitar um lugar somente com a ação de cobrir um pedaço do chão ${ }^{28 \prime \prime}$. Outro caminho consiste em abrigar nos volumes suspensos apenas parcela do programa e imprimir a outra metade do edifício no terreno em um espaço de fácil percurso, que desenha nova geografia.

\footnotetext{
${ }^{28}$ PIÑON, Hélio. “Paulo Mendes da Rocha”. São Paulo. Romano Guerra, 2002 p. 10.
} 
PROJETO EDIFÍCIO

PROTÓTIPO

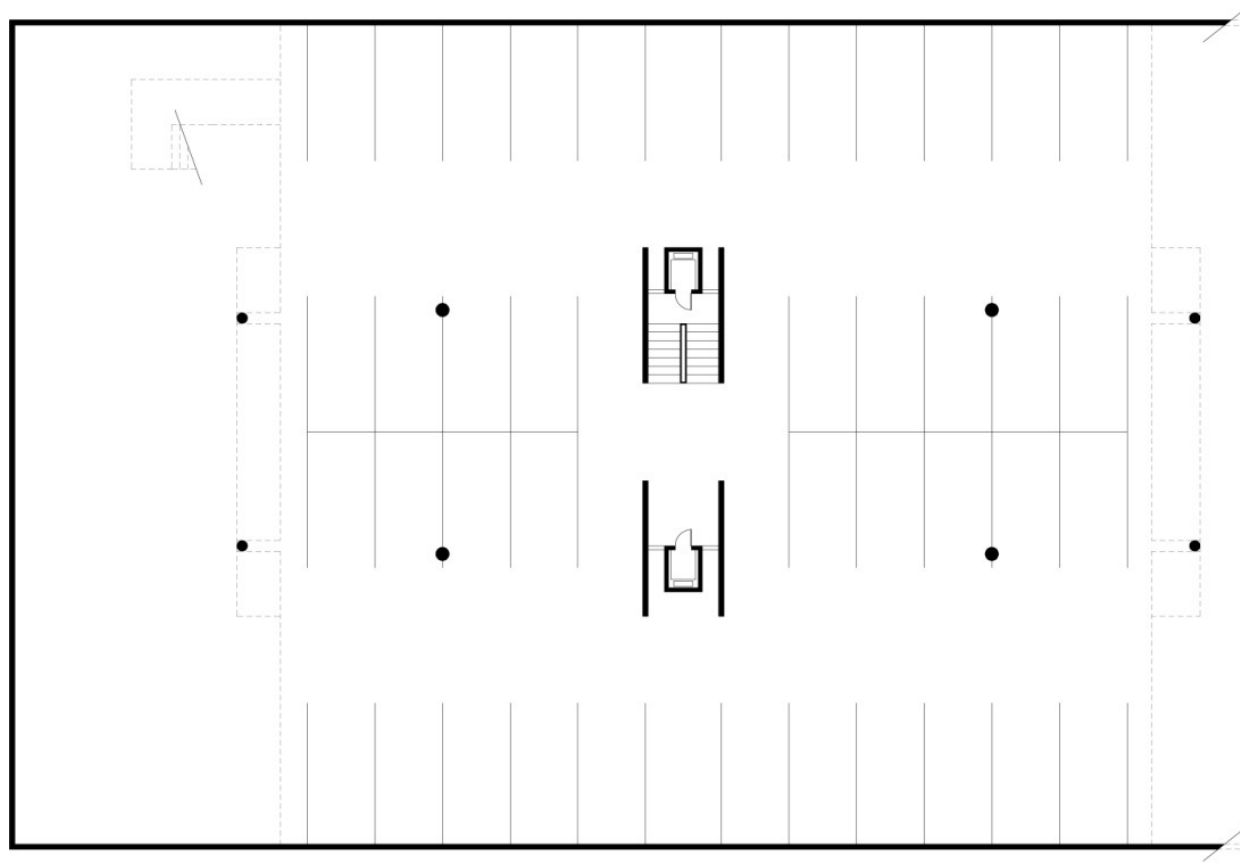

Planta Pavimento Terreo Inferior

88 


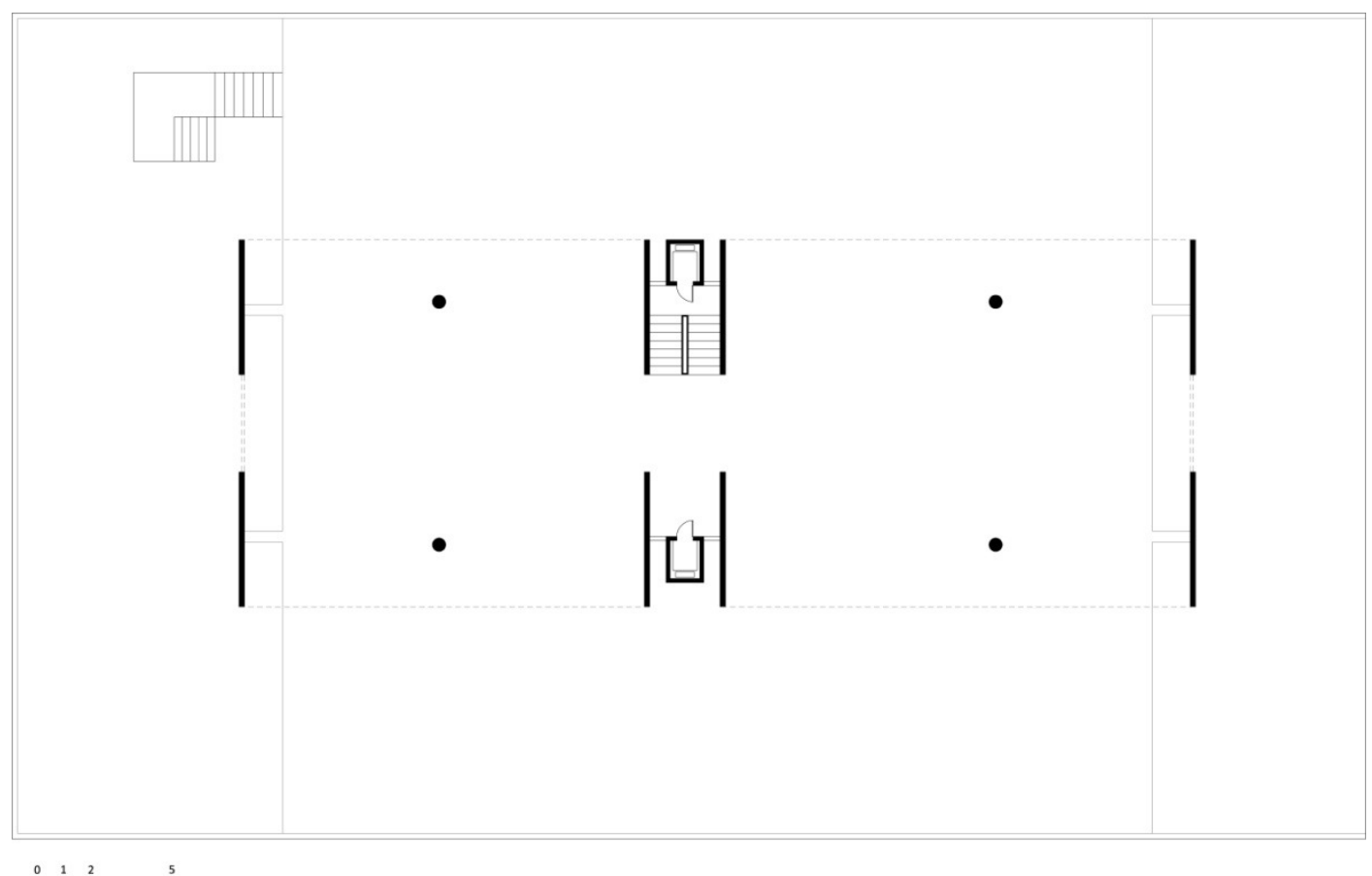

Planta Pavimento Terreo Elevado 


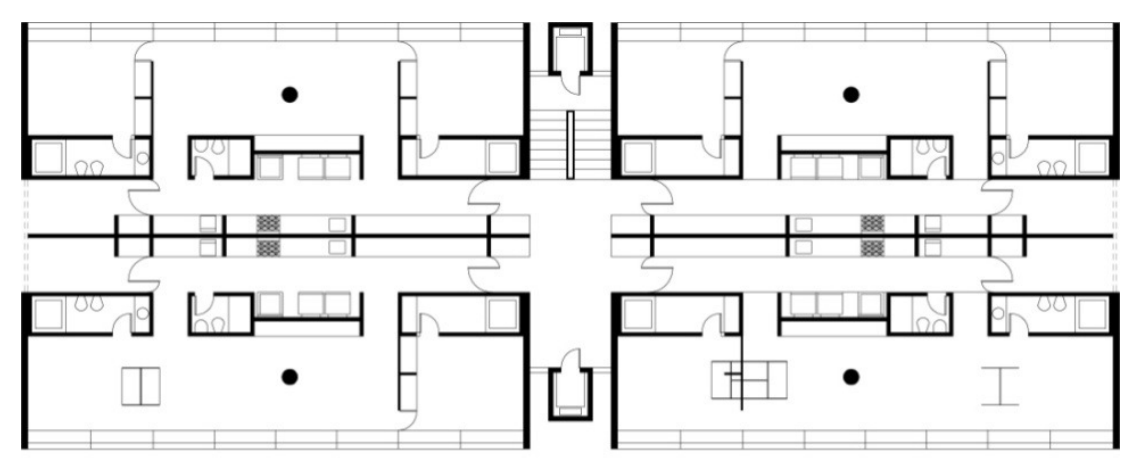

Planta Pavimento Tipo 


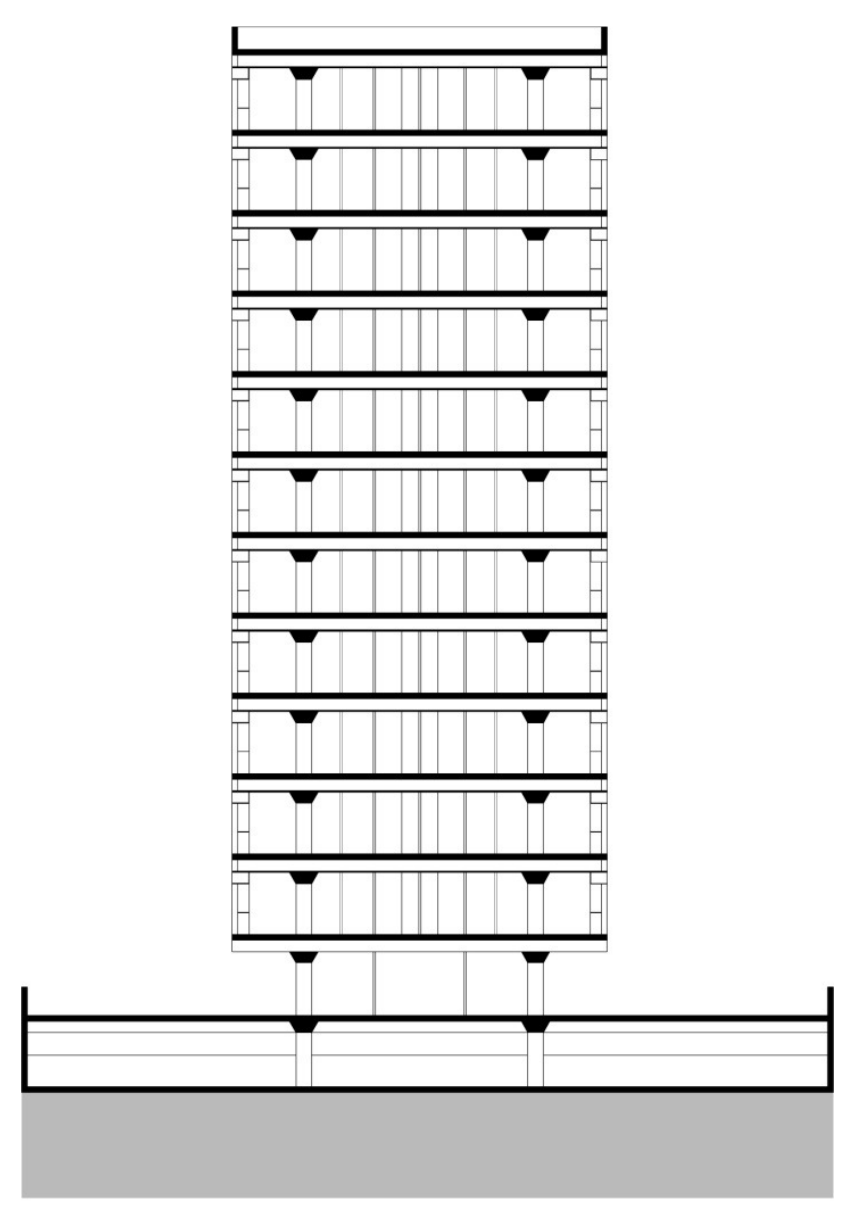

Corte Transversal 


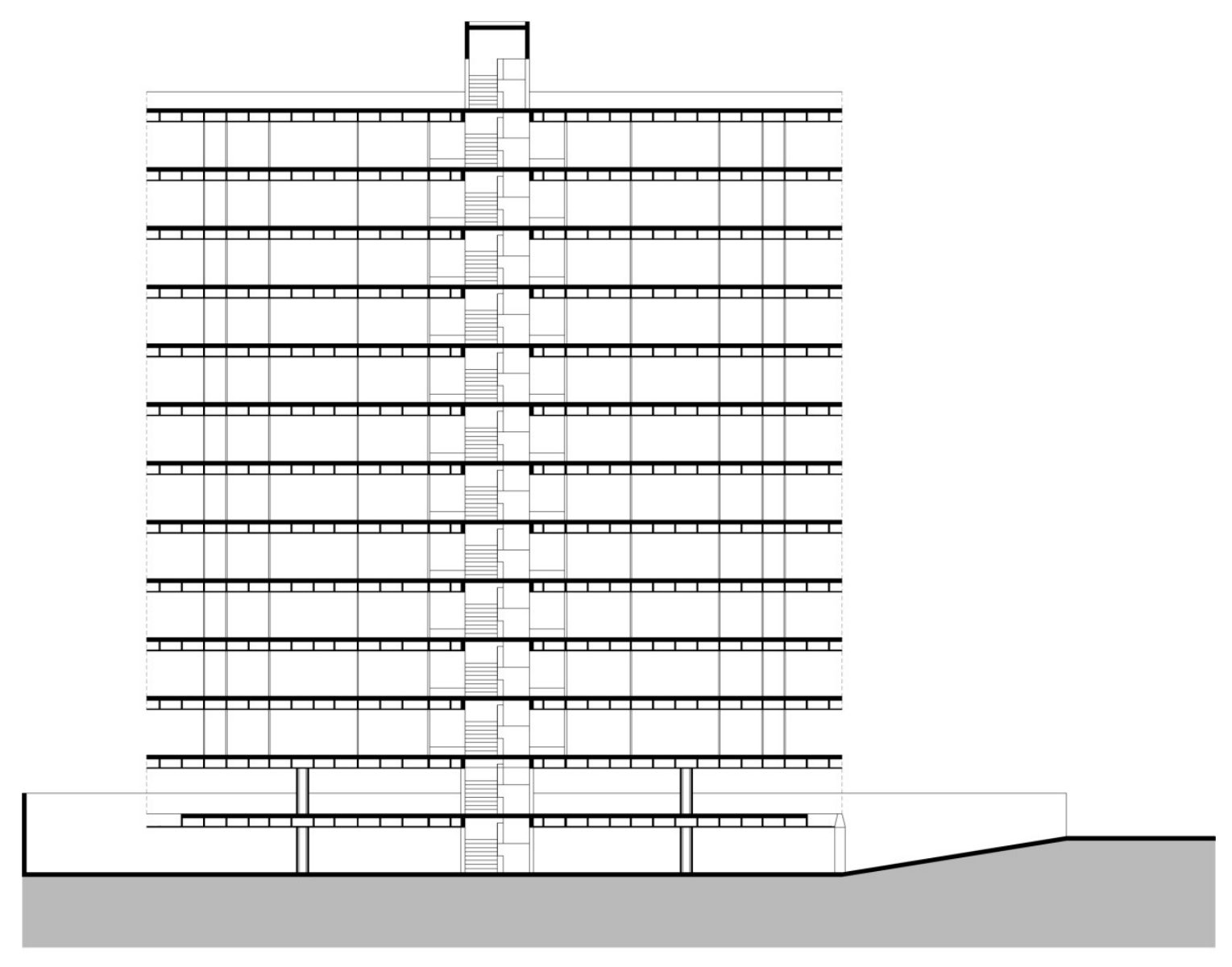

Corte Longitudinal 
3 SEGUNDO PERÍODO I 2000 - 2010 


\subsection{A PRODUÇÃO DE \\ APARTAMENTOS EM SÃO \\ PAULO NA PRIMEIRA \\ DÉCADA DO SÉCULO 21}

O mercado imobiliário paulistano através das diversas formas de atuação de seus agentes tornou-se, ao longo do século 20, uma referência nacional. Segundo VILLA, desde a década de 40, os apartamentos de dois e três dormitórios começaram a constituir uma categoria de apartamentos médios que se apresentou consolidada nas últimas décadas do século 20. As áreas foram se reduzindo e até 2005, basicamente situavam-se entre $55 \mathrm{~m}^{2}$ e $70 \mathrm{~m}^{2}$ [ver tabela 01]. Esta fórmula espacial tornou-se tão comum que, principalmente a partir da segunda metade da década de 90, suas peças publicitárias suprimiam a planta. Dispensava-se demonstrar uma organização espacial que todos já tinham em mente. Ao observarmos a distribuição interna destes apartamentos, notamos que a produção imobiliária não se interessou em oferecer, especialmente neste caso, novas organizações espaciais que respondessem às novas necessidades dos modos de vida contemporâneos. As soluções continuam convencionais e totalmente estanques, na qual a tripartição em zonas íntima, social e de serviços é ainda a regra. Apresentando um desenho que se repetia também nas unidades de um dormitório, a fórmula adotada é a de estruturar o projeto em três núcleos articulados sempre de maneira semelhante ${ }^{29}$.

${ }^{29}$ Dados extraídos da tese de doutorado VILLA, Simone Barbosa - "Morar em apartamentos: a produção dos espaços privados e semi-privados
nos edifícios ofertados pelo mercado imobiliário no século XXI em São Paulo e seus impactos na cidade de Ribeirão Preto. Critérios para Avaliação Pós-Ocupação". FAU-USP. São Paulo, 2008. 
TABELA 01

EVOLUÇÃo DAS ÁREAS ÚTEIS MÉDIAS DOS APARTAMENTOS POR NÚMERO DE DORMITÓRIOS LANÇADAS NO MUNICÍPIO DE SÃO PAULO (1985-2004)

\begin{tabular}{|c|c|c|c|c|}
\hline \multirow[b]{2}{*}{ PERÍODO } & \multicolumn{4}{|c|}{ ÁREAS ÚTEIS MÉDIAS ( $\mathrm{m}^{2}$ ) } \\
\hline & 01 dorm. & 02 dorm. & 03 dorm. & 04 dorm. \\
\hline 1985 & 40,77 & 64,87 & 114,03 & 191,34 \\
\hline 1987 & 40,28 & 59,24 & 97,69 & 251,13 \\
\hline 1989 & 38,08 & 60,11 & 98,72 & 218,09 \\
\hline 1991 & 40,23 & 57,51 & 98,51 & 168,04 \\
\hline 1993 & 39,42 & 55,65 & 82,50 & 175,49 \\
\hline 1995 & 40,14 & 57,04 & 83,37 & 158,96 \\
\hline 1997 & 30,87 & 54,63 & 74,93 & 205,53 \\
\hline 1999 & 31,21 & 54,34 & 79,17 & 193,13 \\
\hline 2000 & 31,94 & 53,19 & 80,52 & 180,83 \\
\hline 2002 & 39,99 & 55,63 & 84,85 & 174,25 \\
\hline 2004 & 52,44 & 59,65 & 87,29 & 184,52 \\
\hline
\end{tabular}


No início da primeira década do século 21, o quadro geral dos apartamentos construídos na cidade de São Paulo pouco se altera. Em meio a uma diversidade cada vez maior de perfis de grupos domésticos, e das alterações cada vez mais múltiplas de seus modos de vida, os idealizadores de edifícios de apartamentos, associados a incorporadores e vendedores, parecem responder a essas demandas de uma maneira pouco convincente. Como em outras épocas, o desejo e as necessidades dos moradores são, de maneira geral, atendidos minimamente sob a alegação de que se chegou a resultados projetuais economicamente viáveis.

Cada vez mais, notamos a valorização da esfera coletiva dos edifícios, principalmente quando falamos de espaços produzidos para as classes média e alta da sociedade. Isto se deve principalmente, ao fato de que a área da unidade está, de maneira geral, cada vez menor, e grande parte das atividades deixa de ser realizada dentro dela. Além dos espaços de lazer tradicionais como piscinas, playgrounds e áreas verdes [Figuras 43 e 44], vários empreendimentos começaram a oferecer espaços específicos para outras atividades anteriormente realizadas nos apartamentos de áreas maiores. Entre eles estão o lounge - descrito em alguns panfletos como um espaço para receber pessoas e o espaço gourmet local dotado de cozinha, sala de jantar e equipamentos destinados a reuniões gastronômicas dos moradores e seus convidados. 


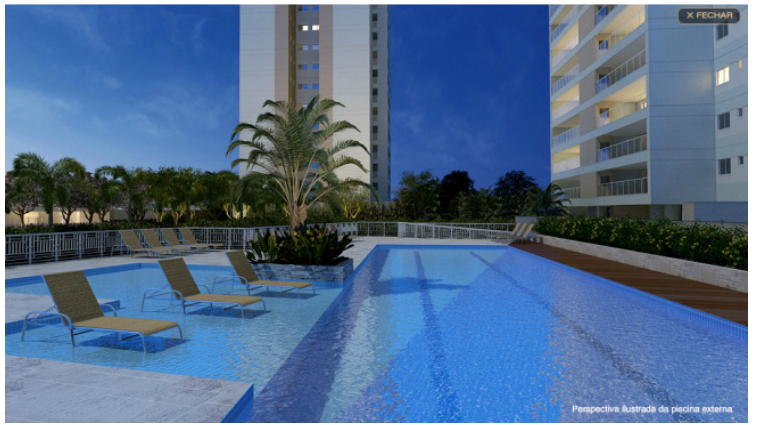

Figura 43- Edifício The Parker, Aclimação, Camargo Corrêa, 2011

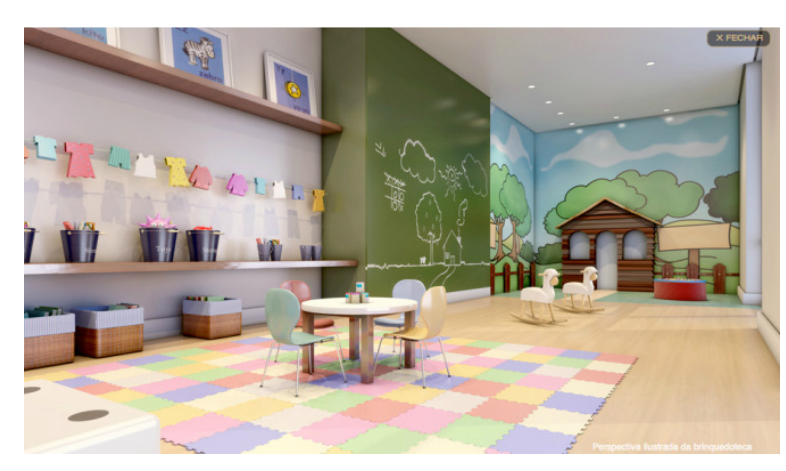

Figura 44- Edifício The Parker, Aclimação, Camargo Corrêa, 2011.

O hall de entrada tem freqüentemente pé-direito duplo e refinados materiais de acabamento, passando a ser chamado de lobby. Nota-se também nestes empreendimentos, a presença de cyber café, fitness center, spa, entre outros, ressaltando-se que a maioria dos nomes designando esses espaços estão na língua inglesa. Alguns destes equipamentos, longe de se constituírem como novidades, são versões maquiadas dos antigos salões de festas, academias de ginásticas, hall de entrada e salas de repouso presentes nos edifícios das décadas de 80 e 90.

Os novos equipamentos sugerem o suprimento de algumas demandas típicas da metrópole contemporânea. Uma delas pode estar associada à importância que o uso do tempo passa a ter na vida das pessoas, daí a crescente oferta de empreendimentos dotados de serviços típicos de hotelaria, como o long stay, um tipo de flat destinado a pequenos grupos familiares; normalmente composto por dois ou três dormitórios. No caso dos apartamentos convencionais, também tem sido notado o aumento da quantidade de serviços oferecidos pelo condomínio, desde serviços domésticos, como 
lavar, passar e cozinhar, até atividades externas como pequenas compras e pagamentos. Há casos em que esses serviços se estendem à vigilância dos filhos, à disposição de motorista, personal trainer, etc..

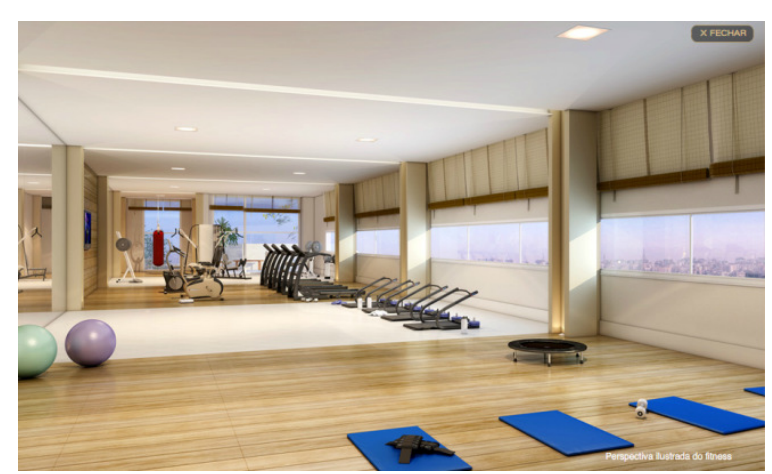

Figura 45 - Edifício The Parker, Aclimação, Camargo Corrêa, 2011. Perspectiva llustrativa do Fitness Center. (www.theparker.com.br)

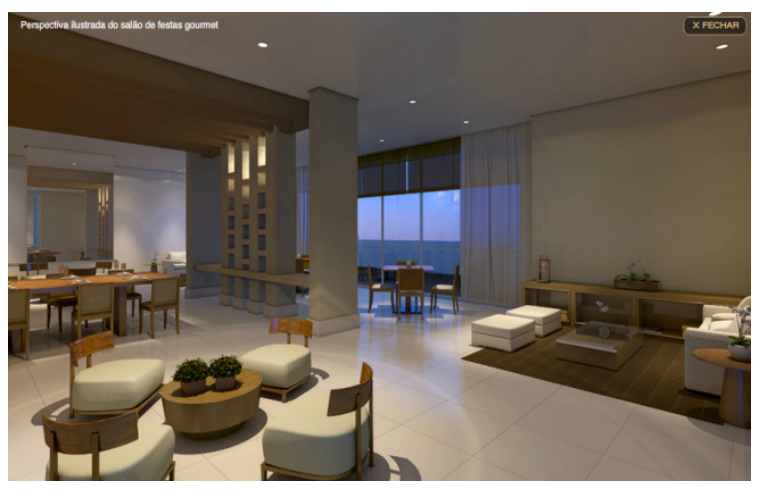

Figura 47 - Edifício The Parker, Aclimação, Camargo Corrêa, 2011. Perspectiva llustrativa do Salão Gourmet. (www.theparker.com.br)

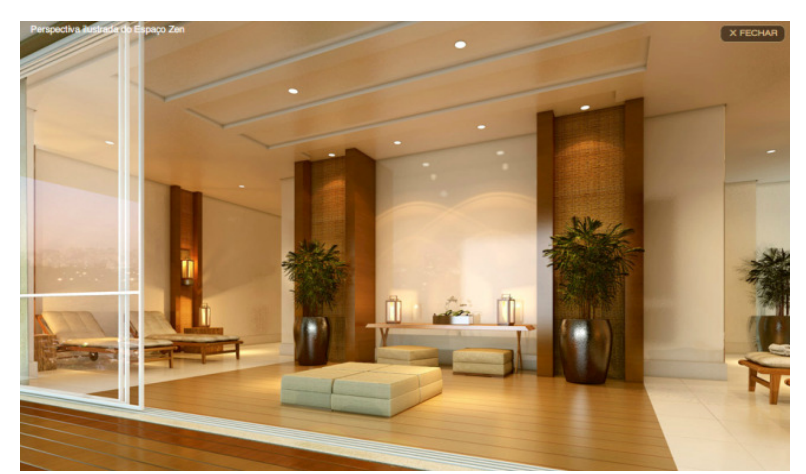

Figura 46 - Edifício The Parker, Aclimação, Camargo Corrêa, 2011. Perspectiva llustrativa do Espaço Zen. (www.theparker.com.br)

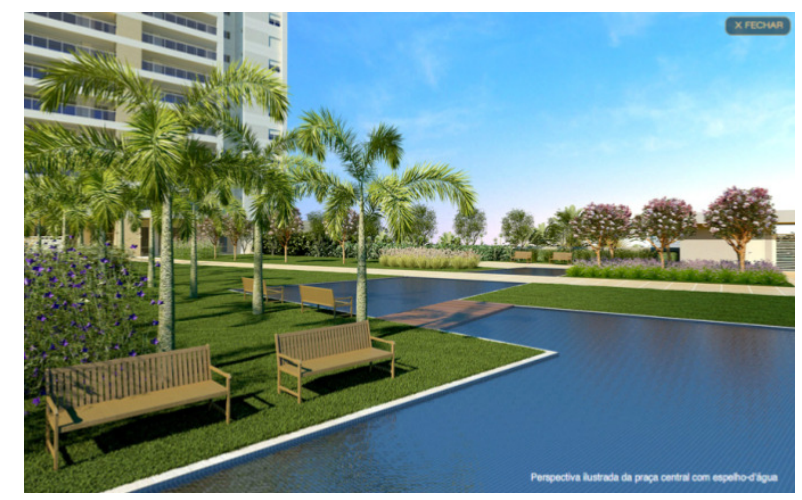

Figura 48 - Edifício The Parker, Aclimação, Camargo Corrêa, 2011 Perspectiva llustrativa da Praça das Águas. (www.theparker.com.br) 
Algumas destas tendências podem ser confirmadas por SANTOS e ORNSTEIN ${ }^{30}$, na pesquisa realizada com lançamentos do ano de 2002, na qual foi feita uma análise minuciosa dos empreendimentos residenciais verticalizados. Também foi verificada a influência de cada um dos agentes do mercado imobiliário no processo de projeto, construção e desempenho no decorrer do uso de tais empreendimentos. As principais tendências indicadas pelas autoras foram:

1. Diminuição das áreas privativas dos apartamentos;

2. Aumento das áreas comuns, exceto nos empreendimentos mais simples;

3. Surgimento do home office e home theater nos ambientes dos apartamentos de classe média alta, destacando-se nas áreas comuns cyberspace, fitness center e espaço gourmet;

4. Apresentação de serviços hoteleiros em alguns edifícios.

Outra demanda metropolitana pode estar associada à idéia de stress provocado pela vida cotidiana, veiculada por meios de comunicação. Ela traz subjetivamente a mensagem de que todos deveriam combater o problema destinando alguns momentos do dia a atividades prazerosas e relaxantes.

A resposta dos idealizadores à esta solicitação tem sido notada na forma de inserções de espaços destinados a massagens, terapias alternativas, atividades de culto ao corpo em áreas coletivas do edifício, geralmente dotadas de jardins planejados com o uso da técnica do feng shui e espelhos d'água.

30 Dados extraídos de SANTOS, M. B. P.; ORNSTEIN, S. W. São Paulo: lançamentos 2002 e perspectivas futuras, a qualidade do projeto habitacional sob a ótica dos principais agentes envolvidos na produção do empreendimento. . Brasil - Belo Horizonte, MG. 2003. 
O requinte e a quantidade de tais serviços coletivos se relacionam, diretamente, como sempre, ao poder aquisitivo do morador.

Em relação aos espaços internos das unidades, observamos que grande parte dos edifícios de apartamentos, independentemente da classe social a que se destina, e apesar de todas as mudanças de estilos de vida citadas anteriormente, apresenta uma fórmula espacial recorrente. A resposta do mercado tem sido na maioria das vezes, uma associação entre o modelo habitacional burguês oitocentista e aspectos do modelo funcionalista veiculado pela arquitetura modernista.

Destacam-se, neste período, alguns lançamentos de apartamentos de um dormitório dentro do quadro geral da cidade de São Paulo, por apresentarem, em geral, um aumento significativo de suas áreas úteis, acompanhado de uma supervalorização de suas áreas coletivas, tratadas como extensões necessárias do apartamento. Frequentemente destinado a uma parcela da sociedade que não se encaixa no formato de família nuclear - casais sem filhos recém-casados, solteiros, divorciados, viúvos ou viúvas -, tais apartamentos tendem a abrigar moradores das faixas mais altas de renda.

Os apartamentos de 04 ou mais dormitórios também tiveram suas áreas úteis aumentadas. Em 1990, a área útil média dos lançamentos de 04 dormitórios era de $209,53 \mathrm{~m}^{2}$, que passou para $285,91 \mathrm{~m}^{2}$ no mês de julho de 2002 [ver tabela 02]. Esse aumento pode estar associado ao fato de que a grande maioria destes empreendimentos, principalmente aqueles destinados aos mais abonados, dotou todos ou quase todos os seus dormitórios de banheiros. Esta atitude demonstra outra tendência clara nos últimos anos, o incremento da privacidade dentro do espaço doméstico, principalmente burguês. Cada indivíduo 
possui na maioria das vezes, um espaço de isolamento dentro do apartamento. Isto se estende também ao espaço do casal, agora dotado de banheiros e closets separados. No interior destes grandes apartamentos são criados domínios individuais, dotados de equipamentos também de uso individual como os computadores, televisores, leitores de vídeo, tablets, telefone, que propiciam conexões com mundo externo -, e os equipamentos básicos para a higienização, realização de necessidades fisiológicas e os cuidados com o próprio corpo. As atividades de relaxamento e prazer também são evidenciadas pela presença da banheira em algumas suítes, e sempre na suíte do casal.

Tal aumento da área dos grandes apartamentos se deve também ao aumento no número de outros cômodos. Por um lado, cômodos como a louçaria, a prataria e a chapelaria voltaram a aparecer após tantos anos de banimento, num intuito claro de dotar o apartamento com a sofisticação dos palacetes do começo do século, ou, pelo menos, com sua evocação. Por outro lado, certa recusa das classes mais ricas em usar áreas e serviços coletivos de seus prédios, fez com que alguns serviços fossem incorporados ao apartamento, como é o caso das churrasqueiras, escritório, home theater, além dos vários livings e varandas que tentam reproduzir as áreas ajardinadas e de convívio do térreo. Porém, os espaços coletivos continuam a oferecer inúmeros serviços de lazer e culto ao corpo, atividades freqüentemente realizadas em grupo [Figura 49]. Aumentam também, o número de vagas nas garagens, alguns empreendimentos chegando a oferecer 06 ou mais vagas por apartamento. 


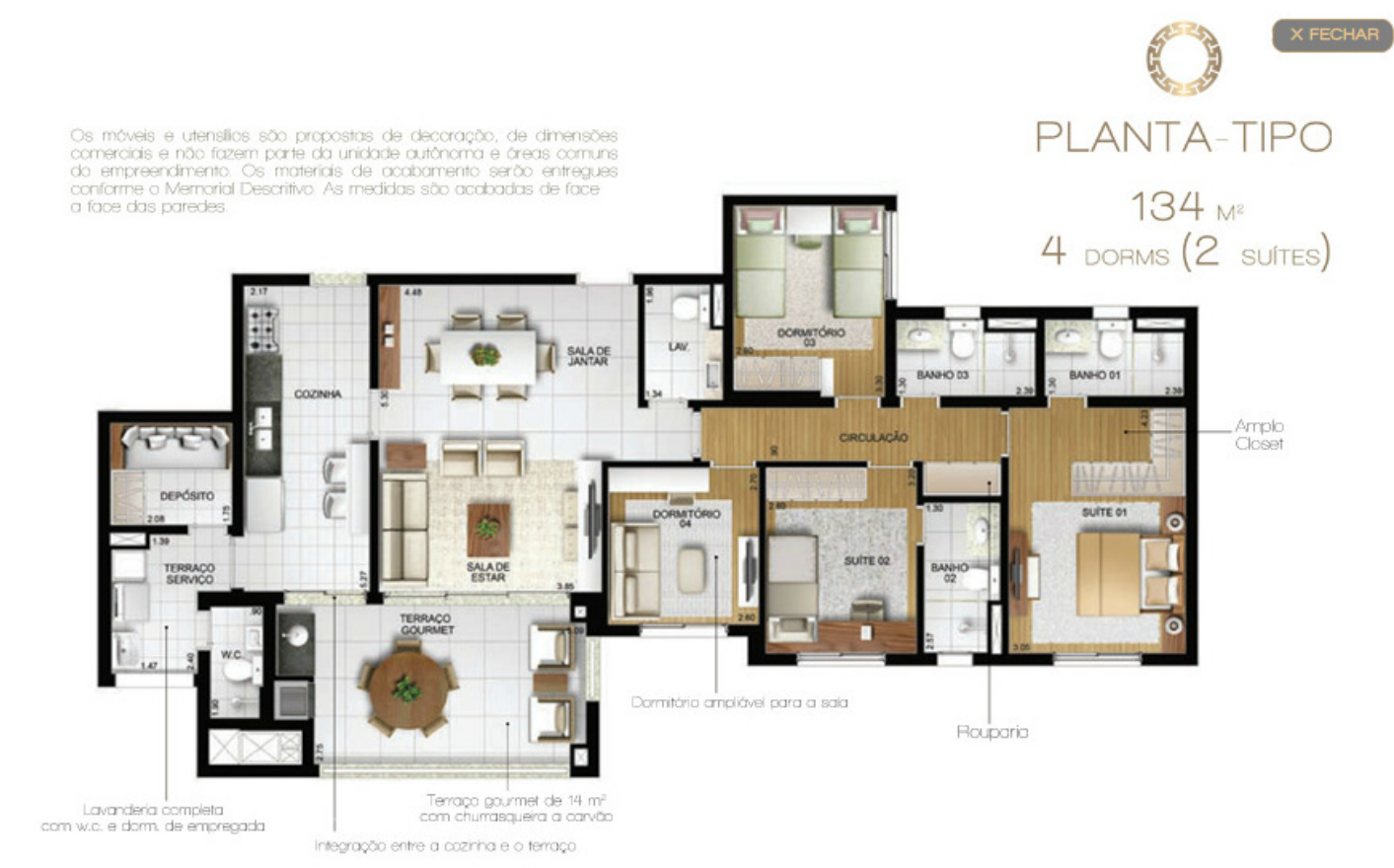

Figura 49 - Edifício The Parker, SP, 134 m², tipologia "quatro dormitórios compacto". 
TABELA 02 - EVOLUÇÃO DO NÚMERO DE UNIDADES RESIDENCIAIS (APARTAMENTOS), CLASSIFICADOS POR NÚMERO DE DORMITÓRIOS LANÇADAS NO MUNICÍPIO DE SÃO PAULO.

\begin{tabular}{|c|c|c|c|c|}
\hline Ano & 1 dorm. (\%) & 2 dorm. (\%) & 3 dorm. (\%) & 4 ou mais dorm. (\%) \\
\hline 1990 & 10,41 & 58,03 & 26,96 & 5,59 \\
\hline 1991 & 13,99 & 62,08 & 18,55 & 5,35 \\
\hline 1992 & 8,49 & 59,59 & 26,17 & 5,73 \\
\hline 1993 & 3,81 & 47,12 & 39,06 & 10,00 \\
\hline 1994 & 5,83 & 41,08 & 44,21 & 8,85 \\
\hline 1995 & 6,30 & 39,26 & 39,87 & 14,53 \\
\hline 1996 & 9,63 & 36,41 & 48,81 & 5,13 \\
\hline 1997 & 14,63 & 37,08 & 46,03 & 2,25 \\
\hline 1998 & 25,85 & 29,34 & 32,96 & 11,83 \\
\hline 1999 & 19,71 & 46,47 & 27,13 & 6,68 \\
\hline 2000 & 17,19 & 45,35 & 27,62 & 9,82 \\
\hline 2001 & 17,45 & 41,16 & 31,15 & 11,60 \\
\hline 2002 & 11,08 & 39,82 & 29,11 & 19,98 \\
\hline 2003 & 12,74 & 35,70 & 33,29 & 18,26 \\
\hline 2004 & 5,78 & 39,17 & 31,49 & 23,54 \\
\hline
\end{tabular}




\begin{tabular}{|r|r|r|r|r|}
\hline $\mathbf{2 0 0 5}$ & 7,41 & 29,52 & 34,95 & 28,09 \\
\hline $\mathbf{2 0 0 6}$ & 3,70 & 28,60 & 30,60 & 37,10 \\
\hline $\mathbf{2 0 0 7}$ & 1,40 & 32,40 & 32,10 & 34,10 \\
\hline $\mathbf{2 0 0 8}$ & 4,20 & 33,70 & 38,40 & 14,80 \\
\hline $\mathbf{2 0 0 9}$ & 6,10 & 45,60 & 33,50 & 8,30 \\
\hline $\mathbf{2 0 1 0}$ & 11,40 & 48,70 & 31,60 & \\
\hline
\end{tabular}

A partir do ano 2000, notamos certo incremento no número de lançamento de 04 ou mais dormitórios de $9,82 \%$ em 2000 para 28,09\% em 2005. Grande parte destes dados se refere a uma nova fatia do mercado considerada atualmente como a preferida dos lançamentos imobiliários do município de São Paulo: o "quatro dormitórios compacto"31. Variando sua área útil de $105 \mathrm{~m}^{2}$ até $180 \mathrm{~m}^{2}$, esta tipologia de apartamento oferece à classe média uma opção ilusória, na grande maioria dos casos, de maiores áreas, já que os preços ofertados são bastante semelhantes com os de apartamentos de três dormitórios. Aumentou-se a área em apenas alguns metros, entretanto somaram-se pelo menos mais dois cômodos: um dormitório com suíte. É possível encontrarmos no mercado imobiliário paulistano apartamentos de quatro dormitórios com área útil de $105 \mathrm{~m}^{2}$ com até duas suítes.

${ }^{31}$ Dados extraídos da tese de doutorado VILLA, Simone Barbosa - "Morar em apartamentos: a produção dos espaços privados e semi-privados nos edifícios ofertados pelo mercado imobiliário no século XXI em São Paulo e seus impactos na cidade de Ribeirão Preto. Critérios para Avaliação Pós-Ocupação". FAU-USP. São Paulo, 2008. 
A grande procura por esta tipologia pode estar associada a vários fatores. Inicialmente o morador com o acréscimo de mais um cômodo em seu apartamento terá a oportunidade de mais um dormitório, ou mais uma sala, seja a sala de TV, ou o escritório. Grande parte destes empreendimentos é lançada em bairros que apresentam um custo de fração do terreno mais barato, como Mooca e Lapa, o que diretamente influi na diminuição do preço final do imóvel, igualando-se a valores expressos em apartamento de três dormitórios em bairros mais nobres.

Exatamente na direção esperada, os apartamentos de dois e três dormitórios continuaram a perder área útil até os anos 2000, principalmente os destinados às classes de renda média e média-baixa. Segundo dados da Embraesp, a média da área útil dos apartamentos de dois e três dormitórios, no ano de 1990 , era de respectivamente 59,57 e $86,54 \mathrm{~m}^{2}$. Já no ano de 2002 , a área útil média dos mesmos apartamentos foi de, respectivamente, 49,90 e 77,23m² [ver tabela 03]. Até o ano de 2005 esta tendência se manteve para os apartamentos de dois dormitórios, entretanto nos de três dormitórios notamos certo aumento de áreas úteis. Esta configuração de dois e três dormitórios continua exatamente igual à de décadas passadas, sem muitas variações. Alguns empreendimentos do mercado continuam a oferecer as chamadas opções de plantas, com variações muitas vezes superficiais, onde se elimina um quarto para ter uma área de sala maior. Entretanto, uma tendência que observamos nestes apartamentos e também em edifícios destinados às classes mais abonadas é a de se dotar um edifício de sistema estrutural capaz de abrigar plantas livres e, a partir daí, oferecer possibilidades de agenciamentos com um a três dormitórios. As variações e as possibilidades são inúmeras, porém a 
lógica destes empreendimentos segue o padrão das antigas "opções de plantas": construída a configuração eleita, esta não se altera mais, a não ser que uma reforma seja realizada no apartamento.

TABELA 03 - EVOLUÇÃO DAS ÁREAS MÉDIAS DE UNIDADES RESIDENCIAIS (APARTAMENTOS), CLASSIFICADAS POR NÚMERO DE DORMITÓRIOS LANÇADAS NO MUNICÍPIO DE SÃO PAULO

\begin{tabular}{|c|c|c|c|c|c|c|c|c|}
\hline \multirow[t]{2}{*}{ Perríodo } & \multicolumn{2}{|c|}{01 dorm. } & \multicolumn{2}{|c|}{02 dorm. } & \multicolumn{2}{|c|}{03 dorm. } & \multicolumn{2}{|r|}{04 dorm. } \\
\hline & Útil & Total & Útil & Total & Útil & Total & Útil & Total \\
\hline 1990 & 37,76 & 82,17 & 59,57 & 112,04 & 86,54 & 160,75 & 209,53 & 399,30 \\
\hline 1991 & 40,23 & 94,11 & 57,51 & 110,18 & 98,51 & 185,38 & 168,04 & 331,18 \\
\hline 1992 & 40,72 & 80,59 & 57,96 & 105,89 & 84,08 & 152,80 & 195,90 & 384,32 \\
\hline 1993 & 39,42 & 79,51 & 55,65 & 101,25 & 82,50 & 161,48 & 175,49 & 334,33 \\
\hline 1994 & 39,52 & 80,59 & 56,19 & 101,55 & 82,35 & 159,46 & 150,20 & 288,01 \\
\hline 1995 & 40,14 & 85,37 & 57,04 & 106,07 & 83,37 & 162,62 & 158,96 & 306,31 \\
\hline 1996 & 31,00 & 71,16 & 56,12 & 102,46 & 75,27 & 132,17 & 213,38 & 396,02 \\
\hline 1997 & 30,87 & 69,23 & 54,63 & 91,54 & 74,93 & 134,60 & 205,53 & 389,32 \\
\hline 1998 & 33,81 & 75,44 & 54,46 & 106,88 & 80,10 & 151,67 & 174,41 & 403,92 \\
\hline 1999 & 31,21 & 69,65 & 54,34 & 98,84 & 79,17 & 146,74 & 193,13 & 364,02 \\
\hline 2000 & 33,82 & 72,39 & 52,19 & 96,53 & 79,41 & 148,61 & 181,18 & 341,19 \\
\hline 2001 & 30,70 & 64,19 & 51,22 & 93,34 & 80,97 & 151,51 & 188,75 & 355,64 \\
\hline 2002 & 39,99 & 79,36 & 55,63 & 100,23 & 84,85 & 160,11 & 174,25 & 331,61 \\
\hline
\end{tabular}




\begin{tabular}{|r|r|r|r|r|r|r|r|r|}
\hline $\mathbf{2 0 0 3}$ & 33,00 & 69,11 & 57,98 & 106,03 & 88,37 & 163,82 & 166,50 & 315,45 \\
\hline $\mathbf{2 0 0 4}$ & 52,44 & 101,17 & 59,65 & 108,45 & 87,29 & 162,57 & 184,52 & 348,12 \\
\hline $\mathbf{2 0 0 5}$ & 41,92 & 78,37 & 54,42 & 97,59 & 87,73 & 159,61 & 178,21 & 333,77 \\
\hline \multicolumn{7}{|c|}{ Fonte: Embraesp, relatórios anuais, 1990-2005. } \\
\hline
\end{tabular}

Segundo dados da Embraesp, de 1997 a 2001 o mercado imobiliário lançou um número maior de unidades de um dormitório em relação ao período de 1987 a 1997, representando, por exemplo, no ano de $2001,17,45 \%$ do total de lançamento na cidade de São Paulo. Entretanto notamos que a partir de 2002 estes números caem drasticamente até chegar em 2004 com 5,78\% do total de lançamentos e 2005 com 7,41\%. Já as unidades de dois e três dormitórios sofreram menor enfoque no mercado de lançamentos, alcançando respectivamente 41,16\% e 31,15\% no ano de 2001 e durante os anos de 2002 a 2005 perderam postos, principalmente os de dois dormitórios - representavam 29,52\% dos lançamentos no ano de 2005 [ver tabela 04]. Isto mostra e enfatiza o redirecionamento do mercado imobiliário paulistano para a produção de apartamentos de quatro dormitórios compacto. 
Embora a demanda por imóveis menores tenha aumentado - fruto da redução do número de membros da família nuclear, o mercado, por motivo socioeconômico, vem reduzindo a produção destas unidades.

A grande maioria das pequenas famílias é da classe média ou baixa renda que encontram várias dificuldades para aquisição da casa própria, notadamente dos financiamentos. Por este e outros motivos, as construtoras preferiram se concentrar na produção de unidades para as classes mais altas,

que normalmente compram imóveis de quatro dormitórios ou mais. Segundo Luis Paulo Pompéia ${ }^{32}$ é um mercado certo e de venda mais rápida, ao contrário do que ocorre com imóveis para as classes média e popular.

De maneira geral, as propagandas de lançamentos dos edifícios de apartamentos produzidos em São Paulo nos primeiros anos do século 21 enfatizam, principalmente, o bem-estar e uma maneira de viver considerada saudável, prática e moderna. Tais referências não ultrapassam o folheto de divulgação, já que as supostas novidades oferecidas pelos empreendimentos são versões maquiadas de algumas atividades antigas e tradicionais, e que o espaço da unidade, em si, continua o mesmo.

\footnotetext{
${ }^{32}$ Diretor da Embraesp - empresa de consultoria imobiliária. Revista Tigre em Ação, Junho de 2004, p. 07.
} 
TABELA 04 - EVOLUÇÃO DAS ÁREAS ÚTEIS DE UNIDADES RESIDENCIAIS (APARTAMENTOS), CLASSIFICADAS POR NÚMERO DE DORMITÓRIOS. LANÇADAS NO MUNICÍPIO DE SÃO PAULO

\begin{tabular}{|c|c|c|c|c|c|c|c|c|c|c|}
\hline \multirow[b]{2}{*}{ Mês } & \multicolumn{2}{|r|}{2001} & \multicolumn{2}{|r|}{2002} & \multicolumn{2}{|r|}{2003} & \multicolumn{2}{|r|}{2004} & \multicolumn{2}{|r|}{2005} \\
\hline & Janeiro & Julho & Janeiro & Julho & Janeiro & Julho & Janeiro & Julho & Janeiro & Julho \\
\hline 1 dorm & 36,72 & 18,93 & 34,32 & 41,06 & 33,55 & 41,98 & * & 41,93 & 53,30 & $*$ \\
\hline 2 dorm & 51,10 & 54,12 & 52,12 & 49,90 & 54,05 & 59,68 & 54,52 & 51,35 & 49,96 & 50,53 \\
\hline 3 dorm & 91,63 & 85,01 & 59,30 & 77,23 & 84,35 & 84,63 & 139,90 & 113,87 & 80,60 & 87,83 \\
\hline 4 dorm & * & 178,43 & * & 285,91 & 158,94 & 164,45 & * & 307,15 & 173,46 & 134,90 \\
\hline
\end{tabular}

Fonte: Embraesp, relatórios mensais, 2001/2004

\section{APARTAMENTO PAULISTANO: UM PRODUTO IMOBILIÁRIO}

As hipóteses explicativas do surgimento da verticalização em São Paulo passam, necessariamente, pelo campo da produção da habitação. Inserida no modo de produção capitalista, ela obedece às mesmas condições inerentes à produção de uma mercadoria qualquer, tendo, no entanto, duas características específicas, que constituem obstáculos ao desenvolvimento do capital. A primeira se refere ao longo período de rotação, e a segunda à necessidade de uma base fundiária. A partir desta definição podemos identificar atualmente o produto imobiliário, objeto do mercado imobiliário. 
O produto imobiliário, termo utilizado na linguagem do setor imobiliário, é concebido para satisfazer necessidades e desejos do consumidor. Segundo RIGHI e CASTRO ${ }^{33}$, com um processo que resulte na

venda de um determinado produto, estratégias de marketing visam expressar os desejos dos compradores potenciais através:

1. Da análise de mercado através da demanda e oferta;

2. Da avaliação das possibilidades de diferenciação competitiva frente às outras empresas;

3. Do estudo de viabilidade e desenvolvimento de novos produtos;

4. Das estratégias de comercialização.

Para melhorar a relação entre a arquitetura e o marketing algumas considerações merecem destaque. Segundo COSTA:

A propagando imobiliária é hoje um discurso presente e ativo na formação de valores, recriando, codificando e recodificando os hábitos e preferências do consumo do espaço, assim como a significação desta mercadoria especial como mediadora de relações sociais. Compreender os mais amplos e diversos significados que o produto imobiliário pode assumir para seu público consumidor é o objetivo principal do marketing nas empresas de incorporação. Cabe a pesquisa de mercado a identificação não só das formas materiais que o

\footnotetext{
33 Dados extraídos de RIGHI, R.; CASTRO, L. G. R. “O produto imobiliário e a arquitetura contemporânea em São Paulo.” V ENCONTRO DA LATIN AMERICAN REAL ESTATE SOCIETY. 2005, São Paulo. Anais. Biblioteca Secovi. São Paulo, 2005.
} 
produto possa assumir, mas também as suas possíveis imagens, os signos que possuam trânsito, penetração em identificáveis nichos específicos de demanda. É neste sentido que o profissional de marketing se introduz como o emissor das representações dos produtos imobiliários, como produtor de sentido do espaço, papel que socialmente parecia até aqui ser atribuído ao arquiteto. ${ }^{34}$

LOUREIRO e AMORIM, também discutem sobre a relação do marketing e da arquitetura no mercado imobiliário quando concluem que através dos atributos anunciados, expectativas em torno do morar são criadas e recriadas alimentando a formulação de programas arquitetônicos e constituindo certa cultura do morar. É a partir do entendimento geral que a casa ideal oferece conforto, segurança, privacidade e abriga os sonhos de seus moradores, que as estratégias de marketing, baseado nestas características, vinculam a compra do imóvel à realização de um sonho. E é exatamente deste sonho e da recriação constante de um ideal de morar que a indústria imobiliária se estrutura, introduzindo constantemente novos produtos no mercado que tentam satisfazer as expectativas dos consumidores e também criar novas necessidades.

Neste mercado, a propaganda exerce um papel fundamental, ao manter viva esta necessidade constante pela aquisição de um lugar perfeito para morar. (...) Nas últimas décadas do século $X X$, novas formas de construir o sonho do mundo doméstico foram facilitadas pelo uso de novas tecnologias de

\footnotetext{
${ }^{34}$ Dados extraídos de COSTA, A. "A imagem da Arquitetura e a arquitetura da Imagem: uma investigação acerca da construção dos discursos na produção do espaço urbano". Dissertação de mestrado apresentada à FAU - USP. São Paulo, 2002.
} 
informação: modelo virtuais em 3-D e e-comerce são algumas ferramentas de marketing para atingir os consumidores de classe média. Estas tecnologias oferecem um experiência quase real do espaço futuro - algo como um portal para o mundo ideal. Paralelo aos espaço virtual ganhou força, nos últimos anos, a estratégia do "apartamento mobiliado", que também reproduz um ideal de morar quase próximo do real. (...) Estas peças promocionais oferecem as vantagens de um mundo ideal que o consumidor é induzido a consumir. Desta forma permite ao empreendedor estar atento às necessidades de consumidores e amoldar seus sonhos. ${ }^{35}$

A propaganda imobiliária também tenta constituir uma determinada "cultura do morar". Soma-se a isto o fato de que a moradia possua além da função pragmática uma função simbólica. Ainda que a casa seja primariamente um objeto funcional, ela serve a uma gama de propósitos, aos quais valores podem ser atribuídos, tanto tangíveis e quantificáveis, como valor econômico, de troca, de uso, como outros que não são quantificáveis de forma direta, como o valor sentimental, valor estético e o valor simbólico, que estariam referenciados às comunicações interpessoais entre pais e filhos, e entre membros do mesmo grupo social ou profissional.

Sob esta ótica do produto imobiliário concebido para satisfazer necessidades e desejos do consumidor, a estratégia para identificação destas demandas é a realização e sustentação de vendas; a chave para o marketing profissional é entender as reais necessidades dos consumidores e atendê-las melhor que

${ }^{35}$ LOUREIRO, C.; AMORIM, L. “Dize-me teu nome, tua altura e onde moras e te direi quem és: estratégias de marketing e a criação da casa ideal - parte 1". ARQUITEXTOS: Disponível em www.vitruvius.com.br/arquitextos/arq000/esp281.asp. no 281, fevereiro de 2005. 
qualquer outro produto. Estabelecer o mercado pelo "lado da demanda", implica colocar como dependente, o "lado da oferta". Isto implica que o processo de produção é estruturado para a realização do produto para o mercado, para atendimento dos consumidores agrupados segundo perfis de hábitos e padrões de consumo em segmentos de mercado. A partir desta lógica do mercado tais pesquisas de mercado realizadas acabam por apresentar um quadro das necessidades dos moradores, na grande maioria das vezes simplista com informações rasas e sem conteúdo, já que a formatação deste produto possui uma relação subordinada à sua realização no mercado ou às suas vantagens comparativas em termos de venda.

No desenvolvimento do produto imobiliário, CíRICO afirma:

A preocupação com o custo leva a extrema otimização das áreas que irão compor o imóvel, numa disputa pelo mercado, onde o valor de venda do metro quadrado do imóvel é que vai determinar o tamanho final, e enquadrá-lo na fixa de mercado que se pretende atingir. ${ }^{36}$.

Interessante o ponto de vista explorado pelo autor sobre o processo de desenvolvimento do projeto [o que chamamos de produto imobiliário] destinado a edifícios de apartamentos ofertados pelo mercado imobiliário, na qual o usuário final não participa da fase da elaboração do projeto e tão pouco o arquiteto tem recursos para uma ampla pesquisa dos moradores futuros. Neste caso a maioria dos empreendimentos é idealizada a partir de uma lógica na qual o atendimento às necessidades do usuário

\footnotetext{
${ }^{36}$ CíRICO, L. A. "A importância do projeto no desenvolvimento de espaço das áreas privativas dos apartamentos". In: IX ENTAC - ENCONTRO NACIONAL DE TECNOLOGIA DO AMBIENTE COSNTRUÍDO, Paraná. Anais. São Paulo, 2002. Biblioteca Secov
} 
final não é o objetivo último do processo e sim o sucesso de venda e o lucro do empreendedor. Por outro lado, o usuário a procura de um imóvel tem a sua disposição um gama de opções, tanto no que se refere ao tamanho, programa, localização ou preço final do imóvel que, na maioria das vezes, a decisão da escolha fica reduzida ao preço e, portanto as reais necessidades e expectativas dos usuários em relação a sua moradia raramente são atendidas.

Algumas pesquisas pós-ocupação de imóveis residenciais indicam esta teoria. O comportamento do consumidor, em relação a aspectos de espaço interno do apartamento, algumas vezes se mostrou contraditório. Vários consumidores compraram apartamentos em função da quantidade de dormitórios, mas abriram mão deste número em função da utilização mais funcional do espaço. Este comportamento implica em dois tipos básicos de reclamações em relação ao projeto:

1. Insatisfação por ter que abrir mão de espaços para ampliar outros mais fundamentais;

2. Insatisfação por não poder modificar e ter que se contentar com espaços aquém da sua necessidade.

Morar em apartamentos na cidade de São Paulo é um fato consolidado, pois sua produção nos primeiros cinco anos dá década de 2000 foi quase dez vezes maior que a produção de casas ${ }^{37}$.

\footnotetext{
${ }^{37}$ Dados extraídos da Embraesp. Revista Tigre em Ação, Junho de 2004, p. 03.
} 
Desde suas origens na cidade de São Paulo, notamos que o controle da produção dos edifícios de apartamentos tem estado nas mãos de especuladores, principalmente a partir de Lei do Inquilinato. Sempre considerados como mercadoria, tais apartamentos chegaram ao final do século 20 apresentando a mesma tipologia de tempos atrás em áreas até $50 \%$ menores que nos anos 1950 . Este "tipo", sob a alegação de ser um resultado projetual economicamente viável e que atende às necessidades dos moradores foi, nas últimas três décadas do século 20 , comercializado em grande escala. Os apartamentos elaborados por "arquitetos de atelier" freqüentemente oferecem a mesma organização espacial. Este quadro se acentuou, principalmente a partir dos anos 1970, quando se observou a especialização de uma chamada arquitetura comercial subordinada, portanto, às regras de mercado. SEGAWA observa:

(...) que a grande maioria de edifícios do gênero é medíocre, virtualmente transformando um juízo de origem preconceituosa num argumento irrefutável (...). ${ }^{38}$

Sobre a relação entre a qualidade e a produção feita pelo mercado imobiliário, FONSECA, indicou sua hipótese de trabalho como sendo:

a constatação da defasagem de acúmulo, experiência e maturidade existente no mercado imobiliário entre o projeto, o desenho e a execução dos imóveis; e da idealização, o marketing e a comercialização desses produtos. O entendimento deste desequilíbrio revelou, como um mercado que se mantém

\footnotetext{
${ }^{38}$ SEGAWA, H. “Obviedade e mediocridade”. São Paulo, Revista Projeto, no 141, Editora Pini, 1991, p. 63.
} 
forte, apesar de três décadas de crises pendulares, não foi e não é capaz de produzir, do ponto de vista da arquitetura, uma qualidade que tenha a mesma expressividade dos quantitativos que gerencia e dos volumes financeiros que gera. $^{39}$

Interessante também é a abordagem é traçada por Fernando Serapião em sua matéria "Os edifíciosfantasmas e seus ornamentos delinquentes" sobre a produção recente de edifícios de apartamentos na cidade de São Paulo. Segundo o autor nas últimas décadas acelerou-se a transformação dos novos edifícios de apartamentos de São Paulo em produtos que podem oferecer opções de estilos desvirtuados: neocolonial, neomediterrâneo, neomoderno, art déco e mais comum deles, o neoclássico.

O establishment arquitetônico chia e a maior parte do público consumidor aprova, enquanto construtores, incorporadores e imobiliárias estão de olho nas vendas. A questão parece menor e mesquinha, pois se trata de edifícios privados. No entanto, pode ser vista como uma metáfora da visão que a sociedade tem do arquiteto: uma profissão com muita serventia na arte de adornar fachadas conforme tendências da moda. ${ }^{40}$

Já RIGHI e CASTRO, nos apresentam a seguinte opinião sobre este assunto: para eles, o elemento estético-formal no projeto de arquitetura é evidente para a formatação do produto imobiliário:

\footnotetext{
39 Dados extraídos da Tese de Doutorado FONSECA, A. C. P. "A promoção imobiliária privada e a construção da cidade de São Paulo 1970/2002". FAU - USP. São Paulo, 2004, p. 244.

40 Dados extraídos da Tese de Doutorado FONSECA, A. C. P. "A promoção imobiliária privada e a construção da cidade de São Paulo 1970/2002". FAU - USP. São Paulo, 2004, p. 244.
} 
Nele está a idéia de estilo de vida como consumo diferenciado, elemento social distintivo. Assim, a comercialização do produto imobiliário envolve um conjunto de valores que conferem status, prestígio, distinção a seu detentor. Os elementos do projeto mais valorizados envolvem uma forte tendência ao reducionismo das características estéticas do projeto de arquitetura a seus aspectos mais aparentes assimiláveis por um determinado público alvo, em termos de imagem exterior, ambientação paisagística, acabamentos internos e mesmo mobiliário. ${ }^{41}$

Em matéria ao jornal Folha de São Paulo, a lógica de mercado, expressa pelo lucro e custo é considerada o motivo da limitação de criatividade dos arquitetos e da pasteurização dos estilos utilizados na produção de apartamentos na cidade de São Paulo:

Redução de custos, margem de lucro e pesquisas de mercado são elementos que definem os prédios residenciais construídos em São Paulo. O resultado desta lógica empresarial é que as fachadas de muitos edifícios da maior cidade brasileira parecem saídas de uma linha de montagem. (...) Isso é um debate estético que precisa de bagagem cultural sólida. ${ }^{42}$

\footnotetext{
${ }^{41}$ Dados extraídos de RIGHI, R.; CASTRO, L. G. R. “O produto imobiliário e a arquitetura contemporânea em São Paulo." V ENCONTRO DA LATIN AMERICAN REAL ESTATE SOCIETY. 2005, São Paulo. Anais. Biblioteca Secovi. São Paulo, 2005.

42 SIQUEIRA, D. , CUNHA, J. "Lógica de mercado padroniza arquitetura”. FOLHA DE SÃO PAULO, São Paulo, 15 de janeiro de 2006. Caderno Dinheiro, B12, seção arquitetura.
} 
Nesta matéria alguns atores do mercado imobiliário paulistano exprimem seus pontos de vista e seus papéis no processo de produção de edifícios residenciais. De maneira geral os incorporadores, que objetivam neste processo principalmente o lucro e a venda rápida do produto, estão muito mais interessados nos coeficientes de aproveitamento do terreno e otimização dos espaços, do que nos tipos de fachadas, quando a questão é o projeto de arquitetura. Por sua vez, o cliente valoriza muito o tipo de fachada que o edifício tem apesar desta questão ser bastante polêmica, já que alguns pesquisadores indicam que a população desconhece o que seja estilo.

Segundo a matéria, a definição do projeto parte da:

- Pesquisa de mercado para definição do tipo de edifício;

- Consulta de legislação para definição de gabarito e implantação no lote;

- Estudo de viabilidade econômica para o cálculo do retorno financeiro do empreendimento;

- Elaboração do projeto de arquitetura na qual adapta a encomenda da incorporadora às normas da prefeitura;

- A moda vigente, ou alguns estilos, viram os preferidos das construtoras por alguns anos até sua substituição em decorrência da sua popularização e banalização.

Este quadro nos mostra bem o papel secundário do arquiteto neste processo de produção e definição do projeto dos edifícios no mercado imobiliário, na qual sua função se restringe basicamente à definição de um aproveitamento máximo de áreas, implantações também maximizadas e finalmente a idealização de fachadas atrativas ao público alvo. Ainda segundo a matéria, os profissionais arquitetos contratados 
geralmente são aqueles que questionam pouco e resolvem bem a fórmula econômica do empreendimento.

Já o marketing imobiliário tem ganhado destaque neste processo de produção de edifícios nos últimos anos, visto que o volume gasto com marketing supera em até 06 vezes a remuneração do profissional arquiteto. SIQUEIRA e CUNHA afirmam na matéria publicada no jornal Folha de São Paulo que as incorporadoras de São Paulo gastam entre 3 a $6 \%$ do VGV [Valor Geral de Venda] de um empreendimento imobiliário com marketing. Isso representa até seis vezes mais do que elas pagam por projeto arquitetônico. Um arquiteto recebe em média, de 0,5\% a 1,5\% do VGV. Este gasto varia de acordo com o tamanho do empreendimento e é destinado para ações de divulgação que vão desde anúncios publicitários e material humano à construção de apartamento decorado e distribuição de folhetos luxuosos.

Outra justificativa do uso do repertório clássico nas fachadas dos edifícios residenciais espalhados pela cidade de São Paulo, e também pelo Brasil afora, se refere aos custos reduzidos de sua execução. Segundo arquitetos, fachadas neoclássicas oferecem vantagens econômicas às incorporadoras. A simplicidade dos revestimentos reduz os custos de construção, já que os materiais utilizados para sua execução se resumem em argamassa e pintura. A popularização deste recurso estético utilizado para as fachadas dos apartamentos se deve em grande parte aos baixos custos que este oferece. É possível encontrar edifícios residenciais neoclássicos que variam seu preço de $\mathrm{R} \$ 100$ mil até R\$ 5 milhões. 


\subsection{SÃO PAULO E O PDE \\ PLANO DIRETOR \\ ESTRATÉGICO}

O Plano Diretor Estratégico - PDE, aprovado em 2002, estabeleceu um processo de planejamento iniciado pelos planos regionais. Para os grandes desafios urbanísticos que a cidade enfrentará no século 21, o PDE pretendeu definir objetivos que deveriam ser alcançados até 2012 e uma estratégia para atingir os resultados esperados. Foram formuladas diretrizes para as políticas públicas, regulamentadas as regras para atuação dos agentes imobiliários privados, instituídos os novos instrumentos urbanísticos criados pelo Estatuto da Cidade para cumprir a função social da propriedade, estimular a produção habitacional e obter contrapartidas do mercado para financiar a urbanização das áreas periféricas, definido um novo sistema de transporte coletivo e instituído um processo de planejamento, com controle social e descentralização. A meta-síntese do PDE foi de reduzir as desigualdades territoriais urbanas e sociais.

O diagnóstico da cidade no final do século 20 revelou o agravamento em escala ampliada de processos fortes de exclusão territorial que, além de gerarem a precarização das condições de vida urbana, criam enormes deseconomias para a cidade como um todo.

\section{O BINÔMIO SOLO CRIADO / OUTORGA ONEROSA: ANÁLISE DO IMPACTO DO COEFICIENTE DE APROVEITAMENTO BÁSICO COMO INSTRUMENTO DO PDE}

O processo de crescimento das cidades em área e densidade de construção provoca a valorização dos terrenos que lhe dão suporte. A demanda por áreas adicionais para construção e o caráter não reprodutível em grande escala do solo [físico] resultam numa elevação dos respectivos preços. 
Neste contexto, o mercado de terras se caracteriza por uma demanda que se expande e esbarra numa relativa rigidez da oferta. Esta rigidez está relacionada fundamentalmente a três fatores:

- concentração da propriedade fundiária;

- dificuldade de acesso à áreas ainda não ocupadas por ausência de infraestrutura;

- restrições impostas pelo zoneamento. Cada um destes fatores tem sua própria dinâmica e não necessariamente estão presentes simultaneamente como elementos restritivos da oferta nos casos concretos das cidades brasileiras e em especial em São Paulo.

Além disso, nem sempre atuam na mesma direção no que se refere à elevação de preços. A concentração de terras nas mãos de poucos proprietários pode atuar no sentido de elevar os preços, enquanto a falta de acessibilidade pode resultar em preços baixos; um zoneamento muito restritivo pode também contribuir para impedir que os preços se elevem.

A pressão da demanda por solo para construção, no entanto, resulta geralmente em mais valias urbanas se obras de infraestrutura viabilizarem maior acessibilidade a estas áreas, e mudanças no zoneamento permitirem maiores densidades de construção.

Geralmente o custeio deste acesso [estradas, ruas, avenidas, túneis, pontes, rede de esgotos, iluminação, abastecimento de água etc.] tem sido realizado com recursos públicos. No entanto, a valorização que os terrenos [agora dotados de infraestrutura] obtém, é apropriada pelos proprietários destes lotes, exceto nos raros casos em que se aplicava o dispositivo de contribuição de melhoria . 
O que era investido poderia ser recuperado pela valorização criada e o respectivo pagamento feito pelos proprietários dos imóveis beneficiados.

Mas nem sempre este se aplicou no Brasil de forma generalizada. Embora não disponhamos de informações mais precisas e abrangentes sobre esta questão para o caso de São Paulo é bem provável que a valorização provocada por obras pública seja apropriada integralmente, isto é, sem contrapartida, pelos donos dos imóveis beneficiados.

Esta valorização pode resultar também da simples mudança de uso nos terrenos já acessíveis, quando, por exemplo, um terreno que antes era considerado rural passa a ser urbano. Uma simples decisão como esta pode significar um expressivo aumento do valor dos lotes beneficiados. Trata-se da criação de mais valia sem a necessidade imediata de investimentos em infraestrutura, embora o uso urbano de uma área, antes de uso rural demande investimentos dessa natureza quando for utilizado no futuro.

No entanto o desenvolvimento urbano passava a ser matéria de legislação federal e o principio da função social da propriedade territorial urbana separava na prática o direito de propriedade territorial urbana e o direito de construir.

A existência das Operações Interligadas e também das Operações Urbanas em São incorporaram os princípios constitucionais em sua Lei Orgânica no início dos anos 90 não esperando sua regulamentação para todo o Brasil, onde se praticavam o solo criado e a outorga onerosa. 


\section{O SOLO CRIADO}

Em termos gerais solo criado significa uma concessão a um proprietário do direito de construir além da área de seu terreno. Em termos específicos é um conceito urbanístico que consiste em conceder a interessados direitos de construir utilizando parâmetros diferentes do estabelecido pela Lei de Zoneamento em vigor [ou de Uso e Ocupação do Solo], em troca de recursos financeiros para a construção de habitações de interesse social ou melhorias de infraestrutura viária, de saneamento básico etc. nas áreas onde tais concessões se realizam.

\section{A OUTORGA ONEROSA}

A outorga onerosa significa o pagamento de uma contrapartida econômica por aquele que recebe do poder publico um direito de construir - solo criado - que antes não possuía. A outorga onerosa prevista pelos artigos 28, 29, 30 e 31 da Lei Federal 10.257 de 2001 - Estatuto da Cidade - e definida nos artigos de 209 ao 216 do Plano Diretor Estratégico de 2002 do Município de São Paulo é um dos instrumentos de regulação do direito de construir na cidade. Até a aprovação do PDE, a prática da outorga onerosa consistia no pagamento de uma contrapartida pelos benefícios que um terreno obtinha geralmente por aumentos do coeficiente de aproveitamento, da taxa de ocupação e/ou da mudança de uso nas Operações Interligadas ou Urbanas. Por exemplo, se numa Operação Urbana um terreno possuía coeficiente de aproveitamento 2 e o projeto a ser construído necessitava de um aumento deste coeficiente para 4 esta mudança poderia ser autorizada - desde que o projeto arquitetônico e urbanístico tivesse sido aprovado anteriormente - mediante o pagamento à administração municipal de $50 \%$ da valorização ocorrida. 
Com a aprovação do Estatuto da Cidade em 2001 o município de São Paulo em seu Plano Diretor Estratégico de 2002 e da Lei 13.885 de 2004 de Uso do Solo introduziu o mecanismo da outorga onerosa de potencial construtivo adicional estabelecendo um coeficiente de aproveitamento básico, e um coeficiente de aproveitamento máximo.

O coeficiente de aproveitamento básico estabelecido foi diferenciado, isto é, não foi único, variando entre 1 e 2. O máximo, dependendo da zona poderia ser igual a 1, 2, 2,5 e 4 . Esta nova abordagem ao mesmo tempo em que reduzia direitos de construir ao estabelecer um coeficiente básico 1 em terrenos que pela legislação anterior tinham um coeficiente de aproveitamento de 2 ou mais, ampliava a possibilidade de construir - com outorga onerosa - para 4 em terrenos onde anteriormente se poderia construir apenas 1 ou 2. Este dispositivo permitia que em certas áreas onde o coeficiente de aproveitamento máximo fosse 4 as construtoras apresentassem projetos como antes ocorria com as Operações Interligadas. O mecanismo era basicamente o mesmo. Talvez esta possibilidade que favorecia as construtoras [mas não aos proprietários de terrenos que em alguns casos tiveram o potencial construtivo de seus terrenos diminuído] tenha contribuído para a sua aprovação na Câmara de Vereadores. Ao mesmo tempo em que o Plano Diretor estratégico de 2002 e a Lei 13.885 de 2004 estabeleciam os coeficientes básico e máximo, também fixavam os estoques de potencial construtivo residencial e não residencial em cada distrito da cidade. Foi estabelecido um total de área adicional de 9,769 milhões de $\mathrm{m}^{2}$ divididos em 6,919 milhões de $\mathrm{m}^{2}$ para fins residenciais e 2,850 milhões de $\mathrm{m}^{2}$ para fins não residenciais distribuídos entre os 91 distritos com as exceções de Anhanguera, Grajaú, Marsillac, Parelheiros, Raposo Tavares e áreas de proteção ambiental. 
A fixação de um estoque de potencial construtivo incorporou um elemento novo para o mercado imobiliário: tornou conhecida a oferta máxima de área de construção a ser adquirida pelos interessados. Nos Planos Diretores anteriores a magnitude da oferta era desconhecida.

\section{OS AVANÇOS NA INSTITUIÇÃO DOS COEFICIENTES BÁSICO E MÁXIMO E A REDUÇÃO DOS DIREITOS DE CONSTRUIR}

O Plano Diretor estratégico de 2002 estabelecendo os coeficientes básico e máximo e a outorga onerosa pelo uso do potencial construtivo existente entre ambos, na prática retirou de proprietários de imóveis direitos que os mesmos detinham pela legislação anterior. Ou seja, o Plano Diretor Estratégico de 2002 negou a existência de direitos adquiridos àqueles proprietários de imóveis que tinham coeficientes de aproveitamento superiores ao que veio a ser estabelecido como básico. O Plano Diretor de 2002 levou à prática o conceito de função social da propriedade territorial que transforma o direito de construir em atribuição do poder público e não algo inerente ao direito de propriedade privada do solo urbano. Sendo uma atribuição do poder público, o direito de construir pode ser reduzido ou ampliado aos proprietários privados dependendo do interesse publico relacionado com a dinâmica do desenvolvimento urbano.

Na proposta de Plano Diretor apresentada à Câmara de Vereadores em São Paulo em 1991 o princípio do coeficiente de aproveitamento único [e igual a 1] foi introduzido mas a proposta não foi aprovada pelo Legislativo. Cerca de dez anos depois, na discussão da proposta do PDE de 2002, a resistência de 
vários setores relacionados com o mercado imobiliário também ocorreu. Mas o interessante é que setores da área financeira do próprio governo municipal tinham restrições à medida.

Consideravam que se houvesse rebaixamento generalizado do coeficiente de aproveitamento dos terrenos seu valor de mercado diminuiria e haveria redução da receita do IPTU.

Como essa desvalorização ocorreria no conjunto do estoque de terrenos não edificados - e também nos edificados, pois o imposto é resultante da soma da alíquota aplicada sobre o valor da parte edificada e sobre o valor do terreno - e de uma só vez, esta perda não seria compensada pelos recursos originados no pagamento das contrapartidas financeiras de cada projeto aprovado e que necessitasse de coeficientes de aproveitamento superiores ao básico. Tais contrapartidas viriam pouco a pouco no ritmo do lançamento de projetos do mercado imobiliário.

Na realidade como os preços dos terrenos sofrem consideráveis oscilações dependendo dos ciclos do mercado imobiliário estas diferenças de preço causadas pela redução do coeficiente de aproveitamento parecem não terem sido percebidas nem pelos proprietários de imóveis e tampouco pelos empreendedores imobiliários que reforçam as seguintes percepções: 
- Antes da aprovação do Plano Diretor estratégico em 2002 as empresas exerciam o que eles mesmo chamam de "direito de protocolo" que significa protocolar projetos [obtendo a respectiva licença na SEHAB - Secretaria Municipal de Habitação] beneficiando-se de coeficientes de aproveitamento anteriores antes que os mesmos fossem rebaixados. Como o alvará de execução é válido por 3 anos e os projetos podem ser modificados dentro deste prazo, - sem contudo alterar as taxas de ocupação e os coeficientes de aproveitamento -, os empreendedores tinham estoque de projetos com licenças até 2005 ano no qual tem início o registro de receitas da outorga onerosa.

- Os preços dos terrenos parecem não ter caído em função da existência da outorga onerosa. Nas vezes em que o argumento da outorga onerosa foi apresentado na mesa de negociação entre o empreendedor e o proprietário argumento nas raras vezes em que foi utilizado não influiu no resultado final da negociação. Por outro lado, a cobrança da outorga onerosa parece não ter afetado a lucratividade das empresas.

A aprovação de um coeficiente de aproveitamento básico e um máximo no Plano Diretor Estratégico de 2002 em São Paulo parece não ter provocado um impacto negativo nos preços dos terrenos que perderam direitos de construção.

A fixação de um estoque máximo de potencial construtivo proporcionando aos agentes um horizonte quantitativo para o esgotamento da oferta parece ter provocado uma tendência de elevação nos preços dos terrenos devido a aceleração da demanda diante do processo "compremos agora antes que o 
estoque se esgote". De fato, em janeiro de 2010 o estoque de potencial construtivo para fins residenciais como já assinalamos já se havia esgotado em 15 dos 93 distritos da cidade de São Paulo, e para fins não residenciais em 5 distritos.

A arrecadação de contrapartidas financeiras tem crescido a partir de 2005 e até novembro de 2009 haviam sido arrecadados cerca de 420 milhões de reais.

Depois da aprovação do Plano Diretor Estratégico do Município de São Paulo em 2002, aplicou-se em todo o seu território o princípio da outorga onerosa e do solo criado. Se uma edificação ultrapassa o coeficiente de aproveitamento básico e deseja edificar até um máximo de 4 deverá pagar uma contrapartida financeira ao poder público.

Ao contrário das receitas do IPTU que tem uma existência contínua no tempo as contrapartidas financeiras oriundas da outorga onerosa se extinguirão quando o potencial adicional de construção determinado no Plano Diretor Estratégico do Município de São Paulo se esgotar. O fluxo destes recursos financeiros não será, portanto, contínuo. Aliás, em alguns setores da cidade o estoque já se esgotou e, portanto, a cidade já alcançou, naquelas áreas, seu perfil definitivo no que se refere à densidade de construção. No entanto, alterações futuras no Plano Diretor poderão conceder a estas áreas potencial construtivo maior, tudo dependendo das recomendações técnicas e condições políticas para que tal mudança se viabilize. Nesse caso, o grande perigo é que motivações de aumento na 
arrecadação suplantem as recomendações urbanísticas e as limitações de infraestrutura, especialmente de transporte e tráfego.

O Plano Diretor Estratégico de 2002 mostrou também que através do princípio da função social da propriedade a legislação urbanística pode separar claramente o direito de propriedade do direito de construir. Nesse caso a tese dos direitos adquiridos não se sustenta não podendo se sobrepor ao interesse público, ou possuir hierarquia superior à função social da propriedade. Portanto, direitos de construir existentes podem ser reduzidos sem que o proprietário do solo tenha direito à indenização pecuniária por mera frustração de expectativas. 


\subsection{O CASO ZARVOS}

O sobrenome Zarvos é conhecido em São Paulo há mais de 50 anos, após batizar um empreendimento construído no início dos anos 60 com apartamentos, escritórios e conjuntos comerciais. O conjunto Zarvos localiza-se na esquina da Rua da Consolação com a Avenida São Luiz, em frente à Biblioteca Mário de Andrade sendo um dos mais significativos trabalhos arquitetônico do arquiteto Júlio Neves.

O construtor, que durante anos dirigiu a empresa que leva o nome da família, é Tito Zarvos. Otávio Zarvos é filho de Tito. No início da década de 90, junto com seu irmão, engenheiro civil, criou sua própria construtora e assim, nunca chegou a trabalhar com o pai. A formação de Otávio é em administração de empresas.

Seus primeiros trabalhos surgiram a partir a aprovação da lei que liberava a construção de vilas. Foram diversas casas construídas principalmente no bairro Cidade Jardim, junto ao Morumbi, zona sul de São Paulo. Em sua maioria, projetos de alto padrão, mas sem agregar uma arquitetura de repertório. Com o tempo, o olhar de Otávio se apurou e uma dessas vilas foi projetada por Marcos Acayaba. Anos depois, com a instabilidade do mercado, o irmão de Otávio desiste da sociedade. Surge nesse período seu interesse pela diversidade oferecida no bairro da Vila Madalena, zona oeste da cidade. Também esgotado de construir e desejando apenas incorporar, Otávio ainda executa na Vila Madalena, o prédio em que está instalado hoje. Sua vontade era colocar em prática os conceitos em que acreditava e que trariam qualidade de vida, como morar perto do local de trabalho e exercer suas atividades em locais agradáveis e informais. Esta inspiração veio de sua visita em empresas na Califórnia, principalmente do setor pontocom, em que os ambientes de trabalho já se transformaram. 
De fato, se a edificação não tem exatamente uma arquitetura de vanguarda, também não lembra em modo algum os espaços corporativos costumeiramente oferecidos pelo mercado imobiliário. Com tijolos e estrutura metálica aparentes, unidades com mezaninos e um grande átrio central, o espaço desenhado por Valter Gola inspira-se nos lofts.

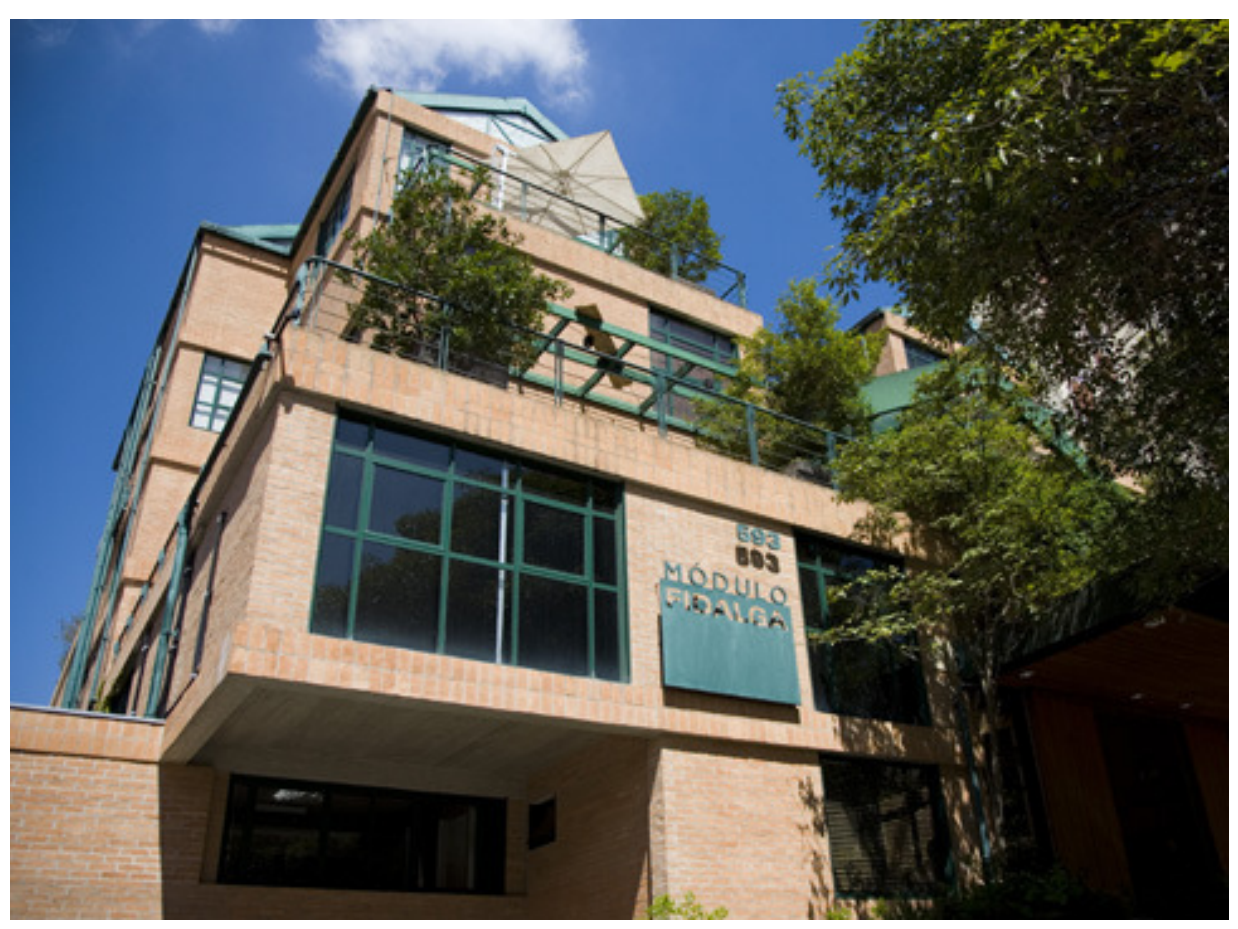

Fig. 50 - Conjunto Módulo Fidalga, sede da Idea!Zarvos Rua Fidalga, 593, sala 08 - Vila Madalena 
A empresa de Zarvos não se consagrou sozinha. Graças a um encontro ocorrido em 2004 no escritório dos arquitetos Reinach e Mendonça, Otávio Zarvos foi apresentado a José Eduardo Cazarin, publicitário e proprietário da imobiliária Axpe.

A Axpe surgiu no mercado em 2003. Cazarin era o dono e único funcionário. Meses depois, alugou o primeiro imóvel de sua cartela. Em janeiro do ano seguinte fez sua primeira venda. Aos poucos, a Axpe ganhou fama e se consolidou.

Hoje a imobiliária abriga 30 corretores de imóveis, todos vindos de outras áreas. Segundo o proprietário, nenhum deles era corretor antes de trabalhar na Axpe. A maioria arquitetos publicitários. Há também engenheiros e economistas. Houve a tentativa de trazer alguns corretores, mas sem êxito. Sendo assim, a condição imposta por Cazarin é que todos tirem a licença que permite exercer regularmente a atividade. Eles passam por um treinamento interno, com diversos cursos, que vão de aulas de história da arquitetura e do design ao estudo e domínio da legislação municipal. A idéia é que os corretores possuam o mesmo nível cultural dos compradores. Os valores dos imóveis oferecidos pela Axpe são um pouco mais elevados do que normalmente se encontra no mercado. 0 valor mínimo anunciado para locação é de $\mathrm{R} \$ 3.000,00$ e de $\mathrm{R} \$ 300.000,00$ para venda. Para Cazarin, lidar com um valor menor, não é rentável. O trabalho para locar ou vender um imóvel, independente do valor, é o mesmo. Como sua operação de trabalho é cara, tem que haver esta linha de corte. 
Como já citado, no início de 2004, Zarvos finalizava a construção do conjunto de salas na Vila Madalena, o Módulo Fidalga, onde está a sede de sua atual empresa. Desde o início, a intenção sempre foi de construir o conjunto todo para locação. O mesmo foi feito e $100 \%$ alugado pela Axpe.

Depois da bem-sucedida operação imobiliária de locação, Zarvos sugeriu a Cazarin a parceria numa nova incorporadora. Na união de forças, os papéis estavam bem definidos. Cazarin ficou responsável pela criação da marca, direção da imagem, conceito da empresa e das vendas. Nada de stands, nem apartamentos decorados. Foram contratados publicitários independentes para executar as campanhas, baseadas em prospectos. Cazarin ensina que os bons publicitários estão em agências grandes. Como a verba do mercado imobiliário só dá acesso a agências de pequeno e médio porte, este acaba assessorado por profissionais não tão qualificados. A alternativa foi buscar os free-lancers, que estão fora do circuito.

A direção da incorporação e o acompanhamento das obras ficariam na mão de Zarvos. Dois outros sócios foram chamados: Rafael Canto Porto, dono da CP3 - construtora de imóveis de alto padrão e Tonico Canto Porto, sobrinho de Rafael, oriundo do mercado financeiro. A empresa foi batizada com o nome de Movimento Um. 


\section{DIRETRIZES DA MOVIMENTO UM}

Os empreendimentos da Movimento Um seguiram alguns princípios. O primeiro deles foi a variação no tamanho das unidades dentro do mesmo empreendimento. Para Zarvos, não há nenhum problema em ter apartamentos de $80 \mathrm{~m}^{2}$ em um mesmo prédio com outro de $300 \mathrm{~m}^{2}$. É uma determinação surpreendedora. Segundo o incorporador, quando ocorrem as primeiras reuniões com os arquitetos, eles logo perguntam qual o tamanho das unidades. Ninguém está acostumado a esta falta de parâmetro. Outra característica deste manifesto imobiliário foram os edifícios com poucas unidades. Este, aliás, foi o mote que fez Zarvos procurar Cazarin. Ele percebeu a oportunidade de mercado: de um lado, os grandes terrenos disputados pelas incorporadoras estavam se esgotando; de outro, a cidade ofertava inúmeros lotes pequenos, ideais para prédios de escala reduzida e imagem diferenciada. Há empreendimentos em terrenos de $650 \mathrm{~m}^{2}$ em que o valor geral de vendas (VGV) não ultrapassa 10 milhões de reais.

Apartamentos individualizados são outra regra. A partir de algumas premissas técnicas que Zarvos impõe aos projetos, o comprador tem completa flexibilidade para rearranjar o espaço interno, predefinido pela proposta arquitetônica. Por uma questão de facilidade, honorários e especialização, Zarvos mantém na empresa uma equipe de arquitetos que dá assistência ao futuro morador. Em outras palavras, são eles que definem mudanças internas, claro que informando os autores, pois alterações podem trazer impacto, por exemplo, nas fachadas. Na união com Cazarin, a flexibilidade foi uma insistência de Zarvos, convencido de que as unidades deveriam ser adaptadas a necessidades atuais ou futuras. As áreas molhadas não possuem canos de esgoto posicionados sobre o forro do apartamento 
de baixo, como o usual. Elas são sempre resolvidas com a suspensão do piso na área do box. Em alguns edifícios, shafts vazios levam a liberdade a graus extremos: um banheiro, por exemplo, pode estar em qualquer lugar. Na maioria dos casos, a tubulação aparente na fachada adquire contornos interessantes. O único elemento não flexível é a varanda.

Outro fator que balizou a Movimento Um foi a localização dos terrenos: são todos muito próximos, no bairro da Vila Madalena. Como Zarvos é conhecido na região, facilitou a credibilidade e ajuda na compra dos terrenos e venda dos apartamentos.

Outra diretriz da incorporadora é apostar na valorização do investimento, ou seja, utilizar a arquitetura de repertório para criar um objeto de desejo para aqueles consumidores que, no futuro próximo, pagarão mais pelas unidades - aliás, a mesma lógica de trabalho da Axpe. Zarvos já havia construído na Vila Madalena uma vila com Cristina Xavier, além de um prédio de apartamentos com Luiz Fernando Rocco. Mas Cazarin propunha procurar arquitetos mais jovens, exatamente aqueles cuja obra desafia o mercado. Até então, Zarvos não tinha conhecimento dos escritórios Andrade Morettin e Grupo SP, por exemplo. Qualidade arquitetônica - outro princípio - deriva, naturalmente, do anterior. A proposta consistia em realizar edifícios acessíveis dentro da faixa de público alvo - o preço médio do metro quadrado inicialmente era de 6,5 mil reais e agora gira em torno de 10 mil reais - e viáveis através da economia de custos que consideram desnecessários. Algumas edificações, por exemplo, possuem só um elevador. Não há área de lazer, salões de festas nem espaço gourmet. As áreas comuns são reduzidas ao máximo. No térreo, por exemplo, há um apartamento-casa, um dúplex que ocupa com jardins privativos 
todos os recuos laterais e de fundo. A execução fica a cargo de pequenas e médias construtoras, acostumadas à maior sofisticação nos acabamentos.

Qualidade de vida encerra a lista dos princípios. Isso implica desde o tamanho das aberturas das unidades e sua localização até a gentileza urbana. Este último item se confirma sobre um trauma de execução feito por Zarvos. Em uma de suas obras, o terreno possuía duas ruas e aquela que não cedeu acesso à edificação foi fechada, através de enorme muro. Na época, seu pensamento dizia que lá era o fundo. Hoje se recrimina, pois tem consciência de que isolou parte da cidade.

\section{O PRIMEIRO PROJETO}

O terreno da Rua Aimberê, em Perdizes foi escolhido para receber o primeiro prédio da Movimento Um, entregue no segundo semestre de 2009. O projeto foi objeto de um concurso fechado entre três escritórios que nunca haviam trabalhado com edifícios residenciais, mas segundo Zarvos foram préselecionados pelo destaque em concursos de arquitetura e louváveis críticas na mídia especializada. Concorreram: Andrade Morettin, Una e Triptyque. Este último ganhou a preferência dos empreendedores e imediatamente começou a desenvolver o projeto. Zarvos costuma ter reuniões semanais com os projetistas nas quais lança desafios, e espera respostas para dali a sete dias.

Problemas no andamento do desenho levaram os incorporadores a rever sua decisão e repassar o projeto para Andrade Morettin. Segundo Cazarin, não houve problema algum em relação a esta mudança. Na época, o Triptyque não estava organizado para dar as respostas no ritmo que esperavam. Confiando no trabalho deles, foram chamados na sequência para criar outro edifício. 
Não era e não é interessante para Zarvos trabalhar com especialistas em prédios de apartamentos, que aprovam rápido e fazem o que o mercado espera. Seu desejo é obter da arquitetura autoral uma resposta contemporânea e de repertório. Como esses escritórios nunca trabalharam com o mercado imobiliário, a empresa de Zarvos dá todo o suporte de legislação e construção para que criem com segurança. Antes de iniciar um projeto, Zarvos esmiúça todas as possibilidades de legislação, analisa as vistas importantes, os vizinhos etc. Na primeira reunião com os arquitetos, um roteiro preciso é apresentado.

No prédio de Andrade Morettin, o destaque são as unidades intercaladas, que segundo os arquitetos, remetem à análise do Downtown Athletic Club feita por KOOLHAAS em Delirious New York ${ }^{43}$. Em suma, ele conclui que um prédio em altura, independentemente do volume blocado externo, pode atender a organizações internas variáveis, tornando-se um "condensador social". Seria o fim do andar-tipo. Antes de aportar na Aimberê, a diversidade de soluções nos pavimentos rodou o mundo civilizado, sob a inspiração do arquiteto holandês. Em São Paulo, ganhou o toque de Vinícius Andrade e Marcelo Morettin no volume com recortes, que aparecem no acesso de pedestres e, sobretudo, na grande fenda da lateral do prédio. O cruzamento entre os acessos de pessoas e de veículos resulta num movimento interessante, criando uma topografia artificial.

\footnotetext{
${ }^{43}$ Relação apontada pelos arquitetos Andrade e Morettin na edição 353 da revista Projeto Design. KOOLHAAS, Rem. Delirious New York: a retroactive manifesto for Manhattan. New York, The Monacelli Press, 1994. [ Nova York Delirante: um manifesto retroativo para Manhattan. São Paulo, Cosac Naify, 2008. P.180 - 187]
} 


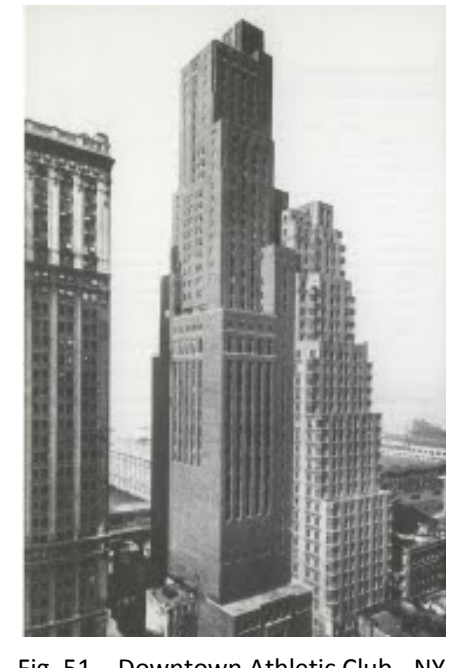

Fig. 51 - Downtown Athletic Club - NY 1931, Starret \& Van Vleck

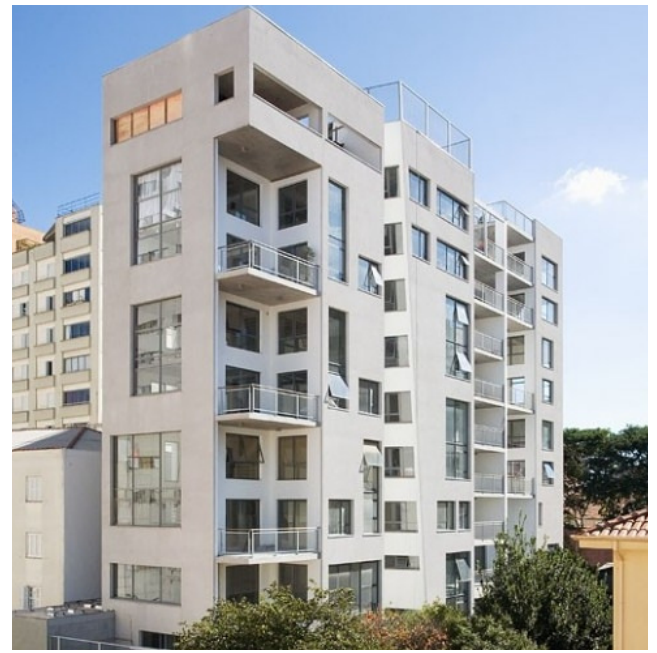

Fig. 52 - Edifício Aimberê 1749 - São Paulo

2009, Andrade e Morettin

Após o edifício Aimberê 1749, a Movimento Um realizou mais três incorporações. Destas três, duas foram construídas. A primeira foi encomendada diretamente ao Triptyque. Batizado de Fidalga 727, o prédio fica na rua de mesmo nome no bairro da Vila Madalena. $O$ entrono imediato é rodeado por sobrados antigos e discretos que exibem marquises das garagens com apoios em V, réplicas vulgares da liberdade estrutural do modernismo brasileiro. Mantendo a atenção nos apoios, vale destacar no Fidalga 727 , as colunas em $X$ - que na verdade mais buscam efeito do que causa, além de também remeter a Koolhaas, particularmente ao projeto que ele submeteu ao concurso da Biblioteca de Paris, vencido por Dominique Perrault. 
Já o edifício na Rua Simpatia, 236 foi encomendado ao escritório Grupo SP, de Álvaro Puntoni e João Sodré. O escritório havia procurado o grupo espontaneamente, pedindo opinião sobre um projeto residencial que imaginara para um terreno à venda na região. Eles não compraram o lote que os arquitetos tinham em vista, mas chamaram o grupo para desenhar outro edifício, entregue no primeiro semestre de 2011. O projeto consiste em dois blocos de massa semelhante interligados por passarela central, onde está também a circulação vertical. De todos os empreendimentos da Movimento Um, este é o de linguagem mais próxima à da arquitetura da Escola Paulista: ênfase estrutural, empenas laterais contrapostas às fachadas envidraçadas e a aplicação do painel artístico - de Andrés Sandoval - além da busca do prisma puro.

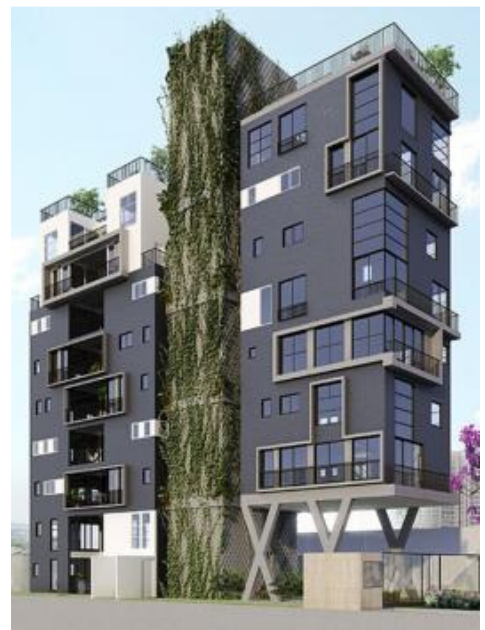

Fig. 53 - Edifício Fidalga 727 - São Paulo 2011, Triptyque

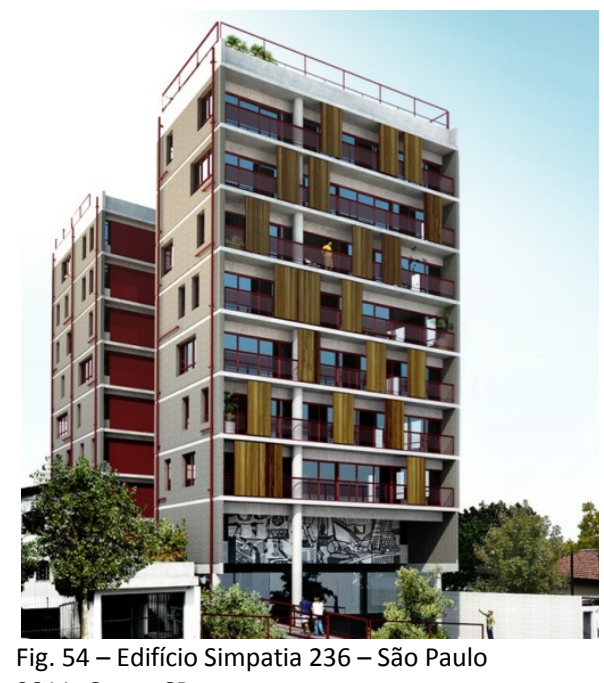

2011, Grupo SP 
Em entrevista ao arquiteto Fernando Serapião para a revista PROJETO DESIGN ${ }^{44}$, Cazarin exibe uma reportagem que destaca o arquiteto Puntoni na revista Monocle; as duas cabeças da Movimento Um buscam a contemporaneidade e esperam mais inovação nos desenhos dos edifícios. Para Serapião, Zarvos afirma:

Perto do que acontece lá fora, estamos ainda muito atrás.

Ainda em relação aos arquitetos escolhidos, Cazarin e Zarvos concordam que na maioria das vezes, esse tipo de profissional não sabe se fazer visível. Cazarin afirma faltar o marketing da arquitetura, exceto a equipe do Triptyque. Com a divulgação, Cazarin e Zarvos passaram a ser assediados por vários arquitetos. Com a crise internacional, inclusive os estrangeiros buscaram Zarvos.

O terceiro empreendimento da incorporadora foi o Girassol, projeto do escritório Frentes Arquitetura, de José Alves e Juliana Corradini. Sabendo que a Movimento Um buscava profissionais, a dupla de arquitetos procurou Zarvos diretamente. O prédio proposto apresentava desenho forte com a intenção de se destacar pela implantação de esquina e pela cor intensa, que mescla tons avermelhados. Este edifício, não foi construído.

\footnotetext{
${ }^{44}$ Revista PROJETO DESIGN n. 353 - Julho 2009. Seção Entrelinhas - "Mudanças de Ares”, por Fernando Serapião. P. 68 - 79.
} 


\section{A IDEA!ZARVOS}

Um pouco antes de integrar a Movimento Um, Zarvos já trabalhava individualmente em um edifício do gênero. Batizado de $4 \times 4$, ele ajudou a formar os parâmetros posteriormente adotados e desenhado por Gui Mattos - arquiteto que não está no rol da arquitetônica local, mas é amigo do empreendedor de longa data. Posteriormente, Zarvos passou a seguir preceitos semelhantes aos da empresa em que foi sócio de Cazarin. Reformatou sua imagem - com o auxílio dos mesmos publicitários - e criou em 2004, a Idea!Zarvos.

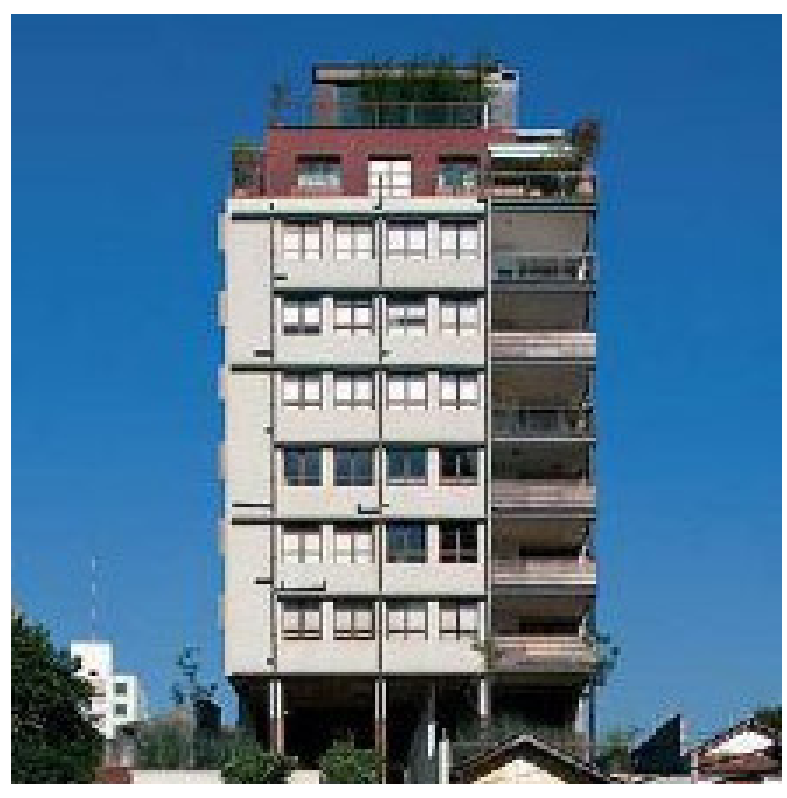

Figura 55 - Edifício 4 X 4 - São Paulo 2008, Gui Mattos 
Além de incorporadora é considerada pela equipe de Otávio Zarvos como sendo uma agência de idéias que reúne e gerencia parceiros com um objetivo comum: contribuir para a melhora da paisagem urbana da cidade, implantando edifícios que representem uma arquitetura contemporânea e de repertório inserida de modo a valorizar e respeitar a essência do bairro, a rua, o lote, o homem. Para Zarvos, numa cidade caótica como São Paulo, não se pode mais acreditar que tudo é permitido. O caos está limitando cada vez mais as possibilidades de ocupação urbana.

A estratégia inicial da empresa se manteve em buscar terrenos pequenos de menor valor para a construção de edifícios que se encaixassem na infra-estrutura local. A implantação desses edifícios também procurou impactar positivamente o entorno, favorecendo recuos que aumentem a distância de construções vizinhas e também utilizar parte dos terrenos para a criação de espaços abertos à vizinhança. O estudo de viabilidade e vocação do terreno adquirido é o primeiro passo do trabalho a ser desenvolvido no lote pela Zarvos.

Outra preocupação da incorporadora é garantir a busca e economia de recursos naturais como a construção seca, baixo gabarito de altura, grandes vãos de iluminação e ventilação nos apartamentos, recursos de autossuficiência nos edifícios como a reutilização da água da chuva, etc.

Para a Idea!Zarvos, o imóvel precisa se adaptar a vida de seu usuário, independente de quem seja. Daí o uso do conceito inicial de plantas $100 \%$ flexíveis que podem ser customizadas e adaptadas à rotina do morador. A estrutura e as instalações elétricas e hidráulicas são projetadas para possibilitar 
modificações no número e na localização dos ambientes, incluindo banheiros e cozinhas. A padronização das dimensões dos caixilhos também garante esta flexibilidade.

A Idea!Zarvos é divida em 04 departamentos:

Otávio Zarvos, fundador da empresa e no mercado de incorporação há mais de 15 anos. Trabalha na conceituação e coordenação geral de todos os projetos.

O departamento de incorporação é coordenado por arquitetos que conhecem profundamente a legislação urbana de São Paulo e são responsáveis por tornar economicamente viáveis todos os nossos empreendimentos. Estudam os terrenos e procuram locais da cidade para implantar os empreendimentos únicos realizados pela incorporadora. Participam também da fase inicial do desenvolvimento dos projetos feitos pelos diferentes arquitetos contratados pela empresa.

Há também a equipe de marketing e vendas que é formada por arquitetos e designers de interiores. São eles os responsáveis pela comunicação da Idea!Zarvos e pelo atendimento ao cliente.

A equipe de projetos e obras é o grupo de arquitetos e engenheiros que acompanha todo o detalhamento dos projetos dos empreendimentos e da personalização das unidades. Também materializam todo o trabalho desenvolvido, contratando e fiscalizando as empresas que constroem os prédios. 
Por fim, a equipe administrativo-financeira, onde engenheiros, administradores e advogados controlam todas as receitas, despesas e contratos da empresa, além de produzirem relatórios para investidores de cada empreendimento.

Segundo Zarvos, o ritmo ideal para o jovem empreendedor, que tem grande estoque de terrenos na região, é lançar um prédio a cada três meses. Em média, os projetos demoram um ano e a obra é finalizada 30 meses depois do início do projeto.

Anterior ao trabalho de Zarvos, um dos primeiros empreendimentos desse tipo em São Paulo foi o Loft Pinheiros, da Brookfield: $100 \mathrm{~m}^{2}$, dois quartos-suíte, projeto de Botti Rubin em 1986. Prosseguem a marca de expressão construtiva da dupla, característica dos seus residenciais dos anos de 1960, com estrutura de pilares e vigas aparentes e fechamentos de alvenaria, como nos Gemini, projeto de Eduardo de Almeida para Formaespaço exemplificado em capítulo anterior desta pesquisa. O empreendimento parece não ter tido seguidores imediatos, mas cerca de dez anos depois tem início uma acentuada expansão imobiliária desse produto. 
A onda imobiliária que se formou em meados dos anos 90 foi exemplificada no jornal A Folha de $S$. Paulo com a noticia dia 11 de maio de 1997 que o setor "dá sinais de que descobriu o cliente que prefere espaço interno amplo e pé-direito alto a vagas na garagem ou playground". Em 1999, é lançado pela Stan o Loft São Paulo I, projeto de João Armentano. Daí em diante, os lançamentos proliferam.

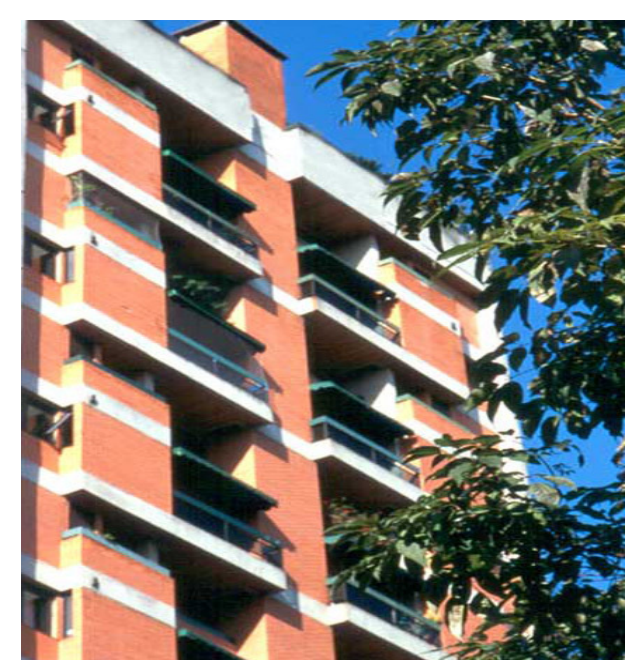

Figura 56 - Edifício Loft Pinheiros - São Paulo 1986, Botti Rubin

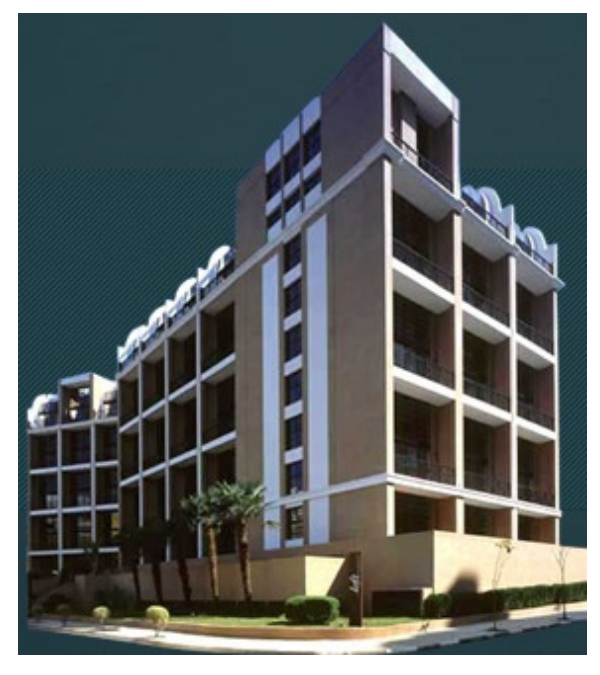

Figura 57 - Ed. Loft São Paulo I 1999, João Armentano

A incorporadora Stan, entre 1997 e 2000, lançou quatro condomínios na Linha Loft São Paulo, seguida pela linha Grand Loft, cujo segundo condomínio foi concluído em 2009, todos com projeto do arquiteto João Armentano. Situam-se na mesma faixa de área, mas são condomínios de maior porte, com ênfase 
na variedade de equipamentos de lazer de uso comum, e com outra identidade arquitetônica, comum a todos.

Além dos já citados edifícios da Movimento Um, dentro do período de tempo determinado para esta pesquisa, os prédios residenciais já concluídos pela Idea!Zarvos são: Fidalga 772 de Andrade e Morettin e Ourânia de Gui Mattos, ambos na Vila Madalena. Em construção temos: Edifício Itacolomi do Grupo SP e o edifício $360^{\circ}$ do arquiteto Isay Weinfeld.

Weinfeld destoa um pouco dos demais escritórios escolhidos: é o arquiteto de maior renome e também o que cobra honorários bem mais elevados. Inicialmente para os incorporadores, ele desenvolveu uma vila de casas, que não foi adiante. O edifício $360^{\circ}$ é o grande destaque da produção de Zarvos que comprou um terreno na zona oeste, mas um pouco fora do eixo da Vila Madalena, instigado pelo preço e pela possibilidade de vista panorâmica. Não poderia errar: teria que contratar um arquiteto acima de qualquer suspeita. Isay Weinfeld foi o nome. Por causa do porte, ele contatou outras incorporadoras: ficou com $15 \%$ do negócio e vendeu o resto. O projeto do edifício $360^{\circ}$, parte de uma estrutura regular que apoia as muitas lajes. Dentro de cada andar, apartamentos-contêineres de tamanhos diferentes são intercalados por varandas no limite da planta regular. Inscrito no prêmio Future Projects Award, da revista inglesa Architectural Review, o projeto ganhou na categoria residencial. A mídia paulistana ficou de olhos cheios e se da lógica do mercado imobiliário paulistano, que, de um lado, é bastante apressou a divulgar o feito. 
De fato, o prédio será capaz de mudar, mesmo que em uma pequena parte, um pouco profissional em relação ao produto que desenvolve, mas, de outro, é muito tacanho com a cidade e sua arquitetura.

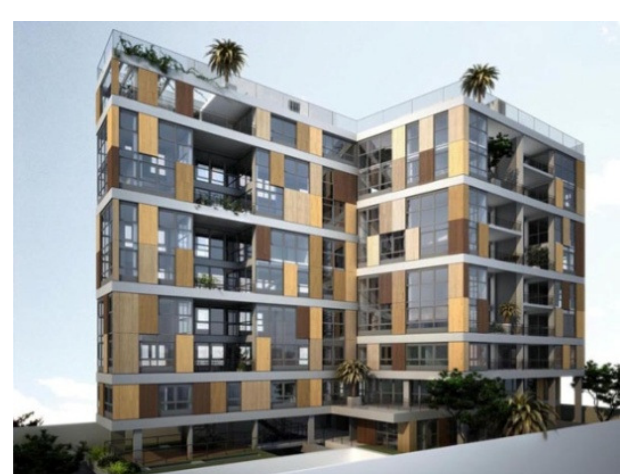

Figura 58 - Edifício Fidalga 772 - São Paulo 2011, Andrade Morettin

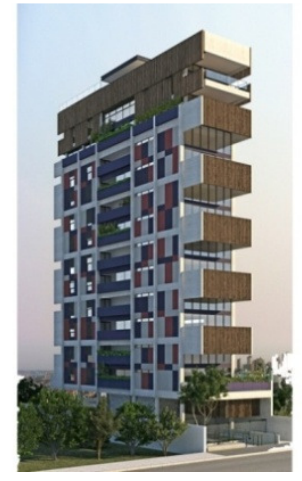

Figura 60 - Edifício Itacolomi 445 - São Paulo Projeto 2008/2009 - em obras, Grupo SP

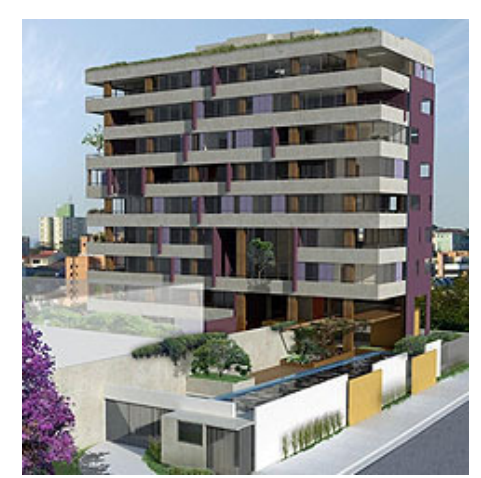

Figura 59 - Edifício Ourânia 77 - São Paulo 2011, Gui Mattos

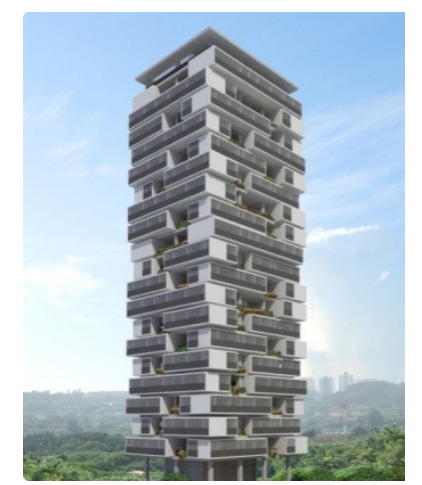

Figura 61 - Edifício $360^{\circ}$ - São Paulo Projeto 2008/2009 - em obras, Isay Weinfeld 
Nesse ínterim, outros produtos diferentes foram lançados pelo mercado imobiliário, no sentido de mostrar novidades de interesse arquitetônico. Por enquanto, além de Zarvos que anuncia sua diferenciação do mercado, com alto impacto estético e acentuada valorização autoral, quem mais se destacou foi a MaxHaus, proposta lançada por José Paim de Andrade, ex - executivo da construtora Rossi e baseada em três pilares: campanha de mídia forte, ênfase em arquitetura de interiores e recursos externos de banco de investimentos norte-americano. Com a quebra do sistema financeiro internacional, as ambições foram revistas e o que sobrou para o público foi a noção de flexibilidade dos espaços internos. A idéia parece fazer sentido: apesar da Movimento Um já ser extinta, Zarvos acredita que os clientes percebem muito mais facilmente a compra no espaço interno. Em outras palavras, não possuem a real percepção da arquitetura que estão adquirindo. De qualquer forma acredita que as pessoas vão perceber que moram em um Andrade Morettin, Grupo SP e Triptyque daqui a dez anos.

Zarvos já participava do nascente ciclo dos lofts e apartamentos diferenciados. Em 1999, lançou três condomínios de lofts na Vila Madalena, entre $120 \mathrm{~m}^{2}$ e $200 \mathrm{~m}^{2}$. Entre 1995 e 2006, Zarvos participa da concepção, incorporação e construção, com outros associados, de empreendimentos projetados por Luiz Fernando Rocco e Fernando Vidal, como o Mada Loft, de dois quartos e $160 \mathrm{~m}^{2}$ [1996/1999], o Roof Vila Madalena, de dois quartos e $94 \mathrm{~m}^{2}$ ou $121 \mathrm{~m}^{2}$ [2003/2005], ou o Art House, de um quarto e $86 \mathrm{~m}^{2}$ [2004/2006]. Todos possuem semelhanças nos esquemas de organização espacial, característicos do arquiteto, com espaços comuns amplos, deslocamentos sutis de volumes e planos, destacando varandas e empenas suavemente coloridas, e caráter plástico de leveza e clareza. 


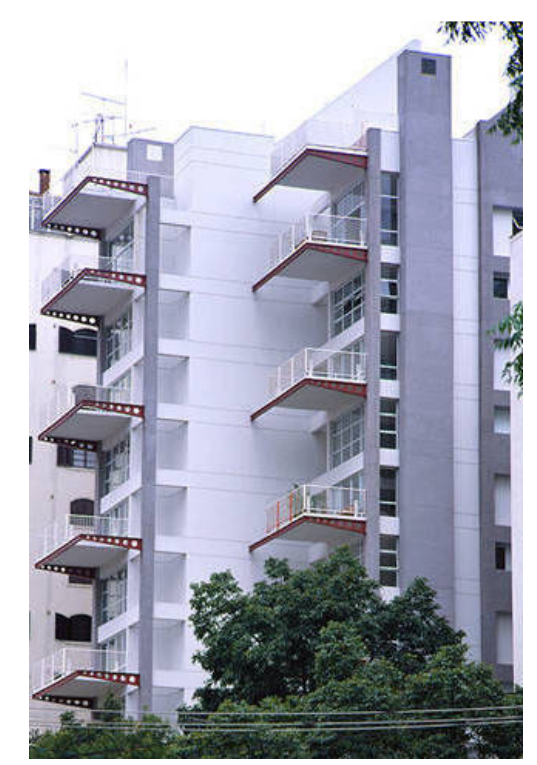

Figura 62 - Edifício Mada Loft 1999, Rocco e Vidal

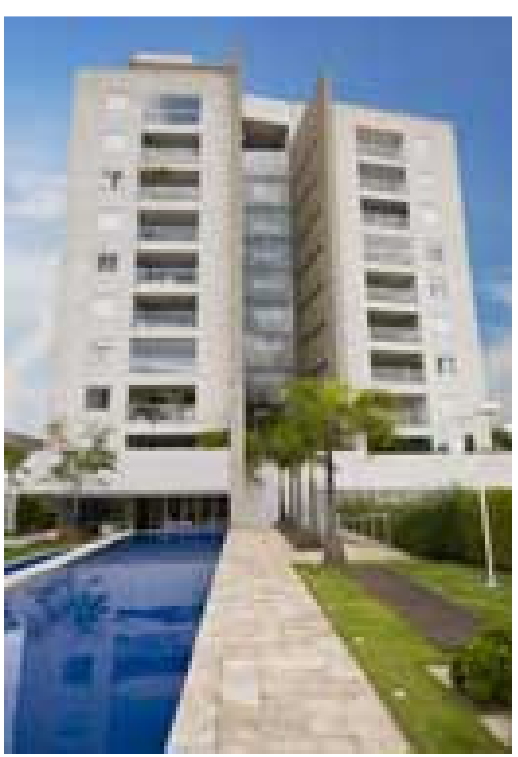

Figura 63 - Edifício Roof Madalen 2005, Rocco e Vidal

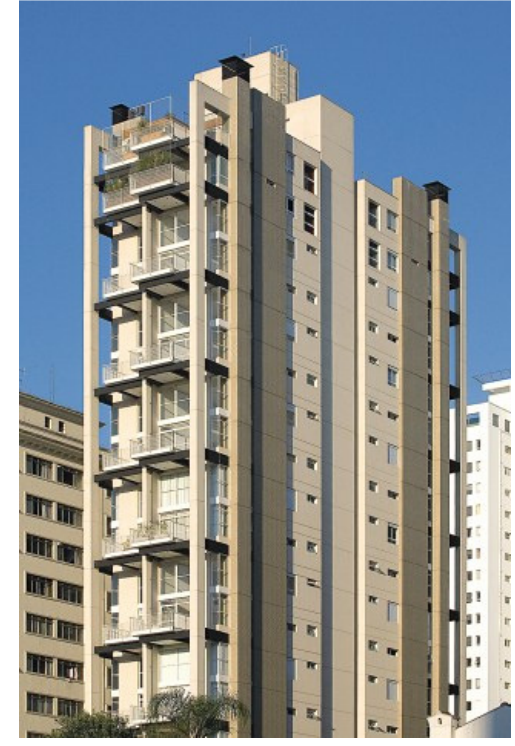

Figura 64 - Ed. Art House 2006, Rocco e Vidal

Posteriormente, com estratégias e bons resultados semelhantes, Rocco e Vidal projetam para a Stan os edifícios da linha Arte Arquitetura, de amplos espaços internos comuns com obras de arte - como no Spazio 2222, de Decio Tozzi [1996] -, com apartamentos-tipos de dois quartos entre $78 \mathrm{~m}^{2}$ e $110 \mathrm{~m}^{2}$; três quartos entre $108 \mathrm{~m}^{2}$ e $169 \mathrm{~m}^{2}$, concluídos entre 2008 e 2009. 

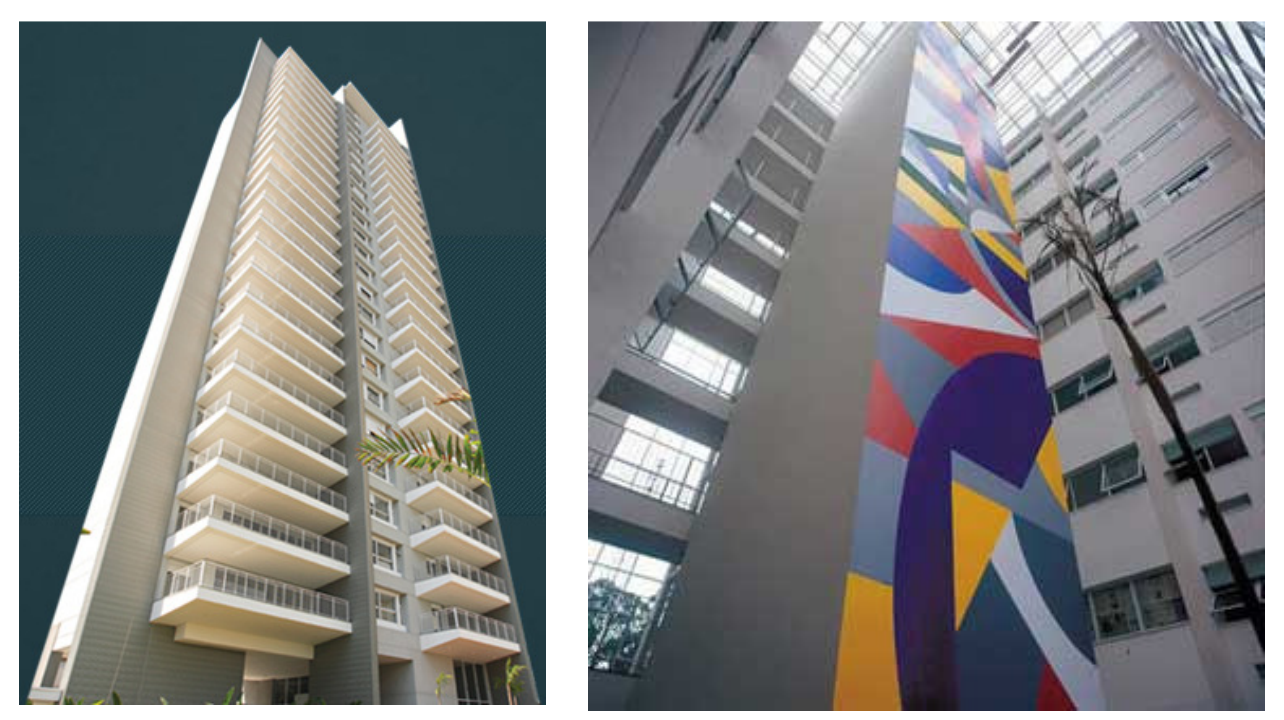

Figura 65 - Edifício Arte Arquitetura Itaim 2007 - Rocco e Vidal

Figura 66 - Edifício Spazio 2222 1996 - Décio Tozzi

O objetivo é caracterizar produtos diferenciados em relação a outros de faixa de áreas e valor semelhante. Nesse processo, Zarvos formulou um conceito de produto, elaborado pela contribuição de talentos diversos, que a cada experiência se renova pela reflexão dos resultados e abertura de novas possibilidades. É um produto imobiliário, mas também um produto cultural. A publicidade não se reduz à divulgação de um produto pronto, mas concorre na constituição de seu conteúdo, agregando-lhe valor simbólico, suportando ela própria ações artísticas. Mas, à medida que o processo criativo e econômico se desenvolve, há uma perda do choque do novo e uma estabilização de fórmulas, cuja solução impõe mais do novo, ou a expansão em novas regiões do segmento de mercado, o que parece 
indicar os novos lançamentos fora da região de Vila Madalena, concomitante ao crescimento do porte caso do $360^{\circ}$ de Isay Weinfeld, empreendido pela Idea!Zarvos e a Stan.

Tudo isso em um momento de alterações estilísticas das grandes empresas de produtos de alto valor dentro do mercado imobiliário e de seus tradicionais e sempre presentes arquitetos; existe a hipótese de que agora, a onda do estilo contemporâneo substitui a do neoclássico.

Para Zarvos quem constrói a cidade são os incorporadores e não o Estado. Uma solução dita por ele em entrevista à Revista $A U^{45}$ seriam os arquitetos virarem incorporadores, embora acredite que os profissionais não estejam preparados para isso. Para Zarvos, a iniciativa de regenerar a paisagem urbana de São Paulo nunca virá das incorporadoras. Se o arquiteto comprar um terreno e decidir construir um prédio, vai ser muito melhor do que a média. Se será bem-sucedido, talvez. Seria preciso ver as outras disciplinas envolvidas, não apenas o projeto.

${ }^{45}$ Revista AU. Ano 26 n.207 - Junho 2011. Entrevista com Otávio Zarvos por Cleide Floresta. P. 66 - 68.

${ }^{5}$ Revista AU. Ano 26 n.207 - Junho 2011. Interseção Especial - “O empresário criativo e a arquitetura equilibrista” por Luiz Mauro do Carmo Passos. P. 69 - 71. 


\section{ALÉM DE SÃO PAULO}

Em Porto Alegre, a Smart! apresenta-se como uma incorporadora-butique, em um edifício inicial com perfil semelhante aos concebidos por Zarvos, do porte à comunicação publicitária.

Entretanto, o Montevidéu, do escritório Vazio S/A, em Belo Horizonte, tem em comum aos exemplos citados apenas a característica de se apresentar como diferente ao convencional - mas de outra maneira. Não seria correto chamar o arquiteto Carlos Teixeira, do Vazio S/A, de incorporador, no sentido que foi Franz Heep, por exemplo. Teixeira entrou no negócio por "certa insatisfação com o mercado imobiliário e má remuneração da arquitetura". A incorporação integra e financia o trabalho de produção artística de outros projetos não tão lucrativos do seu estúdio.

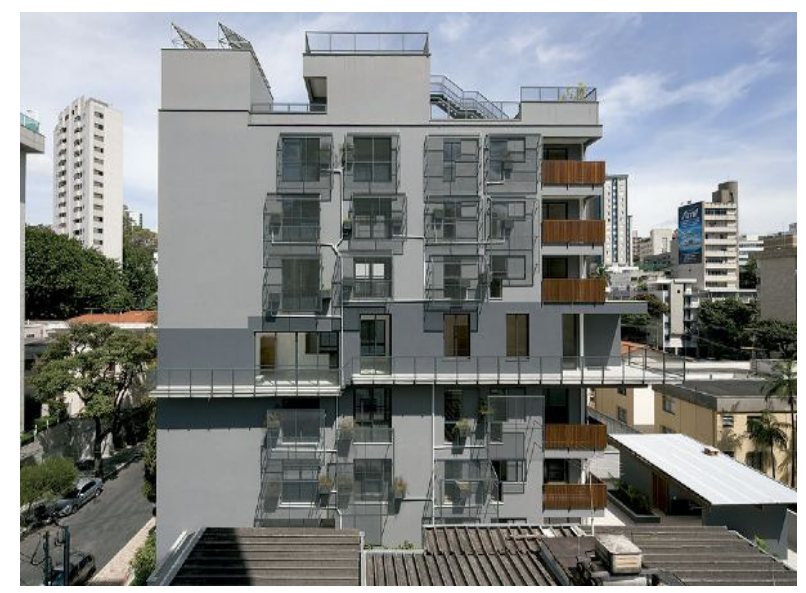

Figura 67 - Edifício Montevidéu, Belo Horizonte $2011-$ Vazio S/A

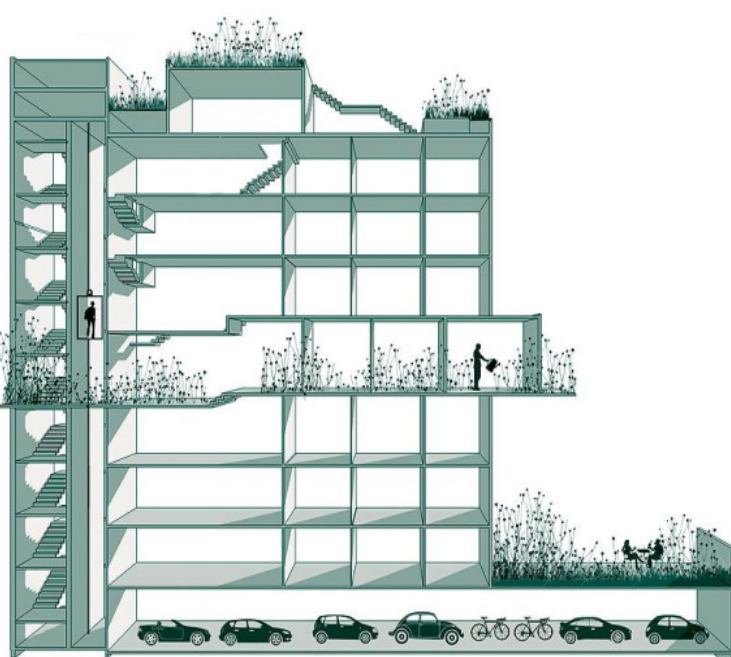

Figura 68 - Edifício Montevidéu, Belo Horizonte 2011 - Vazio S/A 
Num primeiro olhar, o Montevidéu exibe elementos incomuns, mas é uma planta racional, apta a diversos tipos de famílias. O conceito aplicado é o de adaptabilidade, não de flexibilidade. Há um térreo com garagem e oito unidades. A área é a média da faixa referencial de $65 \mathrm{~m}^{2}$ a $130 \mathrm{~m}^{2}$. As plantas são basicamente iguais, o mesmo tipo arquitetônico. Áreas molháveis concentradas, dispostas a oeste; sala e quartos a leste. A cozinha aberta pode ser fechada; a compartimentação de quartos e corredor, desfeita, estendendo a sala em um único espaço aberto.

Variações sutis produzem em cada andar acidentes que especificam cada moradia - parecidas, mas não exatamente iguais, como figuras de jogo de erros. A novidade está na região intermediária: no 501, pédireito de 3,50 m, sala com desnível e terraço ao longo da face leste e norte efetuam uma intervenção no que poderia ser um prédio comum. Esse acidente repercute no pé-direito de partes dos 401 e 601 , com desníveis na sala. A geometria pura do volume é proporcionalmente corrompida por estas singularidades e pelo experimental filtro solar de tela.

Finalmente, e mais importante, um requisito essencial: janelas de todos os quartos e salas voltados para o sol da manhã, ventilação cruzada em todas as unidades. Para PASSOS, nem mais nem menos. Nada demais. Estética nem minimalista, nem maximalista [algo entre Loos e Gehry] equilibrismo. Igualdade e diversidade foram possíveis neste caso e que venham outros mais. 


\subsection{IDEA! ZARVOS E 0 \\ ESCRITÓRIO \\ ANDRADE MORETTIN}

Vinicius Andrade e Marcelo Morettin foram apresentados a Otávio Zarvos através de um cliente comum. Em 2005, surge o primeiro projeto para um edifício da Movimento Um, o Aimberê 1749. Desde então, o escritório mantém uma constante parceria de projetos e obras com a Idea!Zarvos. O escritório paulista Andrade e Morettin foi fundado há pouco mais de quinze anos, após o primeiro certame dos arquitetos ao vencer o plano diretor para a Faculdade de Medicina da Universidade de São Paulo. Atualmente conta com oito profissionais, sendo três deles, coordenadores. Ambos graduaram-se pela FAU USP, sendo Morettin em 1991 e Andrade em 1992. A sociedade causou surpresa dos demais ex - colegas de faculdade, pois era notável a diferença de personalidade de ambos: Morettin calado, sério e reservado. Andrade, falante e expansivo. Enfim, as afinidades aconteceram na biblioteca da escola, aonde buscavam as novidades da arquitetura contemporânea nas revistas estrangeiras, principalmente as do arquiteto holandês Rem Koolhaas. Ambos afirmam que a obra de Koolhaas os aproximou ainda mais, contribuindo para organizar e alinhar a maneira da dupla fazer arquitetura. Para Vinícius Andrade, na época de sua formação ainda existia na FAU certo constrangimento em admitir referências internacionais. Morettin avalia:

Os projetos do Koolhaas possuem formas muito fortes, mas nada daquilo veio de gesto ou um traço. O que há por trás é uma idéia de transformação do lugar, do espaço, de manipulação do programa, de lidar com questões que vão além da construção. Ele pensa de maneira ampla, talvez pela própria formação. 
A dupla revela que tem habilidades complementares, sendo Andrade mais empírico e Morettin mais cerebral. Uma característica fundamental da obra do escritório é o uso intenso de materiais industrializados. Andrade relata que acreditam na utilização de componentes industriais em contraponto ao trabalho artesanal do canteiro de obras. Exemplos que reforçam este mote são os projetos Living Steel para um concurso de Habitação Social em Recife, Pernambuco [Figura 67] e o Centro de Informações do Comperj em Itaboraí, Rio de Janeiro [Figura 68]. A própria apresentação das propostas em diagramas [Figuras 69 e 70] reforçam a idéia do raciocínio de composição, demonstrado de forma esquemática, o encontro de materiais.

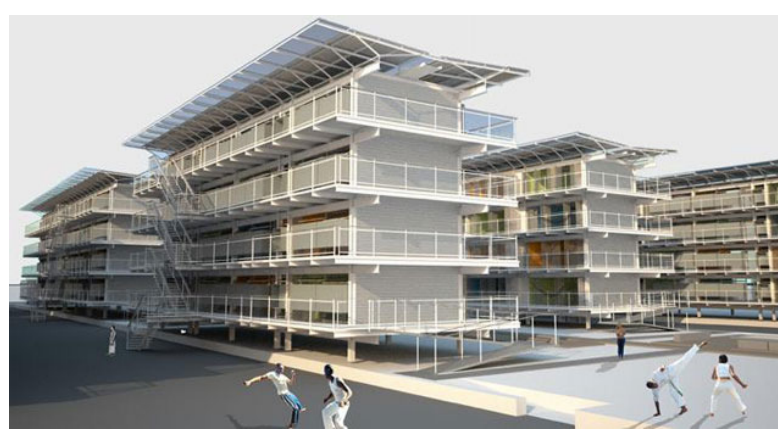

Figura 67 - Projeto ganhador do 20 Prêmio Living Steel para Habitação Popular em Aço. 2007 Andrade Morettin

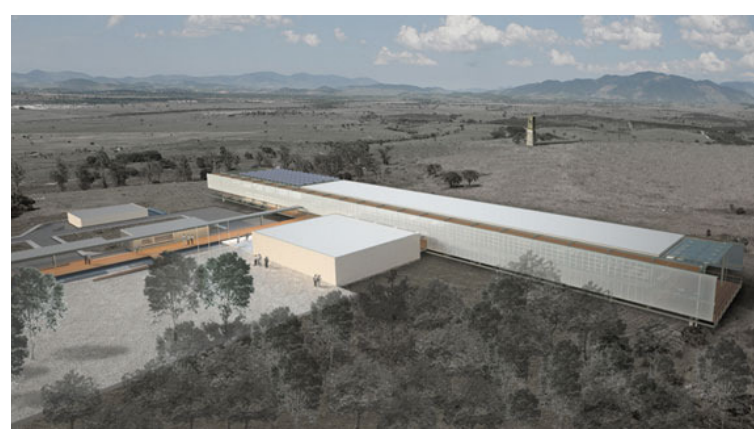

Figura 68 - Centro de Informações do Comperj. 2008 Andrade Morettin 

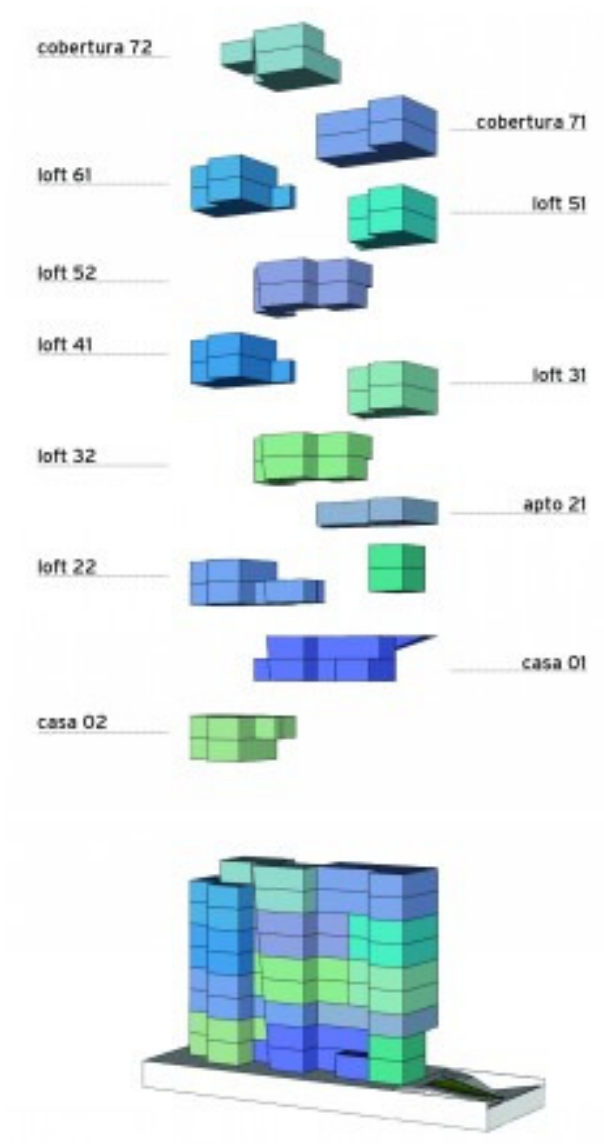

Figura 69 - Diagrama de composição - Ed. Aimberê1749. 2005 Andrade Morettin
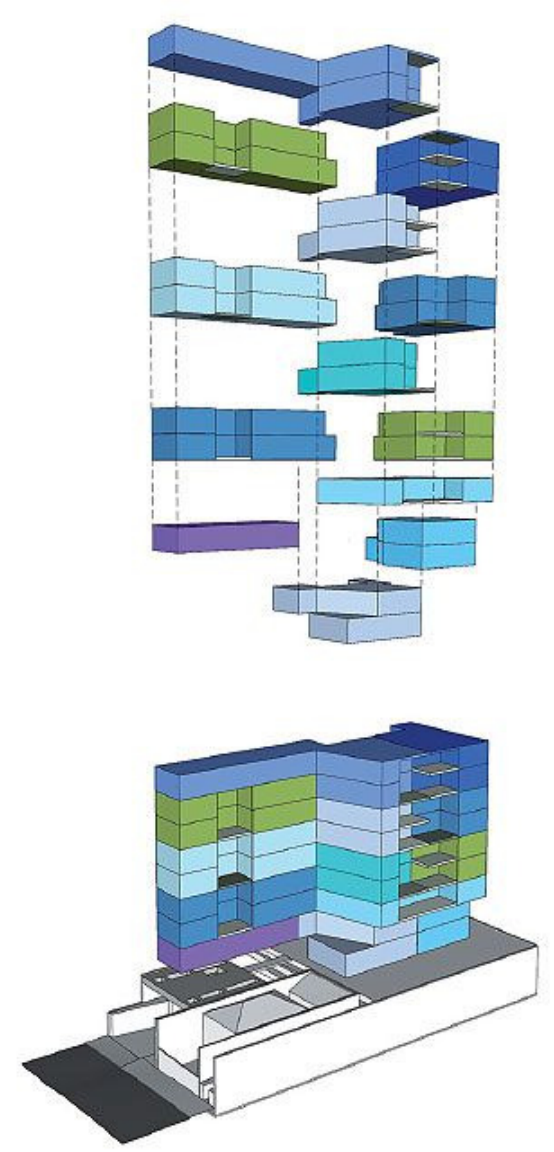

Figura 70 - Diagrama de composição - Ed. Fidalga 727. 2007, Andrade Morettin 


\section{EDIFÍCIO AIMBERÊ 1749}

O edifício Aimberê 1749, marca por seu pioneirismo. Foi a primeira encomenda do mercado imobiliário ao escritório Andrade Morettin e também, a primeira obra concluída da Movimento Um. O projeto data de 2005 e a conclusão de sua obra foi em 2008. Localizado no bairro de Perdizes, está em uma Zona Mista de Alta Densidade - ZM - 3a/07 [Figura 71]. 0 terreno mede $775,89 \mathrm{~m}^{2}$ e foram construídos $3.685 \mathrm{~m}^{2}$ distribuídos em 12 unidades residenciais que variam de $95 \mathrm{~m}^{2}$ a $215 \mathrm{~m}^{2}$. Sua configuração consiste em subsolo, térreo, 08 pavimentos e cobertura.

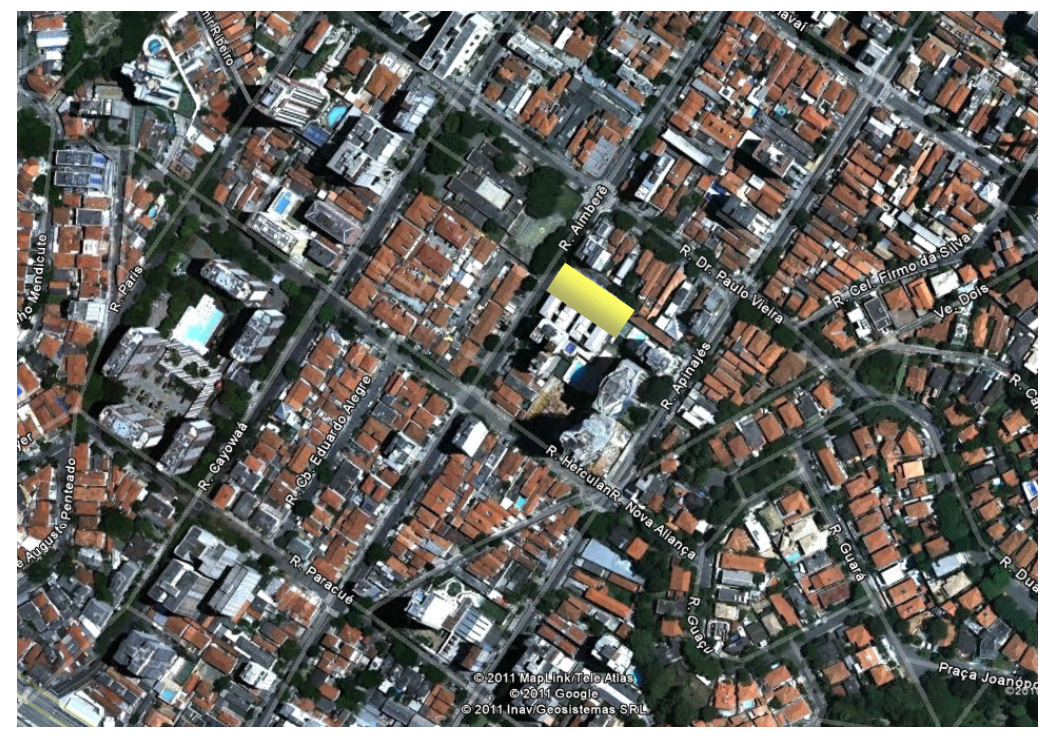

Figura 71 - Situação do edifício - Google Maps 2011 
O edifício é composto por um volume regular lapidado com cortes e aberturas que refletem a diversidade de unidades. Foram excluídos do programa os ambientes comuns aos condôminos vendidos como comodidades - salão de festas, playground, sala de ginástica, etc. Isso não só por uma questão de espaço e ocupação, já que o terreno possui uma área restrita $775 \mathrm{~m}^{2}$ [15mx50m], mas também por se tratar de uma região farta de equipamentos urbanos, de comércio e serviços que fazem da cidade, segundo o arquiteto Vinicius Andrade, o espaço coletivo do prédio, com suas praças e eventos. O gabarito do edifício não agride a paisagem ao redor; foi preocupação dos arquitetos a inserção delicada do edifício laminar na quadra que ainda conta um generoso recuo frontal junto à rua, ocupado por um jardim e rampa de acesso ao hall. Para os arquitetos, um respiro tanto para que está na rua, como para quem acessa o prédio. Para a marcação da entrada ao edifício, os autores a definiram com planos inclinados que conformam o jardim e a rampa de acesso ao hall. [Figuras 72, 73, 74, 75]. 


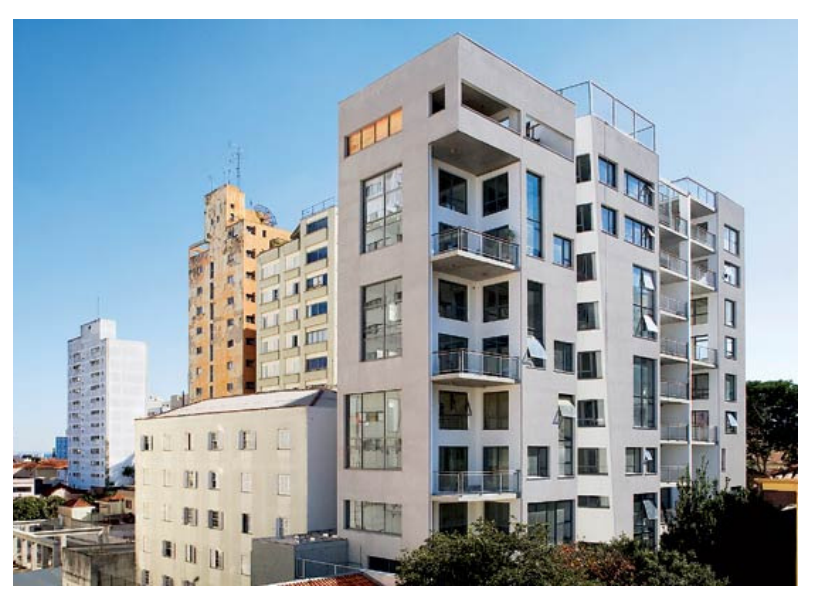

Figura 72 - Vista Sudeste, volumetria destacada no entorno convencional. Foto: Daniel Ducci

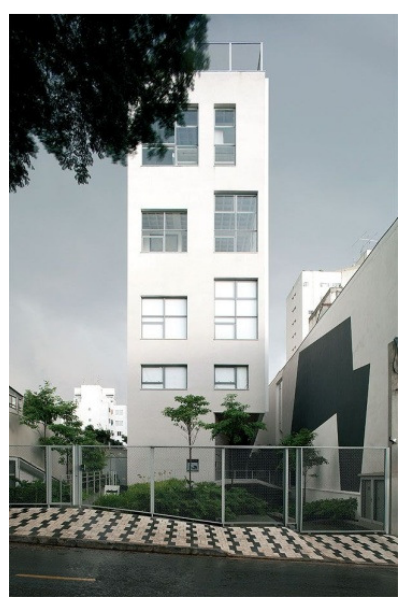

Figura 74 - Vista Norte, acesso ao edifício. Foto: Daniel Ducci

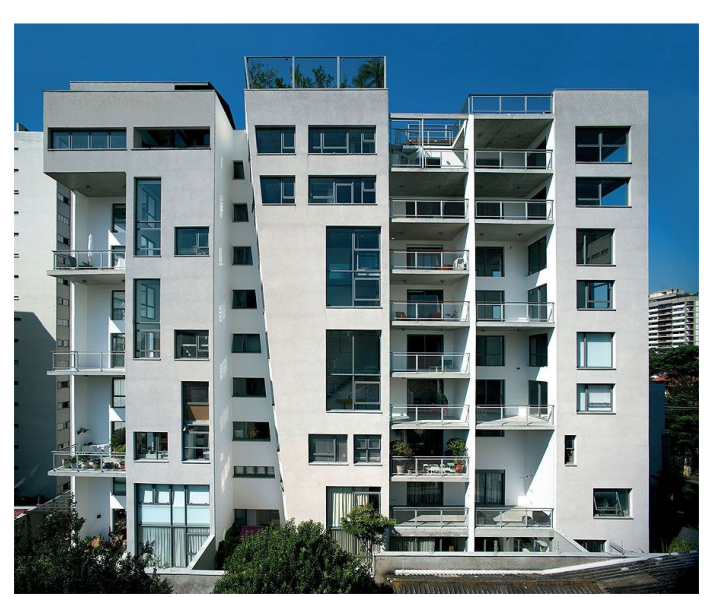

Figura 73 - Vista Leste, recorte na diagonal fragmenta volume. Foto: Daniel Ducci

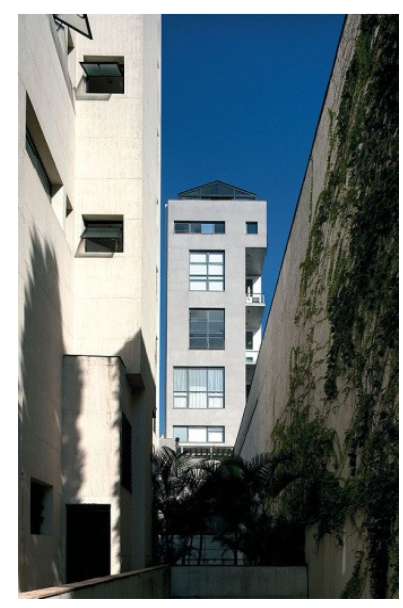

Figura 75 - Vista Sul Foto: Daniel Ducci 
Como uma ponte, eles passam sobre o acesso de veículos ao subsolo [Figuras76 e 77].

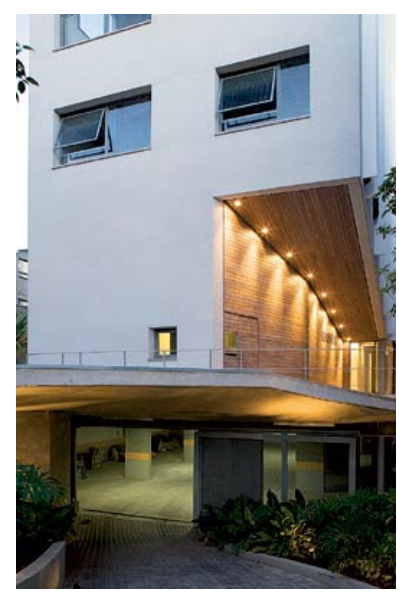

Figura 76 - Passarela para pedestres de acesso ao edifício Foto: Daniel Ducci

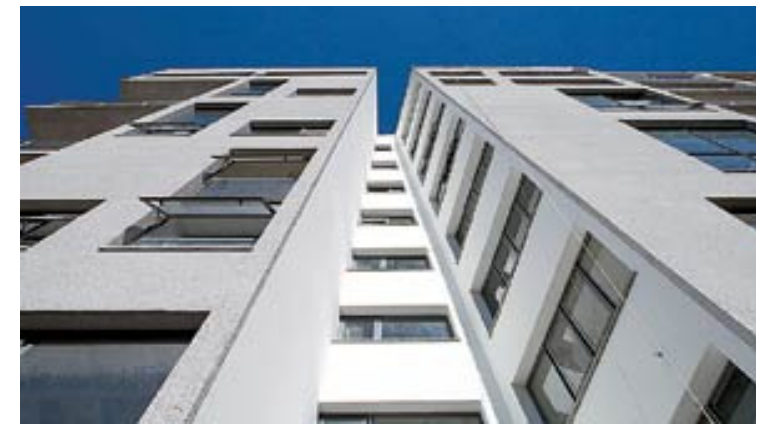

Figura 78 - Detalhe do recorte rompendo volume regular e facilitando a insolação. Foto: Daniel Ducci

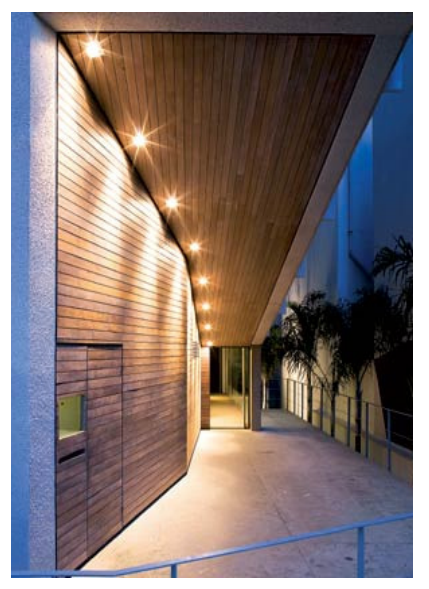

Figura 77 - Hall do edifício Foto: Daniel Ducci

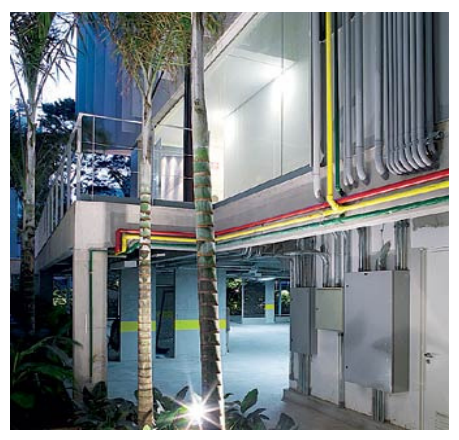

Figura 79 - Vista Oeste - detalhe das prumadas. Foto: Daniel Ducci 
Não existe uma planta-tipo. Como um jogo de tabuleiro, as unidades habitacionais são pedras soltas que se encaixam até montar todo conjunto. Tampouco há instalações hidráulicas fixas - as prumadas aparecem em número maior do que o normal em tubulações aparentes e coloridas na vertical do prédio, de tal sorte que os moradores podem instalar banheiros ou cozinha onde desejarem, flexibilidade útil para atender as necessidades de cada morador [Figuras 78 e 79 ]. Assim, o edifício de nove pavimentos é o resultado do encaixe de doze unidades autônomas, cada uma com sua morfologia específica. As áreas variam de $95 \mathrm{~m}^{2}$ a $215 \mathrm{~m}^{2}$. Morettin afirma que a idéia foi ofertar ao morador uma unidade básica de espaço e luz, pois nunca saberiam se determinado ambiente seria um quarto ou uma sala [Figuras 80 e 81]. Ainda acrescenta que, por esse motivo, fizeram algumas janelas fixas para entrada de luz e outras do tipo maxim-ar. Todas assimétricas. 


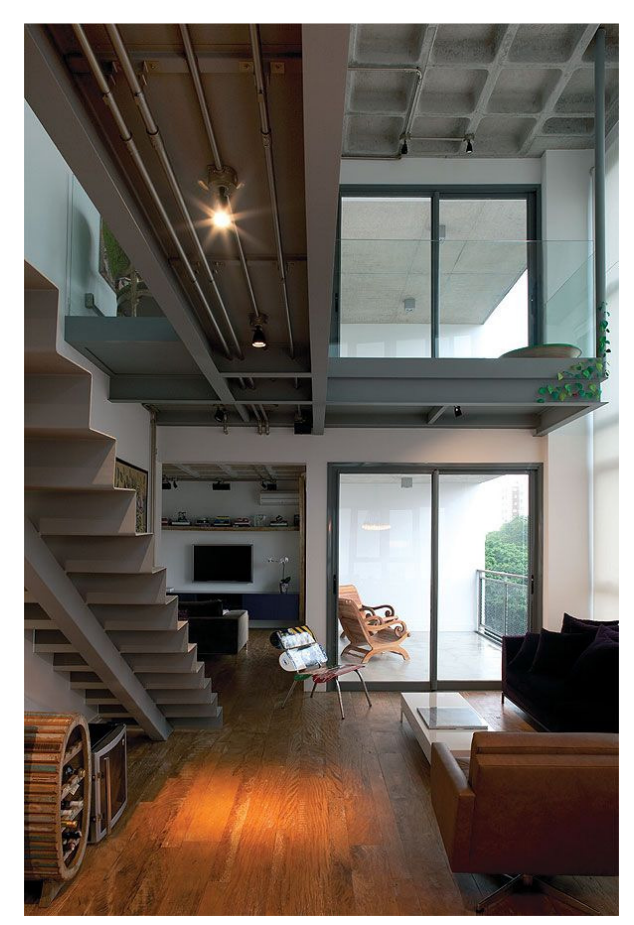

Figura 80 - Interior de apartamento. Foto: Marcelo Morettin
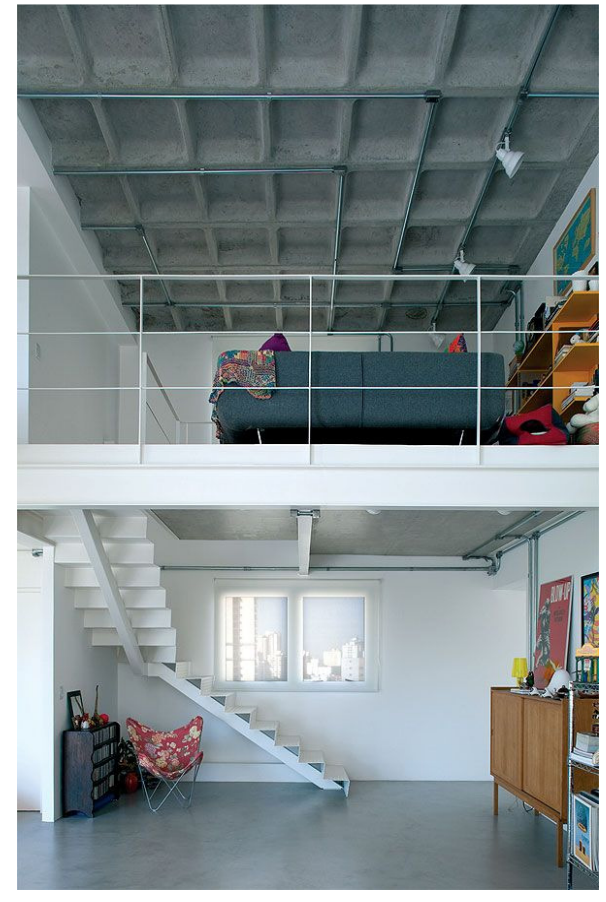

Figura 81 - Interior de apartamento Foto: Marcelo Morettin 
PROJETO EDIFÍCIO

AIMBERÊ 1749

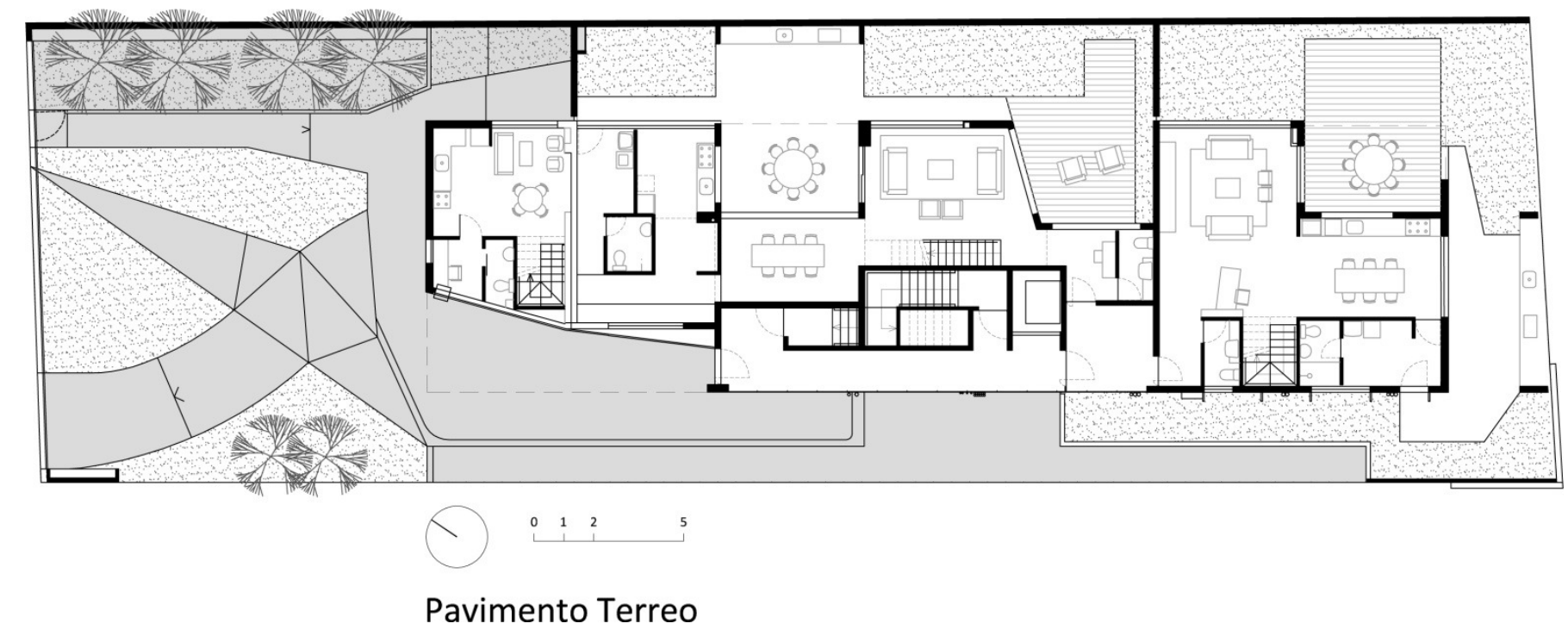




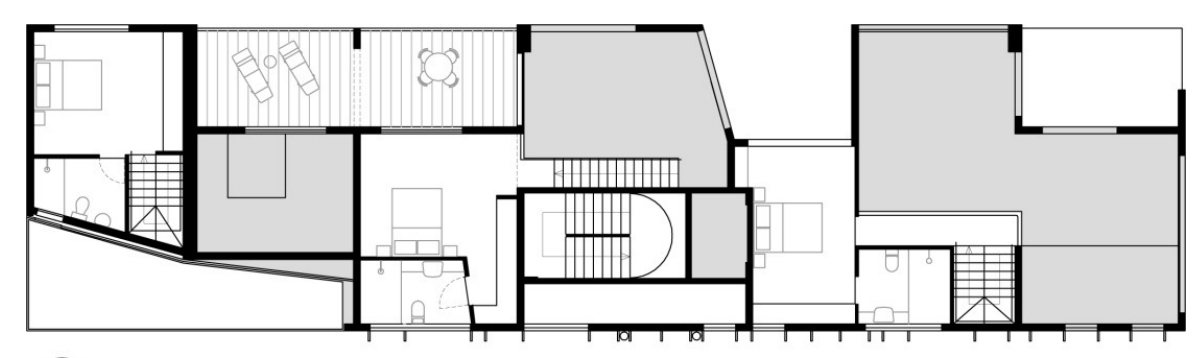

- $\begin{array}{llll}0 & 1 & 2 \\ 1 & 1 & 1\end{array}$

Planta 10 Pavimento

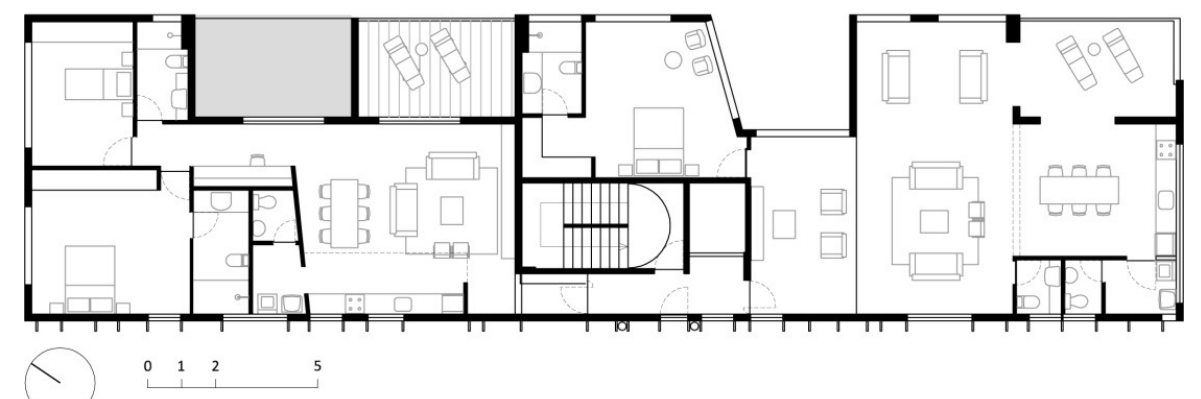

Planta 2ㅇ Pavimento 


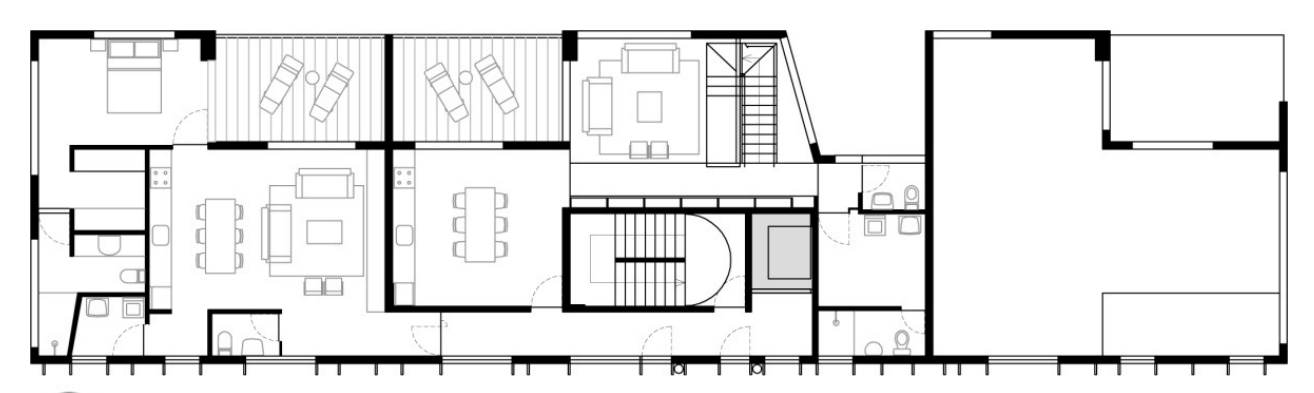

Planta 3ㅇ Pavimento

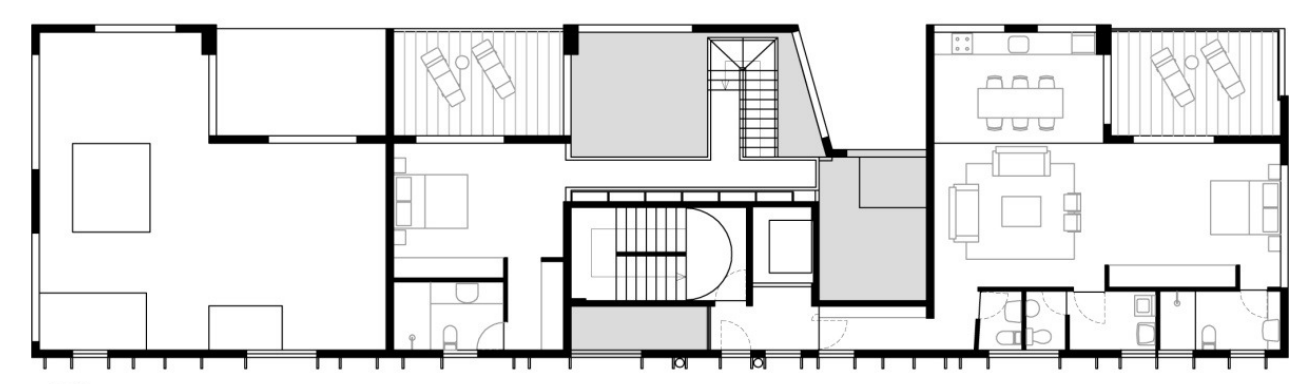

Planta 40 Pavimento 


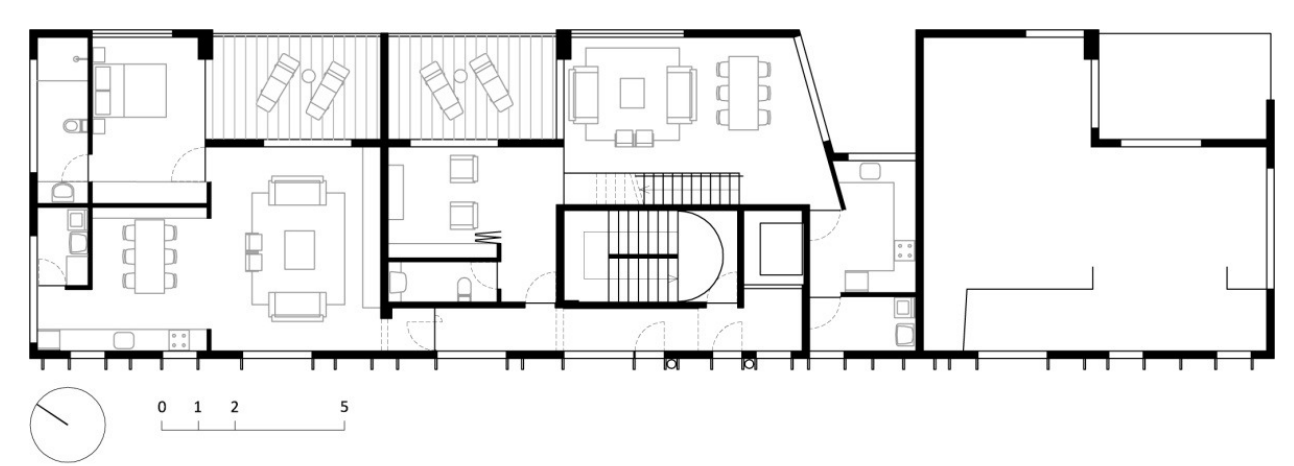

Planta 5o Pavimento

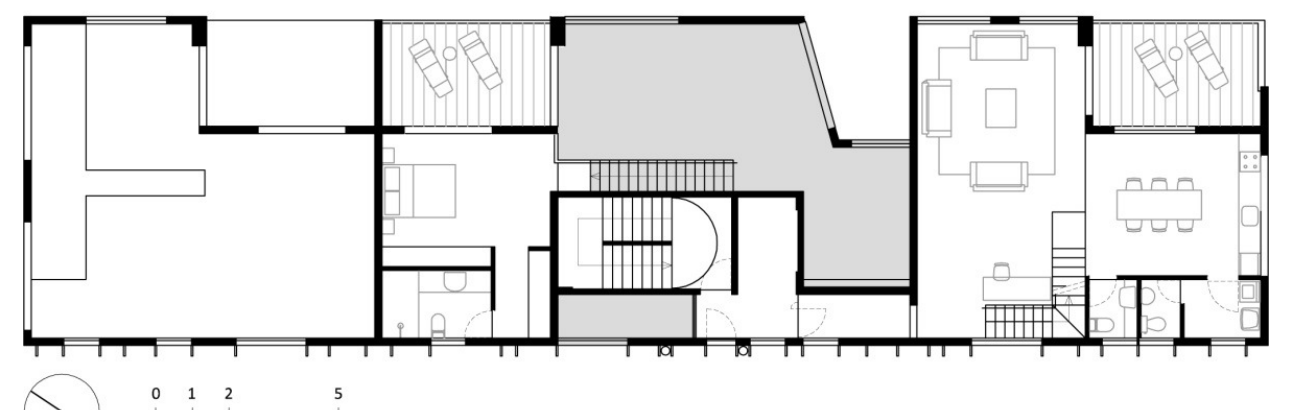

Planta 60 Pavimento 


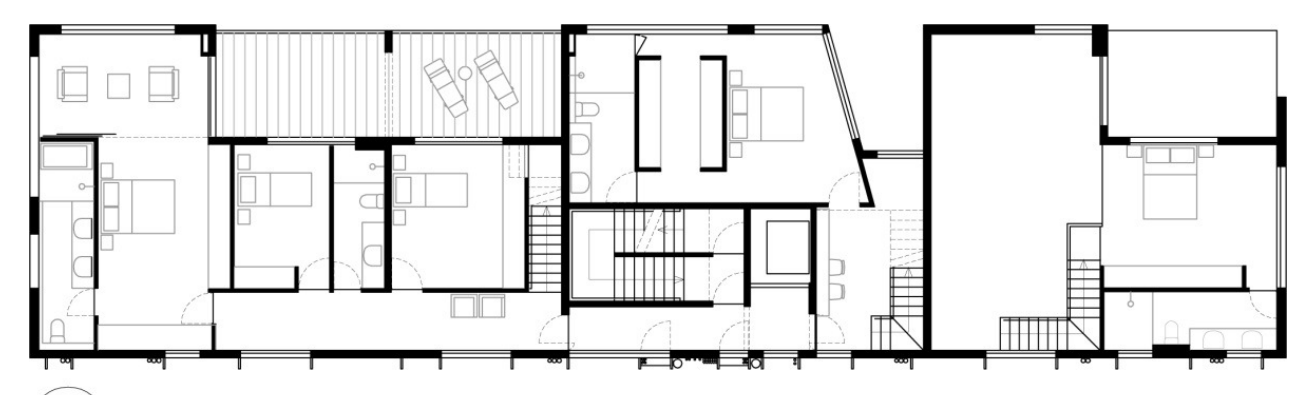

Planta 70 Pavimento

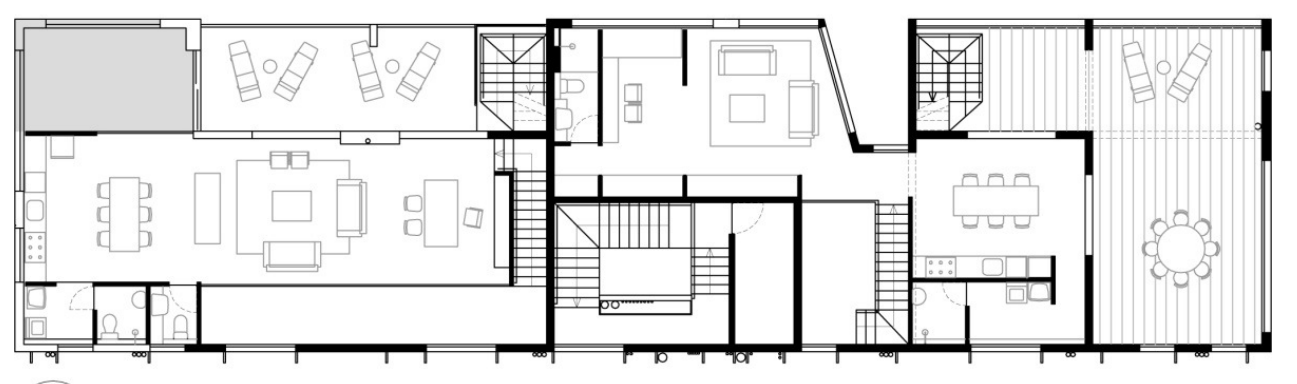

Planta 8o Pavimento 


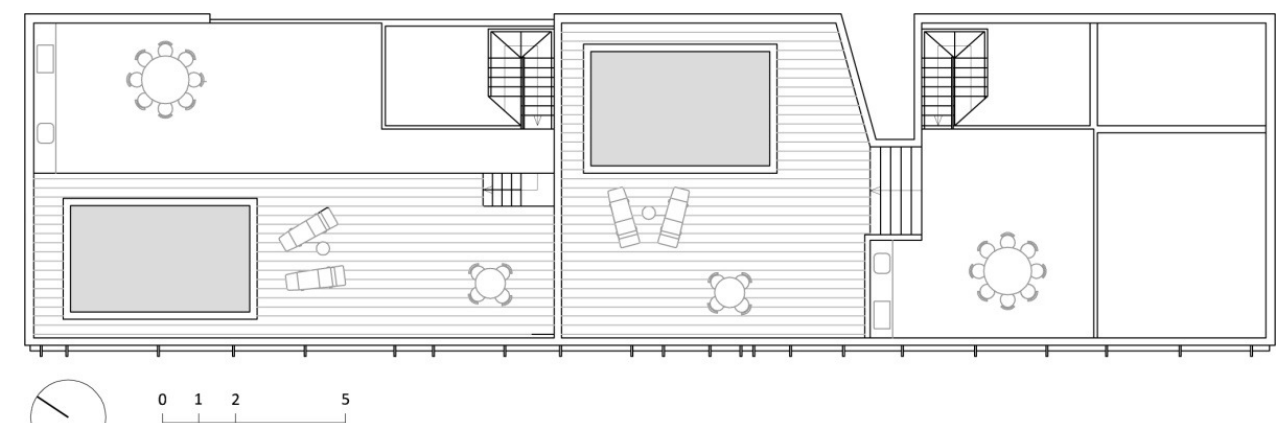

Planta 9o Pavimento 


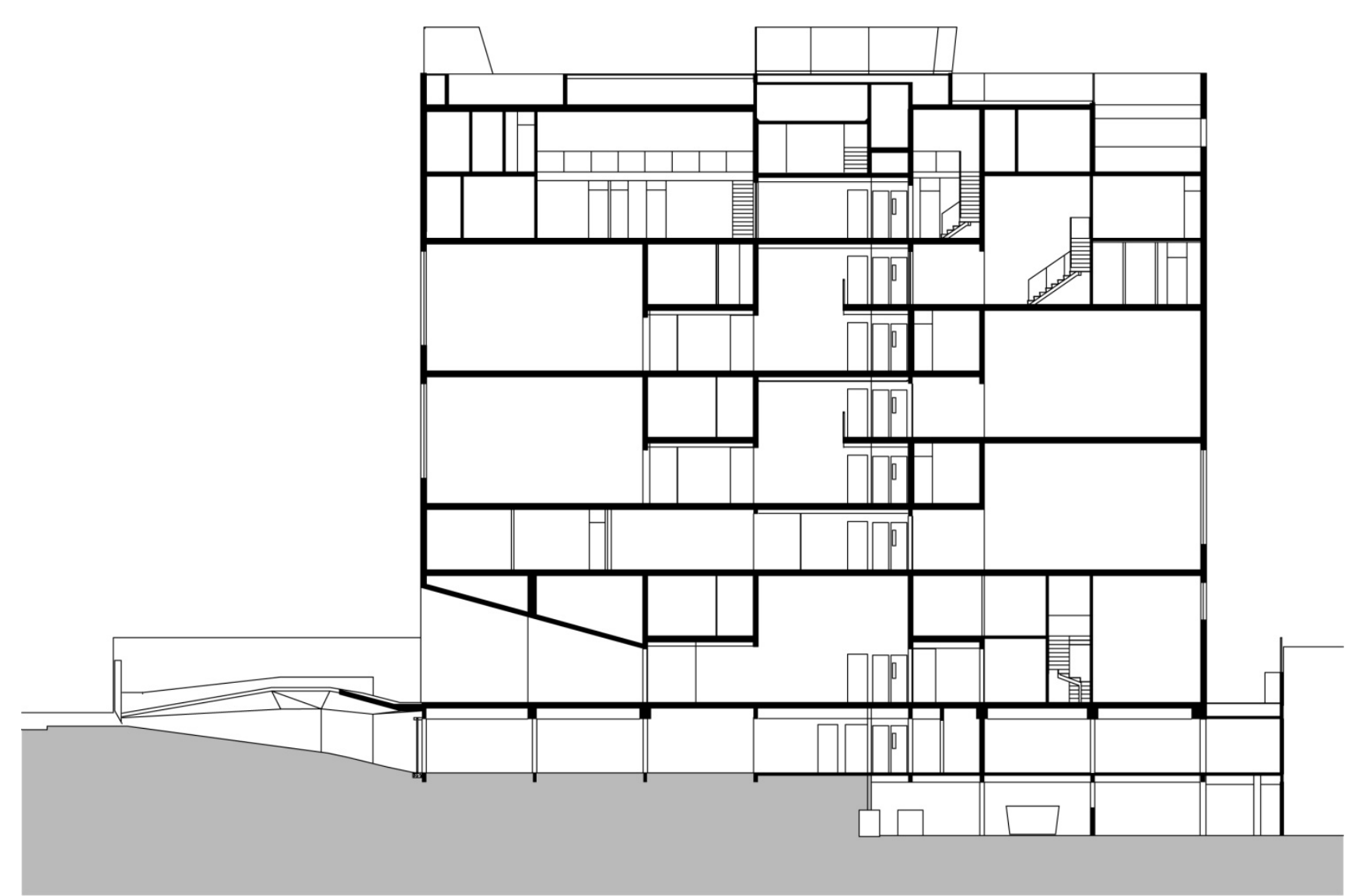

Corte Longitudinal 


\section{EDIFÍCIO FIDALGA 772}

O edifício Fidalga 772 foi o segundo trabalho do escritório Andrade Morettin para a Idea!Zarvos. Localizado na Rua Fidalga, no bairro da Vila Madalena, Zona Mista de Média Densidade - ZM 2/07. O edifício fica praticamente na frente de outra encomenda da incorporadora ao escritório Triptyque também analisado neste trabalho. O Fidalga 727, foi projetado em 2007 e sua obra concluída em 2011. Com terreno de $860 \mathrm{~m}^{2}$, possui $3.775 \mathrm{~m}^{2}$ de área construída, distribuídos em 12 unidades que variam entre $110 \mathrm{~m}^{2}$ e $220 \mathrm{~m}^{2}$ [Figura 82].

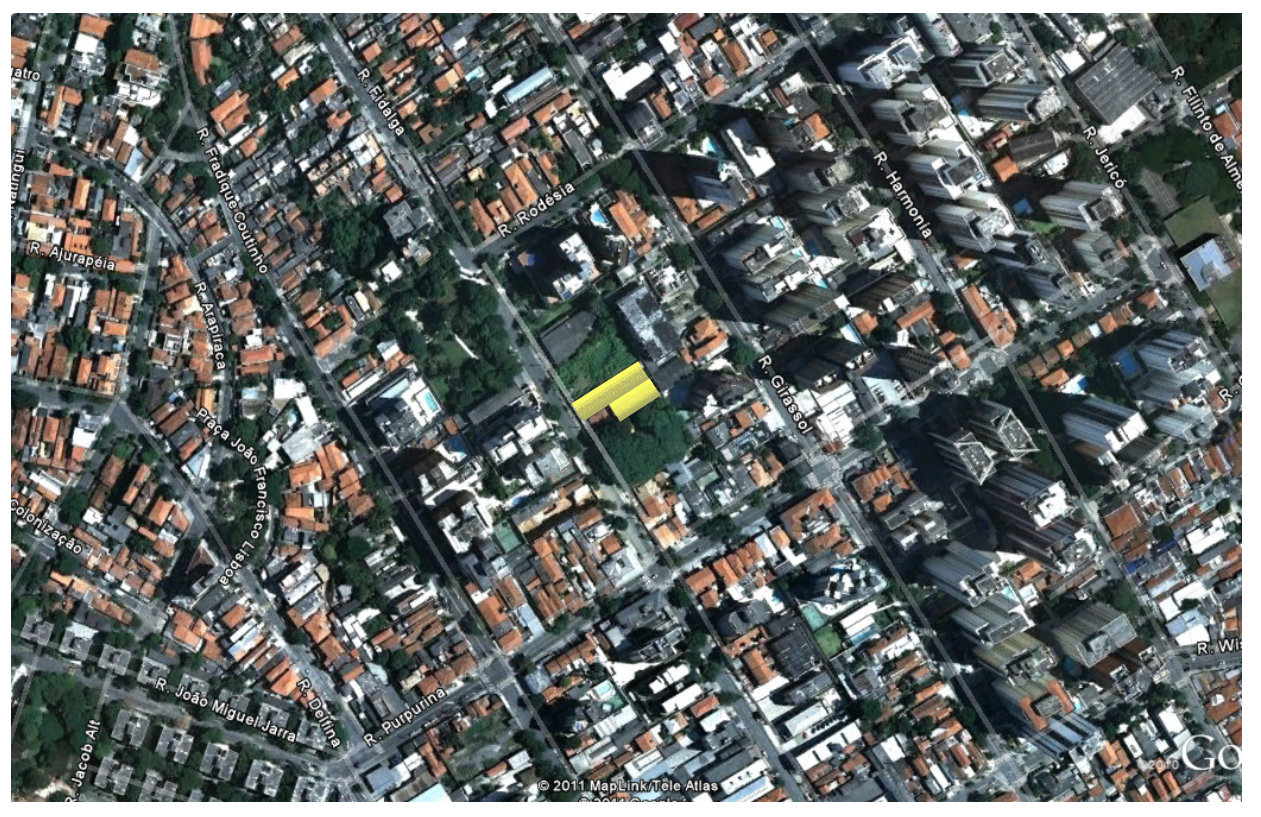

Figura 82 - Situação do edifício. Fonte Google Maps 2011 
A estrutura aparente das vigas de concreto desenha a fachada revelando os pavimentos e as diversas plantas das unidades do edifício. Unidos às vigas, os caixilhos de alumínio em toda a extensão exterior, ora são fechados por vidro, ora por painéis laminados para fachada, criando um ritmo de cheios, vazios e cores [Figuras83, 84 e 85].

Este projeto foi implantado a partir da junção pequenos lotes. Foi a impossibilidade da compra de um terreno - a moradora permanece no local - que levou à situação final do edifício: o formato em L. Segundo Vinicius Andrade, quando se tem o desafio de colocar uma construção grande dentro de um lote recortado, não há muitas opções. Os arquitetos optaram por uma suave inclinação no recorte do prédio para que o edifício tivesse uma certa fluidez na face principal. Não é, portanto, um L convencional. No lugar de um ângulo de 90 graus, temos uma transição mais suave entre as duas hastes, contornando a geometria natural do terreno e criando um ângulo próximo de 120 graus entre as duas partes do L. É neste vértice que encontramos a torre de circulação com dois elevadores. 


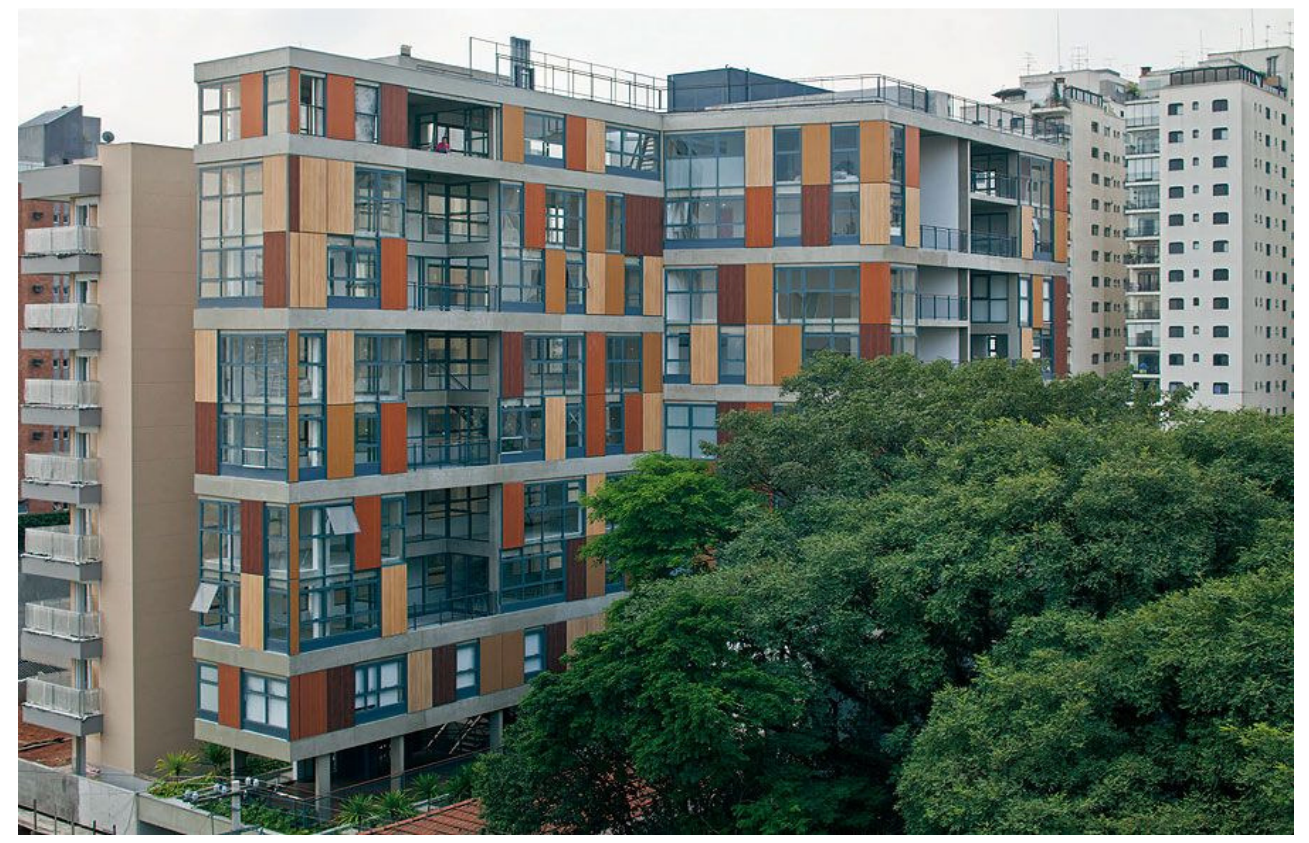

Figura 83- Vista geral do edifício. Foto: Nelson Kon

O acesso foi implantado na face mais estreita com $11 \mathrm{~m}$ de frente, enquanto a extensão mais ampla da construção se volta ao sul do terreno tendo o privilégio da vista para um arborizado terreno vizinho onde funciona uma escola pública. Para os autores, foi sorte ter esta face voltada para o sul, pois se pôde abrir a vista para a paisagem. Essa lateral, perpendicular à rua, recebe tem pouca insolação e com isso foi mais tranquilo para a dupla trabalhar com a mesma repleta de panos de vidro. 


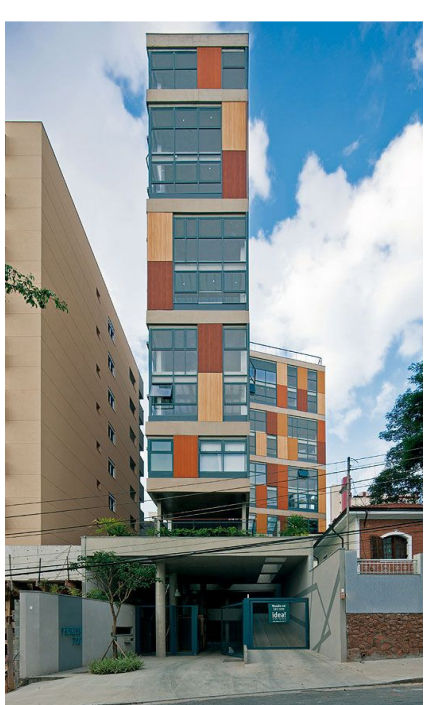

Figura 84- Vista geral do edifício. Foto: Nelson Kon

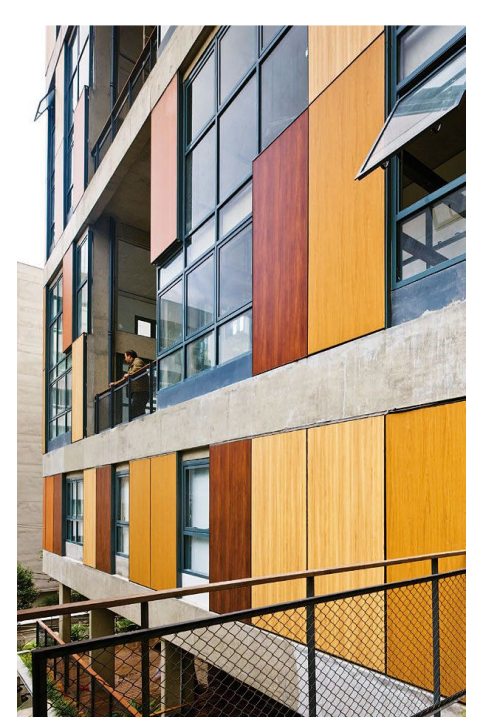

Figura 85- Vista geral do edifício. Foto: Nelson Kon

$\mathrm{Na}$ fachada norte, para proteção solar, estreitos brises de concreto foram projetados entre os andares [Figura 86]. Os caixilhos piso-teto ora são fechados por vidros, ora por painéis laminados especiais para fachadas. Unidos com as vigas de concreto aparentes, expõem no exterior as delimitações das unidades internas - e, portanto, expõem também suas variedades. A unidade do segundo andar da ala posterior, por exemplo, tem um único piso, o que a diferencia das unidades dúplex dos outros andares. Daí o desalinhamento na fachada do ritmo horizontal demarcado pelas vigas. Vista de longe, esta ganha um aspecto de mosaico em palheta reduzida. 


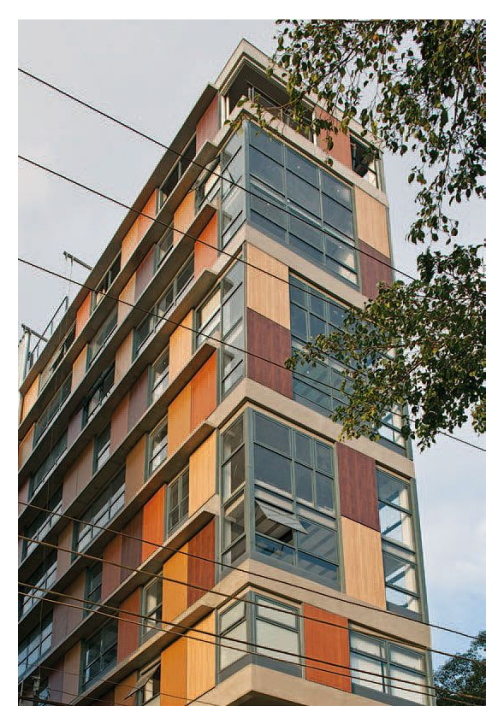

Figura 86-Vista geral do edifício. Foto: Nelson Kon

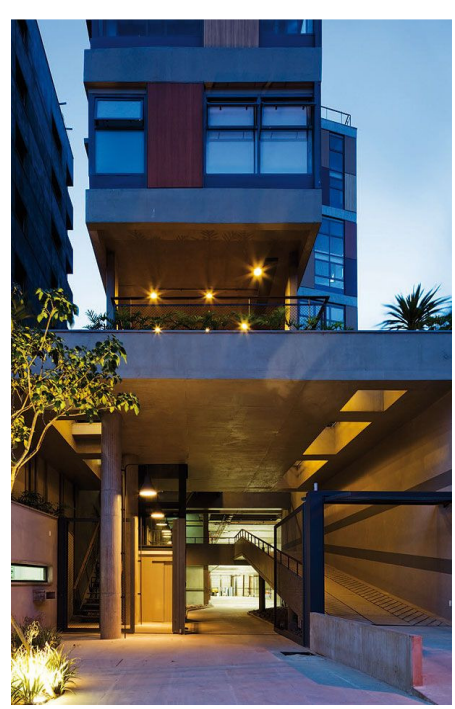

Figura 87- Vista geral do edifício. Foto: Nelson Kon

Outro desafio ainda foi oferecido pelo terreno aos arquitetos: um desnível de seis metros em relação à parte posterior do lote, o que resultou no afloramento dos dois níveis da garagem, deixando-os ao nível da rua principal. A entrada dos carros é feita entre pilotis e jardins. E, assim, o térreo se tornou elevado [Figura87].

Acima, elevam-se oito pavimentos em uma série de lajes livres que permitem a composição de 12 apartamentos de diferentes plantas que variam de $110 \mathrm{~m}^{2}$ a $220 \mathrm{~m}^{2}$, sendo algumas unidades duplex e a cobertura de três pisos com solário e piscina. 
Para Andrade, é como um jogo de encaixe, um quebra-cabeça em três dimensões: subtrai-se de um lado e aumenta do outro, cresce um lado e diminui o outro. Isso afeta também a circulação interna, fazendo que em alguns andares elevadores sirvam só um apartamento ao invés de dois. A variedade foi arquitetada para atender uma demanda do cliente, que pensou em um perfil de morador diferente para cada apartamento. Não há pilares e nem outras interferências estruturais nos interior das unidades. As lajes vencem o vão de todo o apartamento [Figura 88]. Este foi certamente, o maior desafio na execução da obra.

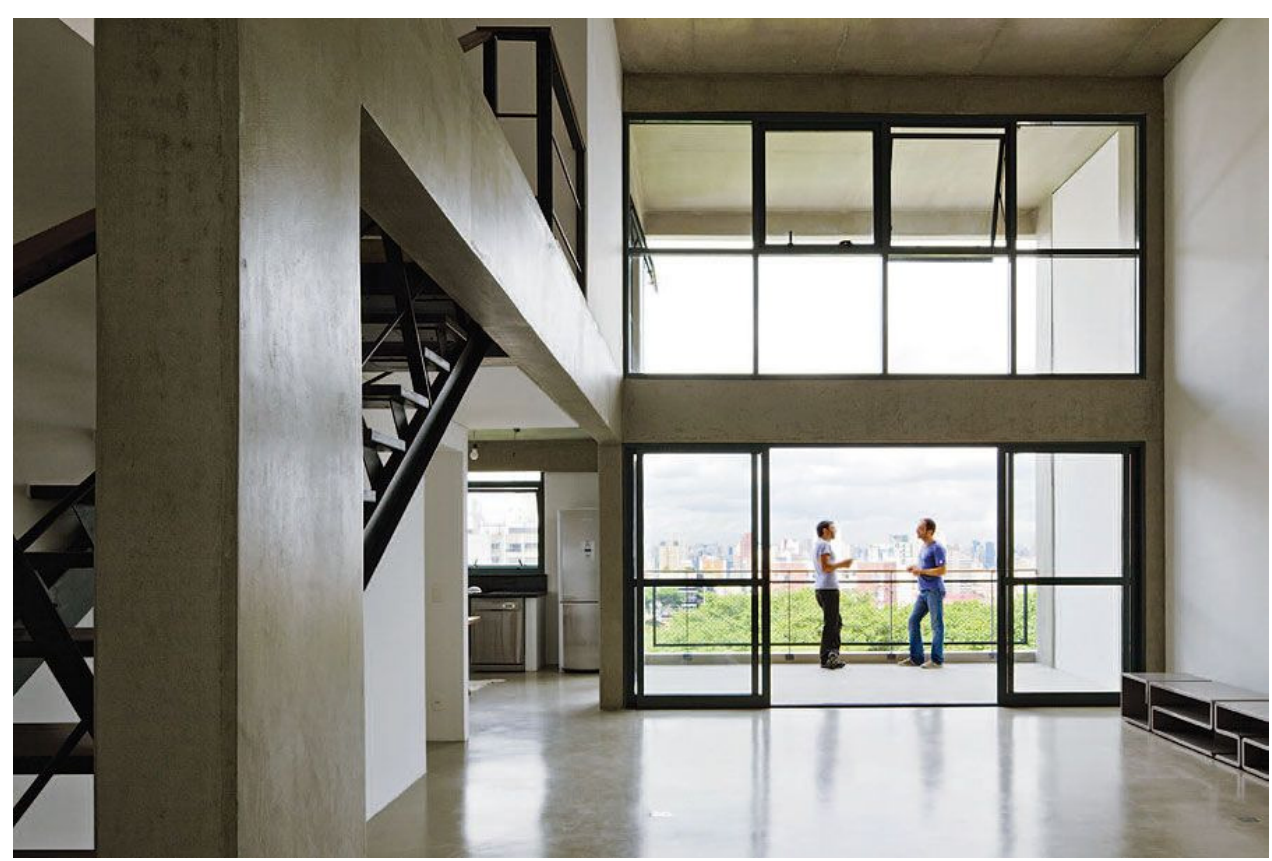

Figura 88- Vista interna de uma unidade duplex. Foto: Nelson Kon 
Pensando cada apartamento como uma concha vazia ou contêiner, segundo os autores, era necessário deixar os ambientes livres de obstáculos estruturais e ao mesmo tempo prover todos

os possíveis cômodos de serviços hidráulicos e elétricos. Assim, a distribuição de serviços está concentrada em colunas no perímetro da obra, multiplicando o número de prumadas de abastecimento. Os apartamentos têm todos os espaços servidos de infra-estrutura, de forma que cada proprietário pode definir a implantação interna como quiser.

Sem ornamentos, truques ou artifícios, é uma construção espartana - nas palavras dos arquitetos - de concreto, vidro, alumínio e painéis laminados. Mesmo em sua simplicidade, o prédio da Rua Fidalga parece amalgamar referências. Não nega um desejo de fluidez ao mesmo tempo em que ressalta suas origens ortogonais, o aspecto de membrana blocada que se integra ao ambiente de modo permeável, atravessada pela luz [Figura89]. 


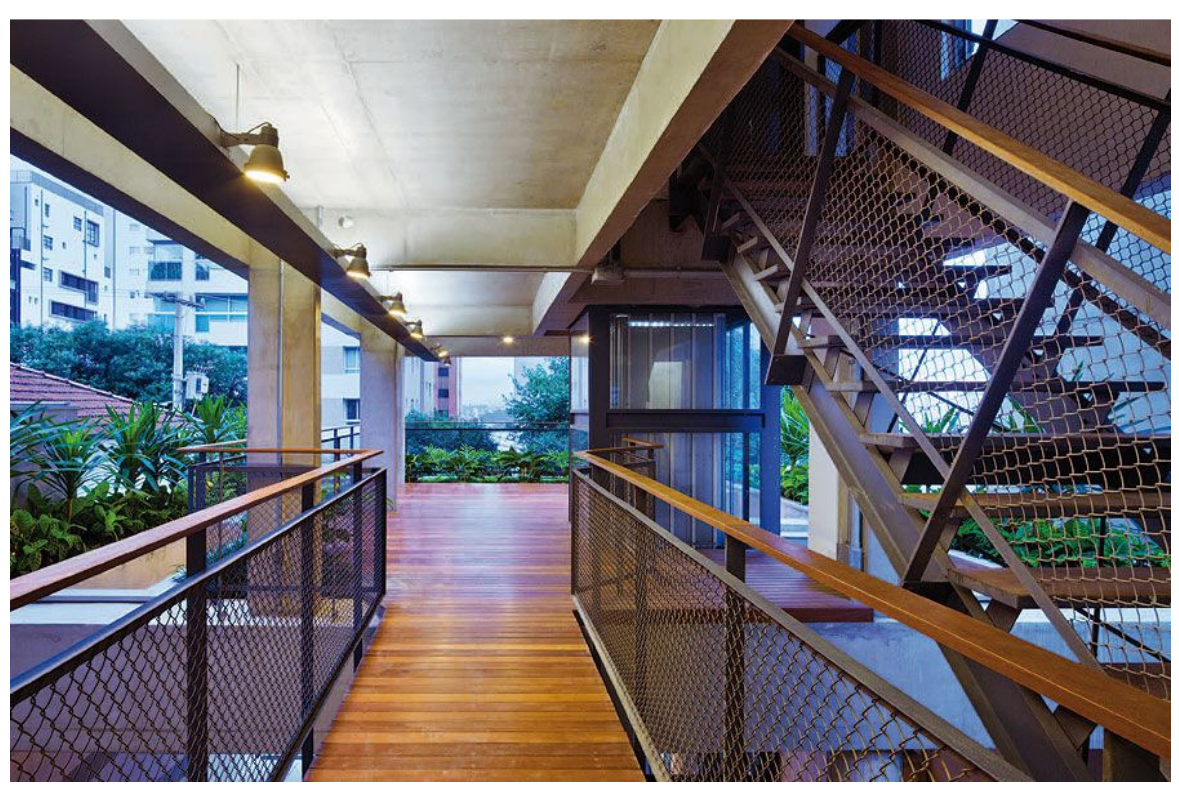

Figura 89 - Térreo elevado. Foto: Nelson Kon

Os arquitetos dialogam com os princípios da escola paulista na medida em deixa os materiais à flor da pele. Para os autores, com esse edifício, cria-se um elo com essa tradição, ao mesmo tempo em que se cria algo novo dentro do mesmo repertório. 
PROJETO EDIFÍCIO

FIDALGA 772

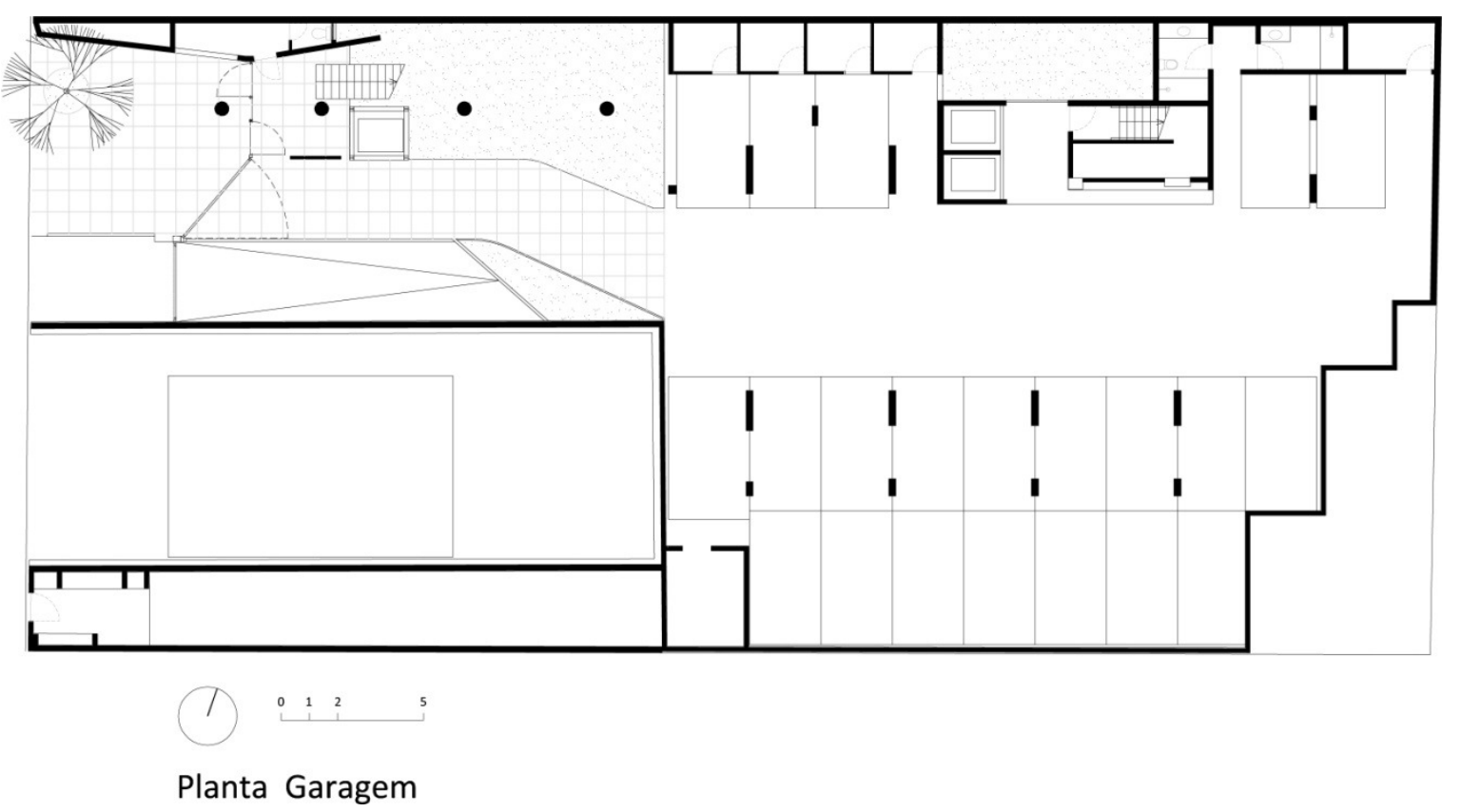




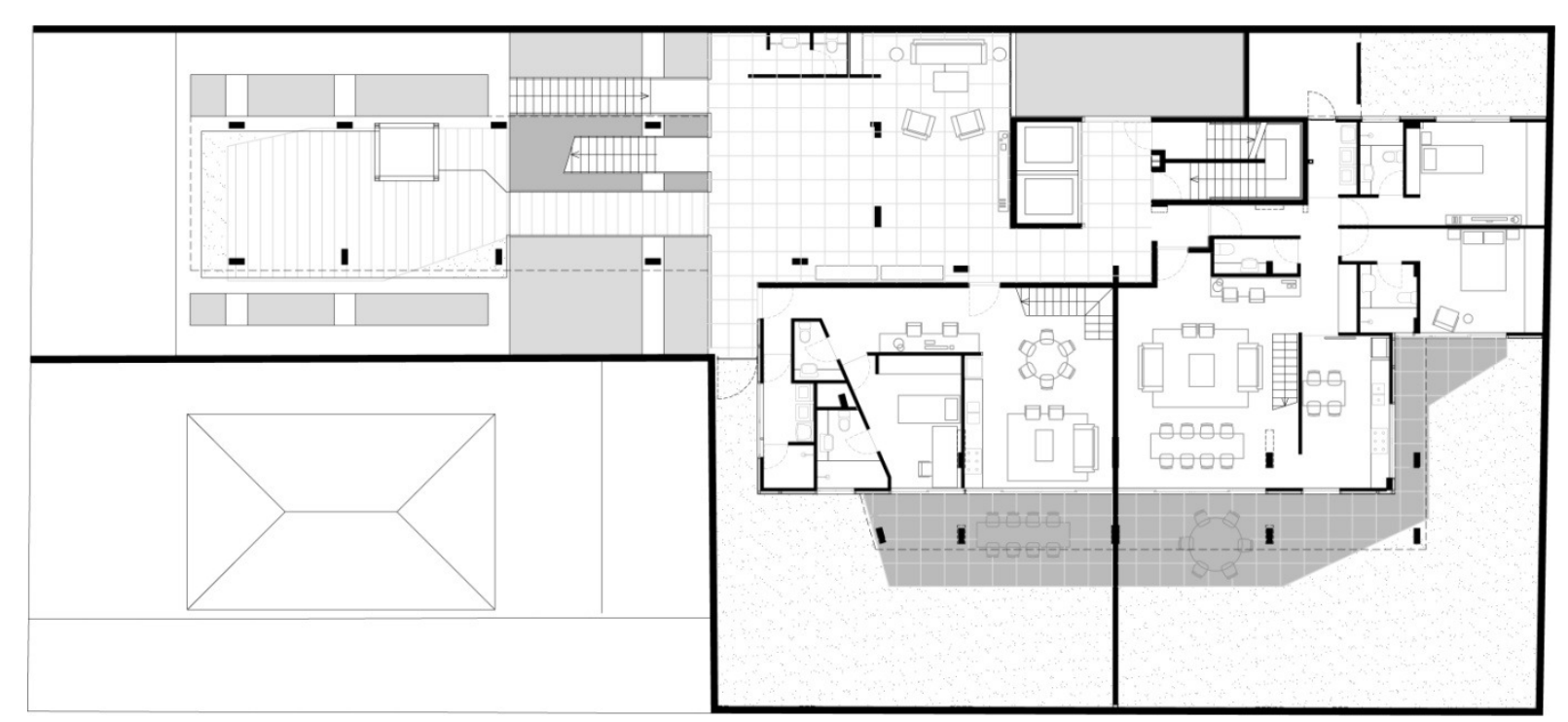

(1) $0^{12} 2^{2}$

Planta Pavimento Terreo 


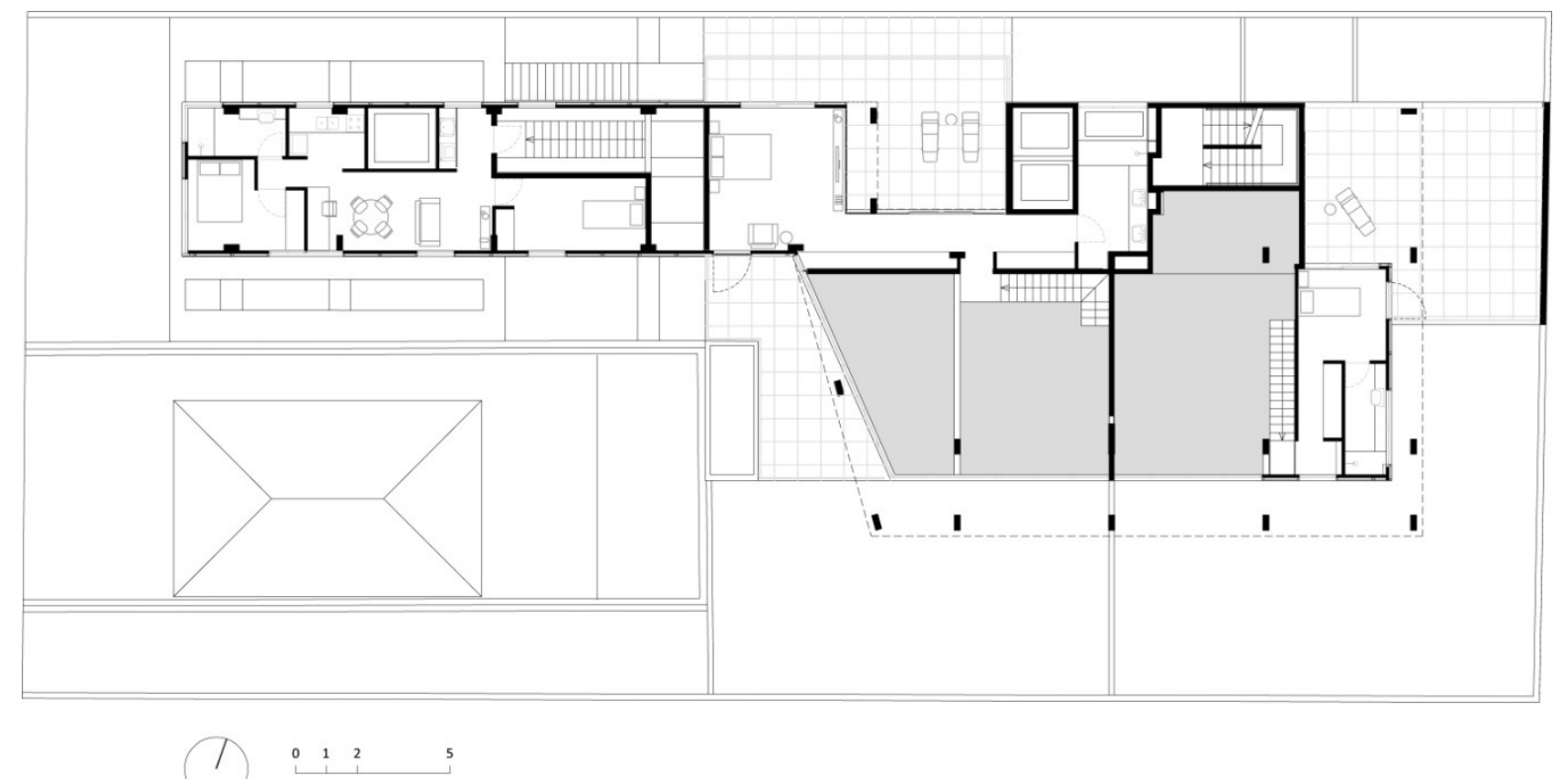

Planta 1을 Pavimento 

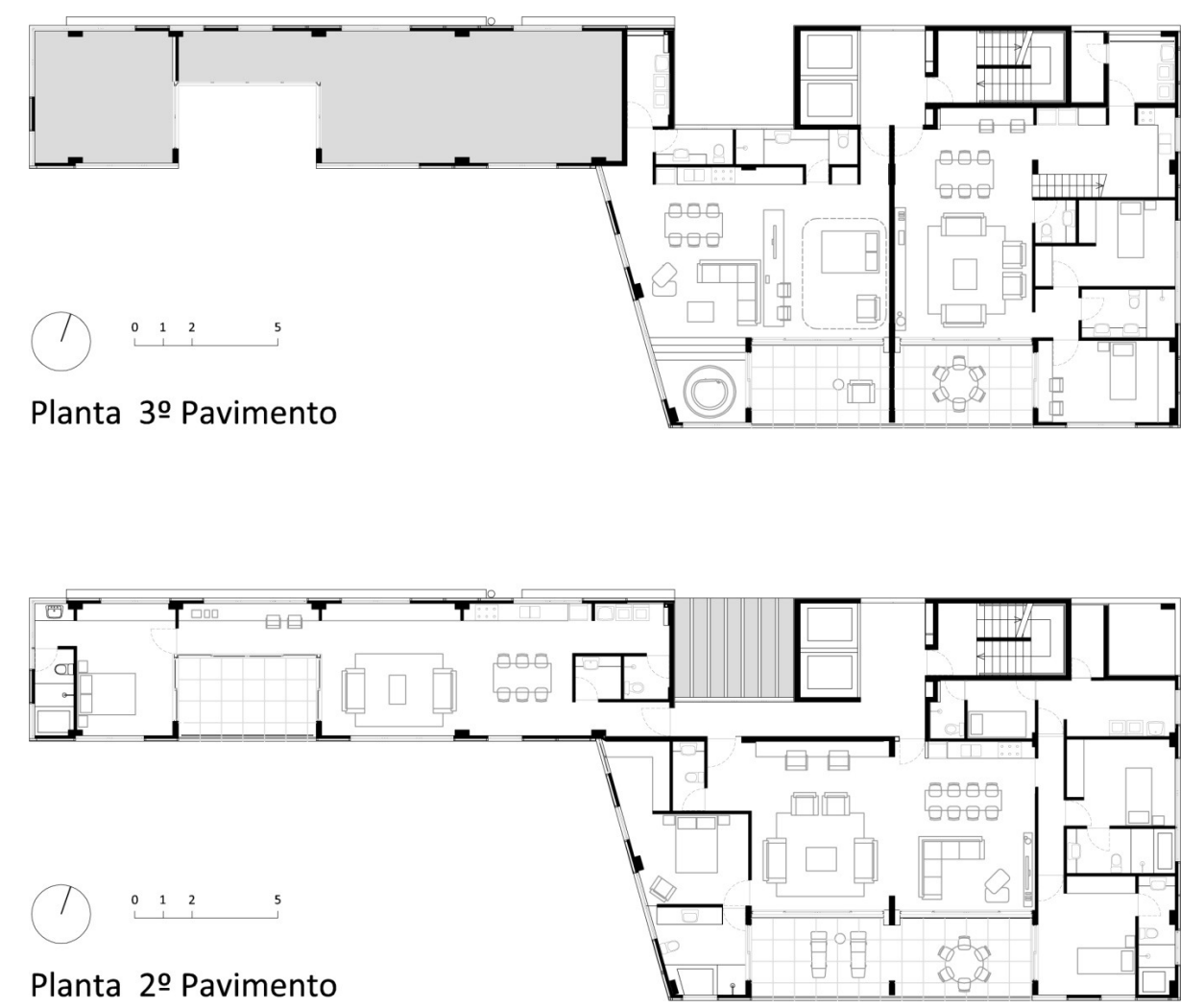

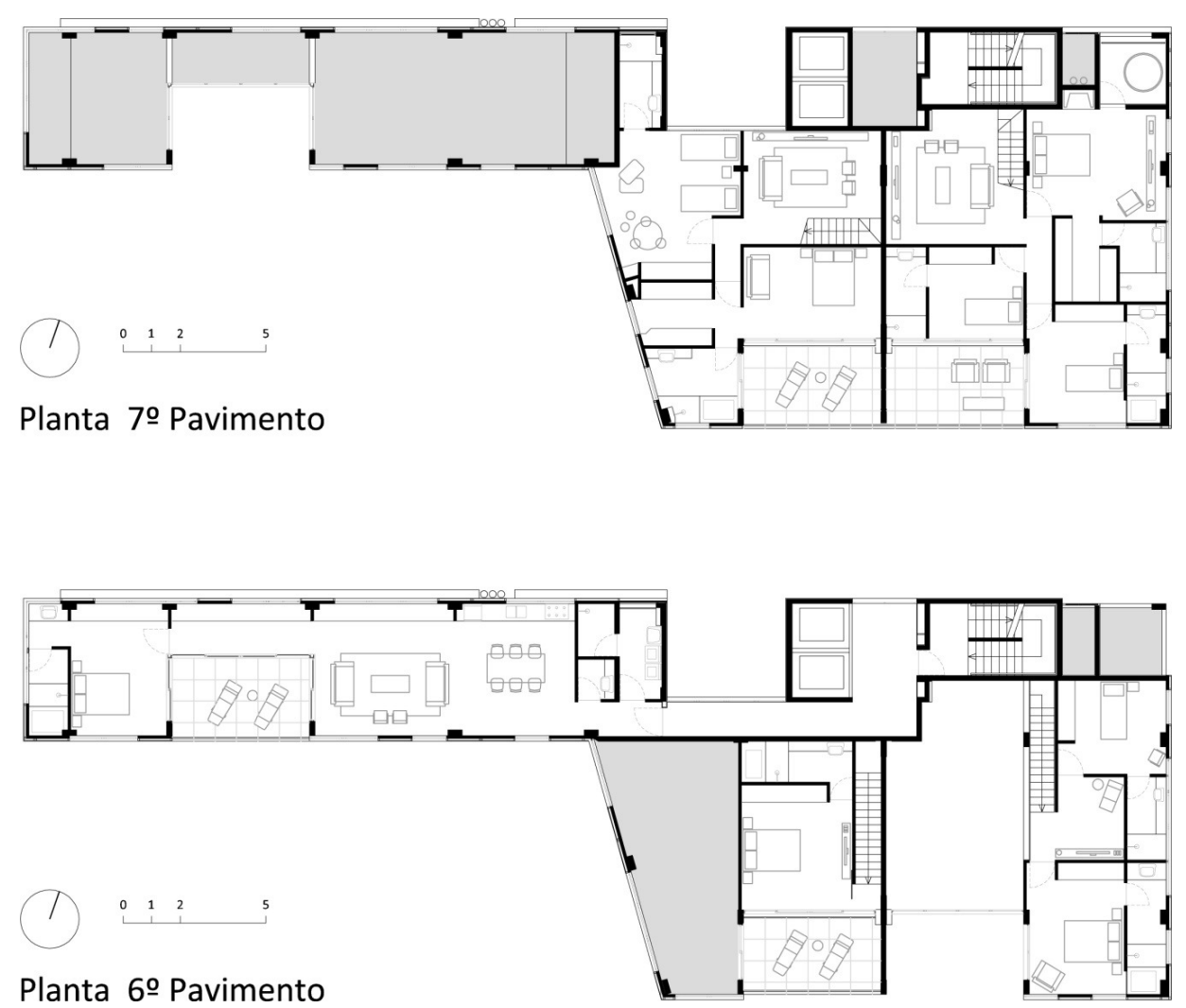

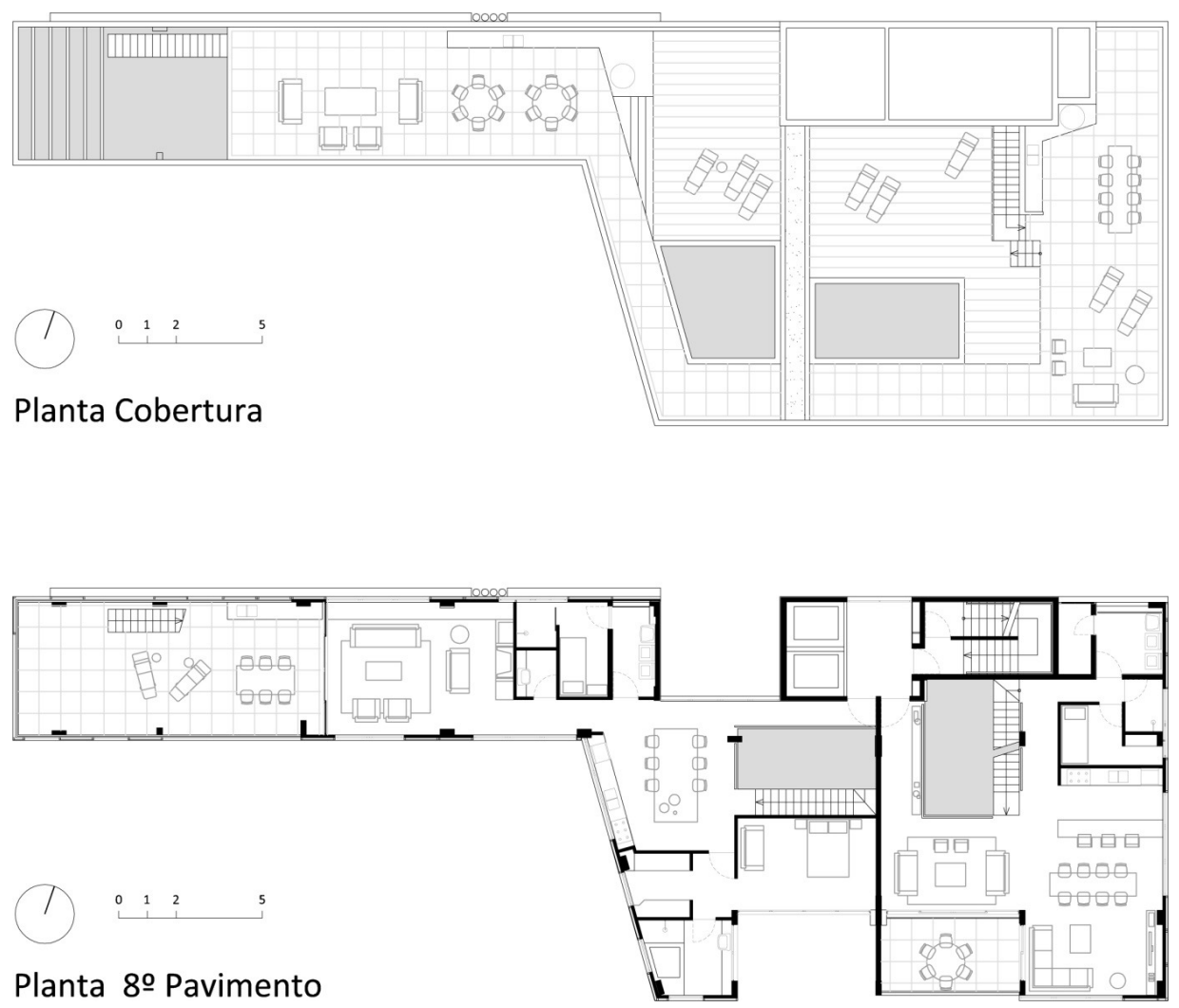


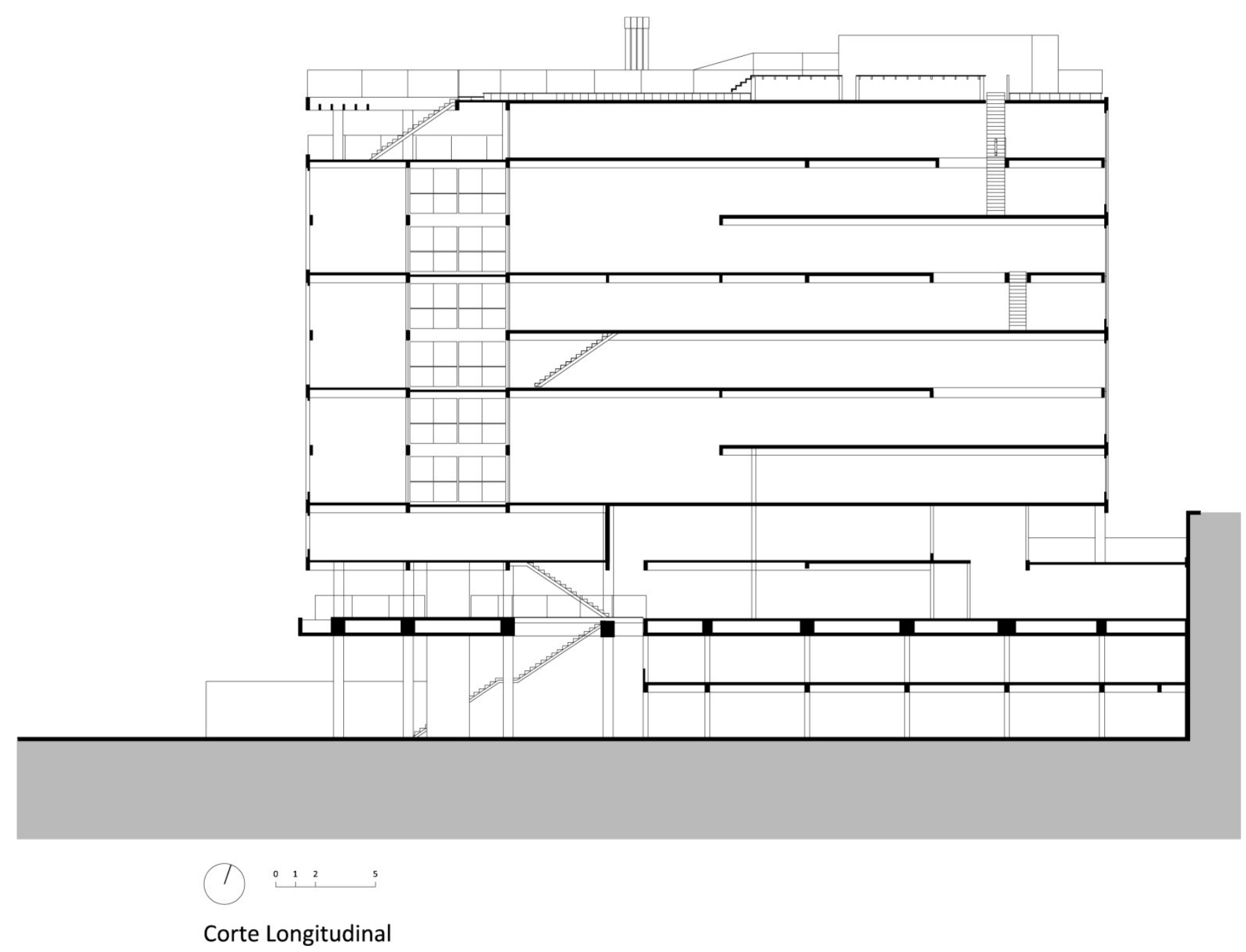




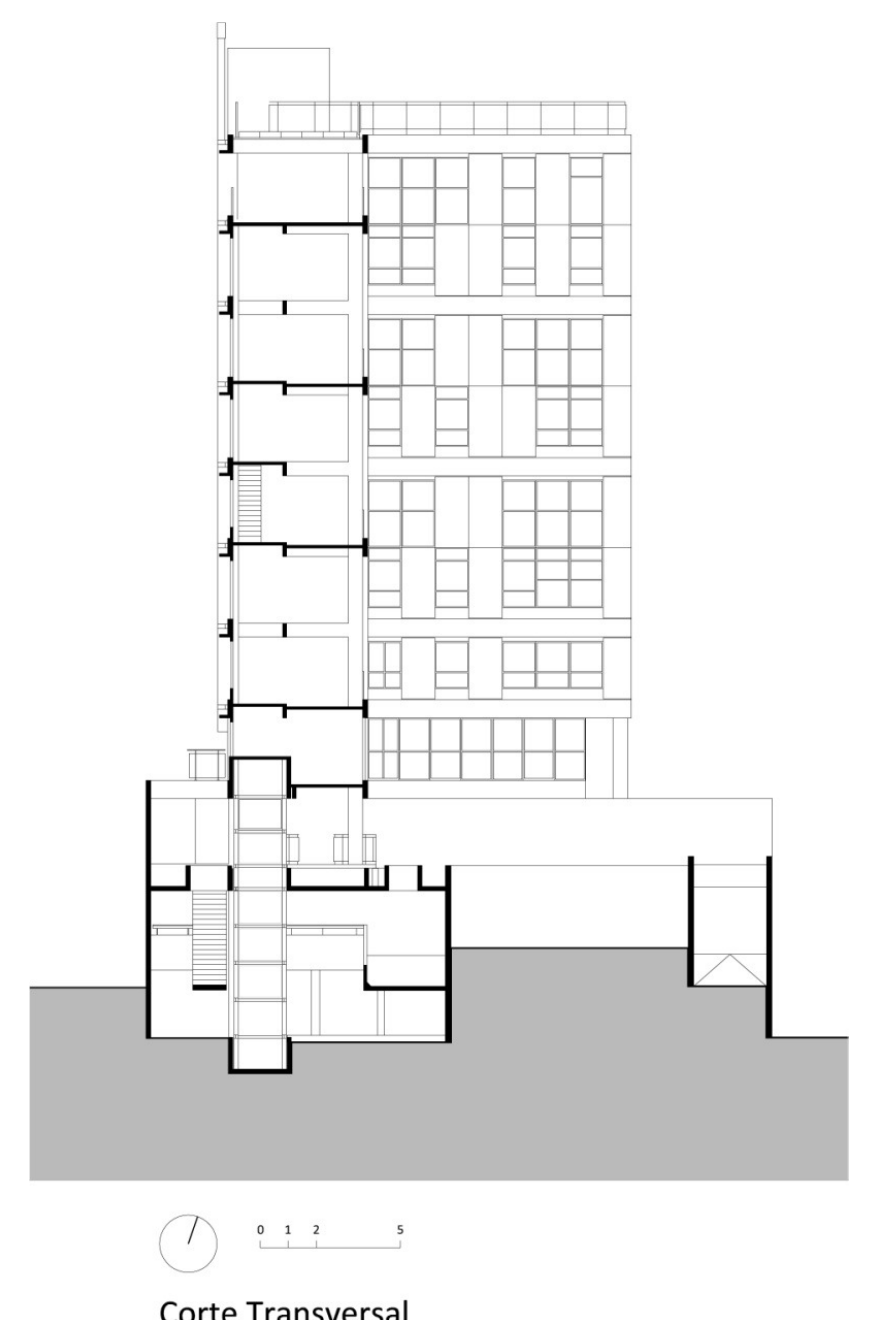




\subsection{IDEA! ZARVOS E 0 \\ ESCRITÓRIO \\ TRIPTYQUE}

O escritório Triptyque foi fundado em 1998, pelo ainda grupo de estudantes da Escola de Arquitetura Paris - La - Seine formado pela paulista Carolina Bueno e os franceses Guillaume Sibaud, Olivier Raffaelli e Gregory Bousquet. Em 2000 trazem sua base da Paris consolidada, com limitado espaço aos jovens arquitetos, para o Brasil, mais precisamente para a cidade do Rio de Janeiro. Em 2003, uma nova mudança. Agora o escritório se instala em São Paulo. Para o arquiteto Olivier Raffaelli, Rio de Janeiro e São Paulo são cidades novas no formato urbano e apresentam um desafio interessante.

Destacando-se através de uma linguagem internacionalizada e com certos arrojos aliados à customização e aplicação de conceitos de sustentabilidade, o Triptyque conquista atualmente o posto de um dos escritórios promissores do país. Para os arquitetos, o escritório enfrenta a problemática das cidades emergentes desenvolvendo um método de trabalho com ferramentas de questionamento que visam modificar a evolução dos espaços urbanos. A metodologia de trabalho do quarteto é iniciar seus projetos sempre com a discussão em grupo, a partir de colaborações múltiplas, trabalhando diversas idéias para eleger a mais consistente e então, dar desenvolvimento ao projeto.

Na produção do escritório, merecem destaque os projetos Colômbia 325 - ex - agência publicitária Loducca [Figura 90] e o Harmonia 57 - loja FARM [Figura 91], 1o prêmio na Bienal Internacional de Arquitetura de São Paulo em 2009. 


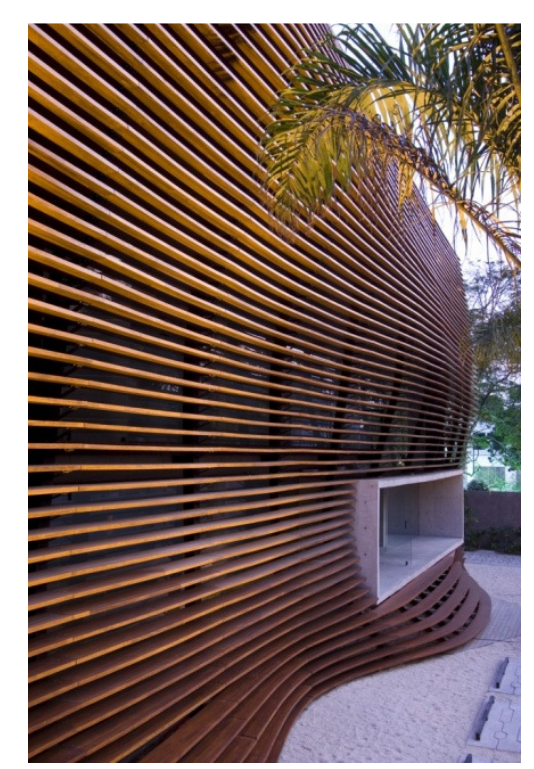

Figura 90 - Colômbia 325. Foto: Fran Parente

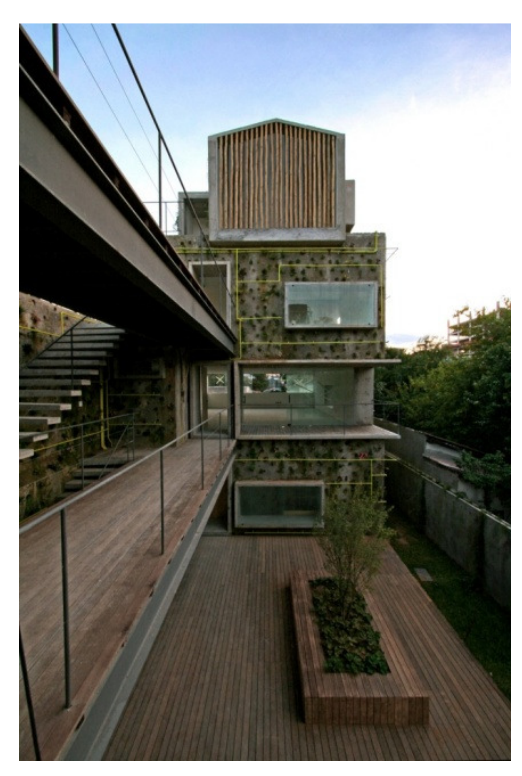

Figura 91 - Harmonia 57. Foto: Beto Consorte

O trabalho do grupo pretende resumir a combinação de muitos personagens e disciplinas traduzidas no anseio de superação aos repertórios comumente aceitos e integração do novo acordo sobre a responsabilidade social e ambiental. 


\section{EDIFÍCIO FIDALGA 727}

O edifício Fidalga 727, foi o segundo empreendimento da Movimento Um, sendo entregue em 2010. O projeto data de 2007. Localizado na Rua Fidalga [Figura 92], logo à frente do projeto de Andrade Morettin já mencionado neste trabalho, portanto na mesa Zona Mista de Média Densidade - ZM - 2/07. Seu terreno mede $666 \mathrm{~m}^{2}$ e foram construídos $2.778 \mathrm{~m}^{2}$, configurados em subsolo, térreo e oito pavimentos.

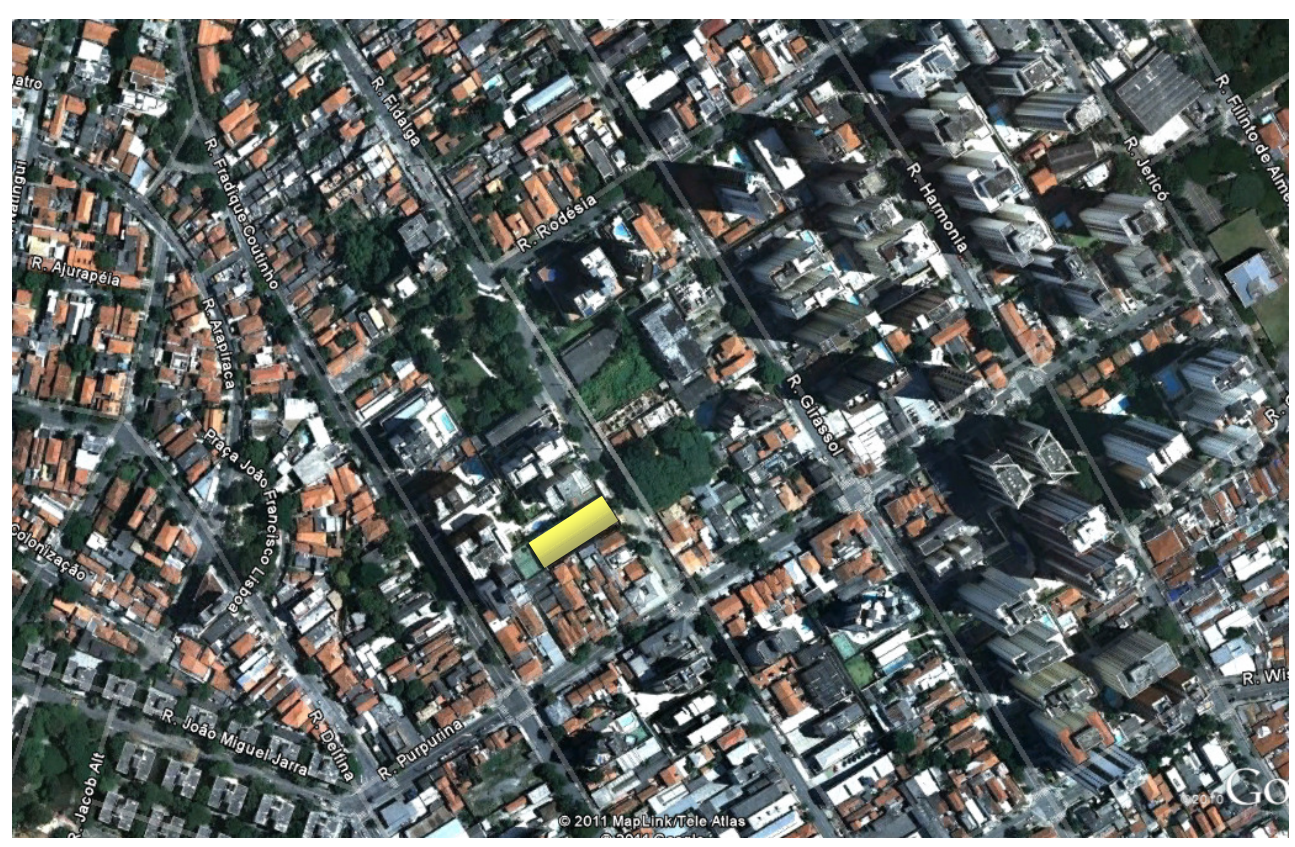

Mapa de localização - Fonte: Google Maps 2011 
Segundo os arquitetos, foi a partir do questionamento de modelos racionalistas que surgiu a busca pela harmonização das soluções e elaboração de uma proposta conceitual para um edifício-casa que fragmenta os elementos constitutivos comuns estabelecendo diálogo com a riqueza caótica do bairro. O edifício foi dividido em dois blocos de concreto, ora aparente, ora revestidos por tijolos e vidro; interligados por um terceiro volume, que abriga a circulação vertical. Os apartamentos ocupam a totalidade da laje, resultando em 11 unidades assimétricas, com sete diferentes tipologias: simples ou dúplex, do loft à unidade com três suítes. As áreas das unidades variam entre $79 \mathrm{~m}^{2}$ e $\mathbf{2 8 1 \mathrm { m } ^ { 2 }}$, dimensão que corresponde à cobertura dúplex com terraço [Figuras 93 e 94].

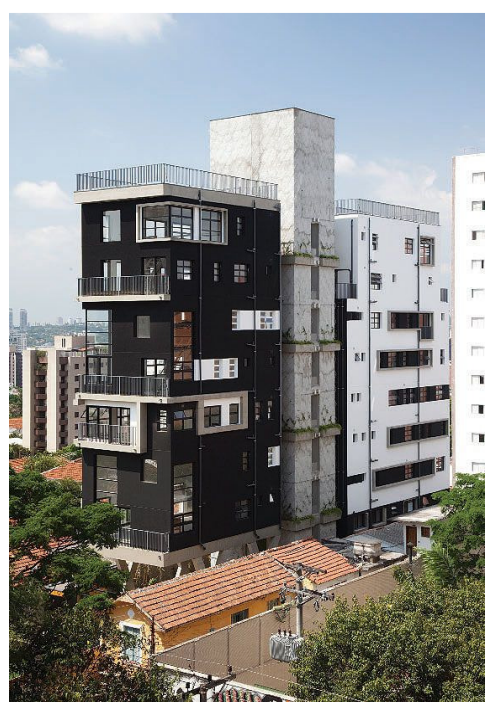

Figura 93 - Fidalga 727 - Foto: Fran Parente

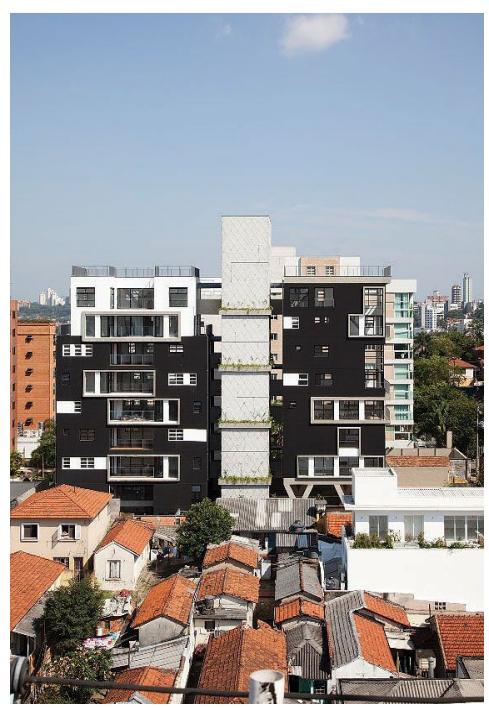

Figura 94 - Fidalga 727 - Foto: Fran Parente 
O primeiro bloco está apoiado em uma seqüência de pilares de concreto em X [Figura 95], liberando o térreo para o jardim, que começa ainda no espaço público, passa pelo acesso e ganha continuidade na torre de circulação vertical. O segundo volume se apoia diretamente no solo, com um apartamento térreo [Figura96].

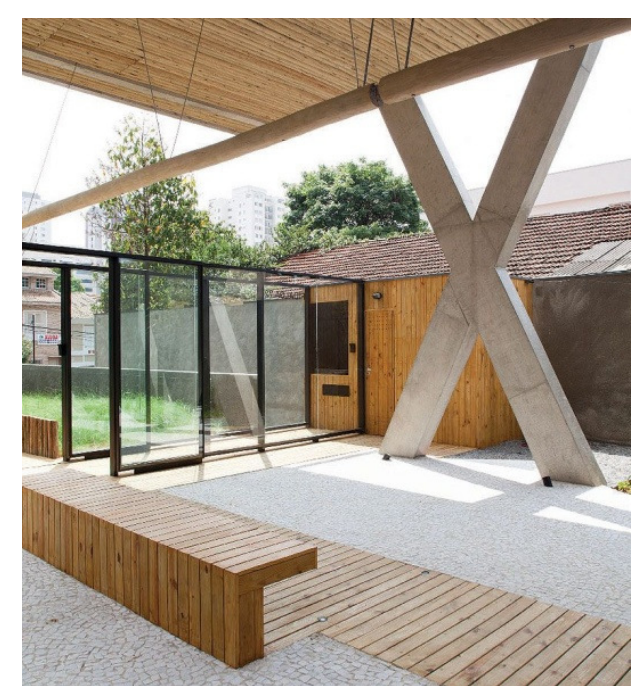

Figura 95 - Fidalga 727 - Foto: Fran Parente

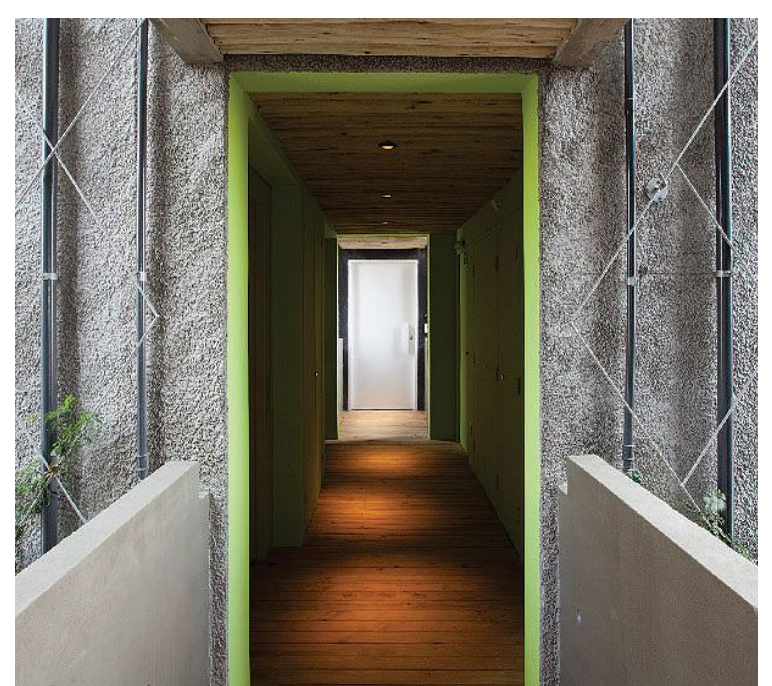

Figura 96 - Fidalga 727 - Foto: Fran Parente

Para individualizar as unidades, a proposta arquitetônica estabeleceu posicionamentos diferentes para as varandas e criou um jogo de aberturas livre de modulações repetitivas, recursos que também dinamizaram e tornaram mais atraentes as fachadas. Todos os apartamentos são privilegiados por vistas panorâmicas e farta ventilação natural, assegurada por aberturas em 
todas as faces. As grandes aberturas foram idealizadas pelos autores, porém as menores, determinadas pelos proprietários e adequadas nas fachadas pelos arquitetos [figuras 97 e 98].

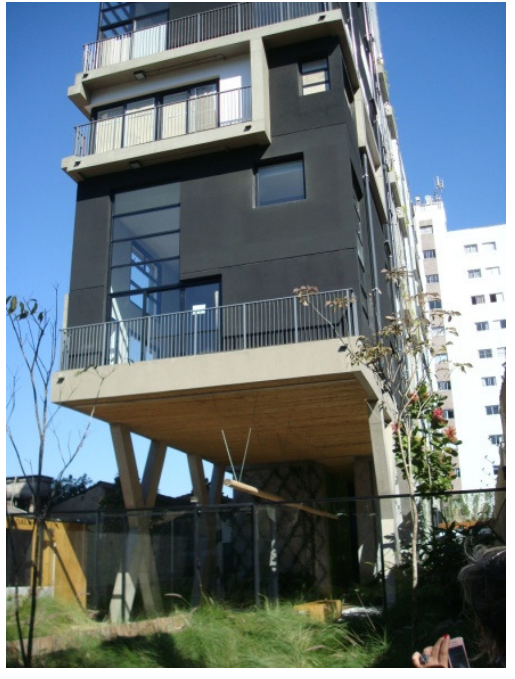

Figura 97 - Fidalga 727 - Foto: Fran Parente

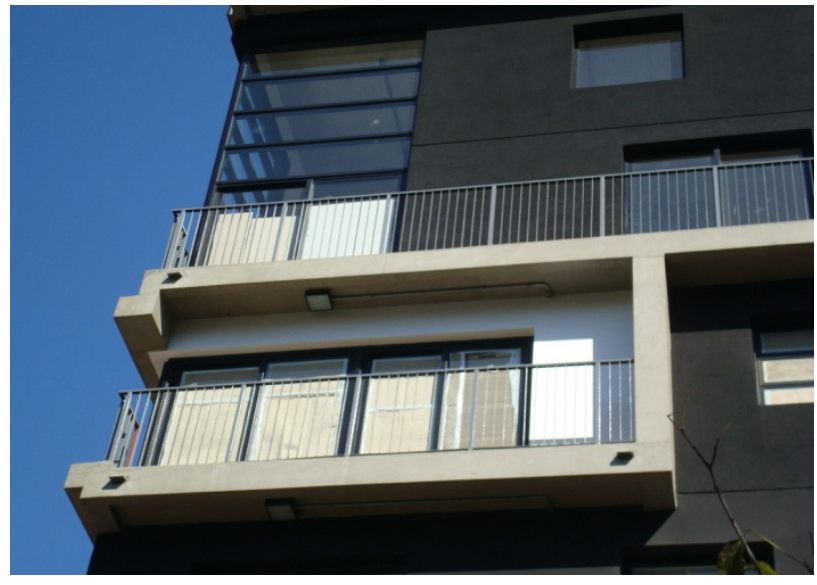

Figura 98 - Fidalga 727 - Foto: Fran Parente

Voltadas para a rua, as passarelas de circulação que interligam os dois blocos também respondem pelo acesso aos apartamentos. Segundo um dos autores do projeto, Guillaume Sibaud, as moradias foram entregues como contêineres, o que permitiu diversas possibilidades de layout para atender às necessidades específicas de cada comprador. O layout das unidades e suas respectivas fachadas acompanham os conceitos de liberdade e diversidade pregados pelos arquitetos. Aqui, banheiros, salas e quartos não se empilham no sentido vertical e se rebatem nos 
andares. Toda essa padronização foi trocada pela customização, o que para uma construção significa um tempo incrivelmente maior de projeto e construção. Essa flexibilidade foi obtida graças ao posicionamento de todos os elementos estruturais na periferia das unidades [Figuras 99 e 100].

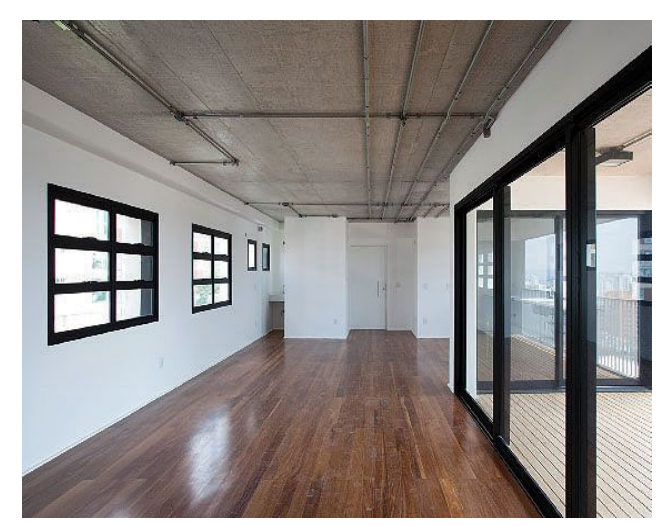

Figura 99 - Fidalga 727 - Foto: Fran Parente

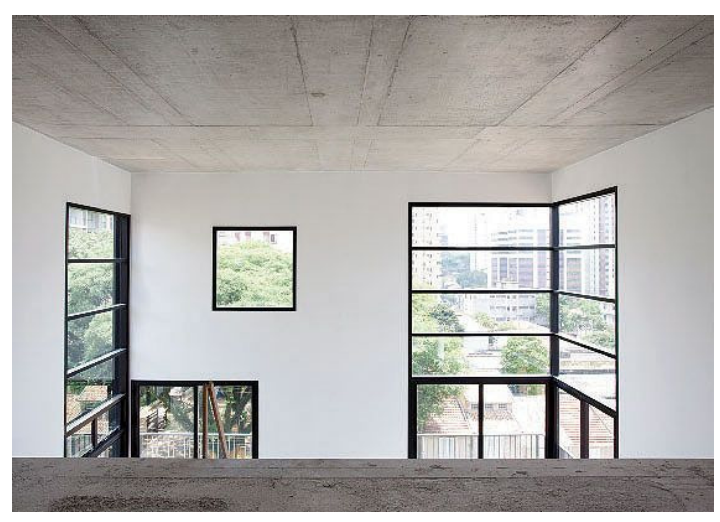

Figura 100 - Fidalga 727 - Foto: Fran Parente

Para resolver o problema das áreas molhadas, imutáveis na maioria dos edifícios, as tubulações são embutidas nas lajes dos apartamentos e correm em direção às prumadas de água e esgoto estrategicamente posicionadas nas fachadas, e aparentes. Segundo os autores, o resultado final integra elementos previstos e não previstos, tornando o edifício mais interessante. 
O Fidalga 727 carrega fortes conceitos de urbanidade e industrialização, com recortes enquadrados por uma simplicidade formal, tubulações aparentes e um elemento a mais de diferenciação: sua cor. O preto do edifício não nega nem se esconde da urbanidade paulista e do asfalto para o qual se volta e em breve entrará em harmonia com o verde que um dia recobrirá o bloco de circulação. 
PROJETO

FIDALGA 727

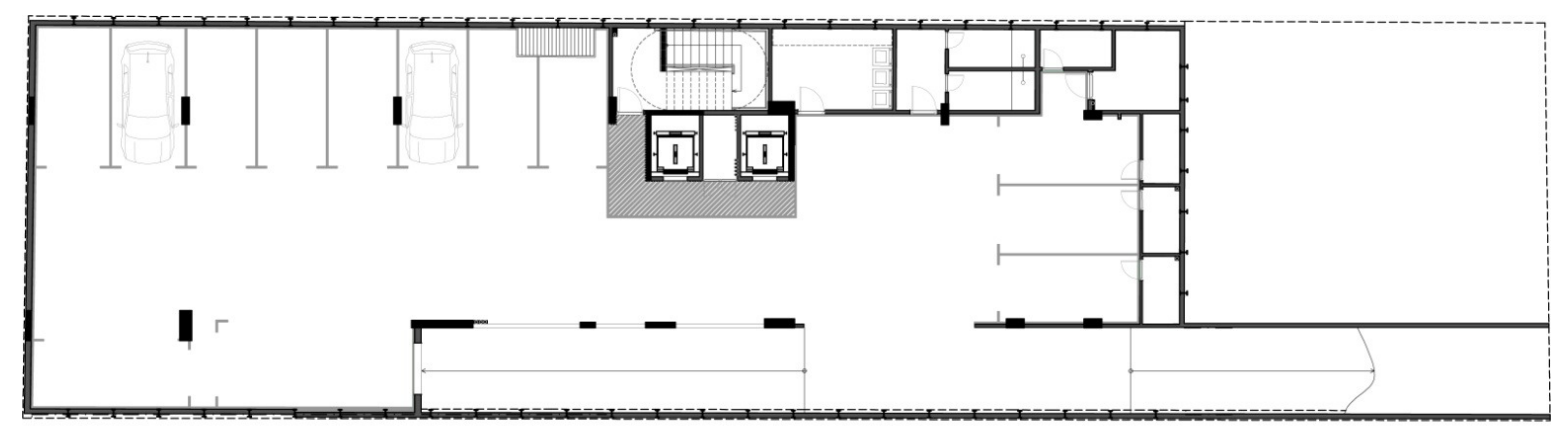

$(1)^{1} 2^{5}$

Planta 10 Subsolo

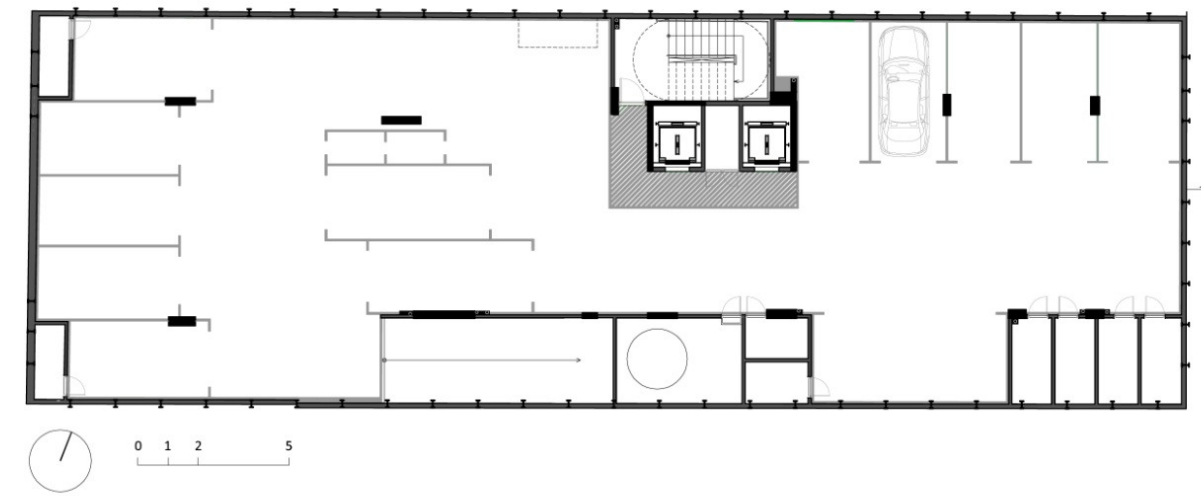

Planta 2온 Subsolo 


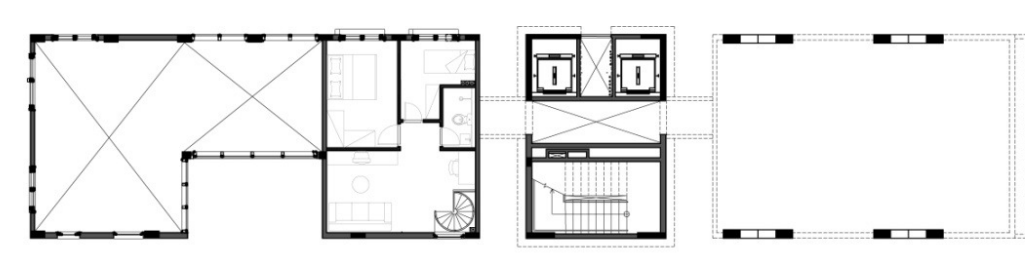

Planta 10 Pavimento

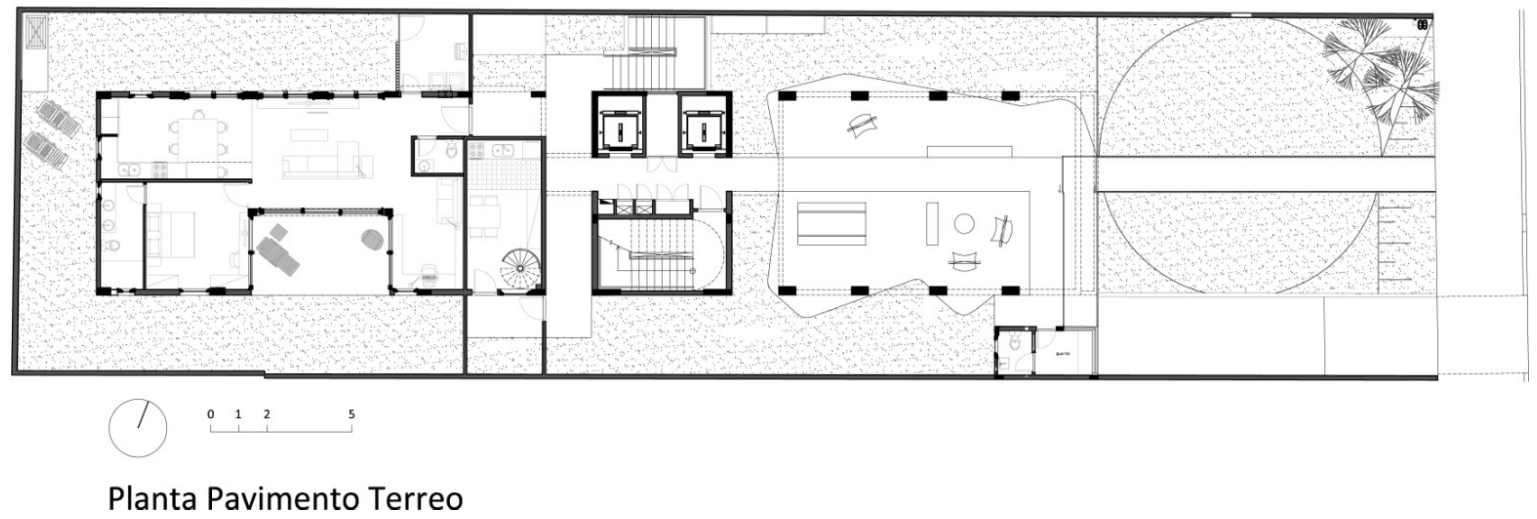




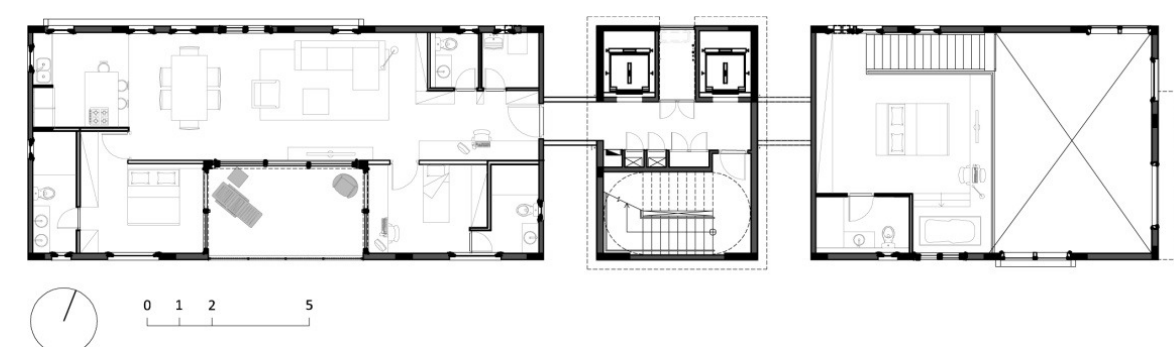

Planta 3 e 6o Pavimento

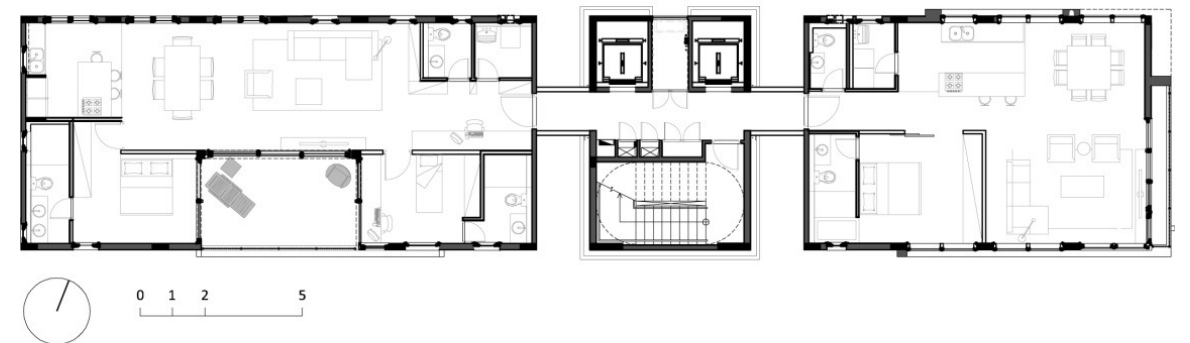

Planta 40 Pavimento

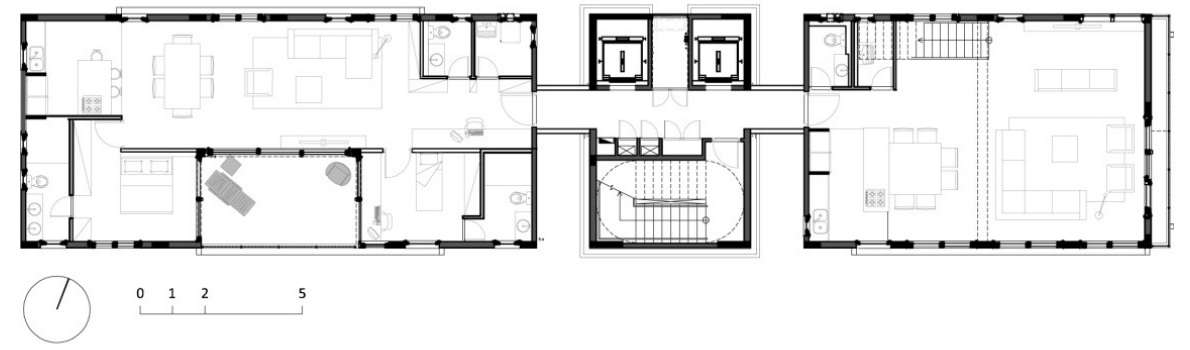

Planta 2ㅇ e 5o Pavimento 


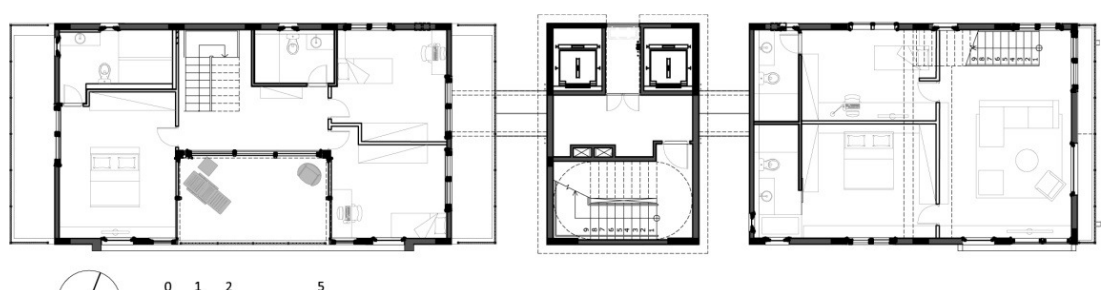

(1) $\begin{array}{llll}0 & 1 & 2 \\ 1 & 1 & 1\end{array}$

Planta Cobertura 70 Pavimento

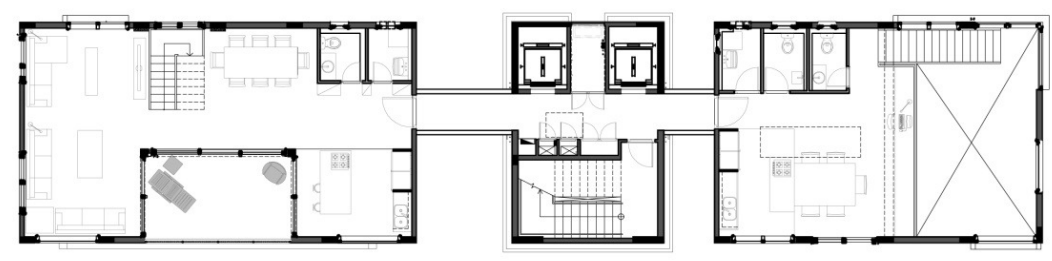

(1) $\begin{array}{llll}0 & 1 & 2 \\ 1 & 1 & 5\end{array}$

Planta Cobertura 8o Pavimento

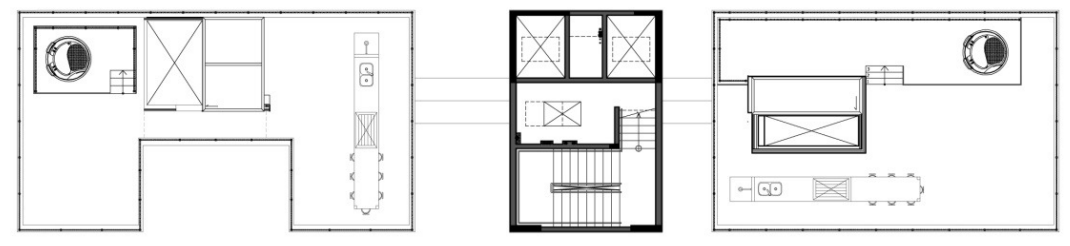

Planta Cobertura 9o Pavimento 


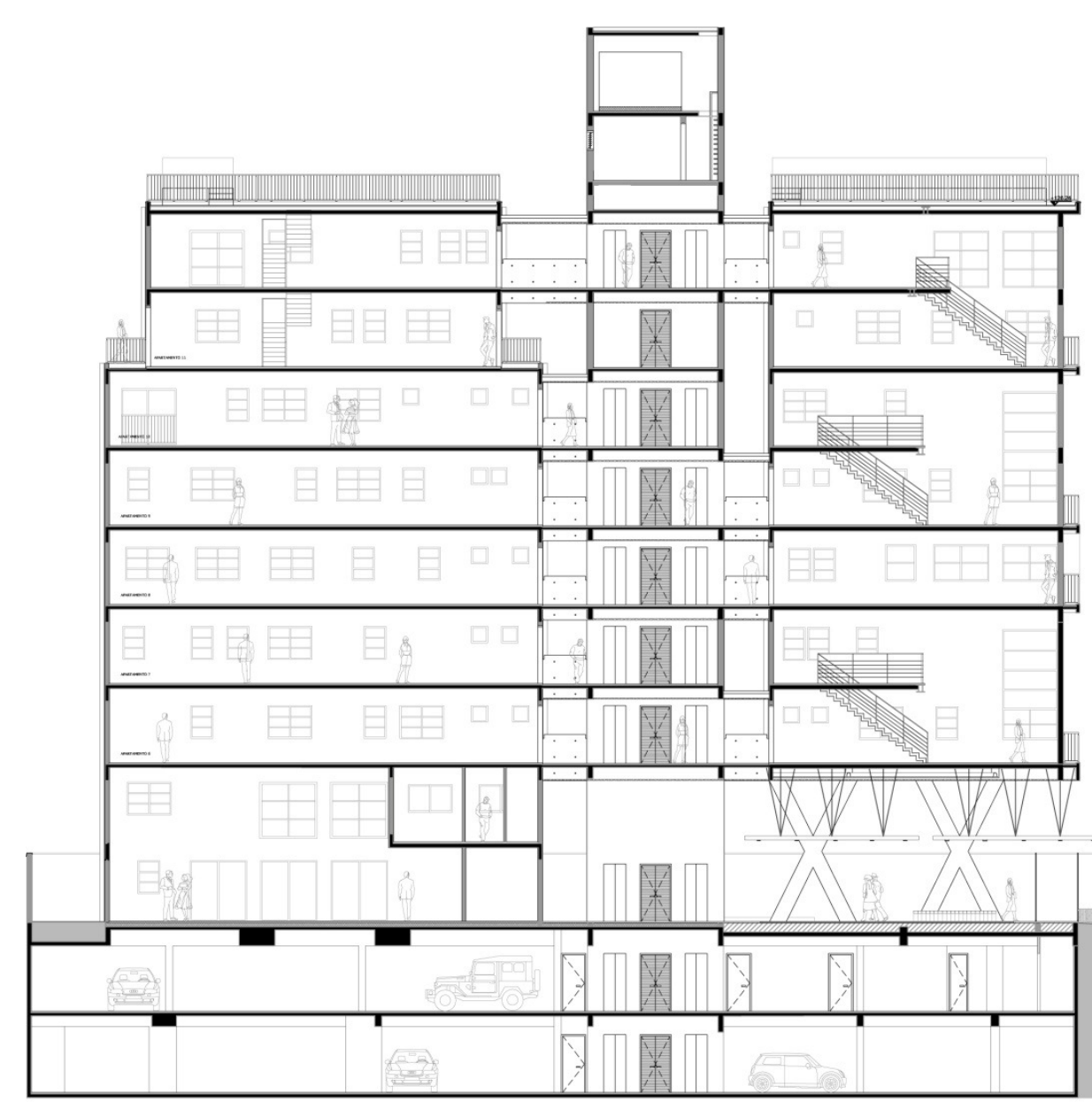

$(1) 0^{1} 1^{2}$

Corte Longitudinal 


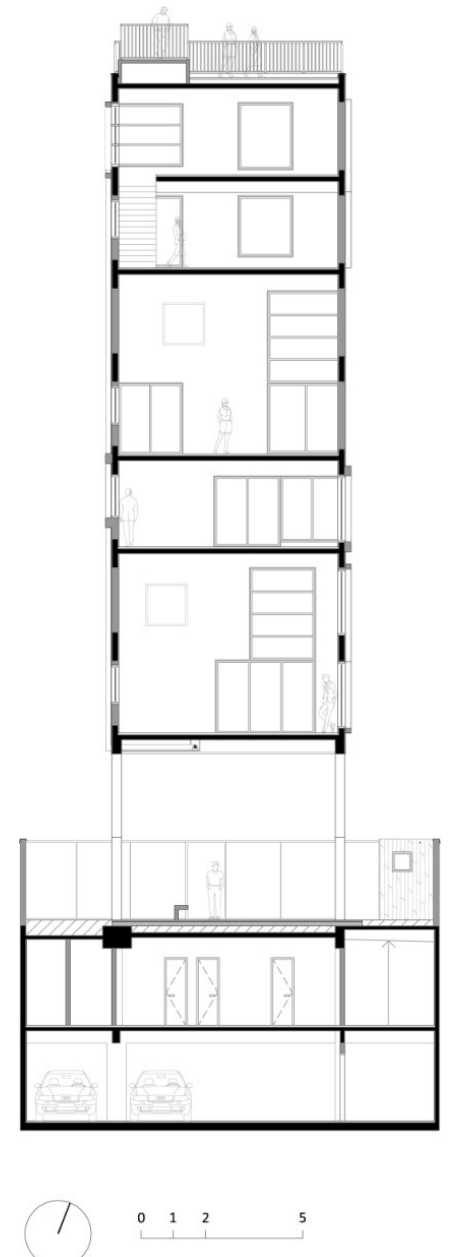

Corte Transversal 


\subsection{IDEA! ZARVOS E 0}

ESCRITÓRIO

GRUPO SP
O Grupo SP surgiu em 2004 a partir da associação de arquitetos formados em diferentes momentos que se reuniram para desenvolver concursos e projetos de arquitetura. Atualmente o grupo é composto por dois sócios, Álvaro Puntoni e João Sodré e mais três arquitetos colaboradores. O grupo defende a crença de que não há mais escritórios de arquitetura e sim arquitetos. Sendo assim, apostam numa estrutura enxuta com uma organização flexível que se abre a outras parcerias, conforme a demanda de trabalho. Defendem fortemente a importância dos concursos de arquitetura como forma de debate e possibilidade de inserção profissional, além da perspectiva de realização do projeto com um número menor de interferências, tão comuns nos trabalhos cotidianos.

Merece destaque dentro da produção do escritório o projeto para a sede nacional do SEBRAE em Brasília, primeiro prêmio em concurso realizado pelo Instituto dos Arquitetos do Brasil - Distrito Federal em 2008 [Figura101].

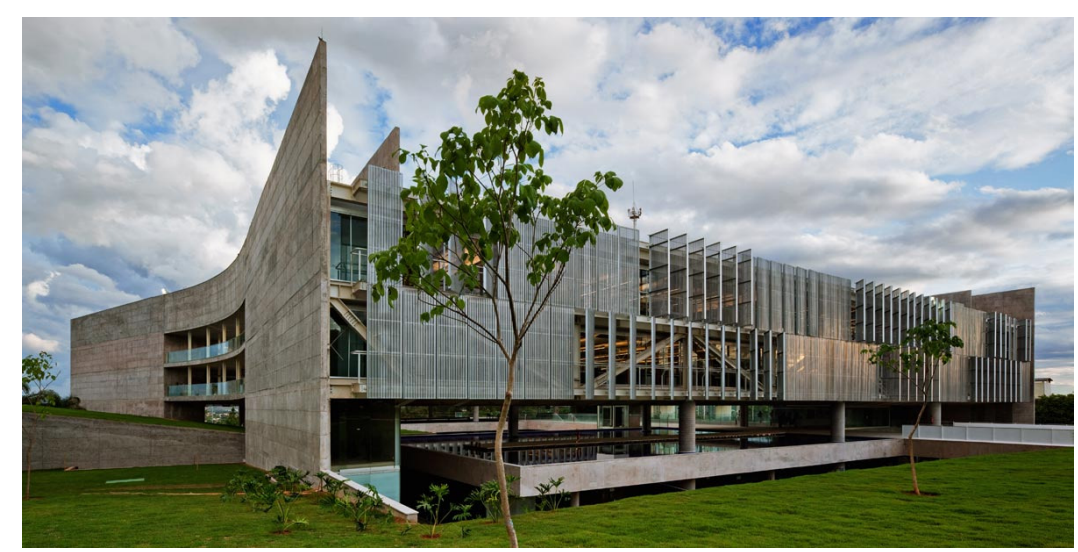

Figura 101 - Sede Nacional SEBRAE, Brasília. Fonte: Grupo SP 
A parceria do escritório com a Idea!Zarvos surgiu em 2006 quando os arquitetos procuraram o incorporador para apresentar um projeto - estudo para um edifício residencial no bairro de Pinheiros [Figura 102]. Não houve o interesse para aquele estudo em si, mas em seguida Otávio Zarvos os contrata para a realização do projeto do edifício Simpatia.

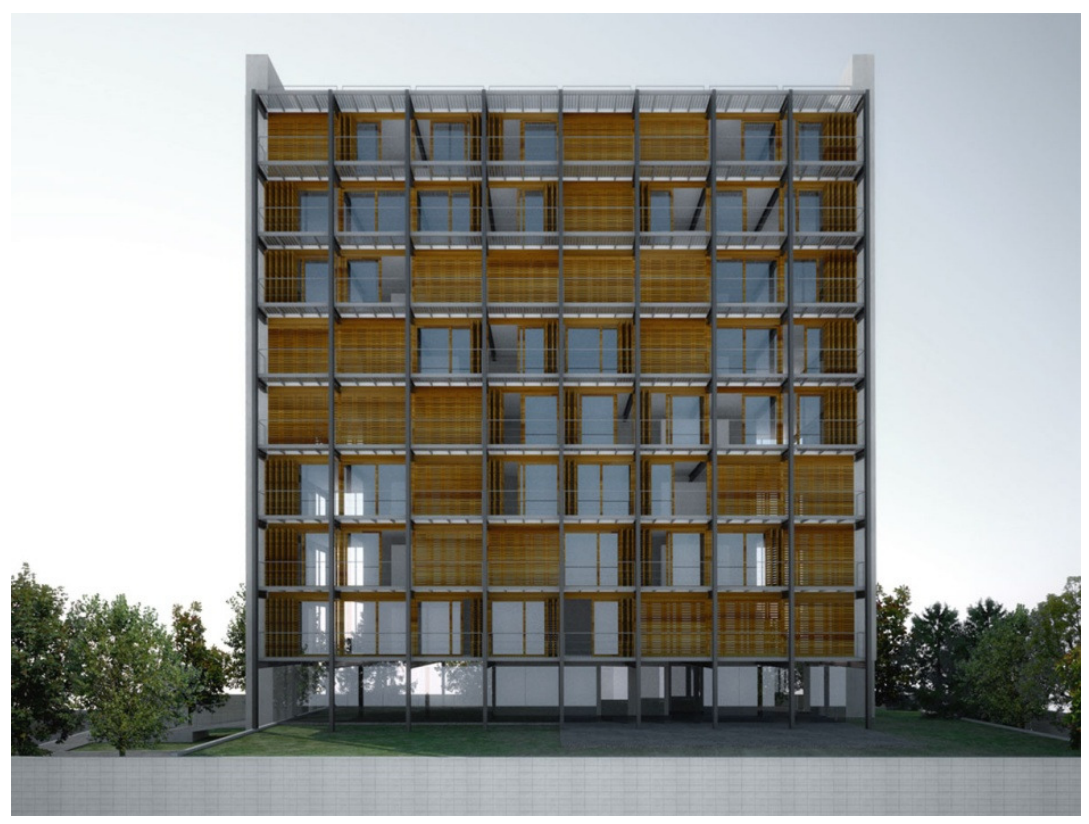

Figura 102 - Estudo para edifício residencial em Pinheiros. Fonte: Grupo SP 


\section{EDIFÍCIO SIMPATIA 236}

O Edifício Simpatia 236, também localiza-se no bairro da Vila Madalena, portanto na mesma Zona Mista de Média Densidade - ZM - 2/07 [Figura 103]. Seu projeto data de 2007, sendo entregue aos usuários em 2011. Foram $3.000 \mathrm{~m}^{2}$ construídos em $800 \mathrm{~m}^{2}$ de terreno. Contempla 13 unidades que variam de $90 \mathrm{~m}^{2}$ a $210 \mathrm{~m}^{2}$, distribuídos em oito andares, além do térreo e dois subsolos.

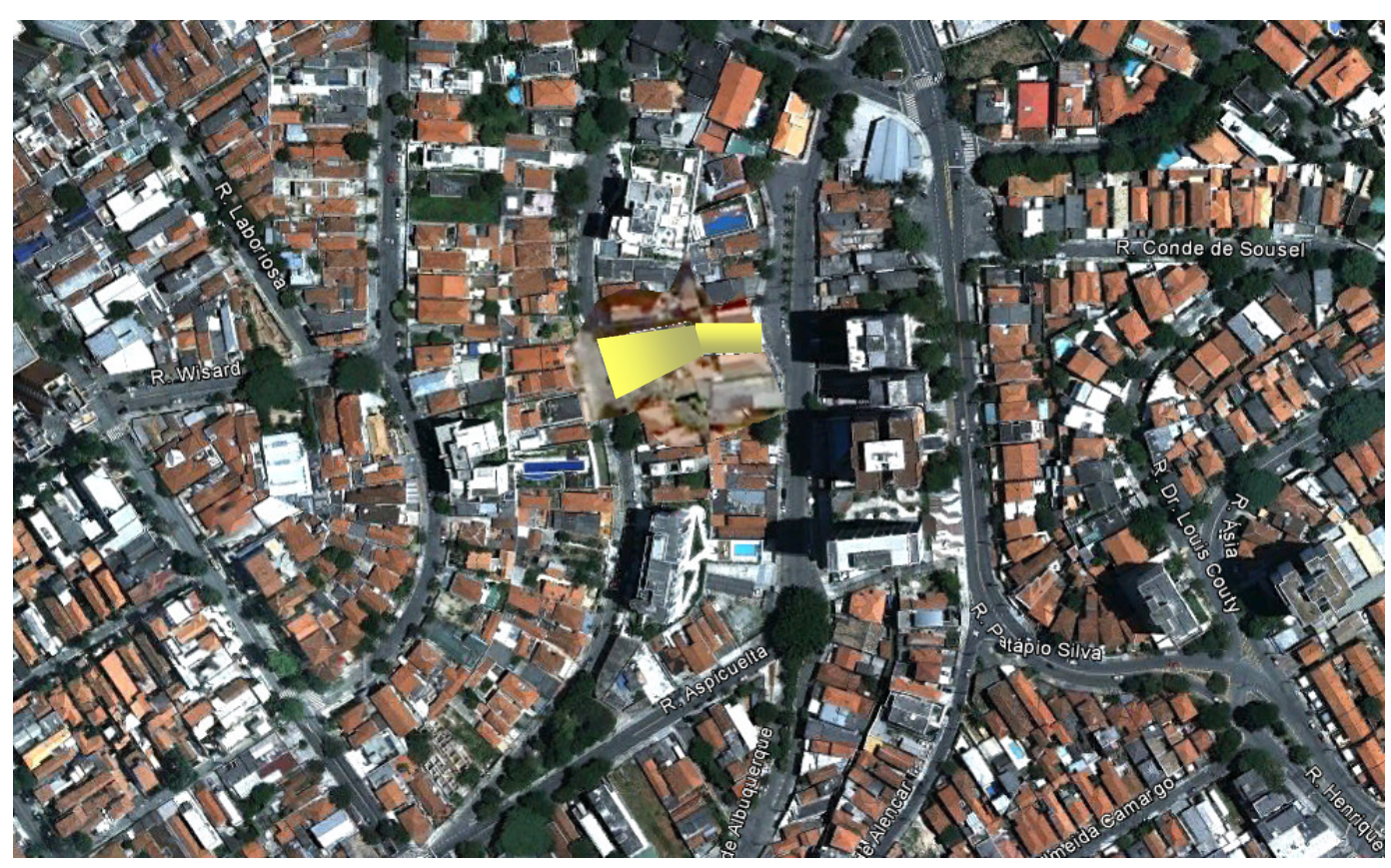

Figura 103: Mapa de localização - Fonte: Google Maps 2011 
Na ocasião, além da dupla Puntoni e Sodré, participou também da concepção do projeto o arquiteto Jonathan Davies. Segundo o arquiteto Álvaro Puntoni, a dedicação para o trabalho foi intensa. Na primeira apresentação, o projeto para o edifício estava praticamente pronto [Figuras 104 e 105]. Os arquitetos consideraram desde o início o lote complexo e o terreno em desnível para determinar a volumetria da obra. Nunca foi a intenção, criar um térreo falso e eliminar o terreno natural, mas sim tirar partido do mesmo.

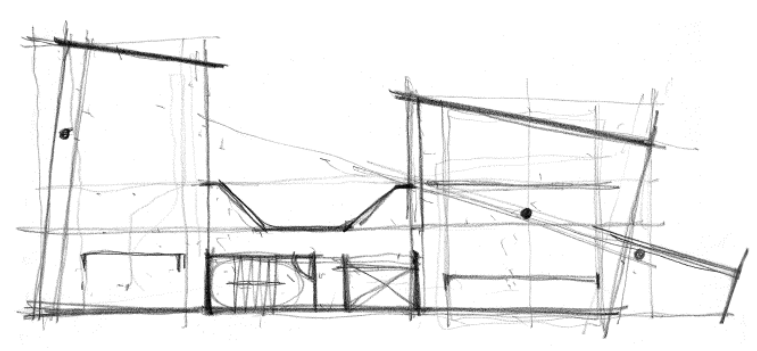

Figura 104 - Croqui 01 - Fonte: Acervo Grupo SP

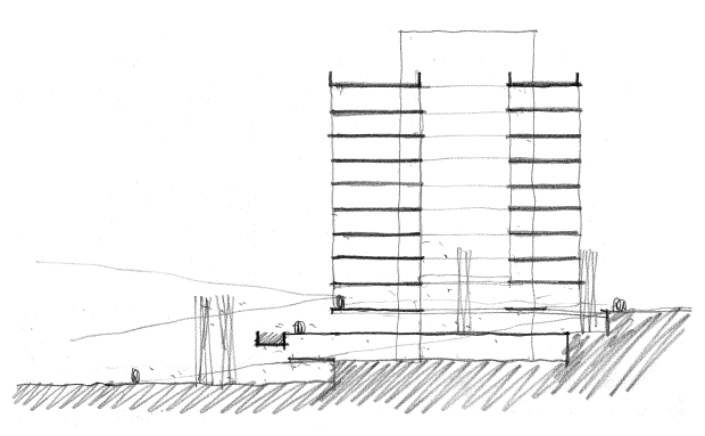

Figura 105 - Croqui 03 - Fonte: Acervo Grupo SP

O desenho foi conformado em dois blocos: um suspenso que abriga as unidades habitacionais e outro que segue o declive do terreno e recebe áreas comuns e estacionamento [Figuras 106 e 107]. O elemento que separa os dois blocos é uma laje elevada, como a flutuar sobre o terreno, acessada por uma passarela que parte da calçada [Figura 108]. Sobre esta passarela e próximo ao nível da rua, um painel com 2,80 m x 10 m composto de nove placas montadas in loco, do artista Andrés Sandoval [Figura109]. 

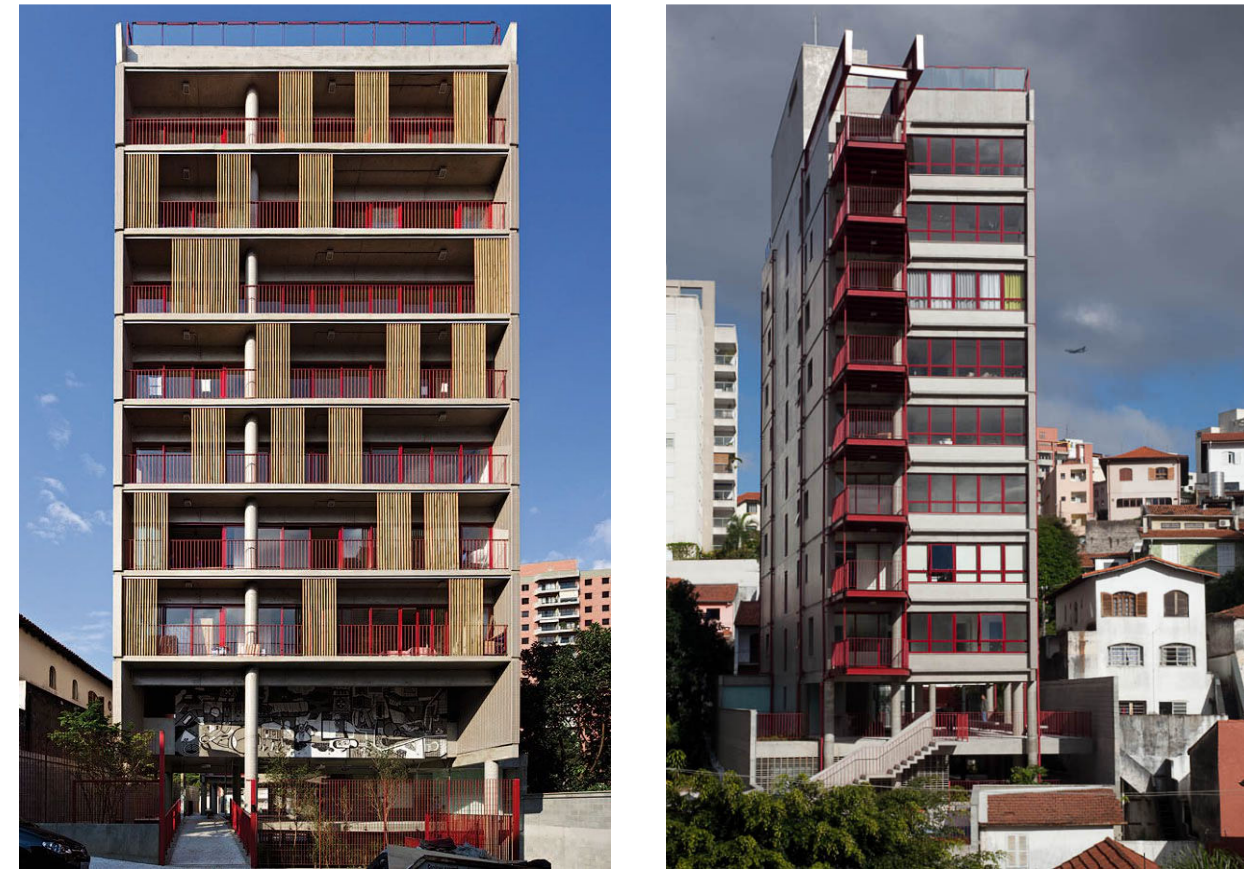

Figura 106 - Acesso Rua Simpatia Foto: Nelson Kon

Figura 107 - Acesso Rua Medeiros de Albuquerque
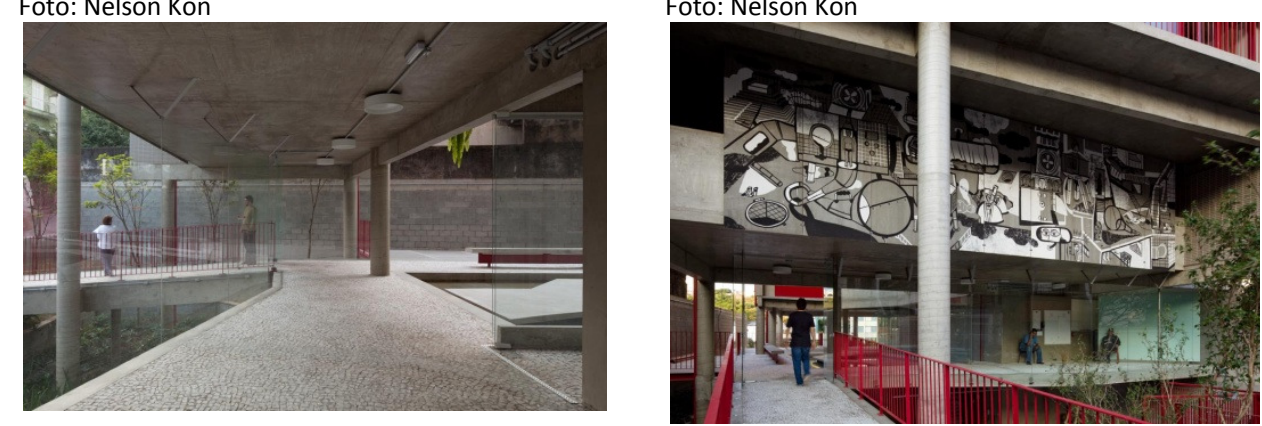

Figura 108 - Passarela e laje entre blocos Foto: Nelson Kon

Figura 109 - Painel Andrés Sandoval Foto: Nelson Kon 
A moradia foi planejada como as demais solicitadas por Zarvos: planta livre e flexibilidade total dos espaços para que cada usuário mais uma vez, possa adequar sua casa à suas necessidades. Para tanto, a laje foi deixada no osso - ou seja, sem contra piso. O mesmo tratamento foi dado no teto, sem forro [Figura 110]. Assim, cada morador tem liberdade total para escolher seus acabamentos. A planta também não possui divisórias internas fixas: usando divisórias de gesso acartonado, decide-se como quer repartir o espaço interior.

A flexibilidade da planta foi resolvida instalando as colunas de infraestrutura e hidráulica junto aos pilares, o que permite que as áreas molhadas possam estar em praticamente qualquer lugar da unidade [Figura 111]. Em duas das três fachadas de cada apartamento o morador pode, inclusive, escolher onde instalar suas janelas. Para isso, os arquitetos elegeram uma zona onde seria permitido existir aberturas e desenharam uma janela padrão que pode ser composta em módulos. O resultado da livre escolha dos moradores fica evidente nas fachadas, com o movimento aleatório das aberturas [Figuras 112 e 113]. 


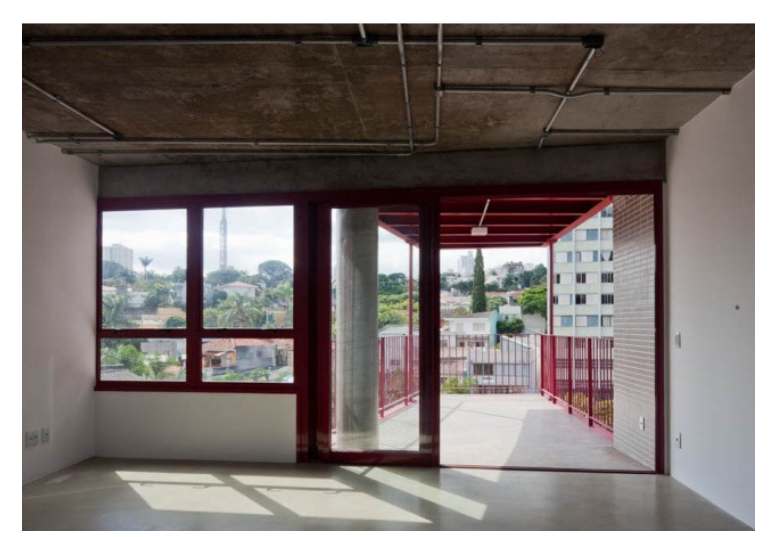

Figura 110 - Interno de uma unidade.

Foto: Nelson Kon

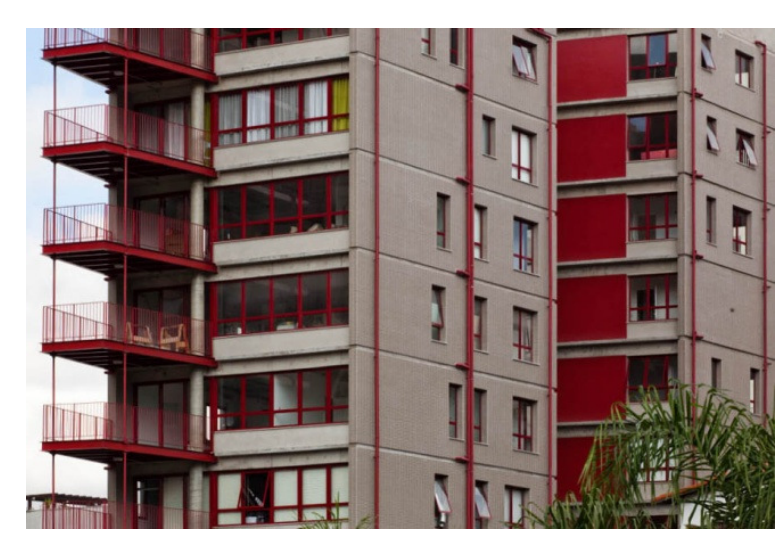

Figura 112 - Fachada lateral com aberturas definidas pelos moradores.

Foto: Nelson Kon

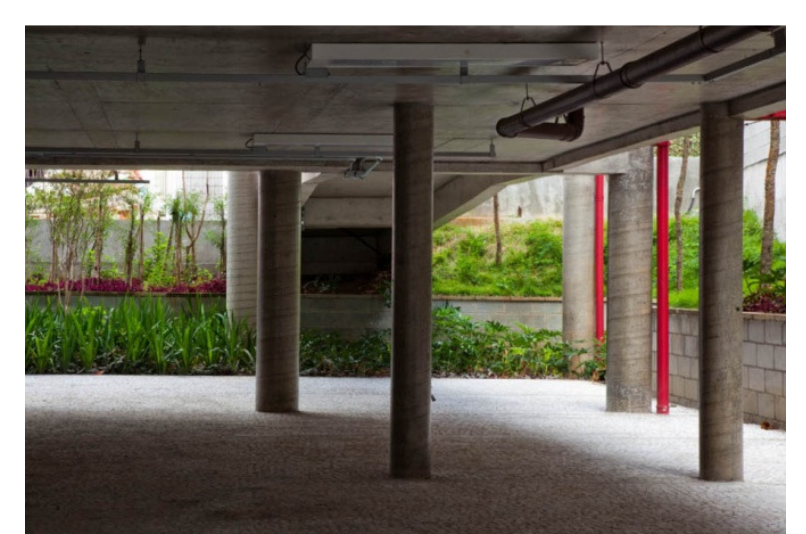

Figura 111 - Prumadas hidráulicas junto aos pilares Foto: Nelson Kon

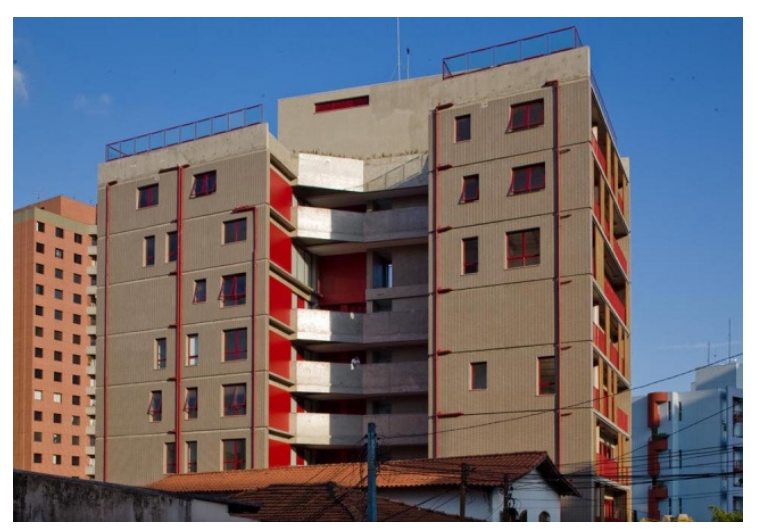

Figura 113 - Fachada lateral com aberturas definidas pelos moradores.

Foto: Nelson Kon 
As varandas na parte posterior do prédio também contribuem para o movimento da fachada. $\mathrm{Na}$ proposta original, teriam estrutura de concreto. Por questões de custo, os arquitetos reviram a solução e apresentaram uma nova proposta, desta vez, com estrutura metálica. A estrutura fica pendurada na parte superior por duas grandes vigas metálicas, e deixa livre a projeção da varanda no nível do térreo [Figuras 114 e 115].

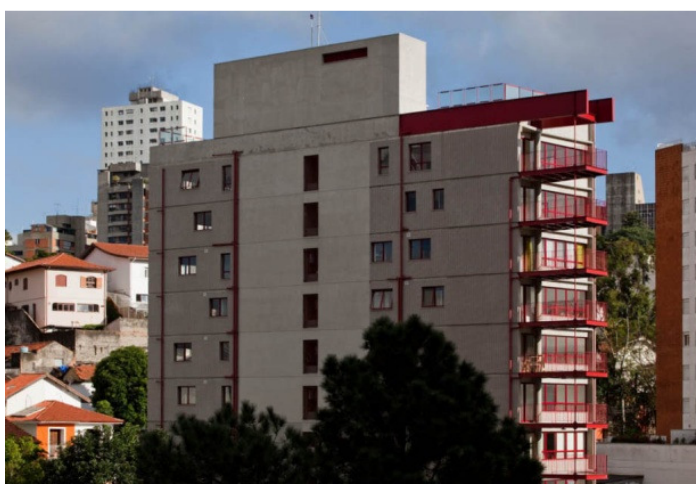

Figura 114 - Varandas metálicas - Estrutura de sustentação Foto: Nelson Kon

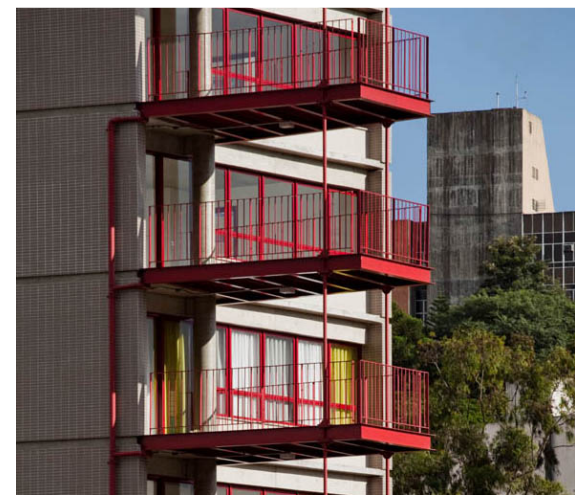

Figura 115 - Varandas metálicas Foto: Nelson Kon

O material especificado para a fachada foi o revestimento cerâmico - a empena voltada para o pátio interno recebeu pintura vermelha. O arquiteto conta escolheu a cerâmica por ser um material quase que auto-limpante. Já o mosaico português foi escolhido como material principal do piso para que a noção de externo, da calçada, adentrasse o edifício e tomasse conta das áreas 
de convívio, por isso o mosaico foi especificado para o espaço entre a porta do elevador e a porta dos apartamentos, um lugar aberto denominado pelos arquitetos de varanda de convivência

[Figuras 116 e 117].

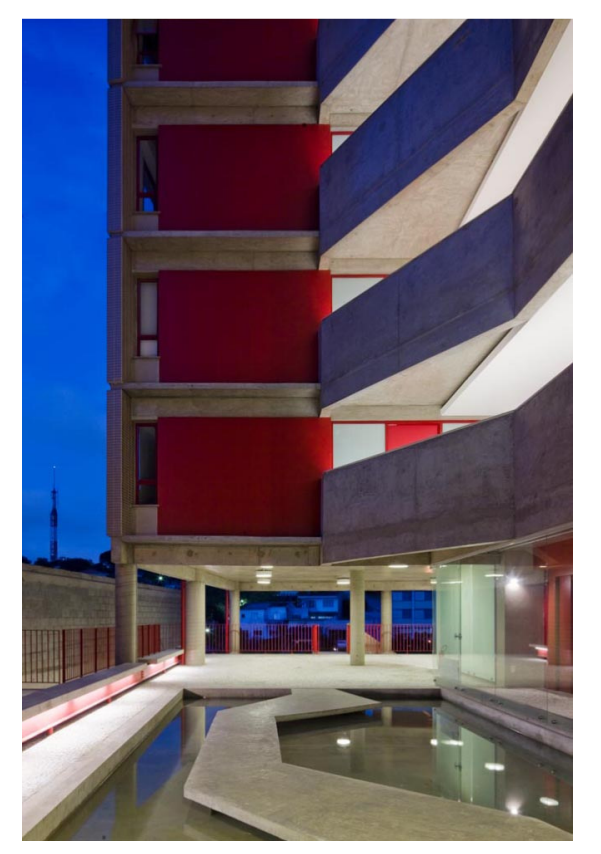

Figura 116 - Foto: Nelson Kon

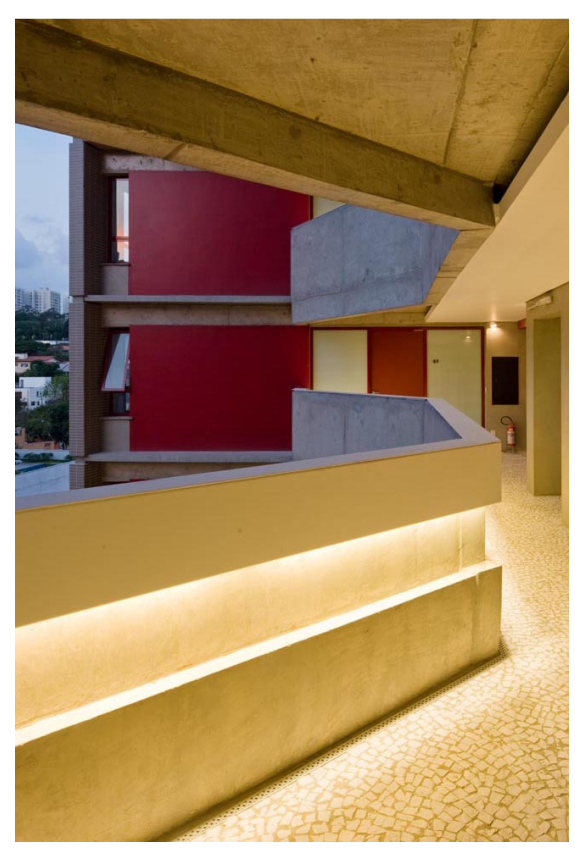

Figura 117 - Foto: Nelson Kon

Na busca incessante de conciliar os problemas impostos pelo sítio da melhor maneira possível, os arquitetos do Grupo SP resolveram encarar a questão do lote dos fundos, que neste caso faz frente para a rua Medeiros de Albuquerque. Este lote não podia se conformar como uma segunda entrada dos moradores por questões de logística e segurança. 
O que não raro vemos nestes casos é a subida de um grande muro de $6 \mathrm{~m}$ de altura, que torna inóspita a calçada para o trânsito de pedestres. O gesto foi recuar a grade de divisa deixando um alargamento da calçada, onde foi projetado um pequeno jardim com uma árvore e um banco. Este detalhe poderia até mesmo passar despercebido para quem olhasse com menos cuidado para o projeto, porém esta gentileza urbana, como definiu o grupo, com certeza não passará despercebida pela população que vive e transita pelo bairro da Vila Madalena - principalmente se atos como este começarem a servir de modelo e exemplo de como empreendimentos podem melhorar seu entorno imediato.

A paisagem do bairro da Vila Madalena é uma paisagem em transformação. Do alto do edifício da Rua Simpatia pode-se admirar um de seus vales, ainda com muitas áreas verdes, uma boa quantidade de casas e algumas construções mais altas. A grande marca ainda do bairro é que guarda uma escala própria: a da proximidade com a rua. João Sodré afirma que a obra se inseriu bem na paisagem e na escala das casas em volta, sem agredir a paisagem do bairro. 
PROJETO

SIMPATIA 236
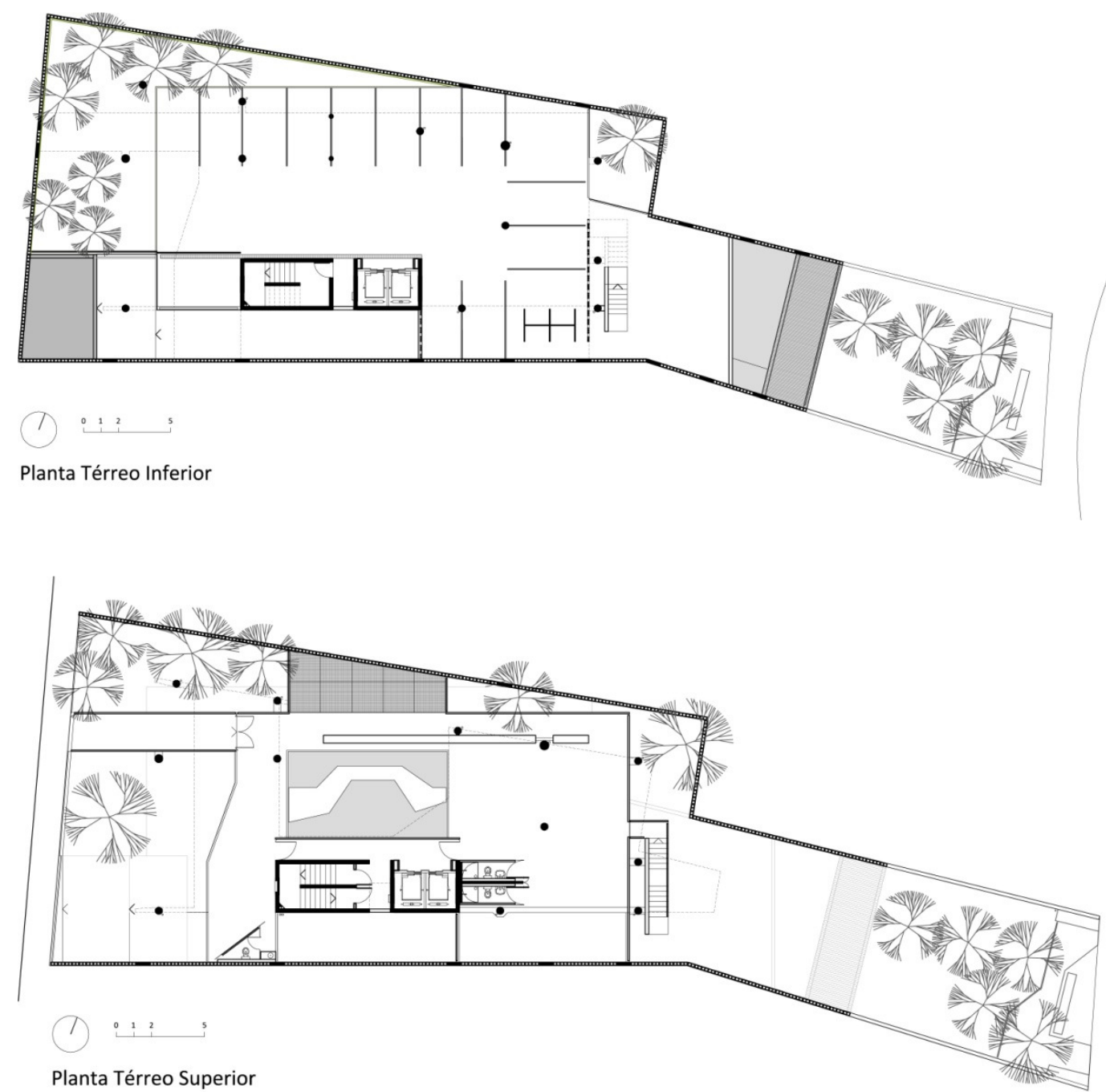


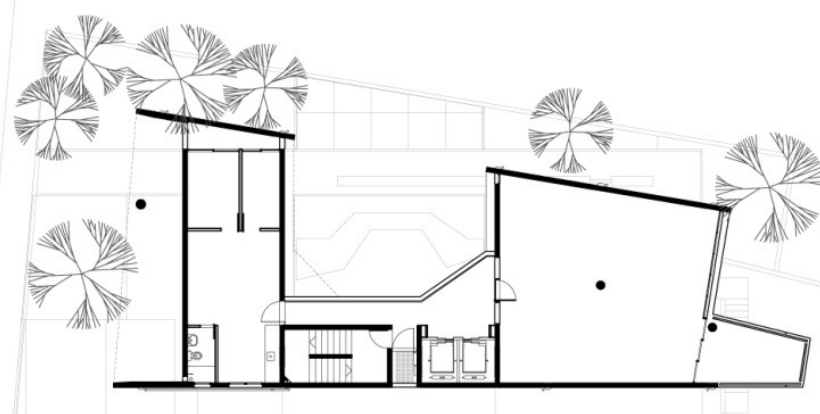

Planta Primeiro Pavimento
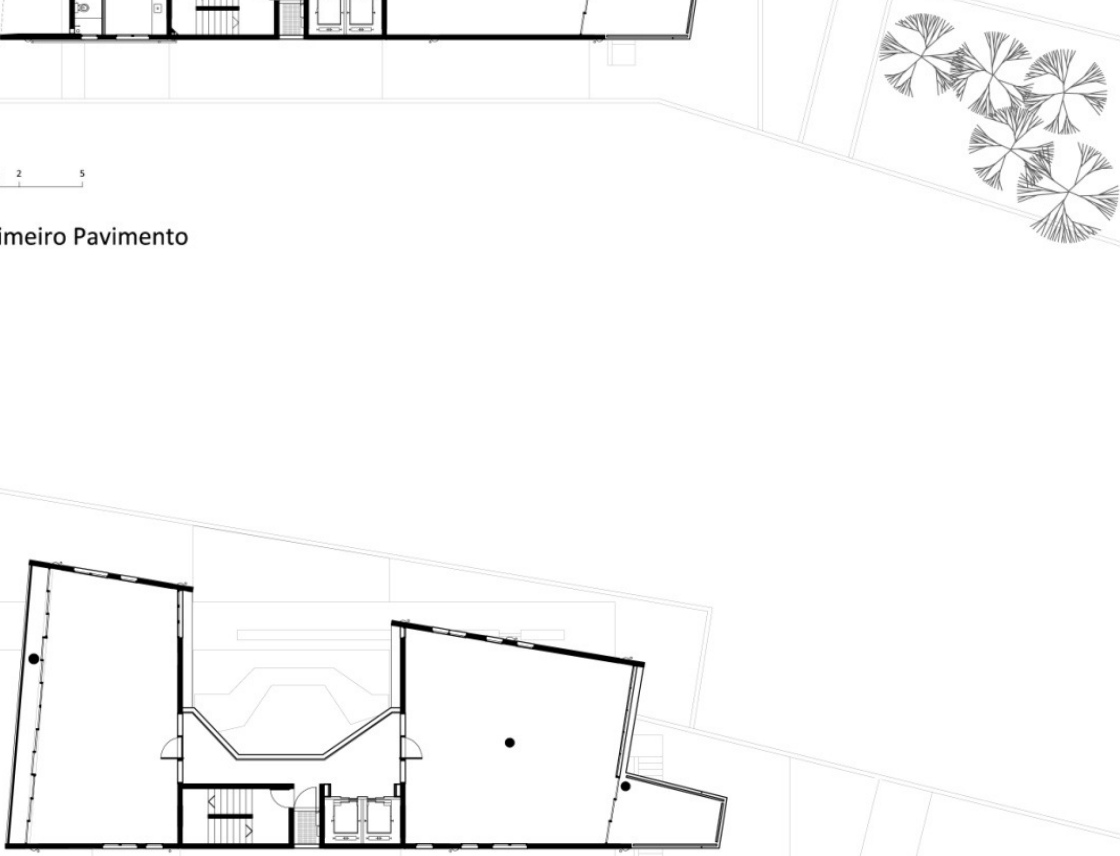

Planta Pavimento Tipo 


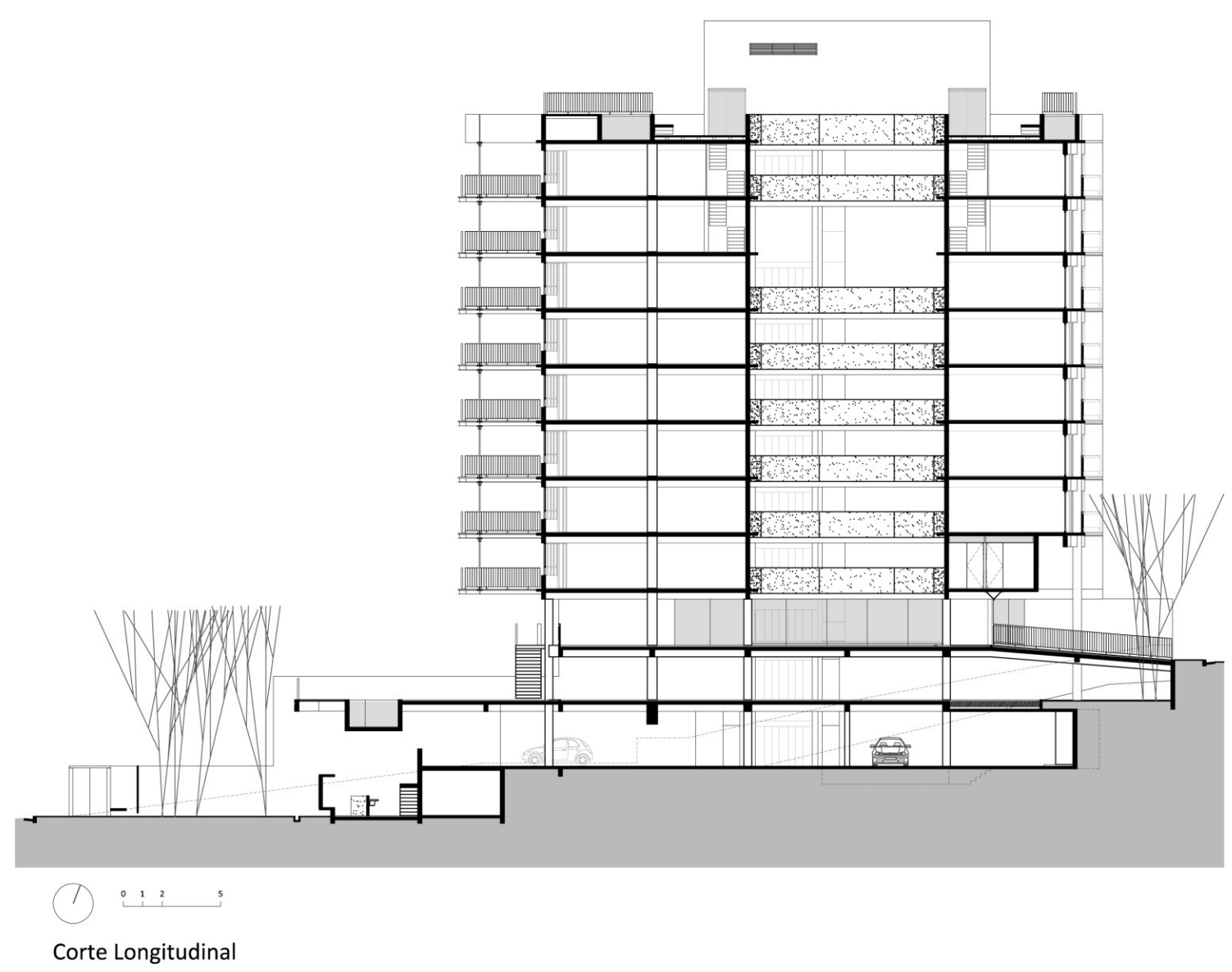




\section{EDIFÍCIO ITACOLOMI 445}

O projeto do Edifício Itacolomi de 2008 , até a presente data ainda em construção, procura reforçar o protagonismo do bairro de Higienópolis, abrindo-se para a sua paisagem construída e permitindo, simultaneamente, que o bairro inunde os espaços internos com generosas varandas dispostas nas fachadas anterior e posterior, que reforçam a relação da moradia com a paisagem do bairro [Figura 118]. Está na Zona Mista de Alta Densidade - ZM - 3b/01.

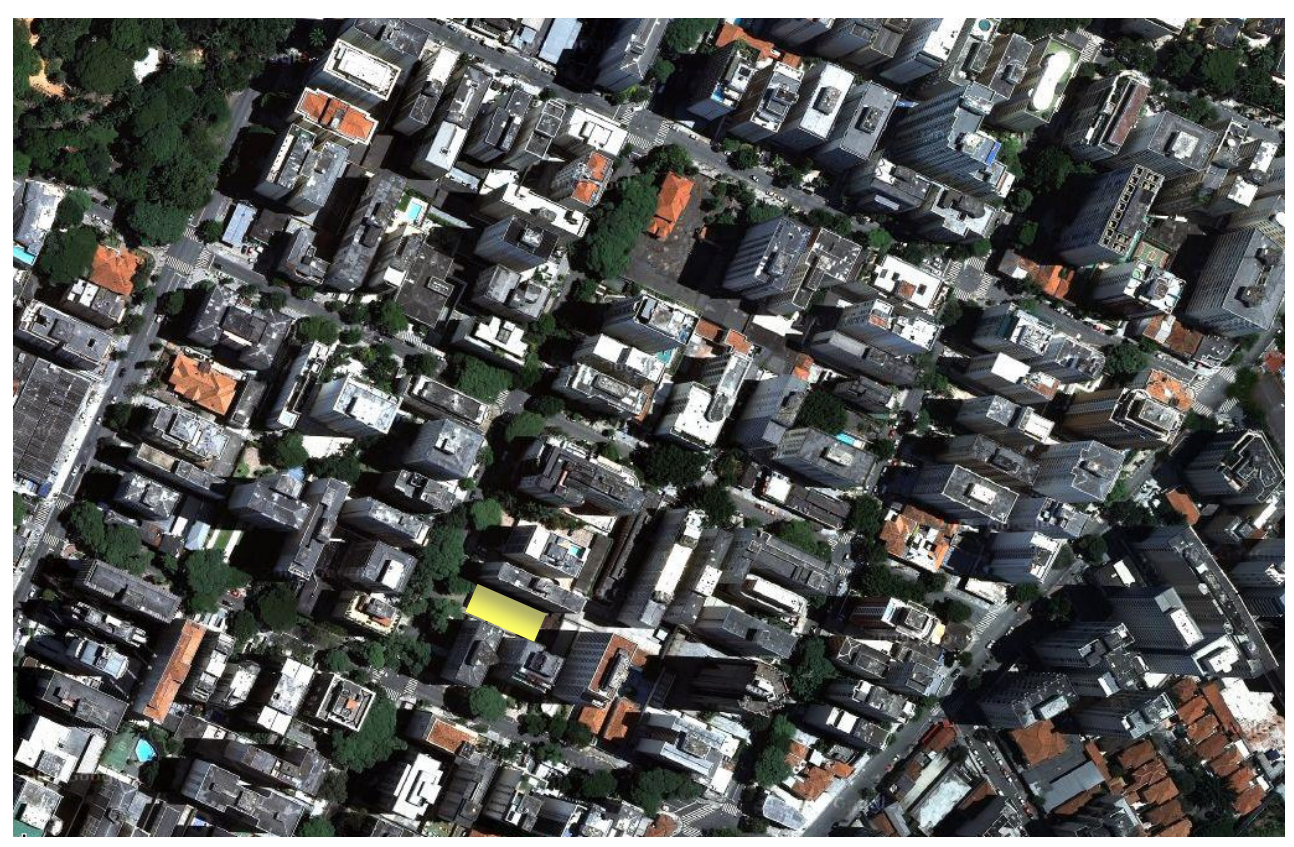

Figura 118: Mapa de localização - Fonte: Google Maps 2011 
Ocupando um terreno de $660 \mathrm{~m}^{2}$ serão construídas seis unidades que variam entre $314 \mathrm{~m}^{2} \mathrm{e}$ $561 \mathrm{~m}^{2}$. A distribuição do edifício se dará por dois subsolos, pavimento térreo, cinco pavimentos duplex e uma cobertura triplex [Figura119].

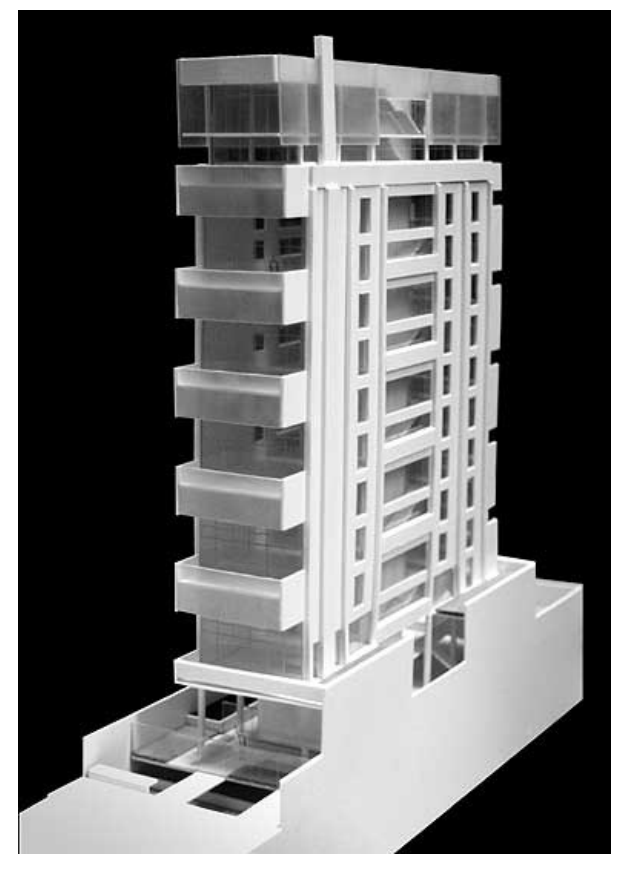

Figura 119 - Modelo - Fonte: Grupo SP

Envolto por uma trama de ladrilhos hidráulicos, o bloco de circulação vertical organiza o espaço, definindo um setor de conivência ligado à rua e outro mais íntimo, vinculado ao lado interno do lote. 
Nas fachadas anterior e posterior, generosas varandas reforçam a relação entre o apartamento e

a paisagem circundante, favorecendo visuais das copas das árvores e da cidade [Figuras 120 e 121].

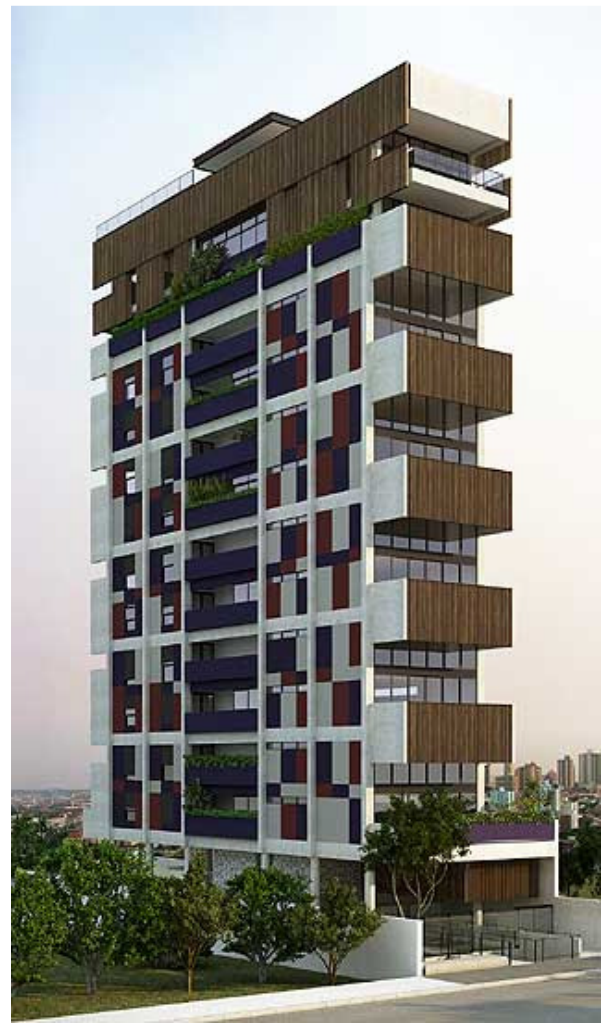

Figura 120 - Fonte: Grupo SP

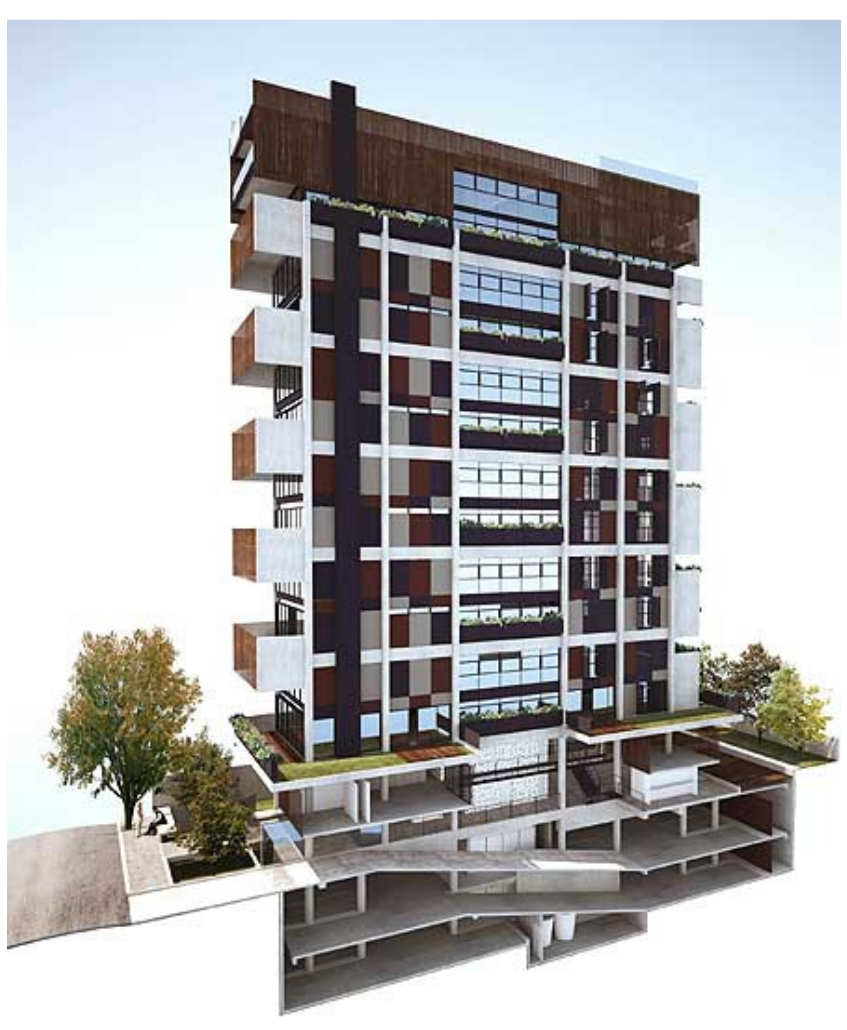

Figura 121 - Fonte: Grupo SP 
No térreo, o hall com pé direito duplo e a praça com piso de pedra portuguesa se estendendo até a calçada, evidenciam a preocupação novamente dos arquitetos em construir uma relação entre o edifício e seus arredores [Figura 122].

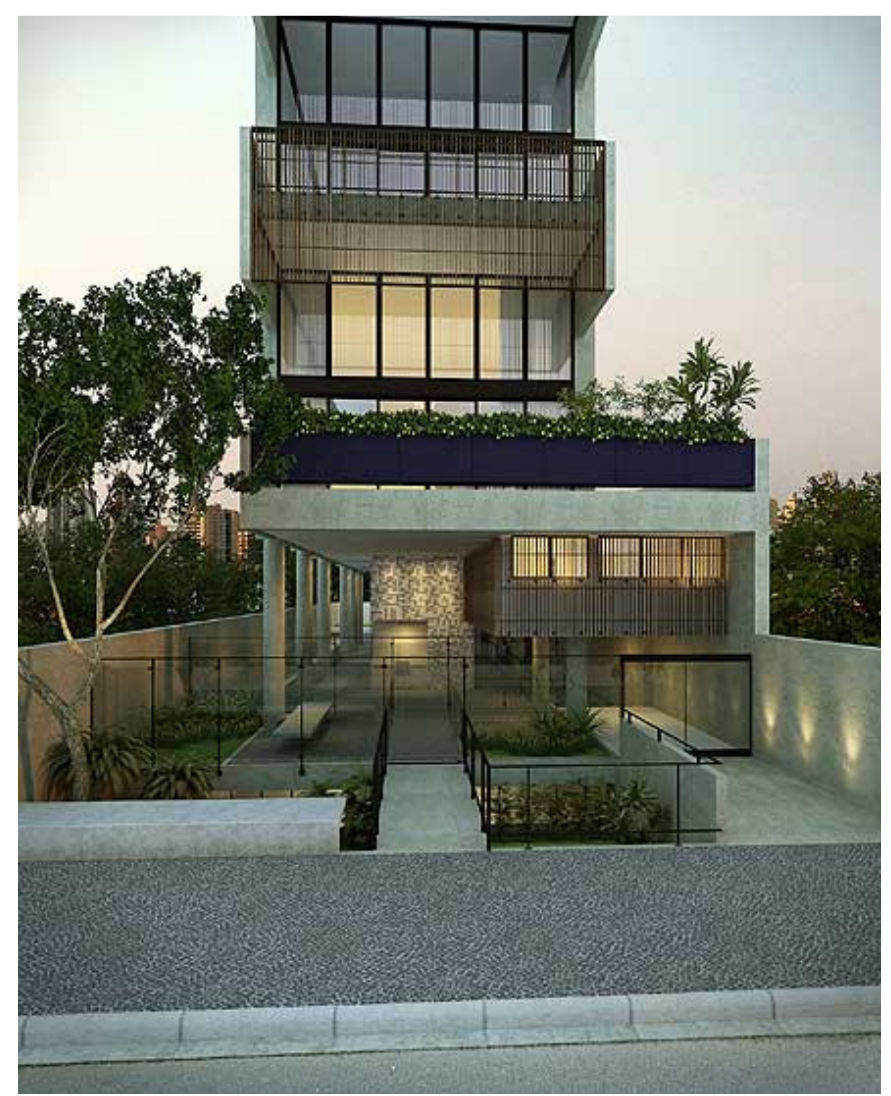

Figura 122 - Fonte: Grupo SP 
$\mathrm{Na}$ base do edifício, em um volume longitudinal revestido de madeira que paira sobre o espaço, foram implantadas a zeladoria e a sala de ginástica. Mais reservado, o espaço posterior abriga jardim, varanda comum e uma piscina de 25 metros de extensão. No coroamento, a estrutura principal de concreto armado é arrematada com uma estrutura complementar que conforma uma unidade habitacional especial, recuada em relação ao corpo principal. Liberto da altura dos edifícios contíguos, o volume mais transparente desfruta da paisagem circundante, ao mesmo tempo em que é protegido por um fechamento de madeira que o destaca do conjunto [Figura123]. Na cobertura, uma lamina d'água e um observatório da cidade.

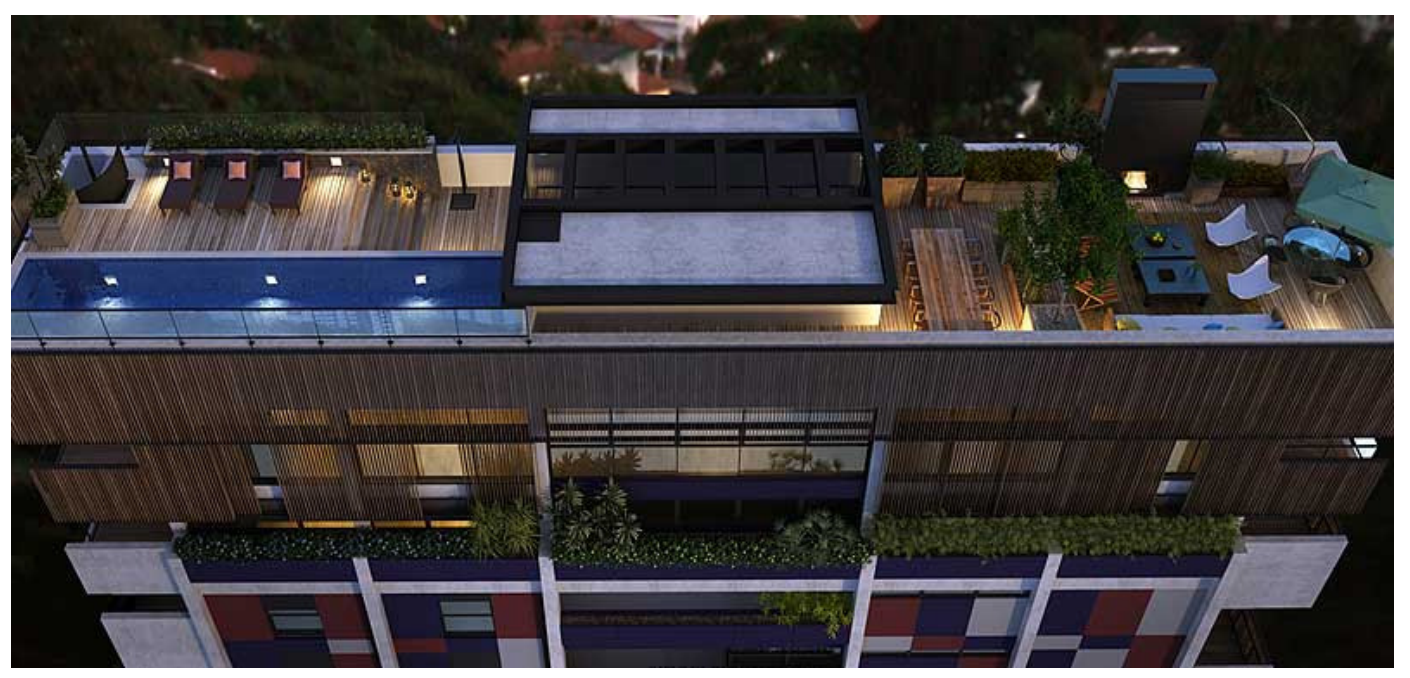

Figura 123 - Fonte: Grupo SP 
Este edifício, genérico na sua concepção e sistêmico por sua flexibilidade, é especifico por sua inserção e metafórico por travar diálogo com a história circundante.

O objetivo mais uma vez foi de criar unidades habitacionais flexíveis e abertas ou, nas palavras dos arquitetos, "vazios com pé-direito duplo que permitissem arranjos múltiplos de acordo com o modo de vida e tamanho da família". Para Jonathan Davies, um dos sócios do escritório na época do projeto afirma que foram criadas caixas vazias com infinitas possibilidades de ocupação.

Atendendo a solicitação do arquiteto João Sodré, o projeto será apresentado a seguir somente com as ilustrações eletrônicas, pois devido a alterações de equipe de obra, mudanças ocorrem neste momento da construção, impedindo a publicação dos desenhos oficiais que serão revisados.

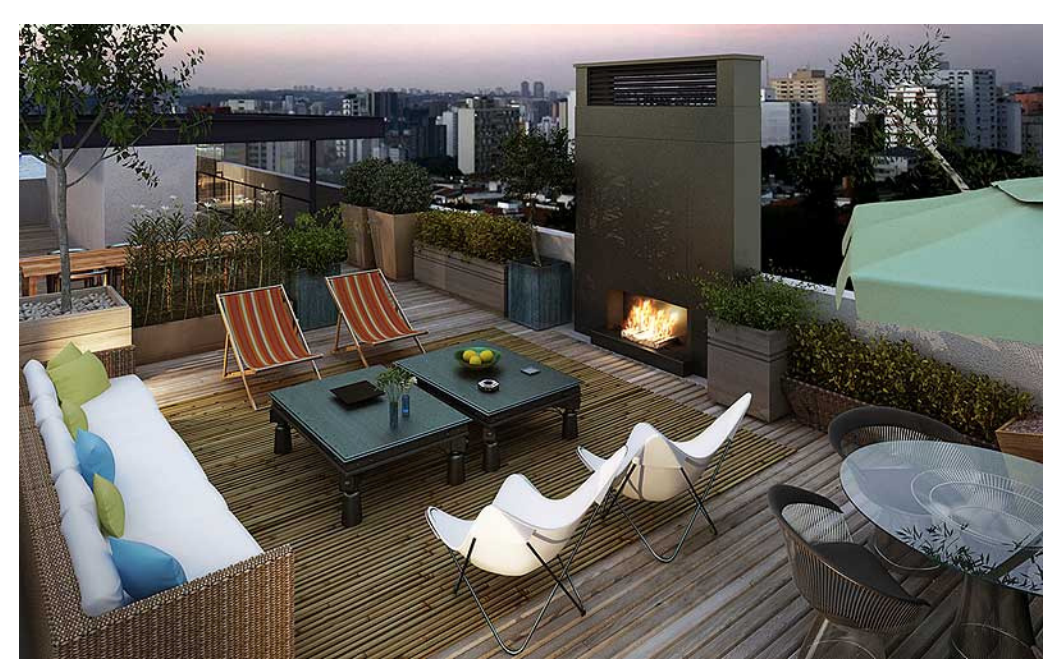

Figura 124 - Fonte: Grupo SP 


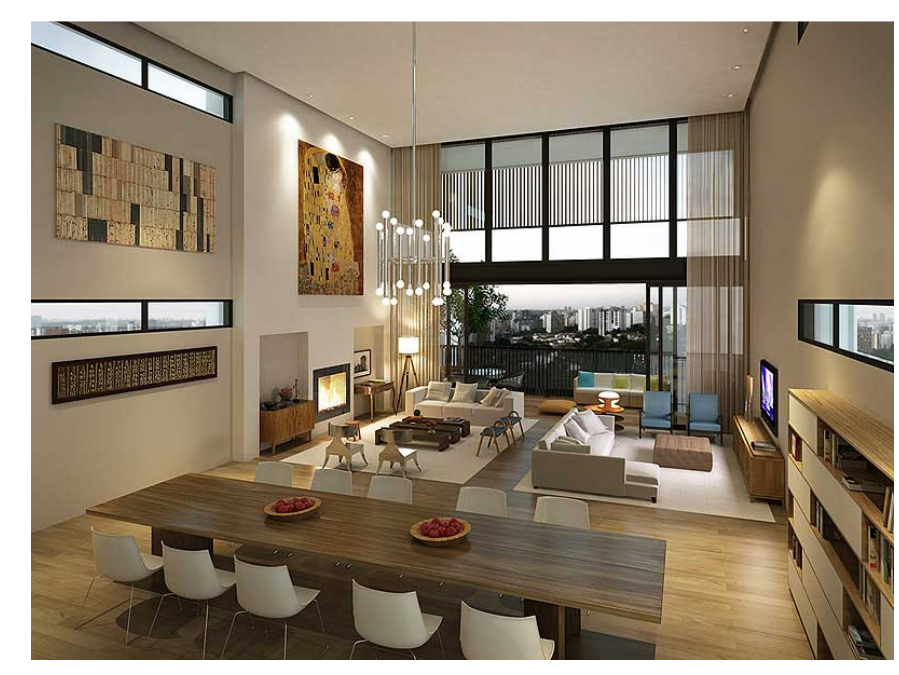

Figura 125 - Fonte: Grupo SP

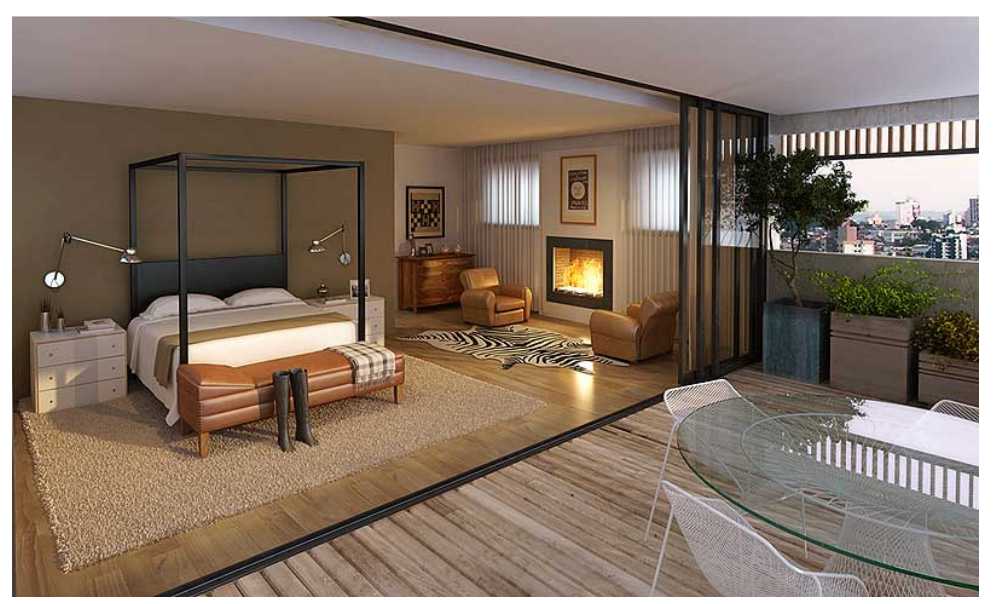

Figura 126 - Fonte: Grupo SP 


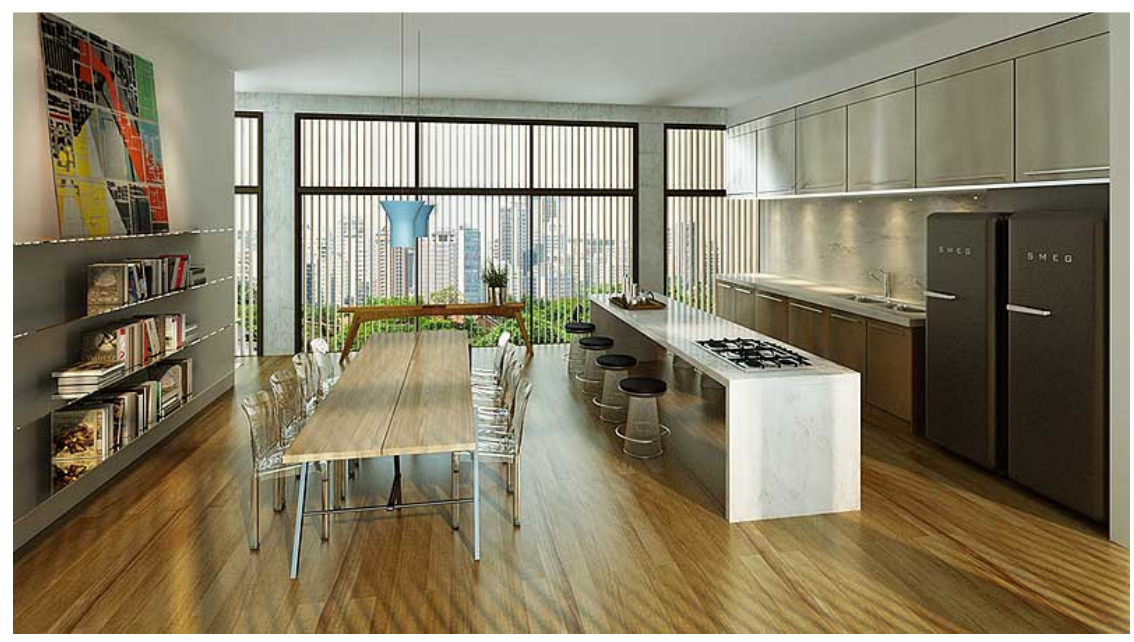

Figura 127 - Fonte: Grupo SP

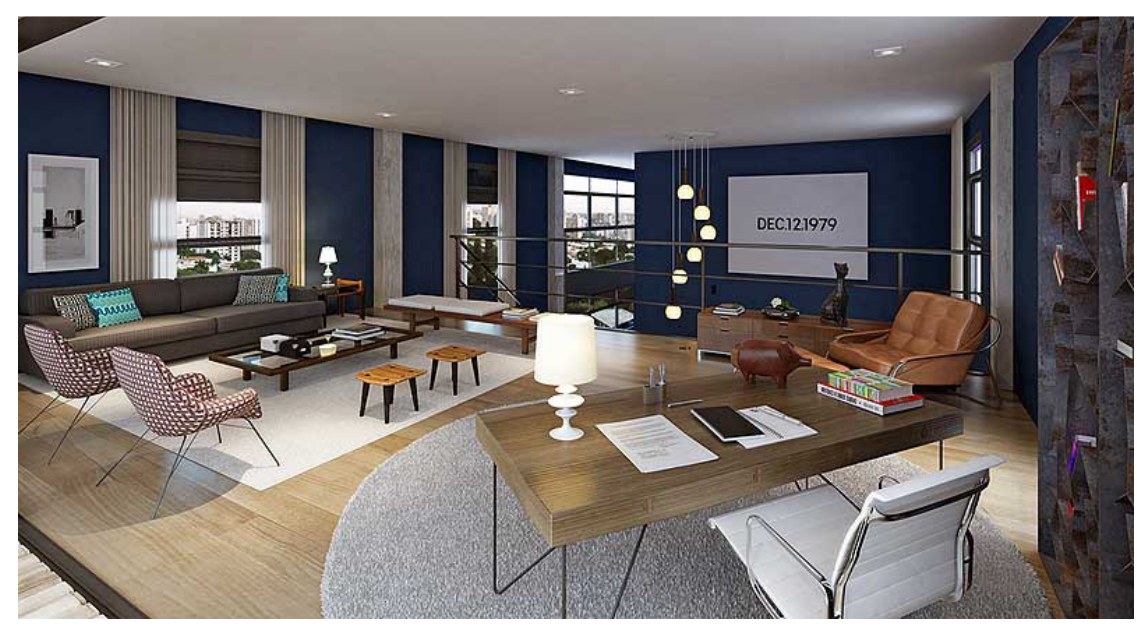

Figura 128 - Fonte: Grupo SP 
PROJETO

ITACOLOMI 445

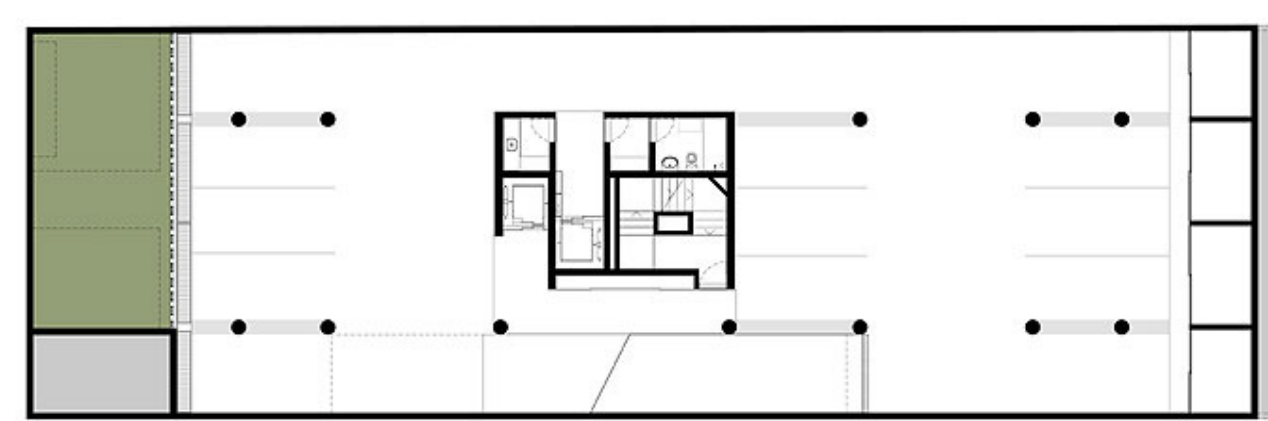

nn

Planta Subsolo

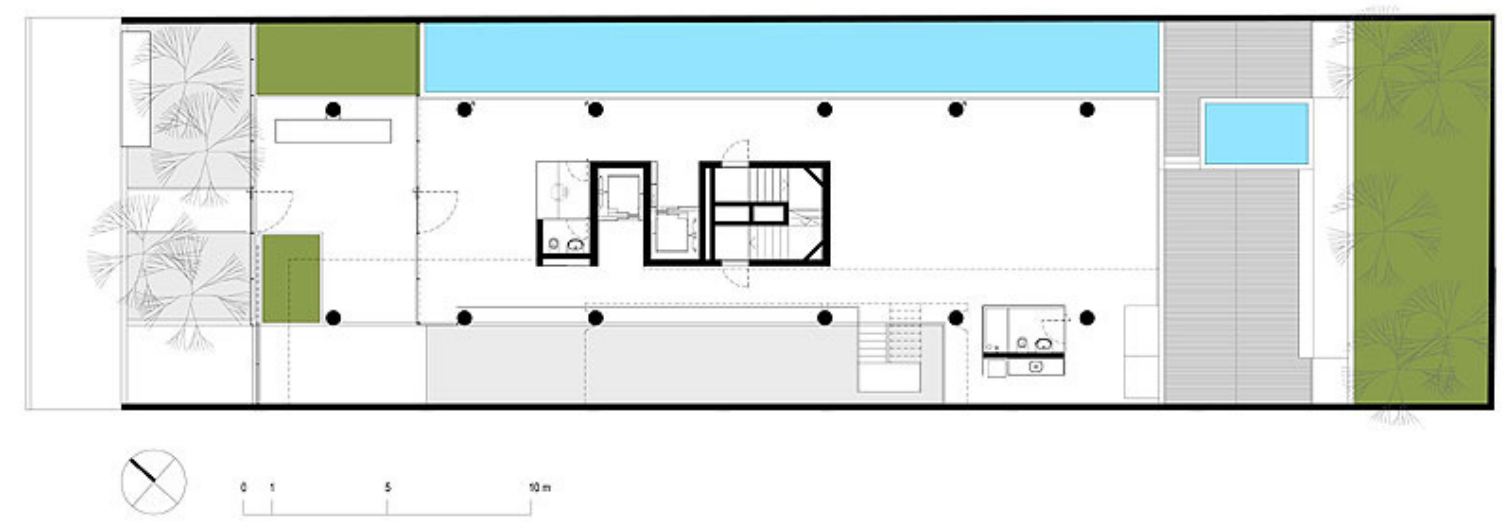

Planta Pavimento Térreo 

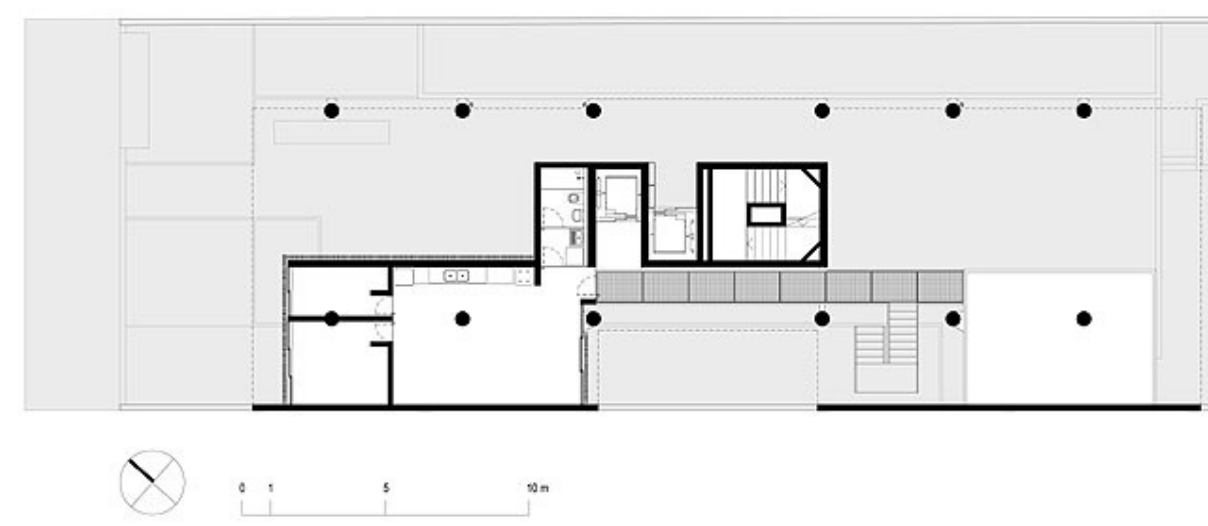

Planta Zeladoria e Sala de Ginástica
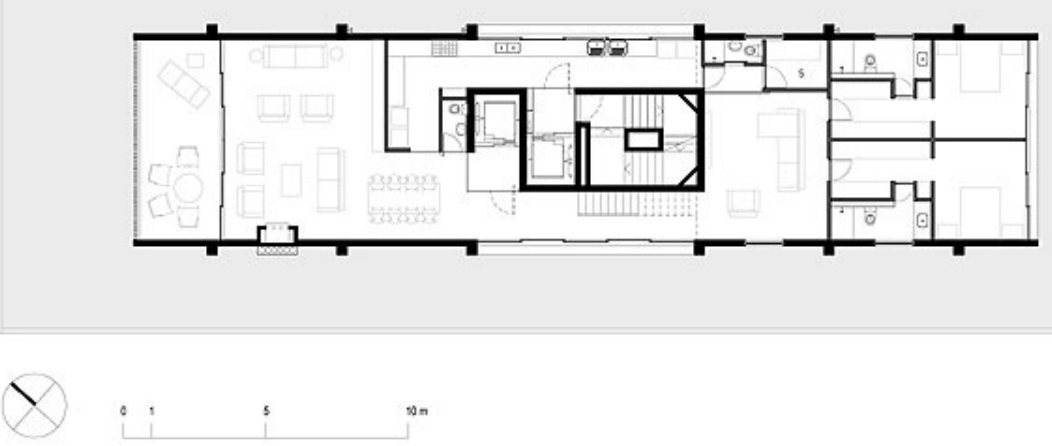

Planta Pavimento Tipo 

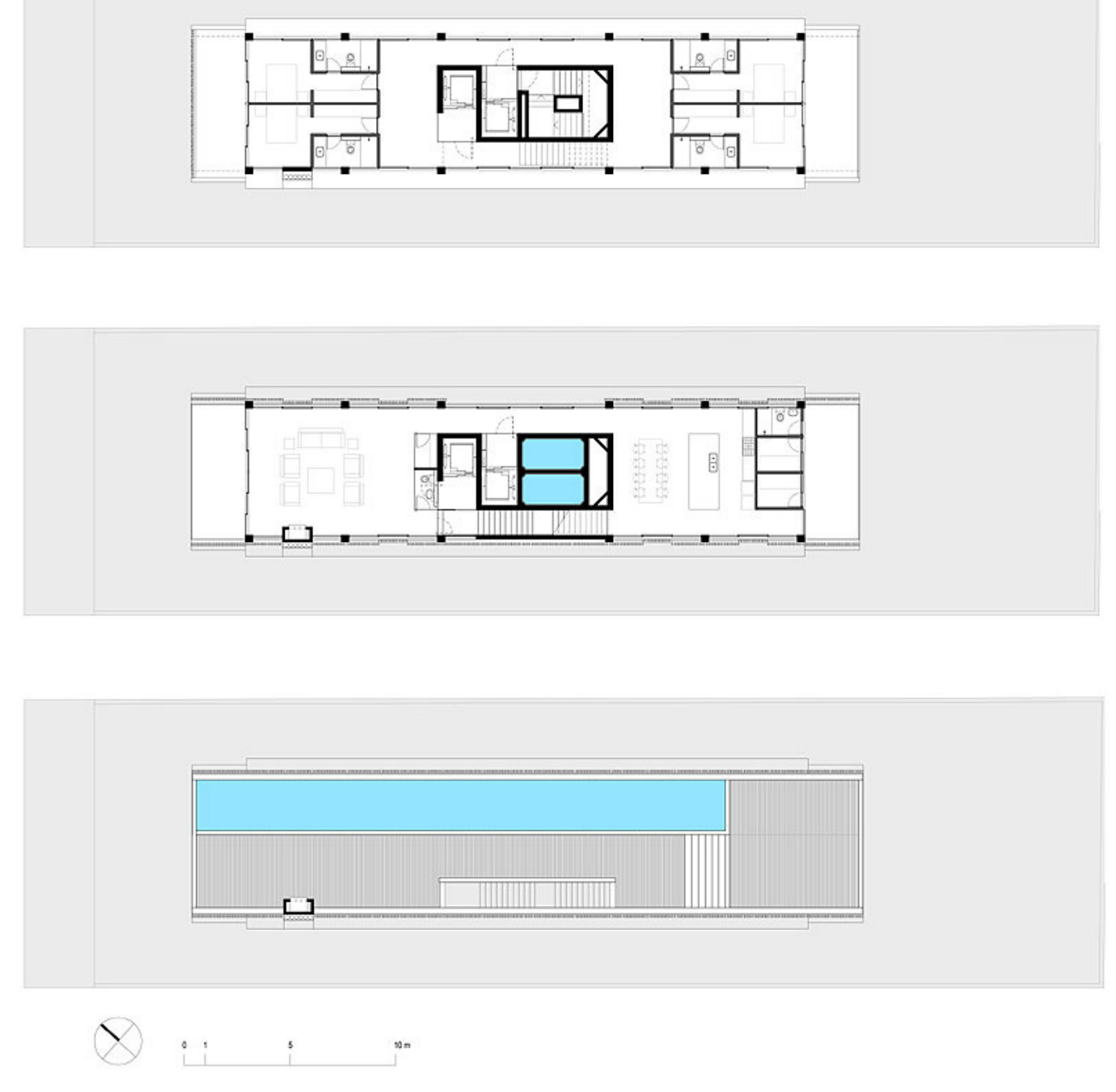

Planta Cobertura 


\section{CONSIDERAÇÕES FINAIS}

A construtora Formaespaço, em resposta a uma situação estabelecida na virada dos anos 70 do século 20, utilizou projetos de edifícios em série para tornar mais ágil a construção e o artifício de uma arquitetura diferenciada como estratégia de venda. A partir das possibilidades geradas pela própria construtora, foram adotadas diferentes soluções exemplificadas neste trabalho pelos projetos dos arquitetos - Abrahão Sanovicz, Eduardo de Almeida e Paulo Mendes da Rocha - revelando modos diferentes de se abordar um problema comum. Vale ressaltar, que apesar do pretexto inicial para a seleção de arquitetos e obras ter sido da construtora, prevaleceu nos projetos a orientação de cada arquiteto e seus respectivos compromissos com questões que comparecem ao longo de suas respectivas carreiras profissionais.

No conjunto do trabalho, as posições individuais de cada arquiteto complementaram-se entre si.

Atualmente, um conjunto cada vez maior de projetos como os citados neste trabalho reforça e amplifica a discussão dos edifícios residenciais privados nos meios de formação de opinião, especializado ou não, e em torno das noções de inovação, principalmente no que se refere à diversificação com produtos convencionais do mercado imobiliário. Quando se pensa em padrões convencionais do mercado imobiliário, deve-se observar que este é um mercado muito segmentado. Atribuir um paradigma único e homogêneo, opondo-lhe rupturas ou alternativas, acarreta o risco de não percebermos a escala em que eventualmente ocorrem.

Questões como a da inovação ou do modismo e da qualidade da arquitetura dificilmente são calculadas sem o balizamento mínimo dessa constelação do mercado imobiliário. 
Além disso, dentro de um mesmo segmento de valor, dado pela localização e padrão construtivo, apartamentos de mesma área ou com igual número de quartos apresentam diferenças: há uma crescente segmentação qualitativa nos produtos nas faixas superiores. E produtos que não se encaixam no formato usual da relação entre área, número de quartos e valor - ou seja, apartamentos de dois quartos com área acima da média da categoria, na mesma faixa de valor por metro quadrado; ou viceversa: apartamentos com a mesma área e número de quartos diferentes; e outros nos quais não é sequer definitivo o número de quartos, pois são flexíveis. Este é o caso dos produtos concebidos por Zarvos.

Os empreendimentos da Idea!Zarvos são focados a nichos específicos de mercado. Têm-se apartamentos de planta sugerida de duas suítes entre $100 \mathrm{~m}^{2}$ e $150 \mathrm{~m}^{2}$, mais frequentes, e de três suítes entre $200 \mathrm{~m}^{2}$ e $230 \mathrm{~m}^{2}$. Ou seja: superiores às médias das regiões valorizadas. A confrontação deles a um padrão geral, e mesmo ao de cada segmento convencionado, confunde sua especificidade, pois são sensivelmente distintos dos convencionais - principalmente no seu programa e formulação qualitativa de produto. Não indicam uma mudança do paradigma de mercado, no sentido de um novo modelo geral, mas atendem a uma especialização originada em

um segmento específico - no qual são arquitetonicamente distintos, nas condições de um movimento de inovação deste segmento. Ou seja, são resultados de uma inovação intrassegmento, de formação de um nicho, e não do conjunto do mercado. 
Por outro lado, expõem uma tendência geral de diferenciação do mercado, em múltiplas segmentações e, neste sentido, não se opõem a ele, mas ocorrem dentro dele. Não são a origem de uma inovação, mas têm atuação nela.

Podemos apontar como similaridades entre Formaespaço e Zarvos o fato de ambas atuarem na cidade de São Paulo, aliadas ao mercado imobiliário, buscando através de uma arquitetura de repertório, destaque na produção habitacional privada em diferentes períodos da história.

Em contrapartida, a principal diferença entre os períodos em questão, está no fato da construtora Formaespaço adotar os princípios e ideais difundidos pela Escola Paulista de Arquitetura unindo a racionalização e padronização dos materiais na realização de seus edifícios e a partir da reprodução em série, compor sua estratégia de venda enquanto hoje, num diferente momento socioeconômico, o edifício ganha o caráter de obra única, exclusiva. Não há uma ligação explícita a alguma corrente de pensamento; os projetos recentes adotam uma linguagem internacionalizada, apesar da maioria de seus criadores serem descendentes da antiga Escola Paulista. É evidente que a legislação local vigente, muito mais restritiva, e abusivo domínio das leis de mercado, também colaboram para uma maior diferenciação entre as produções dos períodos analisados. 
Ações empresariais criativas como a da Idea!Zarvos podem ter um efeito considerável neste processo, evitando que o tal contemporâneo se cristalize em fórmulas retóricas e, assim, aumente as opções dos consumidores e as oportunidades de trabalho dos arquitetos uma vez que, dentro do cenário da produção de apartamentos, o arquiteto é o que menos opina sobre o desenho das unidades. Tudo é decidido pela dupla incorporador-vendedor, sendo este último o que tem contato com o comprador e se atribui, por isso, o direito de definir padrões. O apartamento metropolitano, especialmente aquele produzido no mercado efervescente da metrópole paulista, ainda é hoje, muito mais um produto de estratégias de marketing do que um problema de arquitetura. Lamentável, uma vez que a habitação vertical privada é um dos grandes protagonistas na conformação da cidade. No entanto, o que a pesquisa aponta é que, de posse do conhecimento sobre o perfil real dos usuários, e disposto a rever toda a configuração espacial de unidades e edifícios, o profissional arquiteto pode vir a ocupar um lugar de destaque no processo. 
LIVROS:

ACAYABA, Marlene Milan \& FICHER, Silvia. Arquitetura moderna brasileira. São Paulo: Projeto, 1982. ACAYABA, Marlene Milan. Residências em São Paulo 1947 - 1975. São Paulo: Projeto, 1987. ANELLI, Renato et alii. Rino Levi. Arquitetura e cidade. São Paulo: Romano Guerra, 2001. ARANTES, Otília. O lugar da arquitetura depois dos modernos. São Paulo: Edusp, 2 ed., 1995. ARGAN, Giulio Carlo. História da arte como história da cidade. São Paulo. Martins Fontes, 1992. ARTIGAS, João Batista Vilanova. Caminhos da Arquitetura. São Paulo, Cosac \& Naify, 2004. BONDUKI, Nabil. Origens da habitação social no Brasil. São Paulo: Estação Liberdade, 1998. BRUAND, Yves. Arquitetura contemporânea no Brasil. São Paulo: Perspectiva, 1981.

BRUNA, Paulo. Os primeiros arquitetos modernos. São Paulo: Edusp, 2010

CAVALCANTI, Lauro. Quando o Brasil era Moderno: Guia de Arquitetura 1928 - 1960. Rio de Janeiro. Aeroplano. 2001.

CAVALCANTI, Lauro, CORRÊA DO LAGO, André. Ainda Moderno? Arquitetura Brasileira Contemporânea. Rio de Janeiro: Nova Fronteira, 2005. 
COMAS, Carlos Eduardo. Moderna (1930 a 1960). In: MONTEZUMA, Roberto (Org.). Arquitetura Brasil 500 anos: uma invenção recíproca. Recife: Universidade Federal de Pernambuco, 2002.

CURTIS, William J.R. Arquitetura Moderna desde 1900. Porto Alegre. Bookman. 2008.

FERRAZ, Geraldo - Warchavchik e a introdução da nova arquitetura no Brasil: 1925 a 1940. MASP, São Paulo, 1965

FRAMPTON, Kenneth. História Crítica da Arquitetura Moderna. São Paulo. Martins Fontes. 1997.

JACOBS, Jane. Morte e vida de grandes cidades. São Paulo: Martins Fontes, 2000.

KAMITA, João Masao. Vilanova Artigas. São Paulo: Cosac Naify, 2000.

KOOLHAAS, Rem. Delirious New York: a retroactive manifesto for Manhattan. New York, The Monacelli Press, 1994. [Nova York Delirante: um manifesto retroativo para Manhattan. São Paulo, Cosac \& Naify, 2008

KOOLHAAS, Rem. Três textos sobre a cidade. 0 problema do grande, A cidade genérica e espaço-lixo. Barcelona, Ed. Gustavo Gili, 2010.

KOPP, Anatole. Quando o moderno não era um estilo e sim uma causa. São Paulo: Nobel; Edusp, 1990.

LEMOS, Carlos A.C. - Arquitetura Brasileira. São Paulo, Melhoramentos / Edusp, 1970. 
LEMOS, Carlos A.C. - Cozinhas, etc.... São Paulo, Perspectiva, 1978.

LEMOS, Carlos A.C. - Alvenaria Burguesa. São Paulo, Nobel, 1989.

LEMOS, Carlos A.C. - Casa Paulista. São Paulo. Edusp, 1999.

MILHEIRO, Ana Vaz; NOBRE, Ana Luisa; WISNIK, Guilherme. Coletivo - 36 projetos de arquitetura contemporânea paulista. São Paulo. Cosac \& Naify. 2006.

MINDLIN, Henrique Ephim. Arquitetura Moderna no Brasil. Rio de Janeiro. Aeroplano, 2000.

MONEO, Rafael. Inquietação Teórica e Estratégia Projetual. São Paulo. Cosac \& Naify. 2008.

MONTANER, Josep Maria. Arquitetura e Crítica. 2 ed. Barcelona: Gustavo Gili, 2007.

MONTANER, Josep Maria. Depois do Movimento Moderno: arquitetura da segunda metade do século XX . Barcelona: Gustavo Gili, 2001.

NESBITT, Kate [org]. Uma Nova Agenda para a Arquitetura: Antologia Teórica [1965-1995]. São Paulo. Cosac Naify. 2006.

REIS FILHO, Nestor Goulart - Quadro da arquitetura no Brasil. São Paulo, Perspectiva, 1978.

ROSSI, Aldo. Arquitetura da cidade. São Paulo: Martins Fontes, 1995.

SEGAWA, Hugo. Arquiteturas no Brasil 1900-1990. São Paulo. Edusp. 1998. 
SEGRE, Roberto. América Latina fim de milênio: raízes e perspectivas de sua arquitetura. São Paulo: Studio Nobel, 1991.

SOUZA, Maria Adélia A. - A Identidade da Metrópole: a verticalização em São Paulo. São Paulo, EDUSP, 1994.

VENTURI, Robert. Complexidade e contradição em arquitetura. 2. ed. São Paulo: Martins Fontes, 2004.

WARCHAVCHIK, Gregori - "Il futurismo" publicado em 14 de junho no jornal da colônia italiana II Picolo e republicado com o título "Acerca da Arquitetura Moderna" em 1 de novembro, no jornal Correio da Manhã, Rio de Janeiro in XAVIER, Alberto (org.) Arquitetura Moderna Brasileira: Depoimentos de uma Geração. São Paulo, Editora Pini/ABEA/FVA, 1987.

WISNIK, Guilherme. Estado Crítico: à deriva nas cidades. São Paulo. Publifolha. 2009.

XAVIER, Alberto; LEMOS, Carlos; CORONA, Eduardo - Arquitetura Moderna Paulistana. São Paulo, Pini, 1983.

XAVIER, Alberto (org.). Arquitetura Moderna Brasileira: Depoimento de uma geração. 2. Ed. São Paulo: Cosac \& Naify, 2003.

ZEIN, Ruth. O lugar da crítica. Ensaios oportunos de arquitetura. Porto Alegre: Editora Ritter dos Reis São Paulo: ProEditores, 2002.

ZEVI, Bruno. Saber Ver a Arquitetura. São Paulo. Martins Fontes. 1996. 


\section{DISSERTAÇÕES, TESES E ARTIGOS PUBLICADOS:}

ABASCAL, Eunice Helena Sguizzardi. Cidade e arquitetura contemporânea: uma relação necessária. Artigo publicado no portal Vitruvius - seção Arquitextos 066 no 338. Novembro 2005.

Cí́lCO, L. A. A importância do projeto no desenvolvimento de espaço das áreas privativas dos apartamentos. In: IX ENTAC - ENCONTRO NACIONAL DE TECNOLOGIA DO AMBIENTE COSNTRUÍDO. 2002, Foz do Iguaçu, Paraná. Anais. São Paulo, 2002. Acervo Biblioteca Secovi SP

COSTA, A. A imagem da Arquitetura e a arquitetura da Imagem: uma investigação acerca da construção dos discursos na produção do espaço urbano. Dissertação de mestrado apresentada à FAU USP. 2002.

FONSECA, Nuno de Azevedo. A Arquitetura do Mercado Imobiliário e seu processo de produção na cidade de São Paulo. Tese de doutorado apresentada à FAUUSP. 2000.

FONSECA, A. C. P. A promoção imobiliária privada e a construção da cidade de São Paulo - 1970/2002. Tese de doutorado apresentada à FAUUSP. 2004.

HOESEL, P; SOMEKH, N. A verticalização em São Paulo: apontamentos metodológicos. CADERNOS DE PÓS-GRADUAÇÃo EM ARQUITETURA E URBANISMO. São Paulo: Editora Mackenzie, v. 1, n. 1, p. 9-30, 2001.

IMBRONITO, Maria Isabel. Três Edifícios de Habitação para a Formaespaço: Modulares, Gemini e Protótipo. Dissertação de Mestrado apresentada à FAUUSP. 2003. 
KUSHPIL, Eneida. O Edifício Vertical e a Cidade: Imagens da Modernidade sob o Olhar do Espaço

Público. Tese de Doutorado apresentada à FAUUSP. 2008

LEITÃO, E. S; FORMOSO, C. T. Análise do comportamento de compra do consumidor de imóveis residenciais - estudo de casos: apartamentos novos de 2 e 3 dormitórios. In: VIIIENTAC ENCONTRO NACIONAL DE TECNOLOGIA DO AMBIENTE CONSTRUÍDO. 2000, Salvador, Anais, São Paulo, 2002. Acervo Biblioteca Secovi SP

LOUREIRO, C.; AMORIM, L. Dize-me teu nome, tua altura e onde moras e te direi quem és: estratégias de marketing e a criação da casa ideal - parte 1. ARQUITEXTOS: Periódico Mensal de Textos de Arquitetura, Campinas, no 281, fevereiro de 2005. Disponível em www.vitruvius.com.br/arquitextos/arq000/esp281.asp.

LUCCAS, Luis Henrique Haas. Arquitetura Contemporânea no Brasil: da crise dos anos setenta ao presente promissor. ARQUITEXTOS: Periódico Mensal de Textos de Arquitetura, Campinas, no 101, outubro de 2008. Disponível em http://vitruvius.es/revistas/read/arquitextos/09.101/99

MAHFUZ, Edson da Cunha. Sociedad Y Consumo. Arquitecturas Silenciosas. Artigo publicado na revista ARQ no62. Chile.

PETRUCCI, Celso. “Balanço do Mercado Imobiliário: 2001 - 2010 A Década da Retomada” - Relatório SECOVI SP. Acervo Biblioteca Secovi SP

RIGHI, R.; CASTRO, L. G. R. O produto imobiliário e a arquitetura contemporânea em São Paulo. In: V ENCONTRO DA LARES - LATIN AMERICAN REAL ESTATE SOCIETY. 2005, São Paulo. Anais. São Paulo, 2005. Acervo Biblioteca Secovi SP 
SANTOS, M. B. P.; ORNSTEIN, S. W. São Paulo: lançamentos 2002 e perspectivas futuras, a qualidade do projeto habitacional sob a ótica dos principais agentes envolvidos na produção do empreendimento. . Brasil - Belo Horizonte, MG. 2003. 12p. III WORKSHOP BRASILEIRO DE GESTÃO DO PROCESSO DE PROJETO NA CONSTRUÇÃO DE EDIFÍCIOS, 3., 2003, Belo Horizonte. Acervo Biblioteca Secovi SP

SOMEKH, Nadia. Cidade Vertical e o Urbanismo Modernizador em São Paulo - 1920 a 1939. Tese de Doutorado apresentada à FAUUSP. 1994.

SPADONI, Francisco. Quase Contemporâneo: questões para a arquitetura dos anos 60 aos anos 80, a forma, a figura e a técnica. Dissertação de Mestrado apresentada à FAUUSP. 1997.

SPADONI, Francisco. Dependência e resistência: transição na arquitetura brasileira nos anos de 1970 e 1980. Artigo publicado no portal Vitruvius - seção Arquitextos 102. Novembro 2008. Artigo baseado na Tese de Doutorado intitulada: A transição do Moderno. Arquitetura Brasileira na década de 1970. FAUUSP - 2004. Publicado em Arquiteses 1: tempo, cidade e arquitetura. São Paulo, Annablume/FUPAM, 2007.

TRAMONTANO, Marcelo Novos Modos de Vida, Novos Espaços de Morar: Paris, São Paulo,

Tokyo, FAU-USP. São Paulo 1998. Tese de Doutorado.

TRAMONTANO, Marcelo Habitação Moderna: a construção de um conceito. São Carlos, EESC/USP, 1993. 
VILARIÑO, Maria do Carmo. Habitação Verticalizada na cidade de São Paulo dos anos 30 aos anos 80. Dissertação de Mestrado. Faculdade de Arquitetura e Urbanismo. Universidade de São Paulo. São Paulo. 1997.

VILLA, S. Apartamento Metropolitano: habitações e modos de vida na cidade de São Paulo. 2002. Dissertação (Mestrado em Arquitetura e Urbanismo) - Universidade de São Paulo / Escola de Engenharia de São Carlos/ Faculdade de Arquitetura e Urbanismo, São Carlos.

VILLA, S. - Morar em apartamentos: a produção dos espaços privados e semi-privados nos edifícios ofertados pelo mercado imobiliário no século XXI em São Paulo e seus impactos na cidade de Ribeirão Preto. Critérios para Avaliação Pós-Ocupação. FAU-USP. São Paulo, 2008. Tese de Doutorado.

\section{PERIÓDICOS:}

Revista ARQ. n.79 - dezembro 2011. Edifício Aimberê. P.44- 49. Chile. Ediciones ARQ

Revista ARQ. n.79 - dezembro 2011. Edifício Simpatia. P.50-55. Chile. Ediciones ARQ

Revista AU. Ano 24 n.183 - junho 2009. Edifício 4x4 por Simone Sayegh . P.40 - 47. São Paulo. Editora Pini.

Revista AU. Ano 25 n.196 - julho 2010. Edifício Aimberê 1749 por Ledy Valporto Leal . P.34 - 41 . São Paulo. Editora Pini. 
Revista AU. Ano 26 n.201 - dezembro 2010. Edifício Ourânia por Giovanny Gerolla. P.44 - 49. São Paulo. Editora Pini.

Revista AU. Ano 26 n.202 - janeiro 2011. Entrevista com Daniel Libeskind por Renato Faria . P.58 - 60. São Paulo. Editora Pini.

Revista AU. Ano 26 n.203 - fevereiro 2011. Edifício Fidalga 727 por Simone Sayegh. P.24- 29. São Paulo. Editora Pini.

Revista AU. Ano 26 n.205 - abril 2011. Edifício residencial Montevidéu por Silvana Maria Rosso. P. 26 31. São Paulo. Editora Pini.

Revista AU. Ano 26 n.205 - abril 2011. Interseção - “Arquitetos e o mercado imobiliário” por Eduardo Andrade de Carvalho. P. 74 - 75. São Paulo. Editora Pini.

Revista AU. Ano 26 n.207 - junho 2011. Entrevista com Otávio Zarvos por Cleide Floresta. P. 66 - 68. São Paulo. Editora Pini. 
Revista AU. Ano 26 n.207 - junho 2011. Edifício Fidalga 772 por Theodoro Holck. P. 46 - 53. São Paulo. Editora Pini.

Revista AU. Ano 26 n.207 - junho 2011. Edifício Simpatia por Ursula Troncoso. P. 54 - 61. São Paulo. Editora Pini.

Revista AU. Ano 26 n.207 - junho 2011. Interseção Especial - “O empresário criativo e a arquitetura equilibrista" por Luiz Mauro do Carmo Passos. P. 69 - 71. São Paulo. Editora Pini.

Revista AU. Ano 27 n.218 - maio 2012. Arquitetos Empreendedores - "Três Edifícios Residenciais Geridos por Arquitetos". P. 50 - 65. São Paulo. Editora Pini.

Revista DOMUS n.958 - maio 2012. “L’Idea di Zarvos”por Roberto Zancan. P. 56 - 65. Milão. Editora Domus.

Revista MONOLITO. Ano I n. 2 - 2011. Andrade e Morettin. São Paulo. Editora Monolito.

Revista MONOLITO. Ano II n. 11 - 2012. Jovens Arquitetos. São Paulo. Editora Monolito.

Revista PROJETO n.141 - 1991. "Obviedade e mediocridade" por Hugo Segawa. P. 63. São Paulo. Arco Editorial.

Revista PROJETO DESIGN n.241 - março 2000. “O edifício invisível e a cidade inexistente" por Fernando Serapião. São Paulo. Arco Editorial. 
Revista PROJETO DESIGN n.275 - janeiro 2003. “Pós-Modernismo lá e cá” por Francisco Spadoni. São Paulo. Arco Editorial.

Revista PROJETO DESIGN n.290 - abril 2004. “Os edifícios-fantasmas e seus ornamentos delinqüentes." por Fernando Serapião. P. 1. São Paulo. Arco Editorial.

Revista PROJETO DESIGN n. 353 - julho 2009. Seção Entrelinhas - "Mudanças de Ares", por Fernando Serapião. P. 68 - 79. São Paulo. Arco Editorial.

Revista PROJETO DESIGN n. 353 - julho 2009. Edifício 4x4. P. 54 - 61. São Paulo. Arco Editorial.

Revista PROJETO DESIGN n. 353 - julho 2009. Edifício Aimberê 1749. Por Adlison Melendez. P. 62 - 67. São Paulo. Arco Editorial.

Revista Summa+. N. 113 - fevereiro 2011. Habitação Coletiva - "A Matemática da Torre Ideal”, por Pablo Güibaldes. P. 20 - 31. Buenos Aires / São Paulo. Donn Editorial e Ação Editorial.

Revista Summa+. N. 120 - março 2012. Habitação Coletiva - Edifício Fidalga 727. P. 70-75. Buenos Aires / São Paulo. Donn Editorial e Ação Editorial.

Revista Summa+. N. 120 - março 2012. Habitação Coletiva - Edifício Fidalga 772. P. 76-81. Buenos Aires / São Paulo. Donn Editorial e Ação Editorial.

Revista Summa+. N. 120 - março 2012. Habitação Coletiva - Edifício Simpatia. P. 82-87. Buenos Aires / São Paulo. Donn Editorial e Ação Editorial. 


\section{WEB SITES CONSULTADOS:}

www.andrademorettin.com.br

www.arquiteturabrutalista.com.br, coord. Prof. Dra. Ruth Verde Zein, FAU-Mackenzie

www.axpe.com.br

www.arcoweb.com.br

www.embraesp.com.br

www.gruposp.arq.br

www.ideazarvos.com.br

www.maxhaus.com.br

www.movimentoum.com.br

www.movimentoum.com.br/movimentoum/aimbere1749/

www.movimentoum.com.br/fidalga727/

www.movimentoum.com.br/movimentoum/simpatia236/

www.prefeitura.sp.gov.br 
www.revistaau.com.br

www.secovi.com.br

www.stan.com.br

www.triptyqueblog.blogspot.com

www.vitacon.com.br

http://exame.abril.com.br/inovacao/noticias/maxhaus-toda-casa-tem-cara-dono-578447 